UNIVERSIDADE DE SÃO PAULO

FACULDADE DE FILOSOFIA, LETRAS E CIÊNCIAS HUMANAS

DEPARTAMENTO DE GEOGRAFIA

PROGRAMA DE PÓS-GRADUAÇÃO EM GEOGRAFIA HUMANA

\title{
Tem gente na roça! \\ O Modo de Vida Camponês em Ribeirão Branco - SP
}

\author{
Lucinei Paes de Lima \\ Dissertação apresentada ao Programa de Pós- \\ Graduação em Geografia Humana do \\ Departamento de Geografia da Faculdade de \\ Filosofia, Letras e Ciências Humanas da \\ Universidade de São Paulo, para obtenção do \\ título de Mestre em Ciências. Área de \\ concentração: Geografia Humana
}

Orientadora: Prof ${ }^{a}$. Dr ${ }^{\mathrm{a}}$. Valéria de Marcos

$\underline{\text { Versão corrigida }}$

São Paulo

2017 
Autorizo a reprodução e divulgação total ou parcial deste trabalho, por qualquer meio convencional ou eletrônico, para fins de estudo e pesquisa, desde que citada a fonte.

Catalogação na Publicação

Serviço de Biblioteca e Documentação

Faculdade de Filosofia, Letras e Ciências Humanas da Universidade de São Paulo

L732t Lima, Lucinei Paes de

Tem gente na roça! O Modo de Vida Camponês em

Ribeirão Branco - SP / Lucinei Paes de Lima ;

orientadora Valéria de Marcos. - São Paulo, 2017.

$189 \mathrm{f}$.

Dissertação (Mestrado) - Faculdade de Filosofia, Letras e Ciências Humanas da Universidade de são Paulo. Departamento de Geografia. Área de concentração: Geografia Humana.

1. Campesinato. 2. Comunidade rural. 3. Cultura popular. 4. Geografia agrária. 5. Tomate. I. Marcos, Valéria de, orient. II. Título. 
Para as camponesas e os camponeses de Ribeirão Branco. 



\section{Agradecimentos}

À minha orientadora Valéria pela ousadia do "sim" que transformou a minha vida. Obrigada pela atenção desmedida e por me nortear durante toda a pesquisa. $\mathrm{O}$ seu compromisso para com a causa do campesinato é encorajador.

Ao Ariovaldo Umbelino e Larissa Bombardi que fizeram parte da minha banca de qualificação e contribuíram valiosamente para este trabalho.

Ao meu filho Cauã, que me faz enxergar o mundo de outras maneiras e me fez mergulhar no universo das escolas democráticas. Obrigada pelos abraços calorosos e pelas massagens nos dias em que eu mais precisei.

Ao Fernando, com quem compartilho a minha vida, que é também o meu primeiro e melhor leitor: sua influência e apoio a cada etapa foram essenciais. Sem ele, eu não teria tido a energia necessária para levar este projeto.

Aos meus pais, meus primeiros professores, que me ensinaram que era preciso lutar por um mundo melhor sempre. Vocês me inspiram todos os dias!

Às minhas irmãs, mulheres de luta!, pelo carinho, compreensão e apoio em tudo o que fiz na vida. Vocês possibilitaram que eu fosse a primeira da família a entrar na universidade.

Aos meus sobrinhos, Ana, Pedro, Duda, Gabriel, Luiza e Beatriz, pela delícia de ser tia.

À família do meu companheiro, dona Isaura e seu Vivaldo pelo apoio, compreensão e carinho, e ao Leonardo pelo exemplo de menino estudioso.

Aos meus afilhados, José, Gabriel e Benício, que eu possa lhes garantir uma boa história para contar e que passemos mais tempo juntos.

À todas as mulheres que cuidaram do meu filho para que eu pudesse trabalhar, fazer militância e estudar, sem vocês nada disso seria possível: Rosângela, Meire, Graziele, Lilian, Letícia e Daniela. Minha eterna gratidão!

À paróquia Bom Jesus e à Prefeitura de Ribeirão Branco pela atenção dedicada minha pesquisa. Ao Padre Cícero (in memoriam), que foi uma importante fonte de informações.

A todos que me concederam as entrevistas e enriqueceram esse trabalho - sobretudo, às camponesas e camponeses de Ribeirão Branco.

Ao Prof. Dr. Ailton Luchiari (in memoriam) que tanto insistiu para que eu aprendesse a manipular o GPS e indicasse os pontos visitados desta pesquisa.

À minha amiga, prima e companheira Sueli de Lima Almeida, por me auxiliar com as coordenadas e lançamento delas nos mapas de indicação da área da pesquisa. 
À minha amiga Malu, que topou ler com tanta atenção o meu trabalho.

Ao meu amigo Felipe El Debs, grande mestre internacional de xadrez, pelo abstract.

Aos médicos Marcos Broglio e Jayme Gimenez que cuidaram das minhas intensas cólicas renais para que eu pudesse concluir este trabalho.

Às(os) primas(os), amigos, amigas e militantes da causa camponesa pela convivência tão essencial em minha vida e, principalmente, em minha pesquisa. $\mathrm{O}$ conjunto deste trabalho deve muito a todas e todos! Obrigada pelo afeto e por partilharem comigo.

Por fim, ao CNPq pela bolsa concedida no ano de 2014, que me permitiu dedicação exclusiva à pesquisa. 


\title{
Resumo
}

LIMA, Lucinei Paes de. Tem gente na roça! O Modo de Vida Camponês em Ribeirão Branco. 2016. Dissertação (Mestrado em Geografia Humana) - Faculdade de Filosofia, Letras e Ciências Humanas, Universidade de São Paulo, São Paulo, 2016.

A presente dissertação discute o modo de vida camponês, o processo e as características que propiciam a reprodução dessa classe e, em particular, os camponeses de Ribeirão Branco-SP. O trabalho aborda o conceito de campesinato e, por meio da análise de caso, destaca os aspectos que entremeiam a unidade de produção camponesa e a maneira como ela se insere, através de relações não capitalistas, na sociedade contemporânea.

Palavras-chave: modo de vida; produção camponesa; cultivo de tomates; terra de trabalho; cultura e vida de bairro.

\begin{abstract}
LIMA, Lucinei Paes de. There are people in the countryside! The Peasant way of life in Ribeirão Branco. 2016. Dissertation (Masters in Human Geography) - Faculdade de Filosofia, Letras e Ciências Humanas, Universidade de São Paulo, São Paulo, 2016.

This dissertation discusses the peasant way of life - the process and the characteristics that allow the reproduction of this class and, in particular, the peasants of Ribeirão Branco-SP.

The work deals with the concept of peasantry and makes case analysis in order to highlight the aspects that intertwine peasant production unit and how it fits into, through non-capitalist relations in contemporary society.
\end{abstract}

Keywords: way of life; peasant production; tomatoes cultivation; lands of working; culture and neighborhood life. 



\section{Sumário}

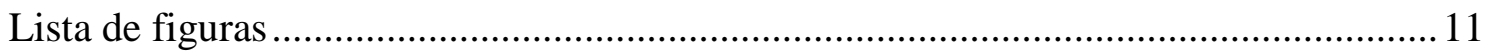

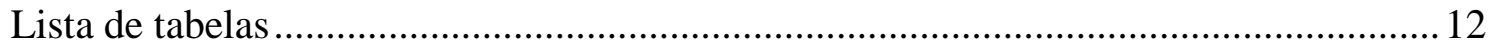

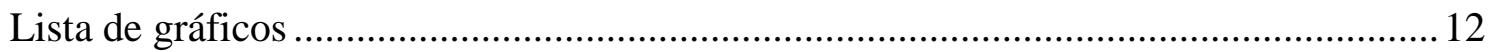

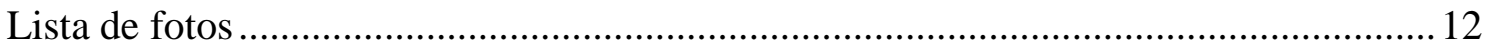

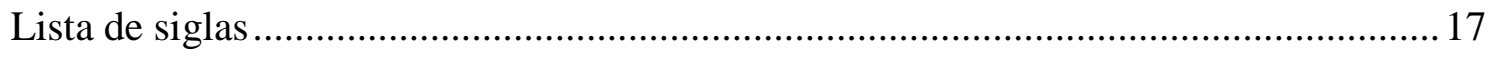

1 Introdução ..............................................................................................................................19

2 Características socioeconômicas, históricas e geográficas de Ribeirão Branco............22

2.1 Indicadores econômicos e sociais de Ribeirão Branco .............................................2 24

2.2 A produção de tomates em Ribeirão Branco ......................................................... 30

3 A produção capitalista em Ribeirão Branco: a monocultura do tomate .......................37

4 A produção camponesa em Ribeirão Branco: produção de tomate e diversificação da produção ..................................................................................................................................................................5 56

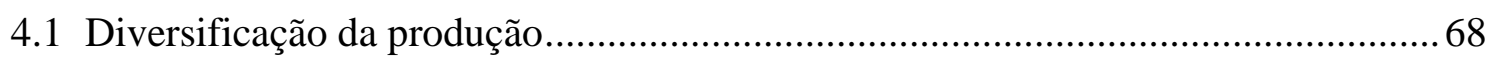

5 Recriação camponesa: os caminhos à terra de trabalho .............................................85

6 Modo de vida camponês ..................................................................................................109

6.1 Um personagem não compreendido no espaço político ....................................... 112

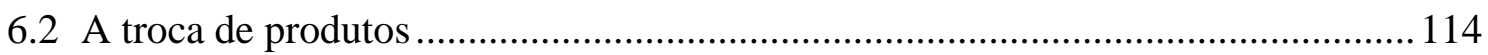

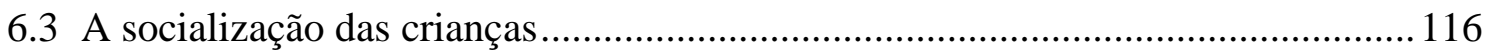

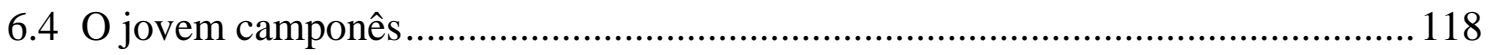

7 Vida de bairro ............................................................................................................................... 122

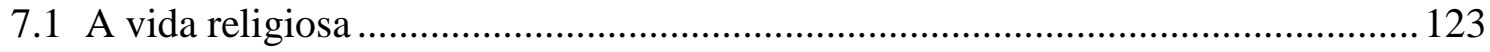

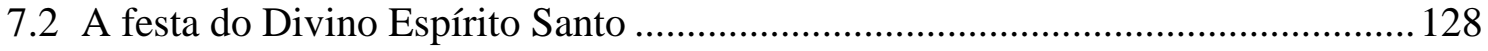

7.3 A Festa do Divino Espírito Santo de Ribeirão Branco ............................................ 137

7.4 A Festa do Divino de Ribeirão Branco em 2015 .................................................... 143

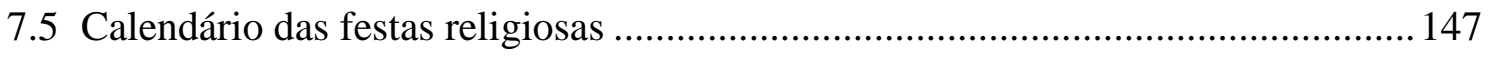

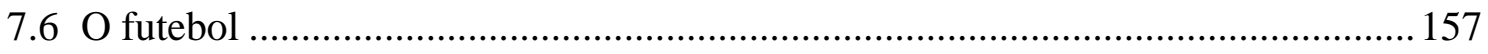

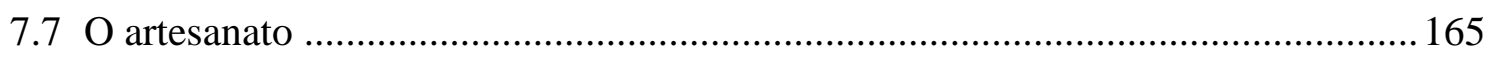

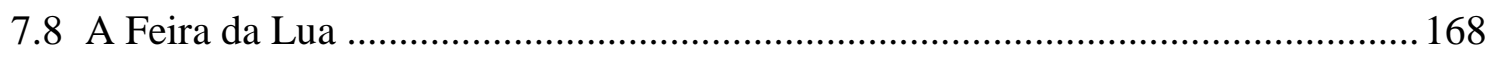

7.9 Projeto "Na Roça também se faz Cultura" ....................................................... 171

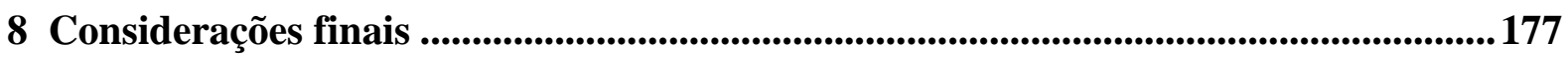

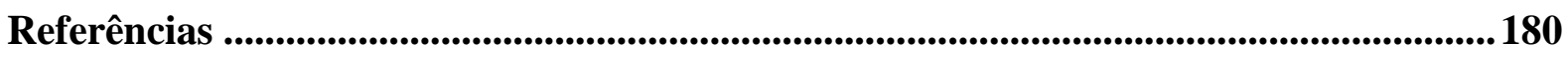

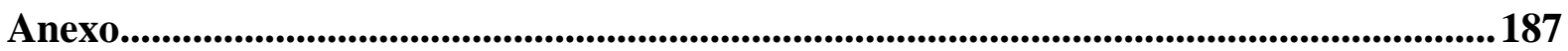





\section{Lista de figuras}

Figura 1: Localização da área de pesquisa no estado do São Paulo. 23

Figura 2: Localização da área de pesquisa no município de Ribeirão Branco. .23

Figura 3: IDHM do município de Ribeirão Branco no estado de São Paulo. ...........................25

Figura 4: População residente rural no estado de São Paulo......................................................26

Figura 5: Estabelecimentos agropecuários do estado de São Paulo.......................................29

Figura 6: Participação do Brasil na produção mundial de tomates (apud DIEESE, 2010)......30

Figura 7: Quantidade de tomate produzida (em toneladas) nos principais estados produtores entre os anos de 2000 e 2007 (apud DIEESE, 2010).

Figura 8: Principais produtores de tomate do estado de São Paulo (apud VILELA, 2009)..... 33

Figura 9: Distribuição geográfica e número de produtores de tomate envarado no estado de. 34 Figura 10: Produção nacional de tomates de 2014 a 2016 (apud CEPEA, 2016, p. 21).......... 35

Figura 11: No brasão de Ribeirão Branco, a produção de tomate e milho................................36

Figura 12: Ata de reunião entre o Sindicato de Empregados Rurais de Ribeirão Branco e Guapiara e o Sindicato Rural de Ribeirão Branco.

Figura 13: Ata de reunião entre o Sindicato de Empregados Rurais de Ribeirão Branco e Guapiara e o Sindicato Rural de Ribeirão Branco (cont.).......................................55

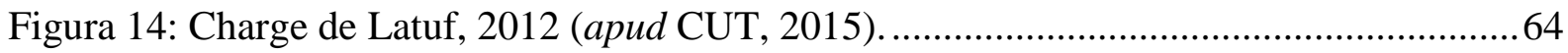

Figura 15: Número de famílias residentes nos projetos do Banco da Terra e do Crédito Fundiário no estado de São Paulo.

Figura 16: Caderno de orações e hinos em louvor ao Divino Espírito Santo.

Figura 17: Hino que anuncia que a bandeira do Divino está chegando. Caderno de orações e hinos em louvor ao Divino Espírito Santo. 134

Figura 18: Orações realizadas durante a visita da bandeira do Divino. Caderno de orações e hinos em louvor ao Divino Espírito Santo. 135

Figura 19: Símbolos do Divino Espírito Santo. Caderno de orações e hinos da bandeira do Divino. 142

Figura 20: Cartaz da festa do padroeiro de Ribeirão Branco. ..............................................147

Figura 21: Cartaz da Festa do Divino Espírito Santo. ......................................................... 148

Figura 22: Cartaz da Festa de Nossa Senhora da Conceição. 149 


\section{Lista de tabelas}

Tabela 1: Coordenadas dos locais visitados durante a pesquisa de campo.

Tabela 2: População residente por situação do domicílio e sexo em Ribeirão Branco (2010).27

Tabela 3: População total por situação do domicílio e sexo em Ribeirão Branco (1991-2010). 27

Tabela 4: Área plantada e produção de tomate no Brasil em 2015 e 2016.............................. 32

Tabela 5: Produção paulista de tomate envarado na safra de 2015. 36

\section{Lista de gráficos}

Gráfico 1: Crescimento da população urbana no Brasil de 1960 a 2010. 28

\section{Lista de fotos}

Foto 1: Gabinete do prefeito de Ribeirão Branco, Sandro Sala..... 44

Foto 2: Fazenda do grupo Condor. No detalhe, o alojamento onde os assalariados residem durante a safra. Bairro Coimbra. 49

Foto 3: Alojamento da Fazenda Santa Rosa, parceira do grupo Santa Bárbara e Condor, bairro do Rio Apiaí 49

Foto 4: Plantação de tomates da empresa Condor em terras arrendadas, bairro Cai-Cai...... 50

Foto 5: Plantação de tomates da empresa Condor. Fazenda Fiuza, bairro do Rio Apiaí....... 50

Fotos 6 e 7: Placas alertam para o perigo dos agrotóxicos utilizados nas plantações de tomate.

Fazenda Fiuza (plantação da empresa Condor), bairro do Rio Apiaí........................ 51

Foto 8: José Vicente, diretor do Sindicato de Empregados Rurais de Ribeirão Branco ........ 53

Foto 9: Camponeses plantando tomates. Associação dos Produtores da Microbacia do Rio Apiaí Guaçu - Banco da Terra, bairro Coimbra. 57

Foto 10: Crianças camponesas na plantação de tomates: toda a família trabalha. Associação dos Produtores da Microbacia do Rio Apiaí Guaçu - Banco da Terra, bairro Coimbra. ........57

Foto 11: Lucimara Barros e os bolinhos de chuva preparados para o café coletivo. Associação dos Produtores da Microbacia do Rio Apiaí Guaçu - Banco da Terra, bairro Coimbra. .......58 
Foto 12: Confraternização depois do plantio coletivo do tomate. Associação dos Produtores da Microbacia do Rio Apiaí Guaçu - Banco da Terra, bairro Coimbra. .58

Foto 13: Valdinei de Jesus colhendo tomate. Associação dos Produtores da Microbacia do Rio Apiaí Guaçu - Banco da Terra, bairro Coimbra.

Foto 14: Colada utilizada para colher os tomates. Associação dos Produtores da Microbacia do Rio Apiaí Guaçu - Banco da Terra, bairro Coimbra.

Foto 15: Caixas com tomates colhidos. Associação dos Produtores da Microbacia do Rio Apiaí Guaçu - Banco da Terra, bairro Coimbra.

Foto 16: Roça de tomate. Associação dos Produtores da Microbacia do Rio Apiaí Guaçu Banco da Terra, bairro Coimbra.

Foto 17: Mulheres recolhendo a produção de tomates logo depois de colhidos. Associação dos Produtores da Microbacia do Rio Apiaí Guaçu - Banco da Terra, bairro Coimbra. ... 66

Foto 18: Sra. Luciane conduz o trator com a sua produção para seleção e embalagem. Associação dos Produtores da Microbacia do Rio Apiaí Guaçu - Banco da Terra. 66

Foto 19: Sra. Maria torrando a farinha no forno, bairro dos Boavas. .71

Foto 20: Quebra de milho com uso de trabalho acessório, bairro do Rio Apiaí. .73

Foto 21: Bandeira de milho, sítio São Luiz, bairro do Rio Apiaí. 73

Foto 22: Conta feita pelo Sr. Luiz mostrando a despesa, a receita e os 147,50 reais de rendimentos com sua plantação de milho. Bairro do Rio Apiaí, jul. 2015. .75

Foto 23: Estrada para o bairro da Boa Vista - floresta preservada. .79

Foto 24: Produção de caqui do sítio de Vera e Mauro, bairro da Boa Vista. 80

Foto 25: O casal Vera e Mauro. 80

Foto 26: Mauro alimentando as galinhas. 81

Foto 27: Ninho encontrado durante caminhada pelo sítio São Luiz, bairro do Rio Apiaí.....81

Foto 28: Secagem do feijão para consumo da família no sítio São Luiz, bairro do Rio Apiaí. 82 Foto 29: Milho verde sendo ralado para o almoço de mingau com frango caipira. Associação dos Produtores da Microbacia do Rio Apiaí Guaçu - Banco da Terra, bairro Coimbra. ... 82

Foto 30: Horta com verduras, legumes e plantas medicinais - variedade de culturas na propriedade camponesa. Associação dos Produtores da Microbacia do Rio Apiaí Guaçu - Banco da Terra, bairro Coimbra.

Foto 31: Cantinho das sementes já separadas para o plantio. Sítio Primavera, bairro do Rio Apiaí.

Foto 32: Sra. Nilda, marido e filha: vida nova com a aquisição da propriedade. Bairro da Serra Velha. 88 
Foto 33: Propriedade da família da Sra. Nilda: diversificação camponesa. Bairro da Serra Velha.

Foto 34: Sr. Nilson, em período de entressafra, na sua roça de ervilha quase finalizada...... 90

Foto 35: O casal Luiz Gonzaga e Zeneide durante a entrevista na Associação dos Produtores da Microbacia do Rio Apiaí Guaçu - Banco da Terra, bairro Coimbra. 100

Foto 36: O gado do Sr. Luiz e da Sra. Zeneide. Associação dos Produtores da Microbacia do Rio Apiaí Guaçu - Banco da Terra, bairro Coimbra. 100

Foto 37: Cestas de verduras separadas para serem entregues direto aos consumidores. Associação de Agricultores Familiares Águia Dourada - Crédito Fundiário, bairro Serra Velha. 102

Foto 38: Os irmãos Laércio, Claudinéia e Wilson, à direita. Associação de Agricultores

Familiares Águia Dourada - Crédito Fundiário, bairro Serra Velha. 105

Foto 39: Estufa de mudas para o plantio, Associação de Agricultores Familiares Águia Dourada - Crédito Fundiário, bairro Serra Velha. 105

Foto 40: Sra. Zilda na sua plantação de milho, bairro do Rio Apiaí. 107

Foto 41: Doação de produtos, Associação dos Agricultores Familiares do Bairro Pocinho, Sítio Freitas, Guapiara.

Foto 42: Socialização das crianças na plantação de batatas, Sítio São Luiz, bairro do Rio Apiaí. 117

Foto 43: Sra. Maria, de 94 anos, preparando o frango caipira para o almoço, Sítio São Luiz, bairro do Rio Apiaí. 118

Foto 44: Ana Paula, de 21 anos, em sua roça de tomates. Associação dos Produtores da Microbacia do Rio Apiaí Guaçu - Banco da Terra, bairro Coimbra 121

Foto 45: Capela do bairro dos Marques, que tem como padroeiro São Sebastião. À direita está o salão para realização das festas.

Foto 46: Capela do bairro dos Boavas, que tem como padroeira Nossa Senhora Aparecida. À esquerda, o salão de festas.

Foto 47: Capela do bairro do Rio Apiaí, que tem como padroeiros Santa Rosa de Lima e São Paulo Apóstolo. 126

Foto 48: Capela do bairro da Boa Vista, que tem como padroeiros São Miguel e São Domingos. À esquerda, o salão de festas; à direita, a escola desativada por falta de alunos. 126

Foto 49: Escola rural do bairro do Rio Apiaí. Alunos da primeira série ensino fundamental....127

Foto 50: Fachada da Igreja matriz de Ribeirão Branco. 129

Foto 51: Imagem interna da Igreja matriz de Ribeirão Branco. 130 
Foto 52: Jovens na concentração para a caminhada da bandeira do Divino no bairro do Rio Apiaí. 132

Foto 53: Lanche servido pelo morador aos participantes da bandeira do Divino. 136

Foto 54: Última visita da noite na caminhada da bandeira do Divino. 136

Foto 55: Primeiro casal de festeiros do Divino de Ribeirão Branco, Sr. Bil e sua esposa...140

Foto 56: Primeiro coral de canto para a Festa do Divino de Ribeirão Branco.......................140

Foto 57: Primeira festa do Divino de Ribeirão Branco, jun. 1979.......................................141

Foto 58: José Luiz (direita) e o pároco do município, Pe. Cícero Vieira...............................141

Foto 59: Cavaleiros abrem e os fiéis acompanham a procissão do Divino em Ribeirão Branco..144 Foto 60: Caminhada da procissão do Divino até a igreja matriz. ........................................ 144

Foto 61: Início da procissão com o andor de São Benedito sempre à frente. .......................146

Foto 62: Músicos com seus instrumentos durante a procissão na Festa do Divino. .............146

Foto 63: Chegada da imagem do Senhor Bom Jesus à capela do bairro do Rio Apiaí.........150

Foto 64: Visita do Senhor Bom Jesus, procissão até a capela do bairro do Rio Apiaí. ........151

Foto 65: Visita do Senhor Bom Jesus no bairro do Rio Apiaí.............................................151

Foto 66: Cavalgada da fé na Festa de Nossa Senhora da Conceição, dez. 2015..................152

Foto 67: Chegada da cavalgada à cidade. No detalhe, Padre Cícero com a água benta. .....153

Foto 68: Último dia da novena de Natal na capela do bairro do Rio Apiaí. O presépio é montado no primeiro dia e permanece até o último dia da novena. ......................153

Foto 69: Peça de Natal apresentada pelas crianças do bairro do Rio Apiaí..........................154

Foto 70: Peça de teatro sobre o nascimento de Jesus apresentada pelas crianças do bairro do Rio Apiaí.

Foto 71: Confraternização no encerramento da novena de Natal do bairro do Rio Apiaí...155

Foto 72: Claudinéia com seu marido e filha à esquerda e, à direita, seu irmão, Claudinei, e seu sobrinho, Rafael, exibindo os troféus que o bairro do Rio Apiaí ganhou nas competições.

Foto 73: Sr. Euriquinho e sua esposa, dona Lourdes. Ele agenda jogos de futebol com bairros vizinhos. Bairro do Rio Apiaí. 161

Foto 74: Primeiro time de futebol feminino do bairro do Rio Apiaí, 1995. 162

Foto 75: Time feminino do bairro do Rio Apiaí em 1997, torneio no bairro dos Paes. 162

Foto 76: Time feminino do bairro do Rio Apiaí em 1998, torneio no bairro Capela de São Pedro.

Foto 77: Sr. Euriquinho e o time de futebol masculino do bairro do Rio Apiaí em 1998...163 Foto 78: Time feminino do bairro do Rio Apiaí em 2006, amistoso no bairro do Rio Apiaí.... 164 
Foto 79: Time de futebol feminino do bairro do Cerrado, amistoso contra o bairro do Rio Apiaí em 2015. Estádio Municipal de Ribeirão Branco......................................... 164

Foto 80: Fabiana Almeida na loja de artesanato municipal de Ribeirão Branco. ................ 166

Foto 81: Exposição de Ribeirão Branco na feira de artesanato "Revelando São Paulo".... 167

Foto 82: As mulheres são a maioria dos artesãos de Ribeirão Branco................................ 167

Foto 83: Vanuza, camponesa e artesã do bairro do Batista na Feira da Lua. ..................... 169

Foto 84: Barraca da Maria na Feira da Lua: toda a sua produção é de derivados do milho. .....169

Foto 85: Barraca da Neuza que, com suas filhas, prepara o típico "encapotado" (bolinho frito de farinha de milho recheado de frango e cheiro verde).

Foto 86: Barraca de verduras, legumes e frutas de Daiane de Souza e Aline Santos, camponesas do bairro do São Roque.

Foto 87: Público assistindo à orquestra de violeiros de Ribeirão Branco no projeto "Na Roça também se faz Cultura”, bairro Capela de São Pedro, jun. 2015.

Foto 88: Apresentação de teatro no projeto "Na Roça também se faz Cultura", bairro Capela de São Pedro, jun. 2015.

Foto 89: Apresentação de rap no projeto "Na Roça também se faz Cultura", bairro Capela de São Pedro, jun. 2015.

Foto 90: Apresentação de dança no projeto "Na Roça também se faz Cultura", bairro Capela de São Pedro, jun. 2015. 174

Foto 91: Apresentação musical no projeto "Na Roça também se faz Cultura", bairro Capela de São Pedro, jun. 2015 174

Foto 92: A biblioteca itinerante e o artesanato municipal são atrações do projeto "Na Roça também se faz Cultura”, bairro Capela de São Pedro, jun. 2015. 175

Foto 93: Centro do bairro Capela de São Pedro no dia da realização do projeto "Na Roça também se faz Cultura", jun. 2015. 


\section{Lista de siglas}

Ceagesp Companhia de Entrepostos e Armazéns Gerais de São Paulo

Ceasa Central de abastecimento

CEB Comunidade Eclesial de Base

Cepea Centro de Estudos Avançados em Economia Aplicada

Contag Confederação Nacional dos Trabalhadores na Agricultura

DAP Declaração de aptidão ao Pronaf

DCF Departamento de Crédito Fundiário

Dieese Departamento Intersindical de Estatística e Estudos Socioeconômicos

FAO Food and Agriculture Organization (Organização das Nações Unidas para a Alimentação e a Agricultura)

Fetraf Federação dos Trabalhadores na Agricultura Familiar

IBGE Instituto Brasileiro de Geografia e Estatística

IDHM Índice de desenvolvimento humano municipal

IEA Instituto de Economia Aplicada do estado de São Paulo

Incra Instituto Nacional de Colonização e Reforma Agrária

Itesp Instituto de Terras do Estado de São Paulo

LUPA Levantamento censitário das unidades de produção do estado de São Paulo

MDA Ministério do Desenvolvimento Agrário

ONU Organização das Nações Unidas

PAA Programa de Aquisição de Alimentos

PJR Pastoral da Juventude Rural

PLR Participação nos lucros ou resultados

Pnae Programa Nacional de Alimentação Escolar

PNCF Programa Nacional de Crédito Fundiário

Pnud Programa das Nações Unidas para o Desenvolvimento

Pronaf Programa Nacional de Fortalecimento da Agricultura Familiar

Prouni Programa Universidade para Todos

SRA Secretaria de Reordenamento Agrário 


\section{Introdução}

Esta dissertação tem como objetivo analisar o modo de vida camponês e, em particular, os camponeses de Ribeirão Branco-SP. Todo o esforço dedicado a esta pesquisa teve como objetivo estudar o campesinato enquanto uma classe plenamente ativa na sociedade contemporânea, descartando a hipótese de que esses sujeitos estariam em processo de desaparecimento.

A escolha do tema central foi uma árdua tarefa diante de todas as possibilidades que foram surgindo durante o intenso trabalho de campo, realizado em vários momentos da pesquisa para corrigir e completar informações, colher dados, imagens e depoimentos, que nos renderam horas de trabalho de transcrição.

Dentre os temas gerados durante esse processo, podemos destacar a questão fundiária e a efetiva ocupação da terra no município; a problemática do agrotóxico através do seu uso indiscriminado nas lavouras de tomate; a plantação do pinus e do eucalipto e seu avanço nesse território.

Elegemos o campesinato como mote e trouxemos para o trabalho abordagens teóricas de autores identificados com o tema e com as observações extraídas da pesquisa de campo, que nos ampararam em evidenciar esse modo de vida e sua recriação.

A escolha do município de Ribeirão Branco se deu por dois fatores principais. Em primeiro lugar, por se aproximar da realidade teórica sugerida pelos autores que estudam o campesinato, considerando as características econômicas, sociais e culturais do município. Em segundo, mas não menos importante, pelo fato da minha história de vida estar ligada a esse lugar: ali nasci e exerci a minha primeira profissão - a de camponesa. $\mathrm{O}$ fato de ter familiares residindo na região também facilitou o deslocamento e a estadia no município pesquisado.

Durante o trabalho de campo, identificamos que a produção de tomates era a principal cultura agrícola do município de Ribeirão Branco e que era produzida tanto pelos capitalistas quanto pelos camponeses. Durante os debates da banca de qualificação, notamos que a existência de camponeses e capitalistas produzindo o mesmo produto poderia potencializar a pesquisa e contribuir para compreendermos as especificidades da produção camponesa.

A partir disso, estruturamos o nosso trabalho da seguinte maneira:

O capítulo 2 traz uma apresentação do município de Ribeirão Branco, suas características socioeconômicas, históricas e geográficas, e dados estatísticos sobre a produção 
de tomates ali existente, demonstrando que o município estudado é um dos principais produtores dessa cultura no país.

No capítulo 3, discorremos sobre a produção capitalista de tomates em Ribeirão Branco. Apresentamos os dados sobre a quantidade produzida e, com base nos depoimentos colhidos, tratamos dos altos custos investidos nessa plantação. Também constatamos que os maiores produtores operam toda a "cadeia do tomate", que vai do plantio até a entrega do produto.

No capítulo 4, apresentamos a produção camponesa em Ribeirão Branco - a produção de tomate e a diversificação produtiva dos camponeses. Vimos que mesmo os que produzem tomate têm uma relação com a produção que não é meramente econômica - são camponeses que buscam a sua recriação através do cultivo de tomate e demais culturas. Também evidenciamos o quanto a produção diversificada é fundamental para garantir esse modo de vida. Não deixamos de apontar a problemática dos agrotóxicos e a preocupação com a extinção das sementes nativas. O protagonismo das personagens descritas nesse capítulo conta por si só de que se trata a lógica camponesa.

No capítulo 5, discorremos sobre a recriação camponesa. Aqui, as riquezas dos depoimentos revelam o difícil trajeto dos camponeses para alcançarem a terra de trabalho. Discutimos as diferentes formas de acesso, como a possibilidade de compra e o arrendamento. Além disso, abordamos a situação das famílias camponesas que residem e se recriam nos programas do governo federal, o "Banco da Terra" e o Programa Nacional de Crédito Fundiário (PNCF) - ou apenas "Crédito Fundiário".

No capítulo 6, discutimos o conceito do campesinato e o modo de vida camponês. Também trouxemos elementos do trabalho de campo que nos ajudaram a interpretar esse modo de vida, tais como as trocas de produtos, a socialização das crianças, os idosos camponeses e, ainda, a condição de jovem camponês.

No último capítulo, abordamos a vida de bairro a partir de um vasto material alçado no trabalho de campo. Apresentamos as capelas dos bairros rurais que visitamos e dissertamos sobre a história da Festa do Divino Espírito Santo em Ribeirão Branco. Também exploramos as demais atividades religiosas como a Festa do Padroeiro da Cidade "Senhor Bom Jesus", a Festa de Nossa Senhora da Conceição e a Dança de São Gonçalo, além das principais atividades culturais, como o futebol feminino e masculino, o artesanato municipal, a Feira da Lua e o projeto "Na roça também se faz cultura". Atividades que demonstram a importância da preservação dos momentos de interação e da religiosidade inerentes ao campesinato. 
Enfim, embarcamos em busca de conhecimentos sobre o campesinato de Ribeirão Branco e tivemos o privilégio de vivenciar um pouco do que é esse modo de vida. E tudo isso só foi possível porque, sim...

Tem gente na roça! 


\section{Características socioeconômicas, históricas e geográficas de Ribeirão Branco}

O município de Ribeirão Branco localiza-se no sudoeste do estado de São Paulo. Segundo o censo do IBGE de 2010, possui uma população de 18.269 habitantes e uma área de $697,5 \mathrm{~km}^{2}$, distando $295 \mathrm{~km}$ da capital paulista. Faz fronteira com os municípios de Itapeva, Nova Campina, Apiaí e Guapiara. Todos esses municípios têm como principais atividades econômicas a agricultura, a silvicultura e o comércio local. Além disso, encontram-se próximos ao maior contínuo de mata atlântica paulista.

Segundo o IBGE (2015), Ribeirão Branco está localizado entre os rios Taquari Mirim e Apiaí Guaçu, e o povoado denominado Senhor Bom Jesus do Ribeirão Preto. Sua formação se deu em torno de uma capela em louvor a esse santo, nas terras que foram doadas por Francisco Caetano da Silva e sua esposa, Maria Custódia de Jesus. Essa região era chamada de Boa Vista do Campinho.

As escrituras das terras doadas datam de 28 de novembro de 1864. A partir desse momento foram se instalando novos moradores em torno da capela. $\mathrm{O}$ distrito foi criado com o nome de Bom Jesus de Ribeirão Branco, por Lei provincial n. 28, de 29 de março de 1883, e pertencia ao município de Faxina (hoje Itapeva).

Em 1892, o distrito foi elevado à categoria de vila, passando a chamar somente Ribeirão Branco, pela Lei estadual n. 83, de 6 de setembro daquele ano. Foi desmembrado do município de Faxina em 1906, pela Lei estadual n. 1.038, de 19 de dezembro, passando a ser sede municipal. Em 1934, o município foi extinto e voltou a ser incorporado, como distrito, ao município de Faxina (Decreto n. 6.448, de 21 de maio). Pelo Decreto estadual n. 9.775, de 3 de novembro de 1938, Faxina passou a se chamar Itapeva.

No ano de 1944, Ribeirão Branco volta a ser um município pelo Decreto-lei estadual n. 14.334, de 30 de novembro, desmembrando-se novamente do município de Itapeva. Essa reinstalação foi oficializada em $1^{\text {o }}$ de janeiro de 1945.

Ribeirão Branco tem dois distritos, Itaboa e Campina de Fora, ambos criados em dezembro de $1992^{1}$.

A seguir, podemos verificar a localização da nossa área de estudo e a tabela com as coordenadas geográficas de alguns dos bairros e propriedades visitados durante o trabalho de campo.

1 Todas essas informações sobre a formação histórica do município estão em IBGE (2015). 


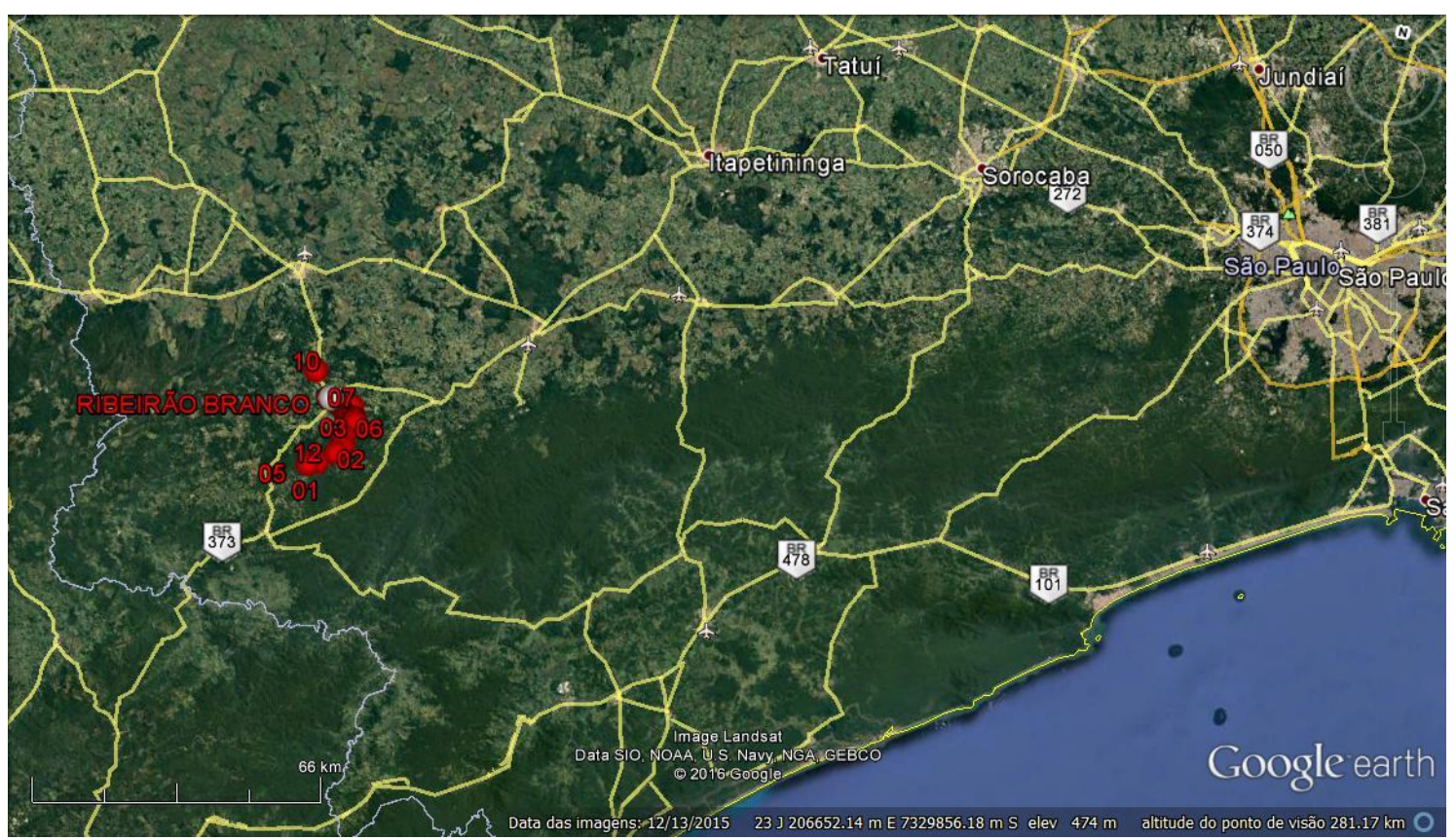

Fonte: Google Earth. Org.: Sueli Almeida, 2016.

Figura 1: Localização da área de pesquisa no estado do São Paulo.

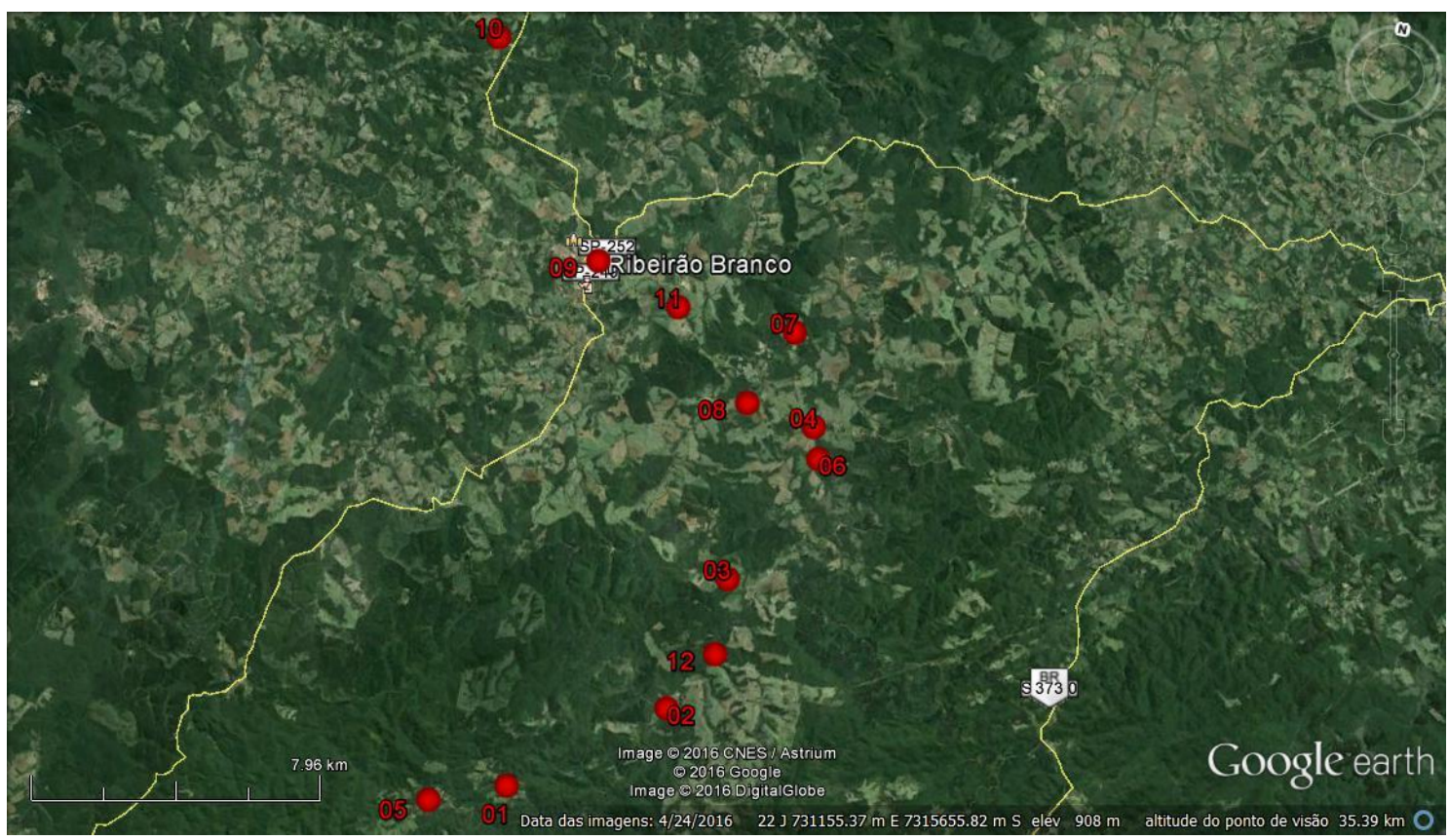

Fonte: Google Earth. Org.: Sueli Almeida, 2016.

Figura 2: Localização da área de pesquisa no município de Ribeirão Branco. 
Tabela 1: Coordenadas dos locais visitados durante a pesquisa de campo.

\begin{tabular}{lcc}
\hline \multicolumn{1}{c}{ Descrição do ponto } & $\begin{array}{c}\text { Coordenada Leste } \\
\text { (UTM) }\end{array}$ & $\begin{array}{c}\text { Coordenada Norte } \\
\text { (UTM) }\end{array}$ \\
\hline Bairro da Boa Vista (centro do bairro) & 726973 & 7304775 \\
$\begin{array}{l}\text { Bairro dos Marques } \\
\text { Bairro Coimbra (Associação dos }\end{array}$ & 730940 & 7307658 \\
$\begin{array}{l}\text { Produtores da Microbacia do Rio Apiaí } \\
\text { Guaçu - Banco da Terra) }\end{array}$ & 731951 & 7311459 \\
Bairro do Rio Apiaí & 733535 & 7315996 \\
Bairro da Boa Vista (Sertão) & 724926 & 7304013 \\
Faz. Santa Rosa (produção capitalista) & 733818 & 7315156 \\
$\begin{array}{l}\text { Bairro da Serra Velha } \\
\text { Bairro da Serra Velha (Associação de }\end{array}$ & 732544 & 7318461 \\
Agricultores Familiares Águia Dourada - & 731607 & 7316319 \\
Crédito Fundiário) & & \\
Sede do Município (Igreja matriz) & 726842 & 7319424 \\
Faz. Descanso (produção capitalista) & 723029 & 7324965 \\
Bairro dos Boavas & 729246 & 7318568 \\
Fazenda Cai, Cai (produção capitalista) & 731986 & 7309368 \\
\hline
\end{tabular}

Org.: Lucinei Paes de Lima, jul. 2016.

\subsection{Indicadores econômicos e sociais de Ribeirão Branco}

Em relação aos indicadores econômicos e sociais do município, um estudo do Programa das Nações Unidas para o Desenvolvimento (PNUD et al., s.d.), divulgado em julho de 2013, apontou que Ribeirão Branco tem o pior índice de desenvolvimento humano municipal (IDHM) do estado de São Paulo. O IDHM atingiu 0,639 pontos e a renda média mensal dos moradores é de $\mathrm{R} \$ 318,44$. Já no comparativo nacional, Ribeirão Branco fica na $3.312^{a}$ posição dentre os 5.565 municípios brasileiros. A Figura 3 apresenta o IDHM dos municípios do estado de São Paulo (IBGE, 2015).

O fato de Ribeirão Branco apresentar o pior IDHM do estado de São Paulo nos instigou ainda mais a analisar esse território.

Esse município se aproxima da realidade de muitos municípios brasileiros que podemos apontar, à primeira vista, como municípios camponeses, ou seja, aqueles onde a maior parte dos estabelecimentos são de pequenas unidades de produção e cultivados prioritariamente pela força de trabalho das famílias. 


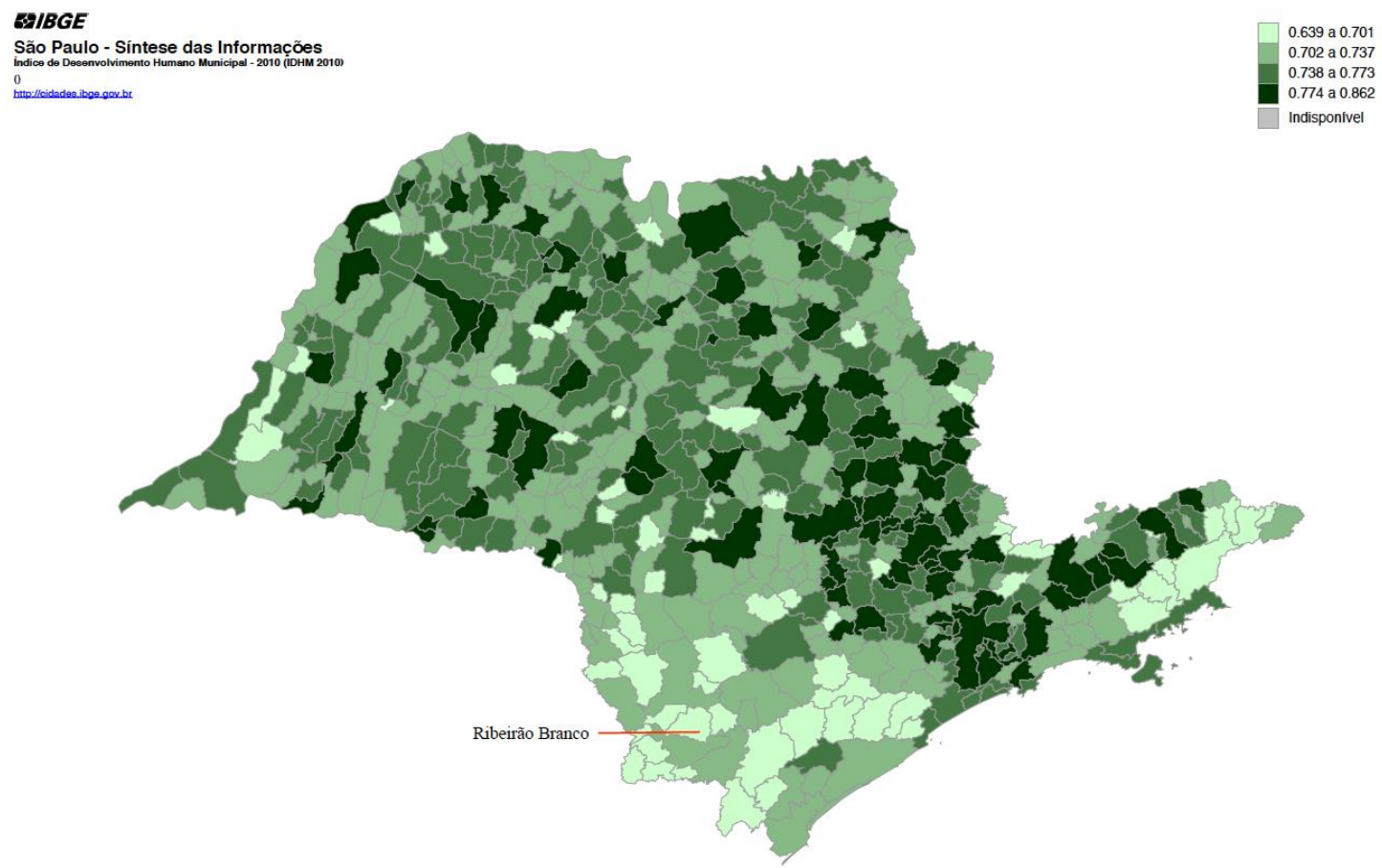

Fonte: IBGE, 2010. Org: Lucinei Paes de Lima, 2016.

Figura 3: IDHM do município de Ribeirão Branco no estado de São Paulo.

Importante destacar aqui que um dos elementos que compõem o IDHM trata dos rendimentos e ganhos da população e, em se tratando de uma realidade camponesa, é necessário levar algumas peculiaridades em consideração. Como nos adverte Paulino:

Isso nos obriga a rever os indicadores tradicionais dos rendimentos camponeses, já que não foi suficientemente aclarado qual o patamar definidor do nível de miserabilidade relacionada a essa classe.

Onde entra a segurança alimentar da família camponesa? Igualar essa classe aos demais trabalhadores, que obrigatoriamente adquirem tudo o que consomem no mercado, camufla um ganho efetivo que não tem condições de ser computado. (PAULINO, 2012, p. 68)

Essa observação de Paulino nos permite dizer que existem dados que podem não refletir fielmente a realidade dos camponeses e, portanto, podem produzir análises equivocadas e que reforçam o discurso preconceituoso acerca do campesinato brasileiro, considerando-o como representante do "atraso". Desse modo, "empurram" essa classe cada vez mais para as margens da sociedade. Como afirma Shanin:

El grueso de los países con una amplia población campesina comparte gobiernos y políticas que se ocupan ampliamente de la "modernización" y el "crecimiento", visualizados como "ponerse a nivel" de las sociedades industriales en términos de renta nacional, formación del capital, educación, etc. De acuerdo con todos estos índices el campesinado representa como regla, la parte más atrasada de la sociedad y el principal obstáculo para el progreso general. (SHANIN, 1976, p. 59) 
Essas afirmações nos instigam a refletir sobre a complexidade da realidade camponesa. Partindo dos indicadores tratados até aqui, iremos apresentar mais algumas informações que podem nos ajudar a compreender a realidade camponesa no município de Ribeirão Branco.

Na Figura 4, a partir da base dados do IBGE (2010), construímos um mapa em que é possível verificar onde estão os municípios com maior número de residentes rurais no estado de São Paulo.

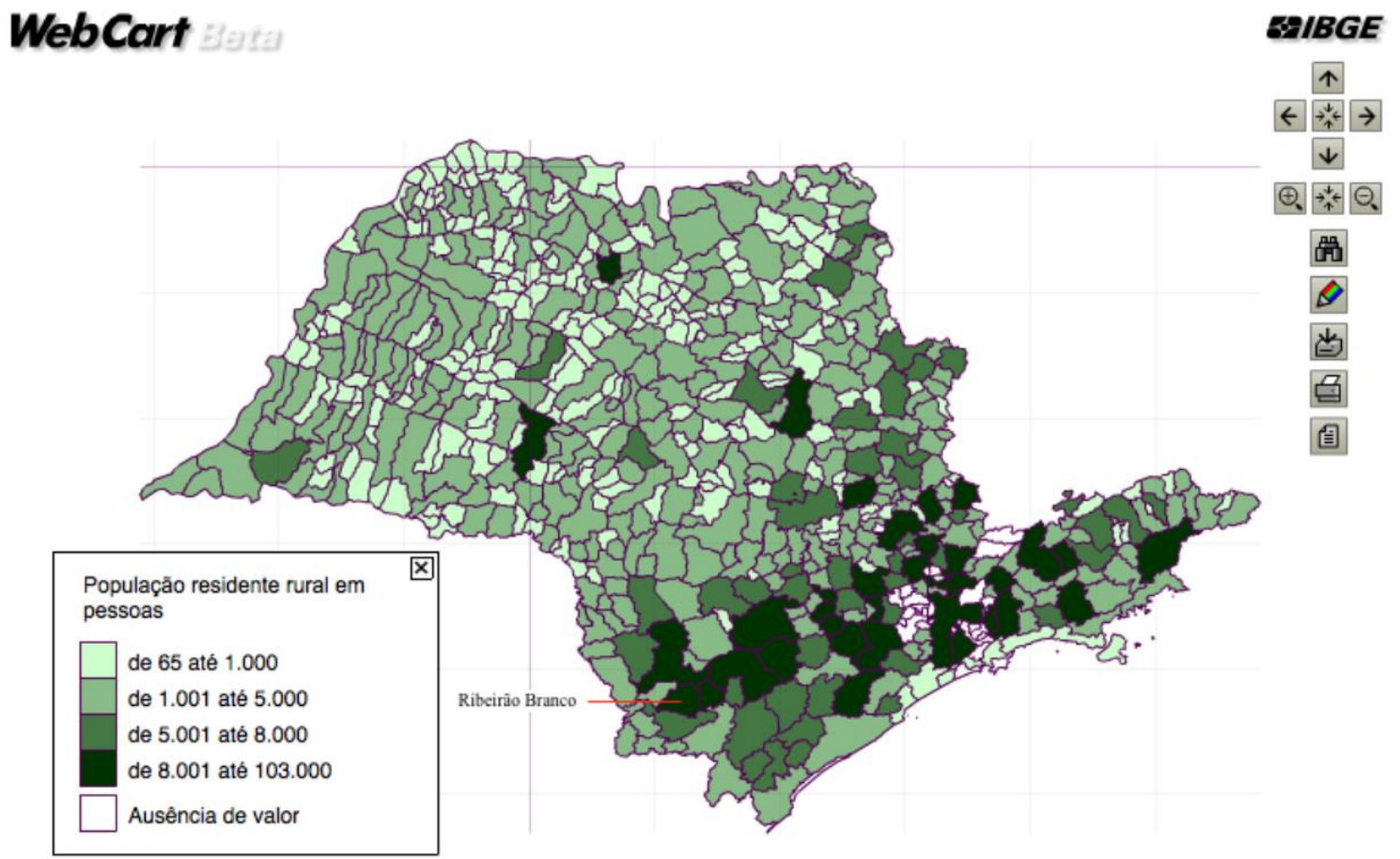

Fonte: IBGE, 2010. Org: Lucinei Paes de Lima, 2016, no WebCart beta. ${ }^{2}$

Figura 4: População residente rural no estado de São Paulo.

Como podemos observar, o município de Ribeirão Branco possui grande concentração de residentes rurais. Na Tabela 2, podemos observar um equilíbrio entre a população residente urbana e rural. A tabela também detalha essa informação por gênero.

\footnotetext{
${ }^{2}$ A ferramenta WebCArt beta é disponibilizada pelo IBGE em: <http://www.ibge.gov.br/webcart/default.php>.
} 
Tabela 2: População residente por situação do domicílio e sexo em Ribeirão Branco (2010).

\begin{tabular}{lr}
\hline População Total & $\mathbf{1 8 . 2 6 9}$ \\
Urbana & 9.293 \\
Rural & 8.976 \\
Homens & $\mathbf{9 . 3 9 6}$ \\
Homens - área urbana & 4.663 \\
Homens - área rural & 4.733 \\
Mulheres & $\mathbf{8 . 8 7 3}$ \\
Mulheres - área urbana & 4.630 \\
Mulheres - área rural & 4.243 \\
\hline
\end{tabular}

Fonte: IBGE, 2010. Org: Lucinei Paes de Lima, 2016.

Na Tabela 3, apresentamos a população rural e urbana, e de homens e mulheres entre os anos de 1991 e 2010.

Tabela 3: População total por situação do domicílio e sexo em Ribeirão Branco (1991-2010).

\begin{tabular}{|c|c|c|c|c|c|c|}
\hline & \multicolumn{2}{|c|}{1991} & \multicolumn{2}{|c|}{2000} & \multicolumn{2}{|c|}{2010} \\
\hline & Total & $\%$ & Total & $\%$ & Total & $\%$ \\
\hline População Total & 19.278 & 100,00 & 21.231 & 100,00 & 18.269 & 100,00 \\
\hline Homens & 10.069 & 52,23 & 11.094 & 52,25 & 9.396 & 51,43 \\
\hline Mulheres & 9.209 & 47,77 & 10.137 & 47,75 & 8.873 & 48,57 \\
\hline Urbana & 6.504 & 33,74 & 8.985 & 42,32 & 9.293 & 50,87 \\
\hline Rural & 12.774 & 66,26 & 12.246 & 57,68 & 8.976 & 49,13 \\
\hline
\end{tabular}

Fonte: PNUD et al., s.d. Org.: Lucinei Paes de Lima, 2016.

Como a Tabela 2 e a Tabela 3 indicam, o número de residentes rurais em Ribeirão Branco é impactante ${ }^{3}$, a ponto de, em 2010 , um percentual de $49,13 \%$ da população do município viver na área rural.

\footnotetext{
${ }^{3}$ De acordo com as informações obtidas na prefeitura municipal, inclusive com o próprio prefeito Sandro Sala, existem questionamentos referentes à coleta de dados realizada pelo censo do IBGE. Ele afirma que o período de realização das visitas do censo ocorre sempre na entressafra do município. Segundo o prefeito, isso exclui uma grande parte dos trabalhadores rurais que ali residem e que, no período de inverno, saem para trabalhar nas lavouras de tomates em outras regiões. Além disso, o prefeito aponta divergências sobre os limites dos bairros e municípios vizinhos. Segundo ele, famílias que pertencem ao município de Ribeirão Branco foram contadas, no último censo, como pertencendo a outros municípios. Afirmou ainda que, mesmo tendo notificado o IBGE da situação, o erro persiste.
} 
Vale dizer que, mesmo diante da intensificação da urbanização no Brasil ${ }^{4}$ ao longo das últimas décadas (Gráfico 1), o município de Ribeirão Branco demonstra que essa não é uma realidade homogênea. O gráfico abaixo contrasta com a realidade de Ribeirão Branco apresentada. Dessa forma, queremos apontar para o fato de que o campesinato resiste ao modelo de desenvolvimento baseado na proletarização dos trabalhadores.

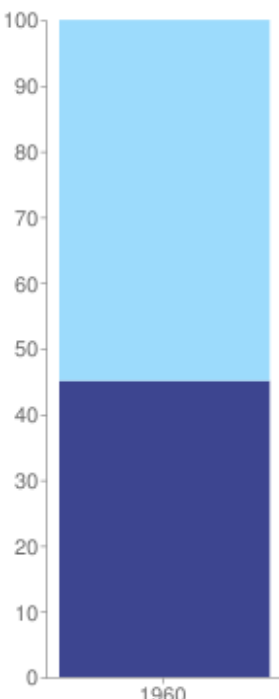

1960

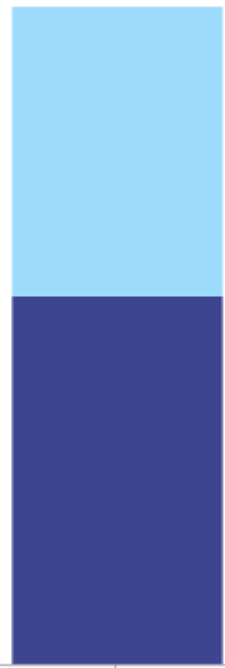

1970

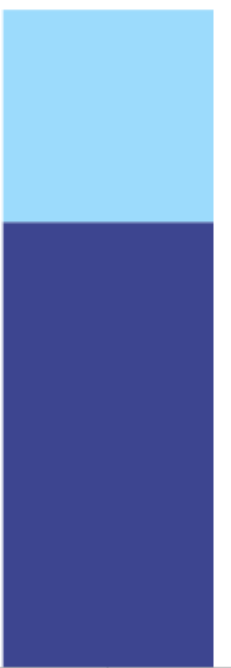

1980

Urbana Rural

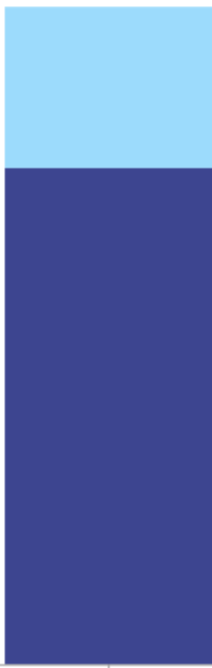

1991

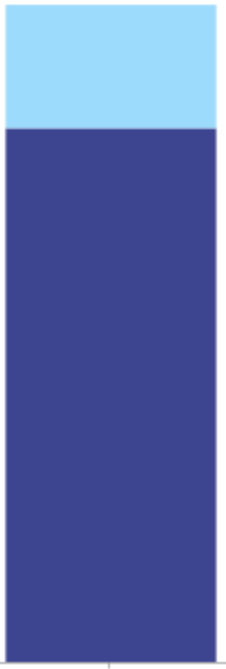

2000

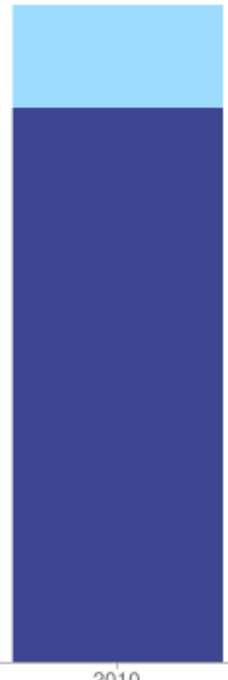

2010

Fonte: IBGE. Censos demográficos. Org.: Lucinei Paes de Lima, 2016.

Gráfico 1: Crescimento da população urbana no Brasil de 1960 a 2010.

Ainda a respeito do cenário nacional em relação à produção agrícola, vale destacar que o censo agropecuário de 2006 (ver FRANÇA et al., 2009, p. 20-24) identificou 4.367.902 estabelecimentos de camponeses, o que representa $84,4 \%$ dos estabelecimentos rurais no país. Segundo o censo, esse contingente de camponeses ocupava uma área de 80,25 milhões de hectares, o que, por sua vez, equivalia a $24,3 \%$ da área ocupada pelos estabelecimentos agropecuários brasileiros. Esse levantamento mostra, portanto, uma estrutura agrária extremamente concentrada: os estabelecimentos citados como não familiares, apesar de representarem apenas 15,6\% do total dos estabelecimentos, ocupavam 75,7\% da área destinada à agropecuária. A área média dos estabelecimentos familiares era de 18,37 ha, e a dos não familiares, de 309,18 ha.

Os estabelecimentos familiares representaram $76 \%$ do total de estabelecimentos e $24 \%$ do total de área. Os estados com maior número de estabelecimentos familiares foram Bahia

\footnotetext{
${ }^{4}$ Ver a taxa de urbanização brasileira em: <http://www.censo2010.ibge.gov.br/sinopse/index.php?dados=8>. Acesso em: ago. 2016.
} 
(665.831; ou 15,2\% do total), Minas Gerais (437.415; ou 10\% do total), Rio Grande do Sul (378.546; ou 8,7\% do total) e Ceará (341.510; ou 7,8\% do total) (FRANÇA et al., 2009).

Ainda sobre os dados do censo agropecuário de 2006, é importante observar o número de estabelecimentos agropecuários da região Sudeste. Ela é a terceira região com maior número de estabelecimentos familiares, com 699.978 estabelecimentos, $16 \%$ do total. Esses estabelecimentos ocupam 12.789.019 ha - 15,9\% do total da área ocupada por esse tipo de estabelecimento no país.

A Figura 5 apresenta o número de estabelecimentos agropecuários no estado de São Paulo, com destaque para o município de Ribeirão Branco ${ }^{5}$.

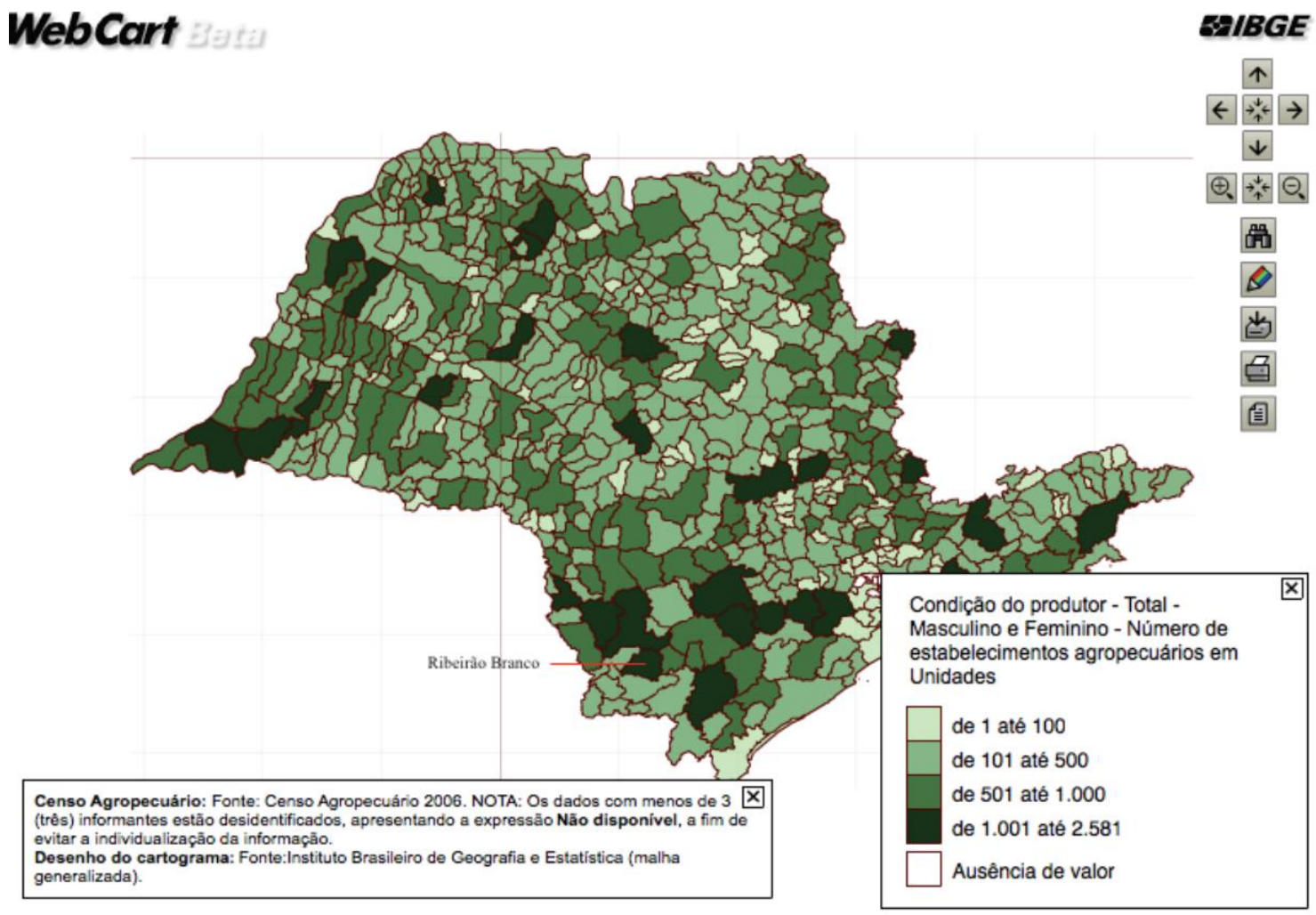

Fonte: IBGE. Censo agropecuário 2006. Org: Lucinei Paes de Lima, 2016, no WebCart beta.

Figura 5: Estabelecimentos agropecuários do estado de São Paulo.

\footnotetext{
${ }^{5}$ Ribeirão Branco aparece aqui com o total de 1.159 estabelecimentos agropecuários.
} 


\subsection{A produção de tomates em Ribeirão Branco}

Ao realizarmos o trabalho de campo em Ribeirão Branco, notamos, logo no início, o quanto a vida dos camponeses naquele município é marcada pela produção do tomate. A maioria dos camponeses com os quais tivemos contato durante nossa pesquisa de campo produziram ou ainda produzem tomates e relataram diversas histórias de melhoria de vida, mas também de falências, relacionadas à produção de tomates.

Também nos deparamos com a produção capitalista de tomates em Ribeirão Branco e nos propusemos a analisar as diferenças entre esses dois modos de produzir o mesmo produto.

Segundo os dados da Organização das Nações Unidas para a Alimentação e a Agricultura - FAO, sigla em inglês (apud CARVALHO; PAGLIUCA, 2007, p. 12), estima-se que a produção de tomates tem aumentado consideravelmente no Brasil e no mundo. O motivo apontado para justificar esse aumento é o de que esse alimento é oferecido em diversos tipos de pratos gastronômicos e o produto, na sua forma industrializada, combina com o mundo contemporâneo, que exige que as pessoas gastem menos tempo no preparo dos alimentos.

Participação na Produção Mundial do Tomate em 2002 e 2008

\begin{tabular}{|c|c|c|c|c|c|}
\hline \multirow[b]{2}{*}{ Paises } & \multicolumn{2}{|c|}{2002} & \multicolumn{2}{|c|}{2008} & \multirow{2}{*}{$\begin{array}{c}\text { Variação } \\
\text { (\%) }\end{array}$} \\
\hline & Produção (T) & $\begin{array}{c}\text { Participação } \\
(\%)\end{array}$ & Produção (T) & \begin{tabular}{|c|} 
Participação \\
$(\%)$
\end{tabular} & \\
\hline China & $27.153 .121,00$ & 23,6 & 33.811 .702 & 26,7 & 24,5 \\
\hline Estados Unidos & $12.383 .200,00$ & 10,8 & 12.575 .900 & 9,9 & 1,6 \\
\hline Turquia & $9.450 .000,00$ & 8,2 & 10.985 .400 & 8,7 & 16,2 \\
\hline Índia & $7.462 .300,00$ & 6,5 & 10.260 .600 & 8,1 & 37,5 \\
\hline Italia & $5.750 .041,00$ & 5,0 & 5.976 .912 & 4,7 & 3,9 \\
\hline Irã, Republica da Islandia & $4.109 .000,00$ & 3,6 & 5.000 .000 & 3,9 & 21,7 \\
\hline Egito & $6.777 .875,00$ & 5,9 & 4.204 .039 & 3,3 & $-38,0$ \\
\hline Brasil & $3.652 .920,00$ & 3,2 & 3867655 & 3,1 & 5,9 \\
\hline Espanha & $3.979 .718,00$ & 3,5 & 3.847 .800 & 3,0 & $-3,3$ \\
\hline Outros & $34.419 .449,00$ & 29,9 & 36.116 .482 & 28,5 & 4,9 \\
\hline Mundial & $115.137 .624,00$ & 100,0 & 126.646 .490 & 100,0 & 10,0 \\
\hline
\end{tabular}

Fonte: FAOStat/IBGE

Eaboração: DIEESE-GO

Figura 6: Participação do Brasil na produção mundial de tomates (apud DIEESE, 2010, p. 4).

Numa pesquisa realizada pelo Departamento Intersindical de Estatística e Estudos Socioeconômicos em 2008 (DIEESE, 2010), os dados apontavam um crescimento de $10 \%$ entre os anos de 2002 e 2008 na produção mundial de tomate. Nesse período, o Brasil se encontrava entre os dez principais produtores, ocupando, naquele momento, a oitava posição (Figura 6). 
No cenário mundial, a produção se concentra em China, Estados Unidos, Turquia e Índia. Esses quatro países detêm 53\% da produção mundial. Como dissemos anteriormente, em 2008 o Brasil ocupava o oitavo lugar no ranking dos maiores produtores mundiais de tomate e a produção nacional se concentrava em três estados da federação: São Paulo, Goiás e Minas Gerais. Juntos, esses estados, detêm $62 \%$ da produção no país. Na Figura 7, podemos verificar a quantidade de tomate produzida, em toneladas, nos principais estados produtores entre os anos de 2000 e 2007.

Tabela 2. Quantidade produzida de tomates (em toneladas) - maiores estados produtores: 2000 a 2007

\begin{tabular}{lcccccccc}
\hline \multicolumn{1}{c}{$\begin{array}{c}\text { Maiores estados } \\
\text { podutores de tomate }\end{array}$} & \multicolumn{7}{c}{ Anos } \\
\cline { 2 - 8 } & 2000 & 2001 & 2002 & 2003 & 2004 & 2005 & 2006 \\
\hline Goiás & 712.448 & 742.182 & 951.410 & 1.016 .188 & 871.945 & 776.430 & 759.620 & 801.960 \\
Säo Paulo & 709.060 & 625.630 & 765.990 & 764.900 & 749.750 & 747.030 & 672.330 & 763.227 \\
Minas Gerais & 532.380 & 626.580 & 637.219 & 689.275 & 622.339 & 617.544 & 552.677 & 421.455 \\
Rio de Janeiro & 193.328 & 197.398 & 163.124 & 173.029 & 203.228 & 209.131 & 212.631 & 196.824 \\
Bahia & 170.653 & 195.275 & 237.763 & 207.365 & 193.203 & 200.436 & 250.986 & 211.727 \\
Paraná & 116.092 & 137.509 & 168.865 & 165.394 & 161.378 & 185.299 & 180.014 & 310.338 \\
Pernambuco & 89.227 & 96.609 & 207.736 & 152.744 & 162.469 & 181.373 & 168.501 & 165.278 \\
Santa Catarina & 115.402 & 125.201 & 127.350 & 129.096 & 129.054 & 123.239 & 119.992 & 136.764 \\
Rio Grande do Sul & 102.757 & 98.660 & 102.156 & 98.634 & 97.846 & 91.001 & 99.694 & 104.981 \\
Bspírito Santo & 95.289 & 99.433 & 109.539 & 118.109 & 125.383 & 123.961 & 132.127 & 112.467 \\
Ceará & 88.348 & 79.372 & 95.945 & 101.280 & 101.264 & 94.482 & 103.291 & 97.295 \\
Distrito Federal & 16.503 & 16.120 & 15.404 & 14.680 & 15.210 & 18.978 & 18.466 & 26.563 \\
Paraíba & 16.157 & 12.000 & 14.941 & 15.165 & 16.136 & 21.672 & 23.325 \\
Rio Grande do Norte & 7.290 & 7.045 & 11.178 & 12.610 & 17.543 & 11.776 & 16.674 \\
\hline
\end{tabular}

Fonte: IBGE (2009). Elaboraçāo dos autores.

Figura 7: Quantidade de tomate produzida (em toneladas) nos principais estados produtores entre os anos de 2000 e 2007 (apud DIEESE, 2010).

A Tabela 4 apresenta os dados nacionais mais recentes sobre a produção e a área plantada de tomates. Os números das safras de 2015 e 2016 aparecem por estado.

Sobre a produção nacional de tomate, Neto afirma que:

O estado de São Paulo é o maior produtor de tomate para mesa, enquanto Goiás é o maior produtor de tomate industrial, sendo responsável por cerca de 80\% da produção nacional total. Em 2011, a Companhia de Entrepostos e Armazéns Gerais de São Paulo (Ceagesp) teve um volume comercializado de tomate tipo salada de 300 mil toneladas. Nas Centrais de Abastecimento (Ceasa) de Goiás, o tomate tem se mantido como o produto mais comercializado, aproximando-se de 90 mil toneladas. (NETO, 2014, p. 17) 
Tabela 4: Área plantada e produção de tomate no Brasil em 2015 e 2016.

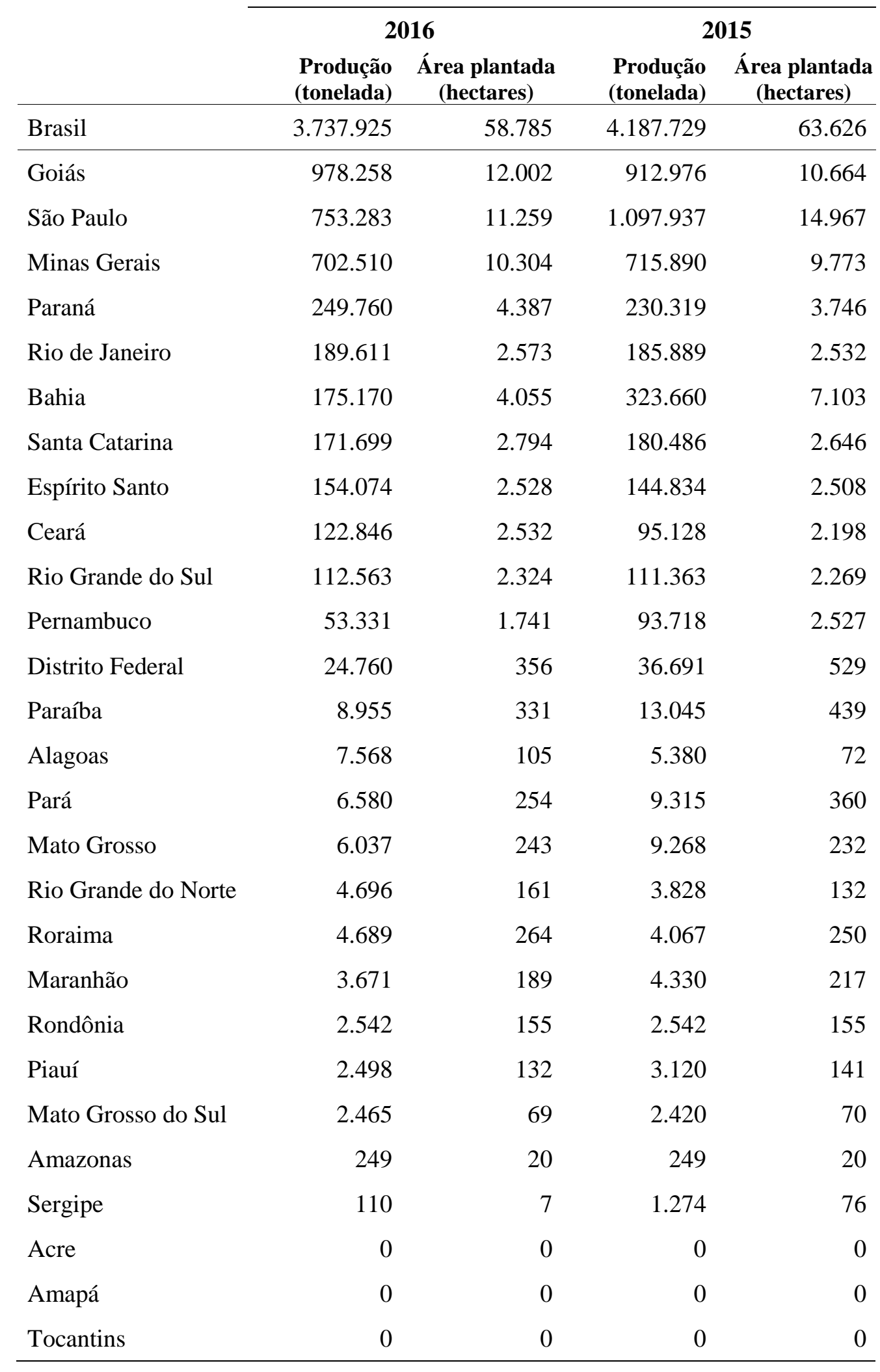

Fonte: IBGE. Levantamento sistemático da produção agrícola, 2016. Org.: Lucinei Paes de Lima, 2017. 
Segundo dados do Centro de Estudos Avançados em Economia Aplicada - Cepea (SILVA; MARTINI, 2006, p. 6), em 2006 a produtividade média das lavouras era de 200 cx/mil pés de tomate. No entanto, com o aumento do uso de insumos, obtém-se rendimento superior a $450 \mathrm{cx} / \mathrm{mil}$ pés em alguns períodos da safra. Segundo os médios produtores de tomate de Ribeirão Branco, o Cepea mantém um canal direto entre seus analistas e produtores associados, atualizando diariamente a cotação de diversos produtos, além de produzir estatísticas para as próximas safras. Desse modo, os médios e grandes produtores são abastecidos com informações para garantirem o melhor mercado para os seus produtos, dentre eles, o tomate.

A Figura 8 consta de um documento de apresentação da Embrapa (VILELA, 2009) sobre a produção de tomates no estado de São Paulo: produção em toneladas, área utilizada para o plantio e quantidade produzida por hectare. Observamos que o município de Ribeirão Branco aparece em primeiro lugar no ranking de principais produtores do estado.

\section{PRINCIPAIS PRODUTORES DE TOMATE DE SÃO PAULO}

São Paulo : $770.804 \mathrm{t}$ - ha $11.234-68,61 \mathrm{t} / \mathrm{ha}$

Mapeamento de $76,12 \%$ da produção

Ribeirão Branco 87.400 t -920 ha- - 95,00 tha

Apiai: $71.500 \mathrm{t}-890$ ha- $-80,3$ tha

Capão Bonito :6.600t-110ha $58.900 \mathrm{t}-620 \mathrm{ha}-\mathrm{t} / \mathrm{th} 95,00 \mathrm{t}$ tha

tha Guaira:41.455 t-449 ha- $-92,33$ tha

Guapiara: $38.352 \mathrm{t}-520 \mathrm{ha}--73,75$ tha

Mogi Guaçu: $36.480 \mathrm{t}-540 \mathrm{ha}--67,56 \mathrm{t} / \mathrm{ha}$

Elias Fausto: 19.250 t- 350 ha- $-55,00$ tha

Itapeva: $17.500 \mathrm{t}-250 \mathrm{ha}-\mathrm{t} / \mathrm{th} 70,00 \mathrm{t} / \mathrm{ha}$

Novo Horizonte :17.300 t-200 ha- - 86,50 tha

Nova Campina: $16.800 \mathrm{t}-280 \mathrm{ha}--60,00$ tha

Barra do Chapéu: 10.500 t-120 ha- $-87,50$ tha

Borborema: $10.080 \mathrm{t}-120$ ha- $-84,00$ tha

Buritizal: $9.760 \mathrm{t}-200 \mathrm{ha}--48,80 \mathrm{t}$ ha

Pacaembu: 9.600 t- 120 ha - 80,00 tha

Hortolândia: 9.550 t-180 ha- - 53,06 tha

- Sumaré: $9.550 \mathrm{t}-180 \mathrm{ha-}-53,06 \mathrm{t} / \mathrm{ha}$

Monte Mor: $8.910 \mathrm{t}-120$ ha- $-74,25 \mathrm{t} / \mathrm{ha}$

Andradina: $8.500 \mathrm{t}-100$ ha- $-85,00$ tha

Santo Antônio da Alegria: 8.350 t-73 ha- - 114,38 t/ha

Porto Feliz: $8.250 \mathrm{t}-150$ ha- $-55,00 \mathrm{t} / \mathrm{ha}$

Araçatuba: $8.000 \mathrm{t}-100 \mathrm{ha}--80,00 \mathrm{t} / \mathrm{ha}$

Mariápolis: 8.000 t-100 ha- $-80,00$ tha

Sales: $7.360 \mathrm{t}-80$ ha- $-92,00 \mathrm{tha}$

Rubiácea: 7.200 t- 72 ha- - 100,00 tha

Guararapes: $7.000 \mathrm{t}-100 \mathrm{ha}--70,00 \mathrm{t} / \mathrm{ha}$

Alto Alegre : $6.910 \mathrm{t}-115$ ha- $-60,09$ tha

Buri: $6.500 \mathrm{t}-100$ ha- $-65,00 \mathrm{t} / \mathrm{ha}$

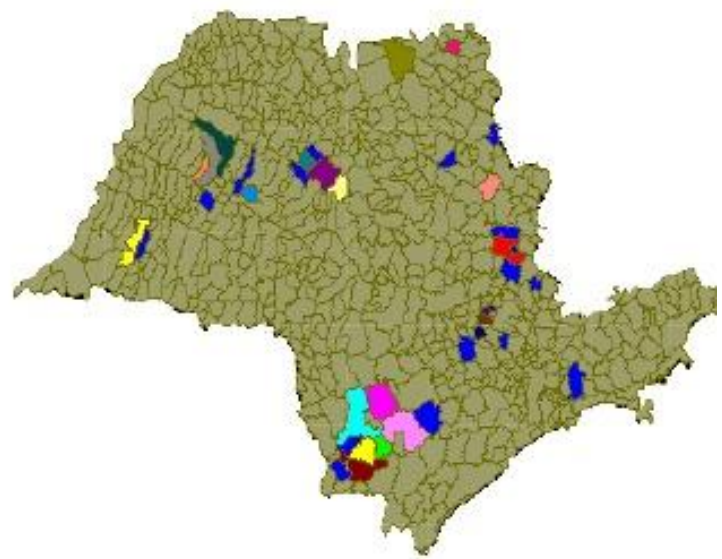

Fonte: IBGE, 2010 ( Pesquisa Agrícola Municipal, 2008)

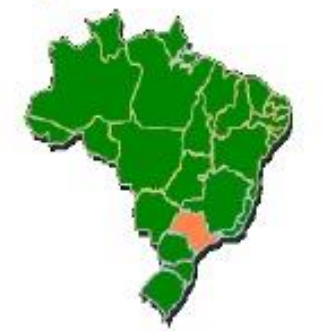

Mapa:IBGE

Figura 8: Principais produtores de tomate do estado de São Paulo (apud VILELA, 2009). 
Distribuição Geográfica de área cultivada e número de produtores, 2007/2008

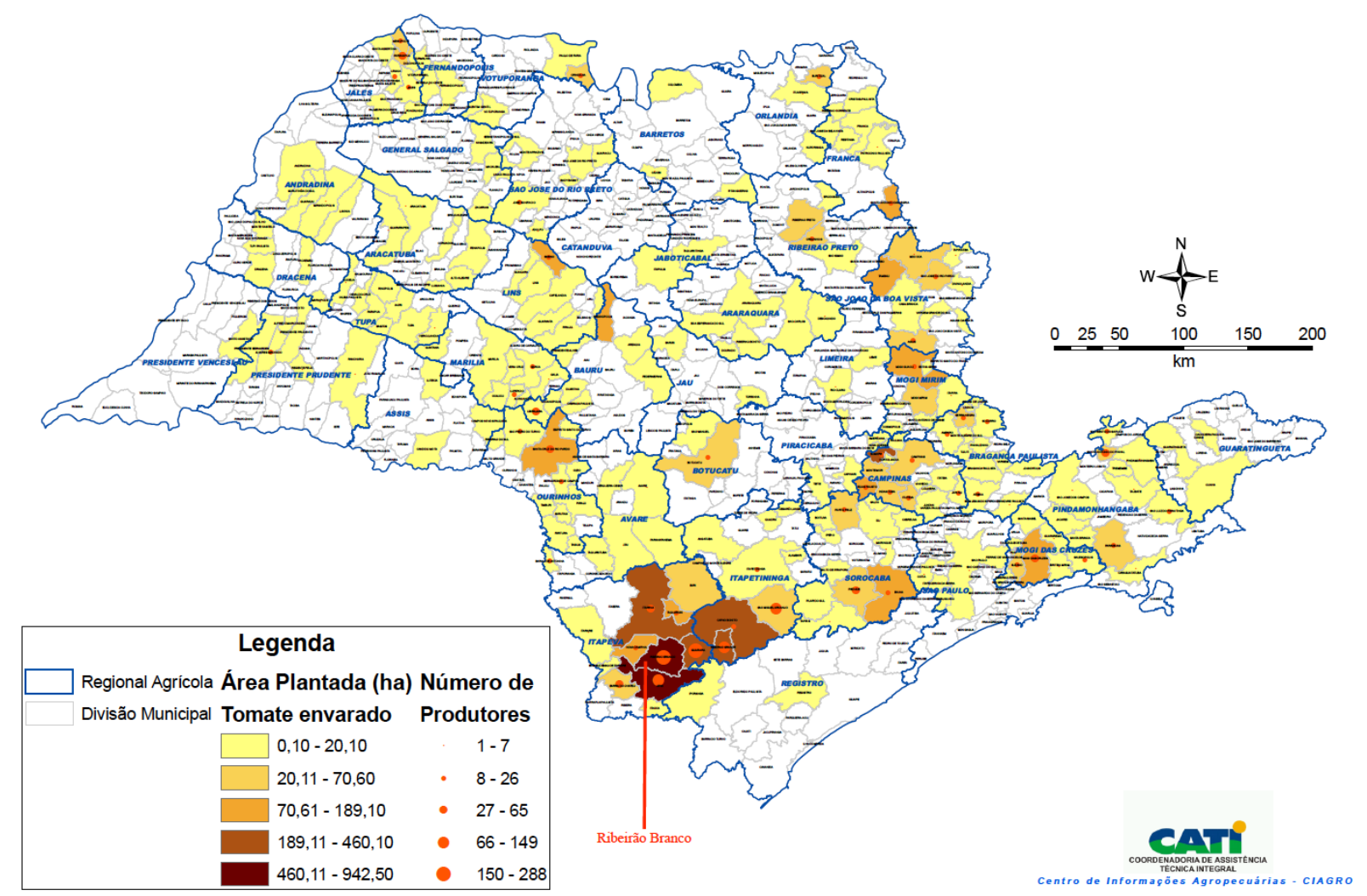

Fonte: Instituto de Economia Agrícola (SÃO PAULO, s.d.a).

Figura 9: Distribuição geográfica e número de produtores de tomate envarado no estado de São Paulo.

Os dados do Instituto de Economia Agrícola (IEA) do governo do Estado de São Paulo (Figura 9 e Tabela 5) reafirmam a liderança da região de Itapeva na produção estadual de tomates.

Os dados da Figura 10 indicam a produção nacional de tomate entre os anos de 2014 e 2016, conforme as safras de cada região. Na terceira coluna da tabela, encontramos os dados referentes à produção da região de Itapeva, onde está localizado o município de Ribeirão Branco. Esses dados demostram a liderança dessa região no ranking de maiores produtores nacionais de tomate. 
ESTATÍSTICA DE PRODUÇÃO - TOMATE*

"As estatísticas de produção divulgadas pelo Cepea não representam a área total cultivada em cada regiào.

Os dados refletem a opiniāo dos principais agentes do setor e são considerados as principais referências de mercado.

\begin{tabular}{|c|c|}
\hline \multicolumn{2}{|c|}{ Tomate de Mesa - Primeira parte da safra de inverno } \\
\hline Regiăo & Praças de Coleta \\
\hline Mogi Guaçu (SP) - abril a outubro & $\begin{array}{l}\text { Estiva Gerbi, Santo Antônio da Alegria, } \\
\text { Aguai, Mogi Guaçu, Mogi Mirim, Serra Negra e Pirassununga }\end{array}$ \\
\hline Sumaré (SP) - maio a junho & $\begin{array}{l}\text { Sumaré, Nova Odessa, Monte Mor, } \\
\text { Elias Fausto, Capivari e Indaiatuba }\end{array}$ \\
\hline Araguari (MG) - março a novembro & Araguari, Indianápolis, Uberaba, Monte Carmelo e Catalão \\
\hline Pará de Minas (MG) - abril a novembro & $\begin{array}{l}\text { Carmópolis, Pitangui, Onça do Pitangui, Barbacena, } \\
\text { Carandai, Coimbra e São José da Varginha }\end{array}$ \\
\hline São José de Ubá (RJ) - junho a outubro & $\begin{array}{l}\text { Aré, São Joāo do Paraiso, Itaperuna, } \\
\text { Bom Jesus e São José de Ubá }\end{array}$ \\
\hline Itaocara $(\mathrm{RJ})$ - maio a novembro & Itaocara \\
\hline Paty do Alferes (RJ) - abril a agosto & Paty do Alferes, Vassouras e Paraiba do Sul \\
\hline Norte do Paraná - março a junho & $\begin{array}{l}\text { Wenceslau Braz, São Jerônimo da Serra, } \\
\text { Mauá da Serra, Faxinal, Londrina e Marilândia do Sul }\end{array}$ \\
\hline Sul de Minas Gerais - abril a agosto & $\begin{array}{l}\text { Conceição do Rio Verde, Conceiçāo das Pedras, Três Coraçōes, } \\
\text { Itajubá, Pouso Alegre, São Gonçalo, Poço Fundo, Alfenas, } \\
\text { Machado, Três Pontas, Coqueiral, Santana da Vargem, } \\
\text { Boa Esperança, Campo do Meio, Pomuceno e Campos Gerais }\end{array}$ \\
\hline Venda Nova do Imigrante (ES) - julho a dezembro & Venda Nova do Imigrante \\
\hline
\end{tabular}

\begin{tabular}{|c|c|c|}
\hline \multicolumn{3}{|c|}{ Número de pés (milhōes) } \\
\hline 2014 & 2015 & Variação (\%) \\
\hline 8,00 & 8,00 & $0 \%$ \\
\hline 2,80 & 2,80 & $0 \%$ \\
10,00 & 10,00 & $0 \%$ \\
\hline 4,50 & 4,20 & $-7 \%$ \\
\hline 3,60 & 2,00 & $-44 \%$ \\
2,00 & 1,50 & $-25 \%$ \\
4,50 & 4,50 & $0 \%$ \\
1,80 & 1,20 & $-33 \%$ \\
& & \\
6,00 & 6,00 & $0 \%$ \\
\hline 10,00 & 10,00 & $0 \%$ \\
\hline
\end{tabular}

\begin{tabular}{|c|c|}
\hline \multicolumn{2}{|c|}{$\begin{array}{c}\text { Tomate de Mesa - Segunda parte da safra de inverno } \\
\text { Região }\end{array}$} \\
\begin{tabular}{|c|c|} 
Praças de Coleta \\
\hline Sumaré (SP) - outubro a dezembro
\end{tabular} & $\begin{array}{c}\text { Sumaré, Nova Odessa, Monte Mor, } \\
\text { Elias Fausto, Capivari e Indaiatuba }\end{array}$ \\
\hline Paty do Alferes (RJ) - setembro a dezembro & $\begin{array}{c}\text { Paty do Alferes, Vassouras e Paraíba do Sul } \\
\text { Wenceslau Braz, São Jerônimo da Serra, }\end{array}$ \\
\hline Norte do Paraná - setembro a dezembro & $\begin{array}{c}\text { Mauá da Serra, Faxinal, Londrina e Marilândia do Sul } \\
\text { Sul de Minas Gerais - setembro a dezembro }\end{array}$ \\
$\begin{array}{c}\text { Conceição do Rio Verde, Conceição das Pedras, Três Coraçố, } \\
\text { Itajubá, Pouso Alegre, São Gonçalo, Poço Fundo, Alfenas, } \\
\text { Machado, Três Pontas, Coqueiral, Santana da Vargem, } \\
\text { Boa Esperança, Campo do Meio, Pomuceno e Campos Gerais }\end{array}$ \\
\hline
\end{tabular}

\begin{tabular}{|c|c|c|}
\hline \multicolumn{3}{|c|}{ Número de pés (milhōes) } \\
\hline 2014 & 2015 & Variação (\%) \\
\hline 2,15 & 2,00 & $-7 \%$ \\
4,50 & 4,00 & $-11 \%$ \\
1,10 & 1,20 & $9 \%$ \\
& & \\
4,00 & 4,00 & $0 \%$ \\
\hline
\end{tabular}

\begin{tabular}{|c|c|}
\hline \multicolumn{2}{|c|}{ Tomate de Mesa - Safra de verão } \\
\hline Regiāo & \\
\hline Itapeva (SP) - novembro a maio & $\begin{array}{c}\text { Itapeva, Guapiara, Apiaí, Capâo Bonito, Itaberá, Buri, } \\
\text { Taquarivaí e Ribeirāo Branco }\end{array}$ \\
\hline Caçador (SC) - dezembro a abril & 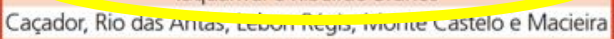 \\
\hline Urubici (SC) - dezembro a abril & Urubici \\
\hline Venda Nova do Imigrante (ES) - novembro a junho & Venda Nova do Imigrante \\
\hline Nova Friburgo (RJ) - dez a abril & Bom Jardim, Sumidouro e Teresópolis \\
\hline Reserva (PR) - novembro a abril & Reserva, Ortigueira e Imbaú \\
\hline Caxias do Sul (RS) - novembro a maio & $\begin{array}{l}\text { Caxias do Sul, Nova Petrópolis, Nova Bassano, } \\
\text { Pelotas, Nova Prata, Santa Lúcia do Piaí }\end{array}$ \\
\hline $\begin{array}{l}\text { Agreste de Pernambuco - } \\
\text { concentra de setembro a março }\end{array}$ & $\begin{array}{l}\text { Gravatá, Bezerros, Sairé, Camocim do São Felix, } \\
\text { São Joaquim do Monte Bonito e Caruaru }\end{array}$ \\
\hline
\end{tabular}

\begin{tabular}{|c|c|c|}
\hline \multicolumn{3}{|c|}{ Número de pés (milhões) } \\
$2014 / 15$ & $2015 / 16$ & Variação (\%) \\
\hline 27,00 & 27,00 & $0 \%$ \\
11,50 & 11,50 & $0 \%$ \\
2,60 & 3,10 & $19 \%$ \\
10,00 & 10,00 & $0 \%$ \\
5,50 & 5,00 & $-9 \%$ \\
8,00 & 8,00 & $0 \%$ \\
10,50 & 10,50 & $0 \%$ \\
11,00 & 8,50 & $-23 \%$ \\
& & \\
\hline
\end{tabular}

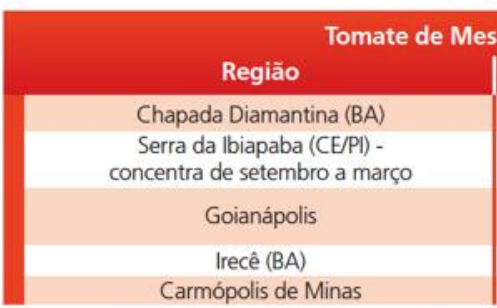

\section{sa - Safra Anual}

\begin{tabular}{|} 
Praças de Coleta \\
Alto Paraguaçú \\
Guaraciaba, Sảo Benedito, Ibiapina, Ubajara, \\
Tiangua, Viçosa do Ceara, Ipu e Carnaubal \\
Corumbá, Cocalzinho, Pirinópolis, \\
São Joăo da Aliança, Goianápolis \\
Região de Irecê e Região de Seabra \\
Carmópolis de Minas
\end{tabular}

Obs: Os dados se referem apenas ao plantio do tomate destinado à mesa.

\begin{tabular}{|c|c|}
\hline \multicolumn{2}{|c|}{ Tomate Rasteiro/Indústria } \\
\hline Regiāo & Praças de Coleta \\
\hline \multicolumn{2}{|l|}{ Estado de Goiás } \\
\hline Estado de São Paulo & Matão e Araçatuba \\
\hline Estado de Minas Gerais & Paracatu e Lagoa Grande \\
\hline Agreste de Pernambuco & $\begin{array}{l}\text { Gravatá, Bezerros, Sairé, Camocim de São Félix, } \\
\text { São Joaquim do Monte, Bonito e Caruaru }\end{array}$ \\
\hline
\end{tabular}

\begin{tabular}{|c|c|c|}
\hline \multicolumn{3}{|c|}{ Número de pés (milhões) } \\
$2014 / 15$ & $2015 / 16$ & Variação (\%) \\
\hline 12,00 & 9,00 & $-25 \%$ \\
13,00 & 11,20 & $-14 \%$ \\
23,00 & 23,00 & $0 \%$ \\
20,00 & 16,00 & $-20 \%$ \\
4,00 & 4,00 & $0 \%$ \\
\hline
\end{tabular}

Figura 10: Produção nacional de tomates de 2014 a 2016 (apud CEPEA, 2016, p. 21). 
Tabela 5: Produção paulista de tomate envarado na safra de $2015^{6}$.

\begin{tabular}{lrr}
\hline Região administrativa & $\begin{array}{c}\text { Área plantada } \\
\text { (hectares) }\end{array}$ & $\begin{array}{c}\text { Produção } \\
\text { (caixas de 25 kg) }\end{array}$ \\
\hline Itapeva & $5.002,00$ & $16.272 .100,00$ \\
Campinas & $1.613,10$ & $3.810 .528,00$ \\
Sorocaba & 550,50 & $1.180 .360,00$ \\
Bauru & 200,40 & $743.882,00$ \\
São José do Rio Preto & 240,98 & $591.638,00$ \\
Marília & 148,30 & $568.620,00$ \\
Ribeirão Preto & 106,00 & $285.300,00$ \\
São José dos Campos & 118,30 & $266.660,00$ \\
Presidente Prudente & 91,50 & $178.900,00$ \\
São Paulo & 76,50 & $177.500,00$ \\
Araçatuba & 36,10 & $56.868,00$ \\
Central & 20,30 & $54.733,00$ \\
Franca & 18,00 & $36.360,00$ \\
Registro & 0,10 & 80,00 \\
\hline
\end{tabular}

Fonte: Instituto de Economia Agrícola (SÃO PAULO, s.d.c). Org.: Lucinei Paes de Lima, 2017.

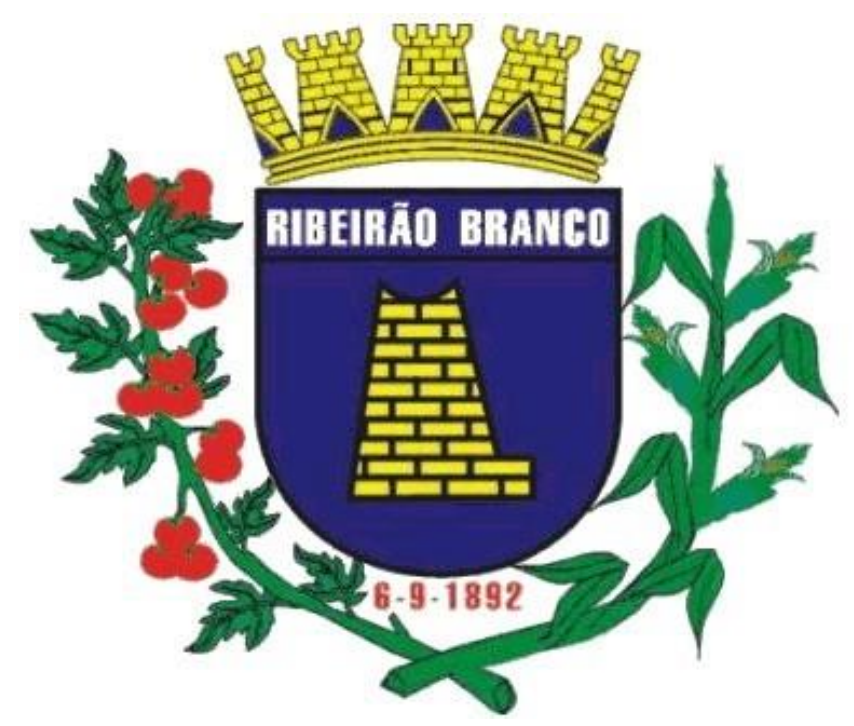

Figura 11: No brasão de Ribeirão Branco, a produção de tomate e milho.

\footnotetext{
${ }^{6}$ Não apresentamos os dados de 2016 porque, no momento da pesquisa, essa safra ainda não havia sido finalizada.
} 


\section{A produção capitalista em Ribeirão Branco: a monocultura do tomate}

O mote dessa pesquisa é o campesinato, mas, durante o nosso trabalho de campo, além dos dados que chamaram nossa atenção sobre a quantidade de tomate produzida no município, tivemos o contato e a oportunidade de dialogar sobre a produção capitalista desse produto. Assim, consideramos importante apresentar essa realidade, já que iremos tratar desse cultivo feito também pelos camponeses no capítulo seguinte.

Para introduzirmos a produção capitalista, nos remetemos a obra de Marx:

Para os colonos e sobretudo para os pequenos produtores independentes, que não dispõem de capital e só podem obtê-lo a juros excessivos, a parte do produto a qual representa o salário é a respectiva renda, quando para o capitalista é adiantamento de capital. Aqueles, portanto consideram esse emprego de trabalho condição indispensável do produto, e este ocupa o primeiro plano. Mas descontado o trabalho necessário, seu trabalho excedente se realiza seja como for num produto excedente, e, quando o podem vender ou mesmo aplicar, consideram-no coisa gratuita, pois não lhe custou trabalho materializado. Só o dispendido deste constitui para eles alienação de riqueza. Procuram naturalmente vender tão caro quanto possível; mas, para eles sempre é lucro mesmo a venda abaixo do valor e do preço de produção capitalista, desde que a dívida, hipoteca etc., não se antecipem a esse lucro. $\mathrm{O}$ capitalista, ao contrário, considera o emprego de capital variável ou constante, adiantamento de capital. O adiantamento relativamente maior do capital constante, não se alterando as demais condições, reduz o preço de custo e efetivamente também o valor das mercadorias. Em consequência, embora o lucro só derive do trabalho excedente, portanto unicamente do emprego de capital variável, pode não obstante o capitalista individual pensar que o trabalho vivo é dos custos de produção o elemento mais oneroso e que mais importa reduzir ao mínimo. Aí a concepção capitalista apenas deforma algo verdadeiro, a saber, que a aplicação proporcionalmente maior de trabalho pretérito, comparado ao trabalho vivo, significa produtividade acrescida do trabalho social e maior riqueza social. Assim, vistas pelo prisma da concorrência, todas as coisas ficam deformadas e invertidas. (MARX, s.d., p. 791)

Essa longa citação permeia todo esse capítulo, como veremos nas entrevistas realizadas com os produtores capitalistas de tomate.

Como forma de aprofundarmos esse debate, consideramos fundamental acrescentarmos aqui a discussão sobre a terra e a renda da terra, pois, é um assunto que também discutiremos mais adiante quando tratarmos dos camponeses e a difícil trajetória do acesso à terra de trabalho.

No capitalismo, a terra, transformada também em mercadoria, tem um preço, mas não tem valor, porque não é produto criado pelo trabalho humano. A propriedade capitalista da terra é renda capitalizada; é direito de se apoderar de uma renda, que é uma fração da mais-valia social e, portanto, pagamento subtraído da sociedade em geral. Isso ocorre devido ao fato de que uma classe detém a propriedade privada da terra e só permite a sua utilização como meio de produção (arrendada ou não), através da cobrança de um tributo: a renda 
capitalista da terra. É por isso que, sob o capitalismo, a compra da terra é compra de renda antecipada. Quando estamos diante da grilagem de terras, esse processo revela seu verdadeiro caráter: o caminho "gratuito" do acesso à renda, do acesso ao direito antecipado de obter o pagamento da renda, sem mesmo ter sequer pago para poder auferi-la. [...] Portanto, a concentração da terra não é igual à concentração do capital; ao contrário, revela a irracionalidade do método que retira capital do processo produtivo, imobilizando-o sob a forma de propriedade capitalista da terra. (OLIVEIRA, 1986, p. 79-80)

Ou seja, para o capital, é essencial a sujeição da renda da terra para, então, se ter as condições de extrair a mais-valia que se dá nela. Continuamos a perseguir a análise de Oliveira que, de acordo com o referencial marxista, nos leva a compreender as diferentes formas de renda da terra: renda diferencial I e II, renda absoluta e renda de monopólio.

Assim, a renda da terra sob o modo capitalista de produção é, resultado da concorrência, renda diferencial; e é, resultando do monopólio, renda absoluta.

Embora na prática seja difícil distinguir essas duas espécies de renda da terra, cabe esclarecer a essência de cada uma delas. A renda diferencial resulta do caráter capitalista da produção e não da propriedade privada do solo. Já a renda absoluta resulta da posse privada do solo. Já a renda absoluta resulta da pose privada do solo e da oposição existente entre o interesse do proprietário fundiário e o interesse da coletividade; resulta do fato de que a propriedade da terra é monopólio de uma classe que cobra um tributo da sociedade inteira para coloca-la para produzir.

Antes de detalharmos essas duas formas de renda, devemos lembrar que sob o modo capitalista de produção é o preço de produção (custo + lucro médio) do "pior" solo (aquele que não dá renda) o preço regulador do mercado.

A renda diferencial I e II:

Assim, a renda diferencial decorre da diferença entre o preço individual de produção do capital particular que dispõe de uma força natural monopolizada e o preço de produção do capital empregado no conjunto do ramo de atividade considerado.

As causas da renda diferencial são três, sendo que as duas primeiras (renda diferencial I) independem do solo e a localização das terras. Essas duas podem atuar em sentidos opostos. A terceira causa (renda diferencial II) é oriunda dos investimentos de capital no solo para melhorar a sua produtividade e/ ou localização.

Portanto, a renda diferencial resulta do caráter capitalista da produção, ou seja, ela continuaria a existir se o solo fosse nacionalizado. Ela apenas não se reverteria para os seus proprietários e sim para o conjunto da coletividade.

A renda absoluta:

Enquanto isso, a outra forma de renda da terra, a renda absoluta é aquela que resulta do monopólio da terra por uma classe ou fração de classe, e desapareceria caso as terras fossem nacionalizadas. Assim, a renda absoluta é resultante da elevação dos preços dos gêneros alimentícios acima do preço de produção desses gêneros, principalmente por ação dos monopólios. Isso porque os proprietários fundiários só permitem a utilização de suas terras quando os preços de mercado ultrapassam os seus preços de produção. Dessa forma obtêm um lucro extraordinário, que, ao contrário do da renda diferencial, não é fração do trabalho excedente dos trabalhadores daquela terra em particular, mas sim fração da massa de mais - valia global dos 
trabalhadores em geral da sociedade. Um verdadeiro tributo que a sociedade inteira paga aos proprietários da terra.

A renda de monopólio:

Além destas duas espécies de renda da terra, a diferencial e a absoluta, existe ainda a renda de monopólio, que é também lucro suplementar derivado de um preço de monopólio de uma certa mercadoria produzida em uma porção do globo terrestre dotada de qualidades especiais. Exemplo: uma vitivinicultura onde se consegue um vinho de qualidade inigualável (vinho do Porto em Portugal, por exemplo), o qual pode ser produzida em quantidade reduzida, acaba por proporcionar um preço de monopólio. O excedente provocado pela diferença entre o preço de monopólio (aquele que é determinado apenas pelo desejo e pela capacidade de pagamento dos compradores, sem depender do preço geral de produção ou do valor dos produtos) e o valor do produto (quantidade de trabalho necessária para a produção desse produto) é um lucro suplementar; portanto, renda de monopólio. (OLIVEIRA, 1986, p. 74-76)

Segundo Oliveira, devemos considerar que o capitalista tem como referência de preço sempre o pior solo e que busca sempre o lucro extraordinário, acima do lucro médio, ou seja, produto do trabalho excedente, da mais-valia. Acima de tudo, trata-se de uma pequena parte da sociedade que detém a propriedade de extensas porções de terra, gerando uma enorme desigualdade em relação a esmagadora maioria da população rural que se vê obrigada a pagar um tributo para ter acesso à terra e realizar a sua produção de alimentos.

A nossa primeira entrevista sobre a produção capitalista foi com o produtor de tomates e também prefeito da cidade de Ribeirão Branco, Sr. Sandro Sala. Abaixo, destacamos alguns trechos da transcrição realizada:

Lucinei: Prefeito Sandro, como é a produção de tomates para o município de Ribeirão Branco?

Prefeito: É variável, no ano que o pessoal toma prejuízo, no ano seguinte a tendência é sempre reduzir a quantidade de pés plantados. Mas, de uns vinte anos para cá, aumentou consideravelmente a produção no município. Nos últimos anos, o município produziu uma média de 12 milhões de pés de tomate por ano - na região do Sudoeste paulista, a média é de 20 milhões de pés por ano.

Lucinei: Quem produz mais tomate? Os camponeses ou os grandes produtores?

Prefeito: Eu acho que temos um equilíbrio entre a produção dos grandes contra os médios e pequenos. Porque os grandes estão plantando muito aqui. Grande aqui é aquele que planta 600 mil pés cada um, então é muito tomate! Grande é aquele que está estabilizado, que não depende de ninguém, tem capital de giro, tem o lugar certo de vender. Então o grande sobrevive por si. Os pequenininhos têm as linhas de crédito com juros baixos que permitem a ele plantar. Já o médio, que é aquele que planta acima de 50 mil pés, esse ainda está mais desamparado que o pequeno, pois não tem linhas de crédito. (Entrevista com Sandro Sala, jan. 2016)

Na opinião do prefeito Sandro Sala, os médios produtores (como ele) são os que têm menos apoio para a produção de tomates, já que estão entre o poder econômico dos grandes 
produtores e as políticas públicas de incentivo e linhas de crédito a juros baixos, como o Programa Nacional de Fortalecimento da Agricultura Familiar (Pronaf) e os programas de vendas institucionais, como o Programa de Aquisição de Alimentos (PAA) e o Programa Nacional de Alimentação Escolar (Pnae), destinadas aos pequenos produtores. Adiante, o nosso interlocutor diz quem seriam os grandes, médios e pequenos produtores no município.

Lucinei: Quem são os grandes produtores aqui no município?

Prefeito: Aqui os maiores produtores do município são famílias que montam as suas próprias empresas, tipo Irmãos Oliveira, empresa Condor e Santa Bárbara, família Guedes.

Esses, como têm capital para investir, eles plantam e colhem três lavouras de tomates durante o ano aqui no município. Enquanto os médios plantam no máximo duas lavouras (dois ciclos diferentes) e o pequeno produtor planta só uma lavoura no ano.

O grande começa a colher em novembro e termina em maio então ele tem tomate no nosso ciclo, o médio vai ter uma colheita de noventa dias e o pequenininho vai ter só um ciclo dos três que temos, o que equivale a quarenta dias de colheita no máximo para ele. Se pegar por aí, dá para diferenciar o grande do médio do pequeno.

Lucinei: Existe uma diferença muito grande no resultado da produção do pequeno e do grande produtor?

Prefeito: Considero que os três (pequeno, médio e grande) produzem parecido, uma média de trezentas caixas por mil pés de tomate. Não acho que o pequeno fique muito atrás disso hoje não. A diferença é que o grande fabrica a sua própria caixa, e cada caixa vai cerca de $18 \mathrm{~kg}$, e então o tomate dele é muito difícil não atingir quinhentas caixas por mil pés, né? Pois vai menos tomate na caixa dele! Os demais, os outros vendem em outra caixa, que dá até $26 \mathrm{~kg}$ cada uma, e colhe então trezentas. Mas, em termos de quantidade produzida, considero que é equivalente. (Idem)

Aqui o prefeito aponta uma diferença favorável ao grande produtor na comercialização do produto, já que esse tem os mecanismos que tornam a sua atividade mais rentável, quando cita, como exemplo, o fato de que, como o pequeno produtor vende a sua produção para o atravessador, ele tem que utilizar o padrão de classificação e a embalagem fornecida pelo atravessador. Essa caixa, na maioria das vezes, é maior que aquela utilizada na venda direta, pois a intenção do atravessador é classificar e embalar novamente o produto para revender.

Ressaltamos que o grande produtor faz a venda direta da sua produção e, com isso, além de eliminar o atravessador, também fabrica a sua própria caixa (menor e já no padrão da entrega final), compra insumos mais baratos e tem o seu próprio transporte. Juntando todos esses fatores fica evidente a vantagem do grande produtor. Abaixo, mais um trecho da entrevista:

Lucinei: Para onde é transportado o tomate de Ribeirão Branco?

Prefeito: O nosso tomate vai pra todo canto. Esse ano, por exemplo, vai pro sul, Curitiba, Goiás, Distrito Federal, interior de São Paulo... todos os Ceasas do estado de São Paulo recebem o nosso tomate. Até vai para Maranhão, Bahia, Cuiabá, mas daí é menos, não compensa muito longe. 
Lucinei: Nos disseram que o inverno aqui costuma ser rigoroso e há dificuldades de produzir nesse período. Como a população sobrevive até a chegada da próxima safra?

Prefeito: Nós aqui em Ribeirão somos igual formiga, trabalhamos no verão pra comer no inverno. Trabalhamos seis meses intensamente e os outros seis ficamos vivendo dos resultados do primeiro. Essa é a verdade.

Então, o ano que dá boa a safra de tomates, o povo resolve renovar as cercas, arrumar implementos agrícolas que estão precisando de manutenção. Já o ano que não tem dinheiro, todo mundo passa empurrando com a barriga e a economia local sente o reflexo disso.

O problema aqui é que o inverno é muito rigoroso, então plantar pra comercializar não dá, é muito arriscado. Quem tem a sua terra ainda tem ali um gadinho, um capãozinho de eucalipto. Então ele tem uma renda extra, uma espécie de poupança que ele faz. Principalmente o pequenininho, hoje, principalmente, você pode andar aqui pelo município, pega um bairro onde o pequeno tem a sua terra, esse povo está muito mais capitalizado do que os médios, sabia? Você pode observar, esse povo vem pra cidade e compra as suas coisas tudo à vista, tudo no dinheiro. Como o médio tem que pagar mão de obra e o pequeno não, e hoje a mão de obra no tomate dá $50 \%$ dos gastos, então para ele [o pequeno] sai livre. Então, eles estão muito melhor de situação porque eles pegaram... tão vindo de um ciclo do tomate aqui que não tá vindo ruim ultimamente. Tem uns quatro a cinco anos pra cá que o povo tem ganho dinheiro. Às vezes não dá muito bom pro médio, e dá até ruim pela mão de obra, mas ainda assim você acredita que o pequeno consegue ainda ganhar dinheiro? Tem muito pequeno que está bem de vida aí.

Lucinei: Você também é produtor, você considera o tomate uma produção de alto risco? Qual seria o motivo da escolha pelo plantio de tomates no município?

Prefeito: Acho que o município todo planta muito tomate porque é um produto que vende, esteja barato ou caro, todo mundo come, tomate tem grande consumo. Outro ponto é o ciclo dessa lavoura, que é curto. Você pega a economia esse ano, por conta da alta do dólar, vai ficar em 7 reais por pé e, no ano passado, era em torno de 5 reais o pé [custo de produção por pé]. Só que tivemos contratempos em outras regiões, a seca diminui o tomate rasteiro no estado de Goiás e teve período que só a nossa região tinha tomate. Estamos vendendo tomate a 60, 70 reais a caixa desde o final de novembro de 2015, pra você ter uma ideia. Não tem como não ganhar dinheiro nesse preço! Tá todo mundo contente, vê se alguém tá xingando o prefeito? Ninguém tá lembrando do prefeito! Mas foi isso, os contratempos.

Mas olha, só teve gente que mesmo assim quebrou, teve gente grande que quebrou e outro que plantou do mesmo jeito na mesma safra e enricou! Agora você me pergunta como pode? Esse é o segredo que ninguém sabe responder! $\mathrm{O}$ jeito de trabalhar e administrar? Não sei, porque ambos venderam no mesmo preço! Como um quebra e outro fica rico?

Lucinei: Você pode dar um exemplo?

Prefeito: A empresa da família Finêncio [empresa Condor] triplicou o seu patrimônio. O pai sempre plantava 150 mil pés, depois veio o filho, foi num ano que todo mundo quebrou com tomate. Deu ruim demais o preço naquele ano. Mas esse menino tinha uma reserva de dinheiro e, então, ele percebeu que ninguém teria como expandir a produção, pelo contrário, estavam diminuindo a quantidade de pés. Aí ele aumentou e duplicou, de 150 foi pra 300 mil pés, isso em cada ciclo, e então chegou a 4 milhões de pés durante o ano. Ele fez dinheiro que nem água! Passou os três ciclos [três períodos de roças durante o ano] vendendo tomate entre 80 e 90 reais a caixa. Então hoje 
ele tem um dinheiro que não acaba mais! Disseram que ele comprou várias fazendas, inclusive chegou a emprestar dinheiro para multinacional Elite! Olha, esses caras grandes são assim, se qualquer um de nós estivermos com um caminhão encostado carregando adubo numa empresa, se chegar um caminhão de um desses grandes aí, a loja para no meio o seu carregamento e vai carregar o dele primeiro! A gente espera na fila.

Lucinei: Então dá para ganhar dinheiro com o tomate?

Prefeito: Olha, aqui em Ribeirão a grande ilusão é o tomate, porque você faz a conta e dá muito dinheiro! Pega... hoje tá 80 a 90 reais a caixa, hoje, então vamos fazer uma conta: pega 150 mil pés... se você colher uma produção de 300 por mil [trezentas caixas a cada mil pés de tomates plantados], que é a média... Dá mais até, mas vamos fazer a média por baixo! Então você vai colher 45 mil caixas de tomate.

Então, 45 mil caixas vezes o preço do dia... bom, nem vou colocar aqui o preço de hoje, que é 80, 90 reais, vamos colocar uma média, então, de 50 reais durante toda a colheita nesse preço. Então você vai ter, de venda, 2,5 milhões de reais, vai tirar o custo de 7 reais por pé, que fica no total de 1 milhão. Então, de 2,5 milhões, você retira o custo de 1 milhão, então você lucrou o valor de 1,5 milhão numa roça dessa! Tá vendo? Se você faz essa conta, fica com vontade de plantar!

Mas veja, o risco é muito alto. Já aconteceu mesmo comigo, de eu vender tomate a 10 reais a caixa e só via os boletos de contas chegarem, e nada entrando, aí dá aquele desespero! Você vai vendo o tomate acabando na sua roça e o preço nada de subir!

Mas o tentador é que, se você pensar que se você vender o tomate a 70 reais a caixa, então quer dizer que se você colocar seiscentas caixas num caminhão pra vender, isso vai dar um valor de 42 mil reais, isso num curto prazo que é a lavoura de tomates, é rapidinho você faz esse dinheiro.

Para os grandes produtores, tem a vantagem que eles percebem a maré boa para produzir o seu tomate e aí eles têm dinheiro a qualquer momento e podem aumentar a plantação olhando para essa maré boa.

Lucinei: E como faz para perceber se a maré está boa e se vai dar preço?

Prefeito: Ah, a gente sente, dá pra sentir! Hoje a informação é muito rápida. Hoje tem o Cepea que trabalha com pesquisa com tomate. Lá cada equipe cuida de um produto. Aí eles pesquisam todas as regiões do Brasil e faz estimativa, vai ter aumento de $10 \%$ ? Qual região deve aumentar? Eles fazem estudo todos os dias e aí, se você é cadastrado, eles passam informação no seu celular todos os dias sobre o mercado como está. Então todos sabem quanto pegou o preço do tomate em todos os mercados do Brasil.

$\mathrm{O}$ pequenininho não tem essa informação, mas o médio e o grande têm informação diária. Aí um grande vê que deu bom tomate, um Goiânia aí, ele já se articula e manda naquele dia o tomate dele pra lá. Já o pequenininho não pode fazer isso e tem que entregar tudo para um mesmo comprador, e ainda dá graças por ter um que tope ir lá na roça dele carregar o tomate dele. $\mathrm{O}$ grande entrega onde ele quiser, onde está o preço melhor, ele leva. (Idem)

Nesse trecho da entrevista, o prefeito fala sobre a excitação que a plantação de tomates causa por conta da probabilidade de se obter altos lucros em um curto espaço de tempo. Também aborda o préstimo que os grandes produtores têm e que lhes garante vantagens - por exemplo, o uso de institutos de pesquisa contratados para assessorar e disponibilizar dados sobre a melhor época para plantio e o melhor mercado do dia para entregar os seus produtos. 
Lucinei: Você mencionou a mão de obra utilizada pelos médios e grandes produtores e disse que o camponês tem essa vantagem de não precisar pagar pela mão de obra porque utiliza o trabalho da sua família. Como é calculado esse valor de mão de obra?

Prefeito: Veja bem, primeira coisa, o pequeno tem a vantagem de que, para produzir o tomate, se usa pouca terra. Então qualquer um pode produzir tomates. Por exemplo, aqui em Ribeirão Branco, usamos produzir 30 mil pés de tomate por alqueire, é o que ocupa de espaço. Então é pouca terra que usa! Agora, veja bem, pra você ver... o pequeno, ele tem mais vantagem no preço final do seu produto por causa da mão de obra que ele não paga.

Veja que se o grande vender a caixa de tomate por 80 reais, como está hoje, no nosso cálculo disso, ele tem que tirar os custos com insumos e mão de obra. Já o pequeno, se ele vende por menos que 80 reais, ainda assim ele vai quase empatar aqui, vai ficar quase igual. Porque o custo é menor, ele tem a mão de obra, mas é dele e ele paga pra ele mesmo esse dinheiro fica com ele mesmo! Lucinei: Como é feito o cálculo dos custos de uma lavoura de tomate?

Prefeito: Então, é assim: metade do custo é mão de obra e a outra metade é os insumos. De 6 a 7 reais por pé de tomate é o custo. Vamos falar de 6 reais. Então, fica 6 mil reais para produzir cada mil pés de tomate, certo? Então uma roça de 100 mil pés vai gastar 600 mil reais. Aí você pega e separa: 300 mil é gasto com mão de obra e outros 300 é gasto com insumos.

É tudo uma média porque, no meio disso, tem que considerar que no início da roça saem os tomates melhores, mais graúdos e bonitos e, por fim, os mais feios, que pegam preços diferentes. Mas o que vale é a média final e não só vender no dia de hoje a caixa por 80 reais. E o resto? A conta correta é a conta final, a média final da sua lavoura.

Lucinei: Tem que vender a partir de quanto pra começar a ganhar dinheiro com esse custo de produção?

Prefeito: Olha, a média dessa safra é de 30 reais, acima disso você já começa a ganhar dinheiro. Se vender nessa safra ao valor de 20 reais é só para pagar a conta, mas aí você tem que pensar que precisa também pagar as despesas com os desgastes dos seus maquinários, que eu coloco mais uns 5 reais a mais tem pneus, peças, etc. Veja só, no ano passado, com 20 reais a gente já teve lucro.

Sabe, o que eu não entendo é que tudo é vendido por quilo, vende pão por quilo, banana por quilo, laranja e até cebola na roça já se vende por quilo, já o tomate aqui vendemos por caixa e não por quilo! Isso precisa mudar!

Os grandes têm essa vantagem, os grandes pesam o caminhão antes de vender e nós não! Nós entregamos na caixa grande, o comprador passa na caixa menor dele e vende. Deveria ser lei de passar na balança o tomate de todos na hora de vender, pois a gente perde muito com isso. Se fosse por quilo, dava muito mais.

Mas o problema é que o Ceasa existe é pra os grandes, está preparado pro grande chegar e usar. Mas está errado, os médios e pequenos é que eram pra estar lá vendendo o seu produto. Isso está errado. Do jeito que está, penaliza os municípios produtores porque, nos Ceasas, a fiscalização é toda precária. Sabia que quem mais sonega notas são os plantadores de verdura? O nosso produto vai no Ceasa, os caras molham a mão do porteiro e, por exemplo, esses Ceasas do interior, é uma nota por mês que eles destacam pra quem vende pra feirante, só tira pra quem vende pra mercados mesmo! Isso é sonegação de impostos! (Idem)

Aqui o Sr. Sandro detalha os custos da produção de tomates e compara a situação dos pequenos, médios e grandes produtores. Segundo ele, o valor da mão de obra equivale a 50\% 
dos custos totais da produção de tomates. Para ele, como os pequenos utilizam a mão de obra da sua família, não tem esse custo e, por isso, teriam a "vantagem" de, mesmo em ano com preços mais baixos do tomate, poderem garantir uma renda satisfatória. Em relação ao uso da mão de obra assalariada e o seu custo para os capitalistas, Oliveira evidencia que:

Além disso, devemos ter claro que o produto final do processo de produção não é a mais-valia e sim a mercadoria. Esta contém a mais-valia, que não se confunde com o produto final do processo de produção, ou em outras palavras, a mais-valia está prisioneira à mercadoria e a sua realização se dá com a circulação, quando o movimento de rotação do capital se completa (D - M D). É no momento da produção que a mais-valia é gerada pelo trabalho (das classes trabalhadoras) ou seja, é produzida; porém é no momento da circulação que a mais-valia é realizada. (OLIVEIRA, 1981, p. 5-6)

Aqui, além da questão acima, também gostaríamos de remeter os leitores à discussão que fizemos no início do capítulo sobre a renda da terra como meio de produção fundamental na agricultura capitalista.

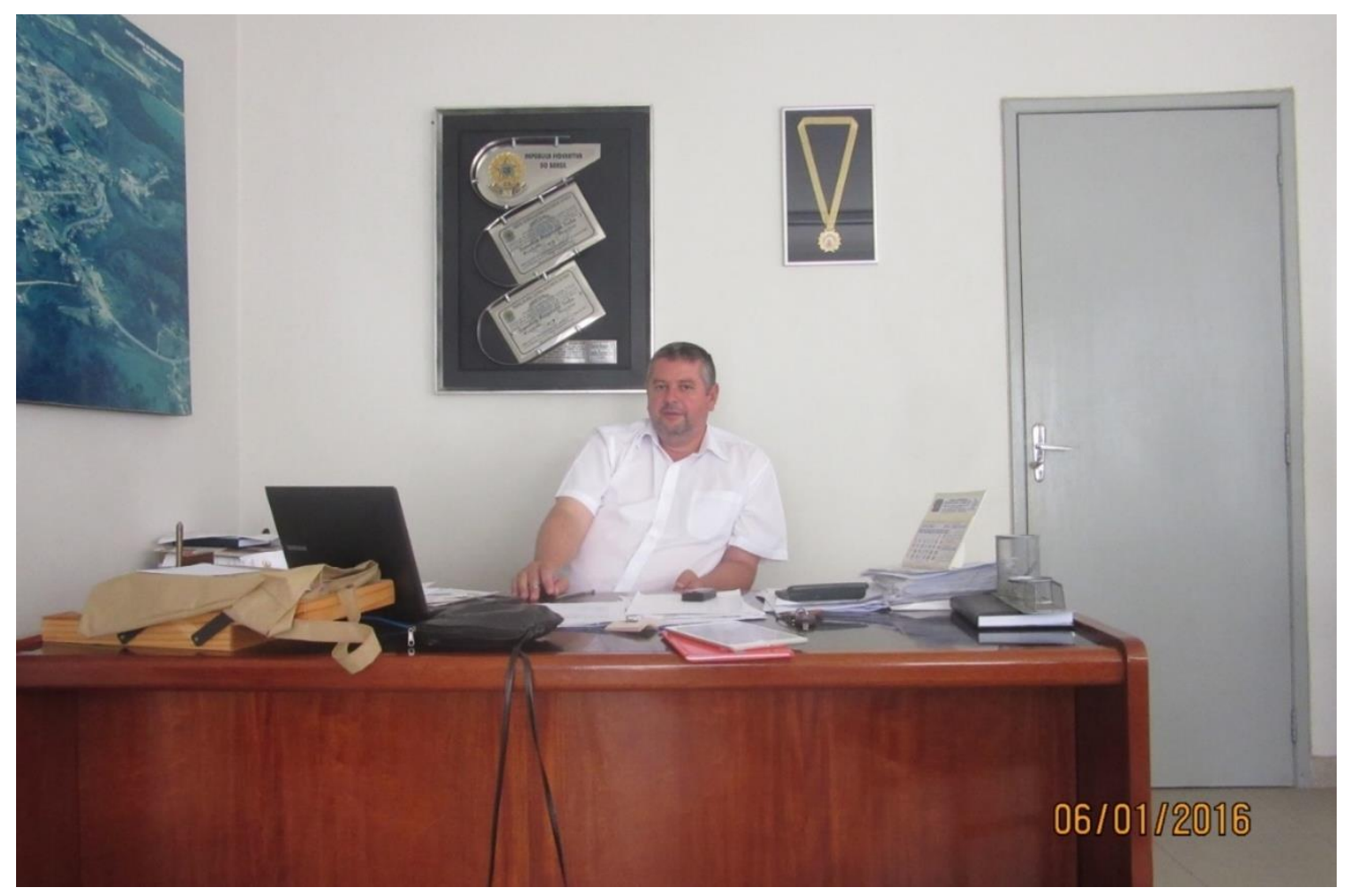

Foto 1: Gabinete do prefeito de Ribeirão Branco, Sandro Sala. Foto: Lucinei Paes de Lima, jan. 2016.

O nosso próximo entrevistado é um grande produtor de tomates. Tentamos por várias vezes o contato sem sucesso até que foi possível o nosso encontro, mas, como ficou evidente que não estava à vontade para nos conceder a entrevista, optamos por chamá-lo de "Produtor B" para evitarmos transtornos maiores. 
Lucinei: Quem são as pessoas que plantam tomates em Ribeirão Branco?

Produtor B: Olha, aqui em Ribeirão Branco todo mundo planta pelo menos um pouquinho de tomate, tem pequeno, médio e grande produtor.

Lucinei: Como podemos definir quem é pequeno, médio ou grande produtor de tomates?

Produtor B: Tem que pegar uma média. Para mim é médio produtor aquele que planta acima de 50 a 80 mil pés de tomate e grande é aquele que planta acima de 200 mil pés. Então, por isso, eu acho que juntando com os pequenos, eles plantam mais que nós até. Se você pegar o primeiro ciclo, a primeira safra do ano que é plantada no período de agosto a setembro, nesse período os pequenos é que mandam porque é a safra que fica mais barata, tem menos pragas nesse período.

Lucinei: Na sua opinião qual é a maior desvantagem dos pequenos produtores em relação aos grandes?

Produtor B: A diferença é na comercialização e na quantidade de mil pés plantada. Na comercialização, o nosso tomate vai pra onde nós quiser. Onde a gente quiser levar a gente leva, já os pequenos não.

Lucinei: Você e seu irmão são a empresa irmãos Oliveira. Por que vocês escolheram o tomate para investir?

Produtor B: Eu e meu irmão plantamos porque veio do meu pai, aprendemos isso ainda criança e veio assim de família.

$\mathrm{O}$ tomate é de quem quer arriscar mais para ganhar mais. $\mathrm{O}$ tomate rende muito dinheiro, mas se não der certo, quebra também. O que você ganhou em vinte anos pode perder tudo em três anos ou mesmo no primeiro ano que errar. Tem que ver o jeito de tomar conta da roça, não pode arriscar tudo o que você tem no tomate. Nós temos um pouco de gado, milho, feijão, isso ajuda equilibrar, mas não se compara ao lucro que dá o tomate, nada dá dinheiro igual tomate aqui. Se acertar bem, é o que mais dá dinheiro. Depois do tomate nós plantamos milho e às vezes feijão para aproveitar a terra pronta e também os insumos que foram aplicados nela.

Lucinei: Quantos mil pés de tomate vocês plantam e quantos funcionários vocês têm?

Produtor B: Plantamos neste ano 600 mil pés de tomate e, no momento, temos 120 famílias registradas.

Lucinei: Qual é o custo calculado da produção e quanto disso é utilizado para veneno e demais insumos?

Produtor B: Calculo o custo de 6 mil reais pra cada mil pés de tomate e, disso, a metade, 3 mil reais, fica nas lojas de insumos, a outra metade é gasta com mão de obra. A nossa produção varia de 350 a 400 caixas para cada mil pés de tomate, depende muito da saúde da roça. (Entrevista de 4 jan. 2016)

Considerando a quantidade declarada de pés plantados pelos irmãos Oliveira - 600 mil pés - e o valor do custo informado por ele - de 6 mil reais para cada mil pés de tomate -, chegamos a um investimento para o ano de 2016 de $\mathrm{R} \$ 3.600 .000,00$ (três milhões e seiscentos mil reais). Esses valores reforçaram o nosso entendimento sobre o que os entrevistados queriam dizer sobre a produção de tomates ser cara e de alto risco.

Não foi possível conversarmos com os proprietários das duas maiores empresas produtoras de tomates no município, Condor e Santa Bárbara. Mas, com o compromisso de não divulgarmos nomes, conversamos com alguns responsáveis pelas roças de tomates que nos deram os seguintes depoimentos: 
Lucinei: Quantos mil pés de tomate os irmãos Condor e Santa Bárbara produzem em Ribeirão Branco?

*: Só aqui em Ribeirão Branco, juntando as duas firmas, Condor e Santa Bárbara juntas plantaram 1.077.000 [um milhão e setenta e sete mil] pés no ano de 2016.

Lucinei: E você tem alguma estimativa da produção deles em outras regiões? *: Em Mogi Guaçu, plantou 470 mil pés nessa safra passada e, em Minas Gerais, esse ano a safra será de 1.990 .000 , quase 2 milhões de pés, porque lá em Minas não faz frio, então planta $o$ ano inteiro, diferente daqui.

Lucinei: Se juntarmos toda a produção chegaremos a um número aproximado de 4 milhões de pés de tomate plantados nessa safra?

*: Isso, mais ou menos. Só em Ribeirão Branco ele planta cinquenta alqueires de terra em tomate, que para o plantio de tomate é considerado muito!

Lucinei: Essa empresa tem muitos empregados?

**: Só em Ribeirão Branco tem uma média de 220 pessoas, aproximadamente, registradas. A conta é a seguinte: uma pessoa cuida de até 5 mil pés de tomate. Aí, dependendo da quantidade de pés que eles querem plantar, é feito esse cálculo.

Lucinei: São as mesmas pessoas que trabalham nas fazendas de Ribeirão Branco, Mogi Guaçu e Minas Gerais?

**: Pra Minas vão tudo daqui de Ribeirão e ficam lá morando porque aqui tem mão de obra especializada, todo mundo aqui sabe plantar tomate e já conhecem o jeito do trabalho, então vão todos daqui mesmo. Agora, para Mogi é o seguinte, o pessoal que planta no verão aqui em Ribeirão Branco, no inverno, algumas dessas famílias vão plantar em Mogi e depois voltam a plantar aqui no verão novamente. Não são pessoas, são famílias que se mudam de um lugar para o outro.

Lucinei: Então, diferente de Mogi que são os trabalhadores de Ribeirão Branco que migram para lá durante a safra e depois voltam, em Minas, ficam residindo lá, certo?

**: Sim.

Lucinei: Agora, sobre a qualidade do tomate, é diferente de um lugar para o outro?

*: Sim, dizem que o tomate produzido em Ribeirão Branco tem maior qualidade. A diferença é na quantidade de terra que é utilizada para produzir: aqui em Ribeirão Branco se usa mais terra porque é muito morro aqui e em outros lugares é plano. A diferença pras outras regiões é de até 2 ha pra cada 300 mil pés de tomate. Enquanto nas outras regiões se coloca 31 mil pés por alqueire, aqui em Ribeirão se coloca cerca de 27 mil pés por alqueire, no máximo. Mas ainda assim o tomate daqui é o melhor do que o de Minas e Mogi Guaçu. Isso compensa!

Lucinei: O tomate produzido por essas empresas também vai para a indústria? *: Do tomate que eles produzem, nada vai pra indústria, é tudo para salada, tomate firme, resistente, que aguenta inclusive ser passado na máquina de classificação. (Entrevista, jan. 2016)

Esses depoimentos, considerando os valores apresentados, nos ajudam a compreender a

lógica do movimento de circulação capitalista como explicada por Marx:

... na circulação $D-M-D$... ambos os extremos têm a mesma forma econômica. Ambos são dinheiro, não sendo, portanto, valores-de-uso qualitativamente distintos, pois o dinheiro é precisamente, a figura metamorfoseada das mercadorias, nas quais se encontram extintos seus valores-de-uso particulares. Primeiro trocar 100 libras esterlinas por algodão e, então, trocar novamente o 
mesmo algodão por 100 libras esterlinas, ou seja, dando uma volta, trocando dinheiro por dinheiro, o mesmo pelo mesmo, parece ser uma operação tão carente de objetivos como absurda. Uma soma de dinheiro unicamente podese distinguir de outra pela sua magnitude. Por conseguinte, o processo $D-M$ $D$ não deve seu conteúdo a nenhuma diferença qualitativa entre seus extremos, pois ambos são dinheiro, mas isto sim, somente a sua diferença quantitativa. No final, subtrai-se da circulação mais dinheiro, do que aquele que no início se aplicou nela. $\mathrm{O}$ algodão comprado por 100 libras esterlinas é, por exemplo, revendido a $100+10$ libras esterlinas, ou seja, 110 libras esterlinas. A forma completa desse processo é, portanto, $D-M-D$ em que $D^{\prime}=$ $D+>D$, isto é, igual à soma do dinheiro adiantada inicialmente mais um incremento. Esse incremento, ou o excedente acima do valor originalmente adiantado, denomino-o de mais-valia (surplus value). O valor adiantado, originalmente não só, pois, se conserva na circulação, mas também nela modifica sua magnitude de valor, adiciona mais-valia, ou seja, valoriza-se. E esse movimento transforma-o em capital. (Marx, 1984, p. 183-1847 apud OLIVEIRA, 1991, p. 54-55 - grifos no original)

É apropriado informar que na data dessa entrevista, 8 de janeiro, nos disseram que as empresas Condor e Santa Bárbara enviaram uma produção de 8,505 mil caixas de tomates, e a produção do final de semana anterior à entrevista (de 1 a 3 de janeiro) havia sido de 20 mil caixas de tomates encaminhadas ao Ceasa de São Paulo. Sobre a soma do total de investimentos dessas empresas, considerando o depoimento de nosso interlocutor, que informou uma produção de 4 milhões de pés de tomate durante o ano de 2016 - entre Ribeirão Branco, Mogi Guaçu e Minas Gerais -, significaria um total de 24 milhões de reais de investimentos. Desses, mais de 6 milhões só em Ribeirão Branco.

O Sr. Neri Ubaldo é outro produtor de tomate com quem conversamos. Ele nos disse que já chegou a investir praticamente tudo o que tinha na plantação de tomate, mas que também já perdeu quase todos os seus bens para pagar dívidas. Segundo ele, o preço tinha sido tão ruim que não foi suficiente para pagar nem mesmo as despesas com mão de obra e insumos.

Já em 2016, o Sr. Neri plantou 140 mil pés de tomate e, como teve que decretar falência e as suas terras haviam sido penhoradas no banco durante o episódio citado, agora paga arrendamento para produzir. O Sr. Neri nos falou sobre suas dificuldades:

Neri Ubaldo: Aqui em Ribeirão o problema é a parte de financiamento, sem financiamento não tem jeito de plantar tomate, está ficando muito caro.

Esse ano, com a alta do dólar, as lojas de venenos e sementes tão dizendo que o movimento caiu em $30 \%$. E os lojistas não estão querendo vender fiado por causa do preço das coisas mesmo e isso tá dificultando tudo para nós.

Como eu já quebrei uma vez, a gente planta com cuidado agora porque é muito difícil perder tudo o que a gente conquistou.

Lucinei: Como é feita a comercialização da sua produção?

Neri Ubaldo: Aqui funciona assim: aqueles que não conseguem plantar por conta própria e não pegam financiamento no banco acabam pegando um tipo

\footnotetext{
${ }^{7}$ MARX, K. El Capital, tomo I, vol. I. 14. ed., México: Siglo Veintiuno, 1984.
} 
de financiamento com as grandes empresas que plantam tomate por aqui. Então pega o dinheiro deles e vende a produção para eles, porque essas empresas também são donos de barracas no Ceasa.

Lucinei: A maioria das terras do município e utilizada para o plantio de tomates?

Neri Ubaldo: Não, o tomate não precisa de muita terra para plantar, então as terras estão sendo ocupadas também cada vez mais pelas empresas de celulose, como o grupo Orsa. Porque o povo ficou muito endividado no banco com o tomate e aqueles que não tinham o que fazer ofereceram as suas terras para plantar pinos e eucalipto para vender para essa empresa no grupo Orsa [que atua no mercado de papel e celulose]. Tem muita terra que era produção diversificada que virou tudo eucalipto e pinos hoje.

Lucinei: Você disse que está pagando arrendamento para plantar. Quanto custa? E qual é o preço da terra hoje?

Neri Ubaldo: Eu pago de 2 mil a 2,5 mil por alqueire, é bem caro! Agora, terra pra comprar aqui em Ribeirão é mais barato que nas redondezas, mas, ainda assim, custa de 30 a 40 mil reais o alqueire, dependendo da localização dela. Mas olhe, se você olhar ao redor, como em Itapeva, aí você já vai pagar cerca de 70 a 80 mil reais o alqueire, viu! Aqui em Ribeirão é mais barato porque tem muito morro e muito mato, e hoje não pode mexer mais, então desvaloriza um pouco, né? A vantagem das terras mais planas é que aí dá pra plantar tudo com maquinário, diferente daqui, que tem que ser mais braçal mesmo. (Entrevista com Neri Ubaldo, vereador e médio produtor de tomate, 5 jan. 2016)

O Sr. Neri fala sobre os valores da terra e a diferença de valores entre Ribeirão Branco e os municípios vizinhos. A terra em Ribeirão Branco é mais barata por não ser propícia para o uso de mecanização, o que acreditamos ser uma das hipóteses para o número expressivo de estabelecimentos rurais de camponeses no município.

O depoimento do Sr. Neri exemplifica o fato de que apostar tudo na monocultura do tomate na expectativa de obter lucro pode gerar falência. Vale dizer que os camponeses, mesmo os que plantam tomates, ao diversificarem a sua produção, ainda que num momento de preços baixos, conseguem se recriar, como veremos adiante.

Abaixo, alguns registros das fazendas produtoras de tomates em Ribeirão Branco. 


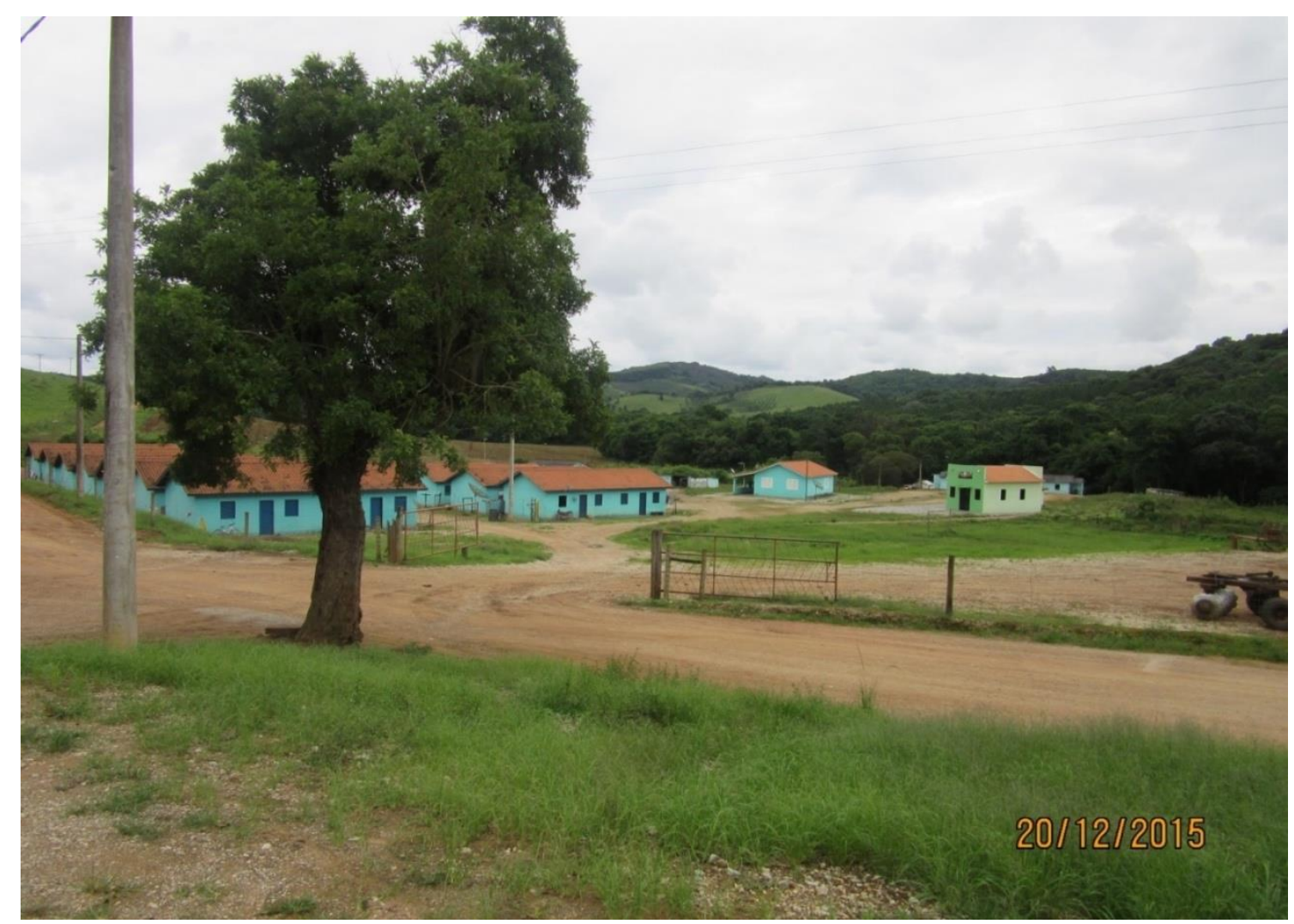

Foto 2: Fazenda do grupo Condor (315 mil pés de tomate). No detalhe, o alojamento onde os assalariados residem durante a safra. Bairro Coimbra. Foto: Lucinei Paes de Lima, dez. 2015.

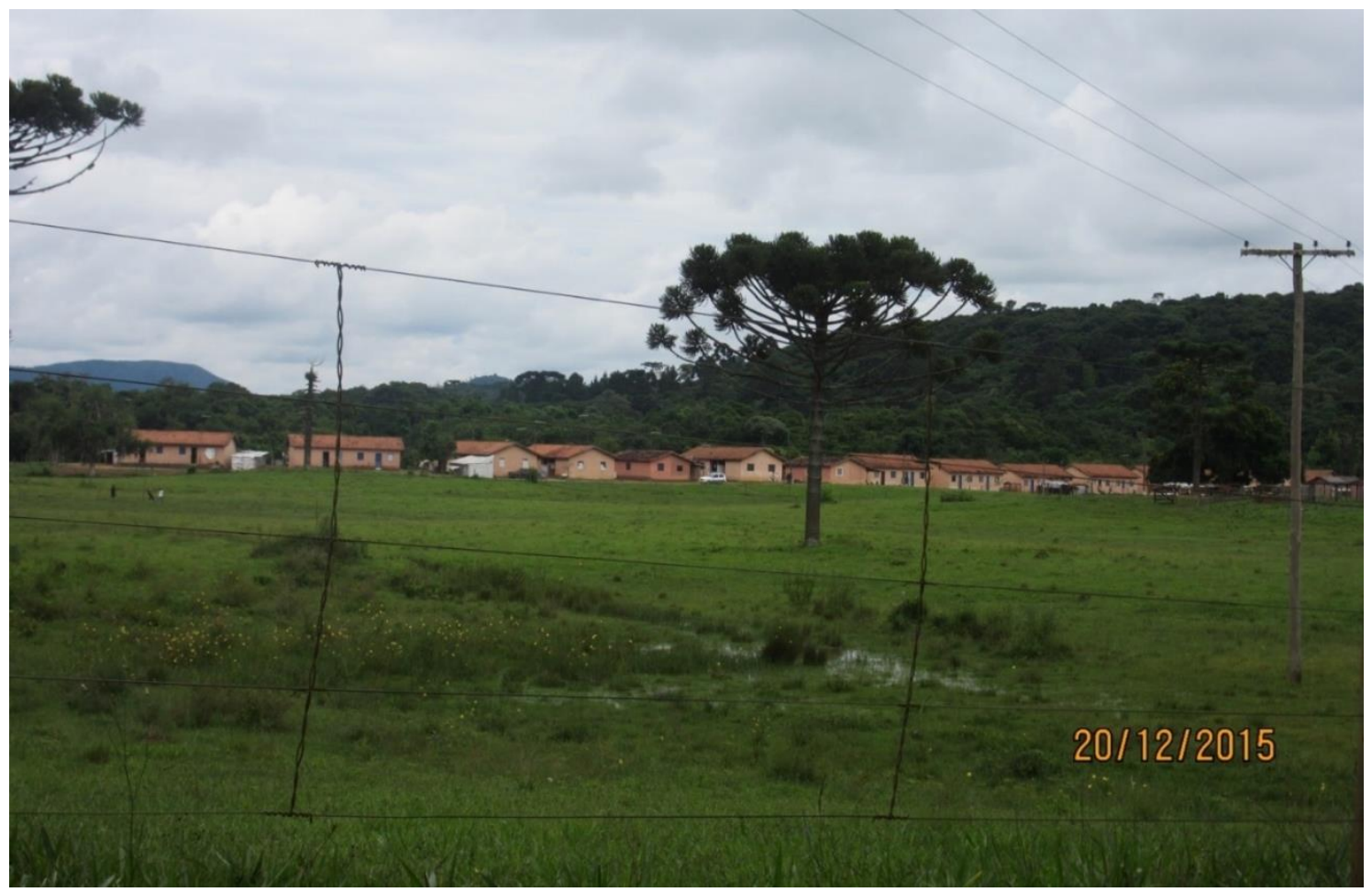

Foto 3: Alojamento da Fazenda Santa Rosa, parceira do grupo Santa Bárbara e Condor, bairro do Rio Apiaí. Foto: Lucinei Paes de Lima, dez. 2015. 


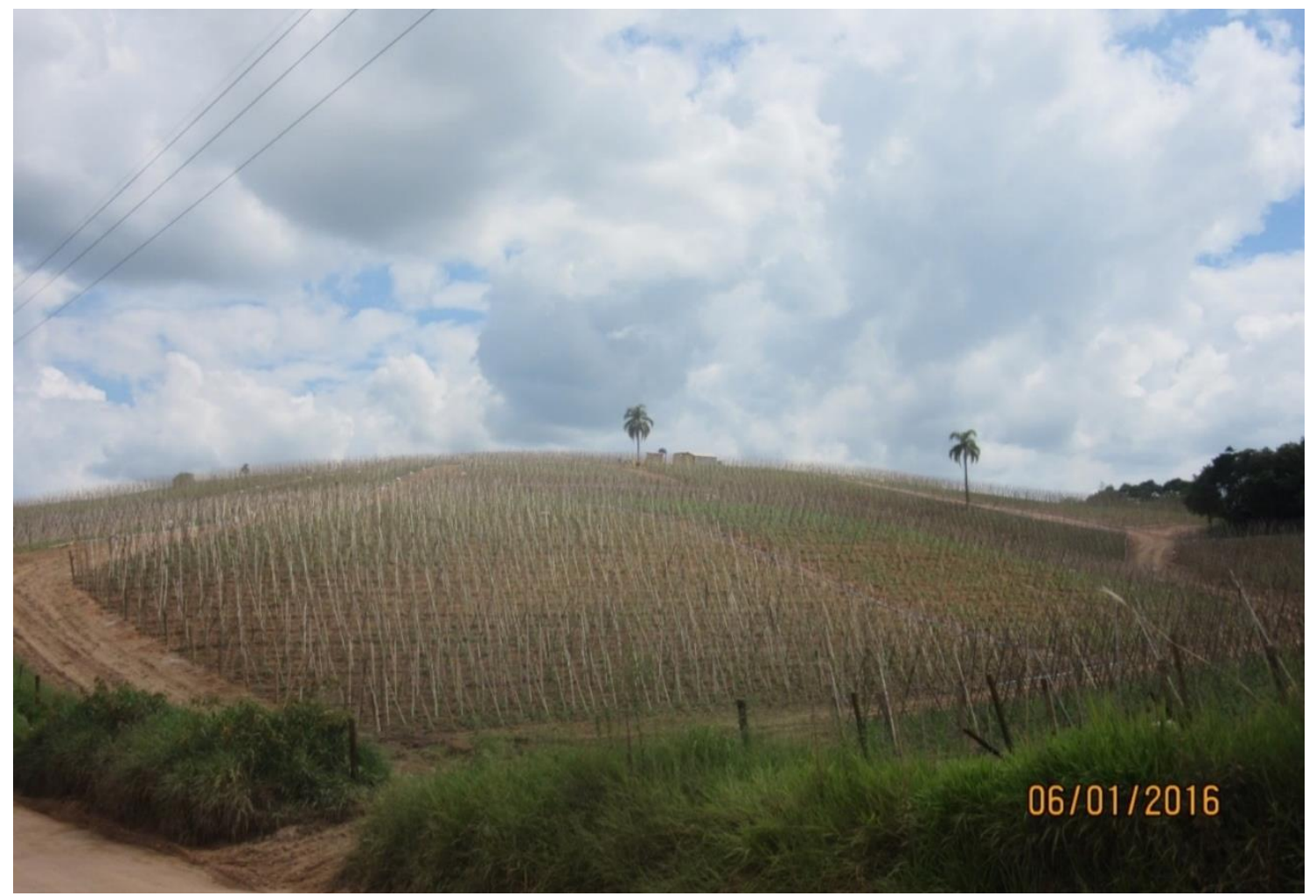

Foto 4: Plantação de tomates da empresa Condor em terras arrendadas. São 285 mil pés, bairro Cai-Cai. Foto: Lucinei Paes de Lima, jan. 2016.

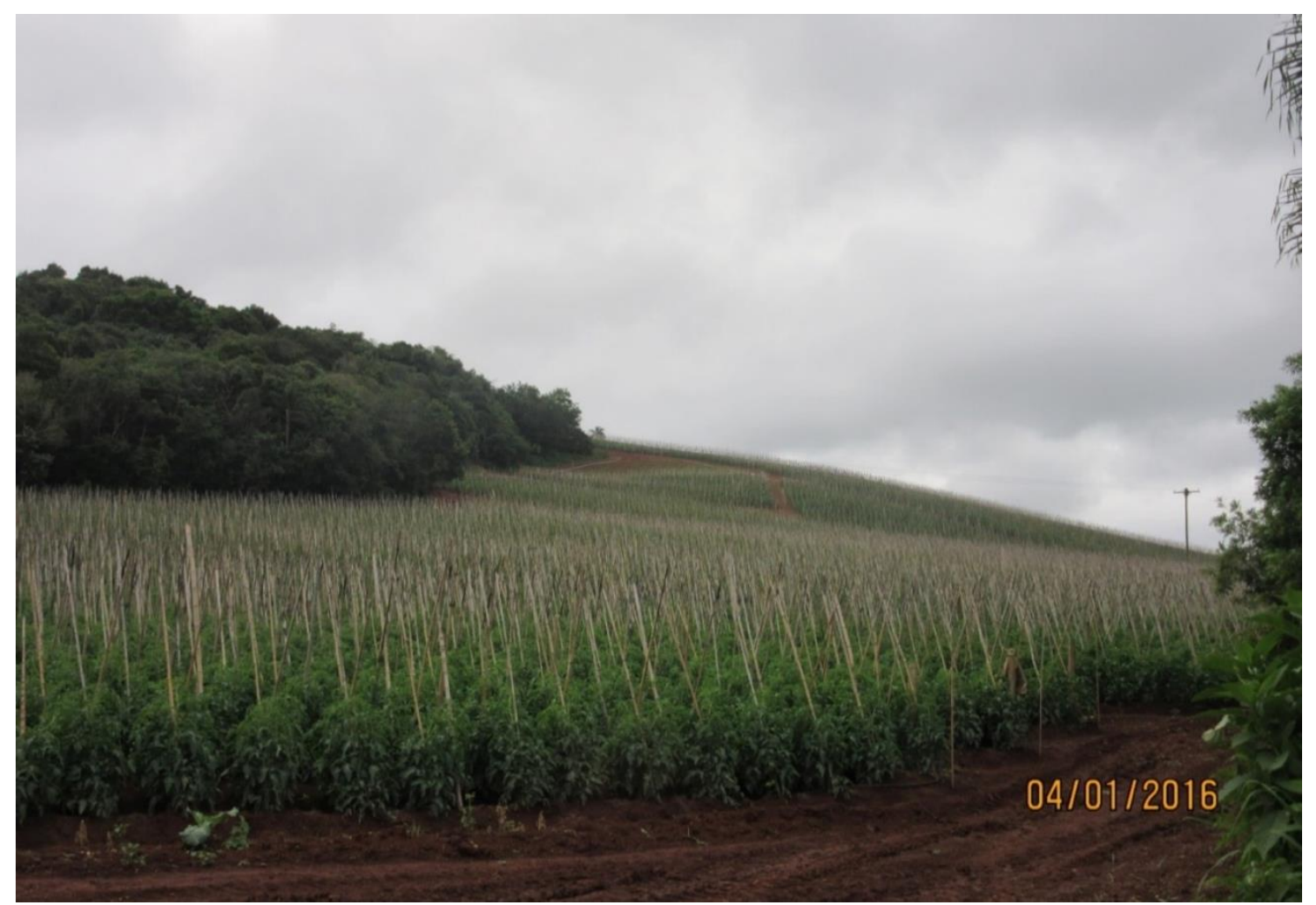

Foto 5: Plantação de tomates da empresa Condor. Fazenda Fiuza, 265 mil pés de tomate, bairro do Rio Apiaí. Foto: Lucinei Paes de Lima, jan. 2016. 
Nas imagens abaixo, algumas das placas comunicando o uso de agrotóxicos nas fazendas de tomate. À esquerda, a proibição da entrada das pessoas junto da orientação para o banho daqueles que aplicaram os venenos. À direita, outra placa proíbe a entrada de menores de dezoito anos no local, devido à lei que proíbe o trabalho de menores de idade.
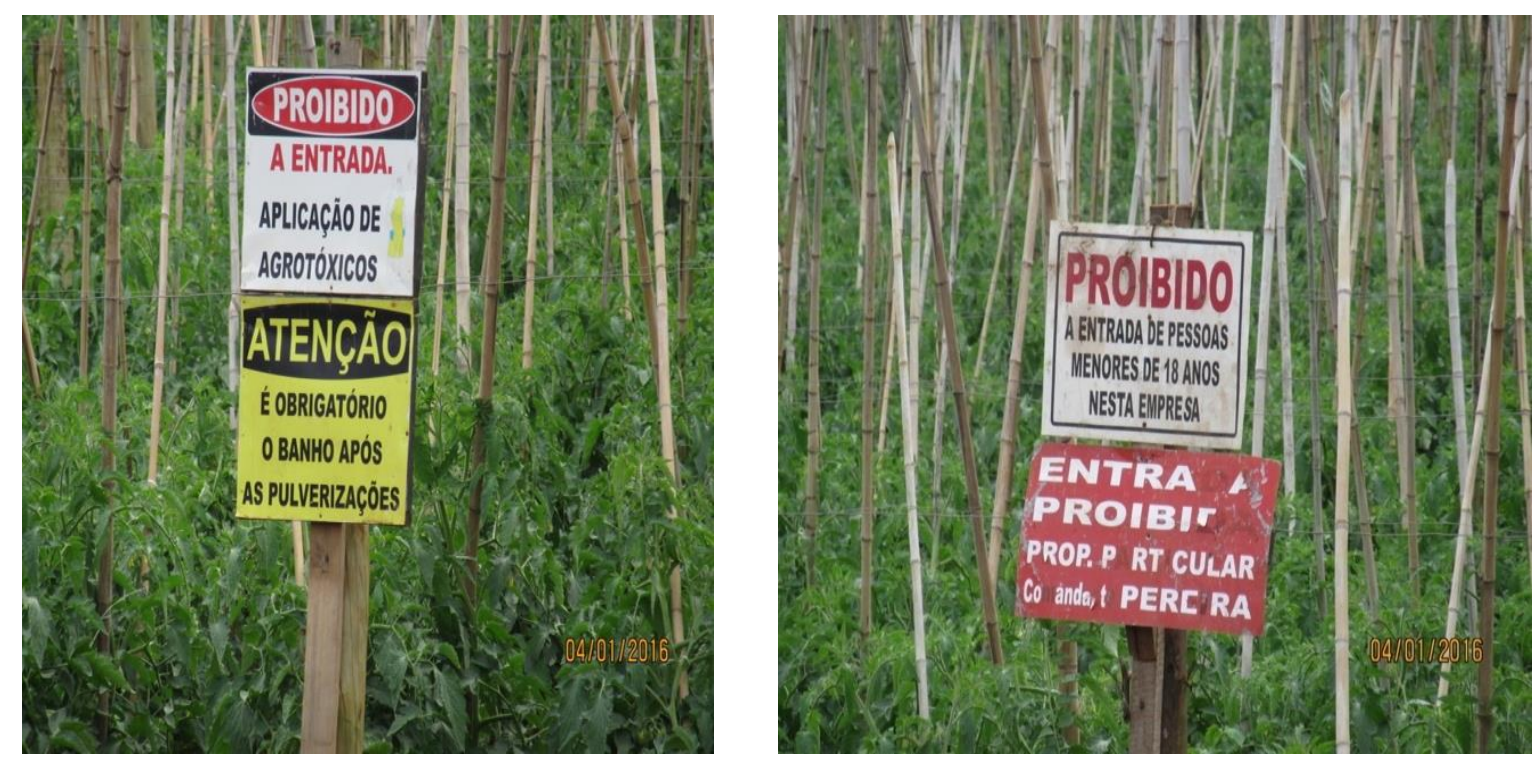

Fotos 6 e 7: Placas alertam para o perigo dos agrotóxicos utilizados nas plantações de tomate. Fazenda Fiuza (plantação da empresa Condor), bairro do Rio Apiaí. Foto: Lucinei Paes de Lima, jan. 2016.

Sobre o uso de agrotóxicos e o seu impacto na saúde dos moradores do município, procuramos o ex-secretário municipal de saúde, Sr. Caster César, que concordou em falar conosco e nos relatou a seguinte situação:

Se você olhar para o número de casos de câncer no município e verificar a proporcionalidade em número de habitantes, vai ver um número assustador. Não dá para afirmar $100 \%$ que é por conta da quantidade de veneno que utilizam para produzir tomates, mas que tem alguma relação, ah, isso eu acredito muito que sim! Além disso, existem vários casos de contaminação, muitas vezes as pessoas passam mal e nem sabem de onde vem, e ocorre é que foram envenenadas. (Entrevista com Caster César, jul. 2015) ${ }^{8}$

Segundo o secretário, o uso de veneno é mais intensivo nas plantações dos capitalistas. Muito embora os médios e mesmo os pequenos produtores também façam amplo uso de agrotóxicos em suas plantações, os grandes produtores, no intuito de garantir maior produtividade, combater as pragas e ter mais lucros, aumentam o número de aplicações desses produtos químicos e ampliam os riscos para a saúde.

\footnotetext{
${ }^{8}$ Caster César é um defensor da agroecologia e trabalhou como secretário municipal de saúde de 2009 a 2012. Também é professor de filosofia na rede estadual de ensino.
} 
Também ouvimos o diretor do Sindicato de Empregados Rurais de Ribeirão Branco e Guapiara, Sr. José Vicente, que nos informou que, embora as placas instaladas nas roças orientem manter distância das plantações e proíbam a entrada de menores de dezoito anos, essa regra não é cumprida por todas as fazendas de tomates.

Em visita ao sindicato de trabalhadores rurais, também buscamos entender as relações de trabalho dos assalariados nas fazendas de tomate de Ribeirão Branco. O Sr. José Vicente nos relatou a seguinte situação:

Aqui em Ribeirão Branco, os grandes produtores de tomates se articulam entre si. Eles não investem só no tomate, eles também compram novas fazendas, imóveis, são donos de transportadoras de produtos para os Ceasas e donos de boxes de vendas em vários Ceasas. Também têm bois, plantam soja fora daqui, ou seja, eles diversificaram e, com isso, nunca perdem dinheiro com o tomate. Mas o tomate virou uma marca registrada deles. Para você ter uma ideia, para alguém se envolver no mundo dos negócios do tomate é preciso a permissão deles. Por exemplo, se você compra um caminhão e quer começar a ganhar a vida fazendo frete, levando a produção para São Paulo, você não consegue! Porque é um grupo fechado que coordena isso aqui! Só pode fazer o transporte, só pode fazer o frete quem eles deixam! Então essa marca que virou o tomate é coisa séria. É só você observar no comércio local, no banco, na missa; usar uma camisa ou boné com o logotipo de plantador de tomate é sinônimo de poder. Não é à toa que eles exibem adesivos denominados "máfia do tomate". Isso está nas camisas, nos para-choques de caminhões, nas suas caminhonetes e até nos carros de passeio. (Entrevista com José Vicente, jan. 2016)

Para compreendermos as relações de trabalho nas fazendas de tomate, perguntamos ao

Sr. José Vicente sobre como seria o contrato de trabalho dos assalariados:

Lucinei: Como é feita a negociação sobre os rendimentos das roças sabendo que, como informado anteriormente, cada pessoa é responsável por cultivar e produzir 5 mil pés de tomate? Eles são registrados em carteira? Tem participação nos lucros?

José Vicente: Temos o acordo coletivo, onde os dois sindicatos (patronal e de trabalhadores) se reúnem na data base que é em outubro. Então, em setembro, a gente faz a reunião com trabalhadores, aí discute a pauta, o salário, a PLR [participação nos lucros ou resultados, que é o valor de cada caixa produzida que fica com o trabalhador] e outras condições de trabalho: banheiros nas roças, água limpa, local para fazer as refeições. Depois disso, elabora a pauta da convenção coletiva que é registrada no Ministério do Trabalho e, depois, mandam convocação para a reunião. Aí fecha a pauta e protocola. No dia da reunião, tem intimação e os sindicatos discutem, e cada um apresenta a sua proposta.

Ano passado foi definido o valor de 1,70 reais a PLR [ou seja, por cada caixa de tomate produzida, o trabalhador recebia esse valor] e esse ano pagaram 2 reais a caixa. Os trabalhadores pediram 3 reais, mas não conseguimos chegar nisso. O piso da categoria é de 1,2 mil reais, mas também não conseguimos fazer chegar nesse valor, isso por conta dos demais sindicatos pelegos do restante da região que negociam abaixo disso, mas o nosso acordo é sempre o maior que o desses sindicatos! Então o piso neste ano ficou em 941,20 reais. 
Mas agora tem um processo rolando de que o piso, a partir do ano que vem, deverá acompanhar o piso estadual, que deve ser uns mil reais. Então vamos ver para o próximo acordo se conseguimos avançar.

Lucinei: Então os trabalhadores são registrados em carteira no valor desse piso e, ao final da lavoura, recebem um valor a mais referente à quantidade de caixas produzidas?

José Vicente: Sim, cada pessoa da família que cuida de 5 mil pés de tomate é registrada em carteira e, ao final, recebe um valor por cada caixa produzida pela sua roça. Quanto mais ele consegue produzir, mais ele vai receber. É aí que todo mundo trabalha como um louco para cuidar da sua roça. Veja bem, a roça não é dele, é do fazendeiro, mas ele cuida como se fosse dele entende? (Idem)

O Sr. José Vicente nos forneceu uma cópia do acordo coletivo de trabalho do ano de 2016 para melhor compreensão da negociação estabelecida entre a entidade que representa os trabalhadores - Sindicato de Empregados Rurais de Ribeirão Branco e Guapiara - e a entidade que representa o setor patronal - Sindicato Rural de Ribeirão Branco (Figura 12 e Figura 13).

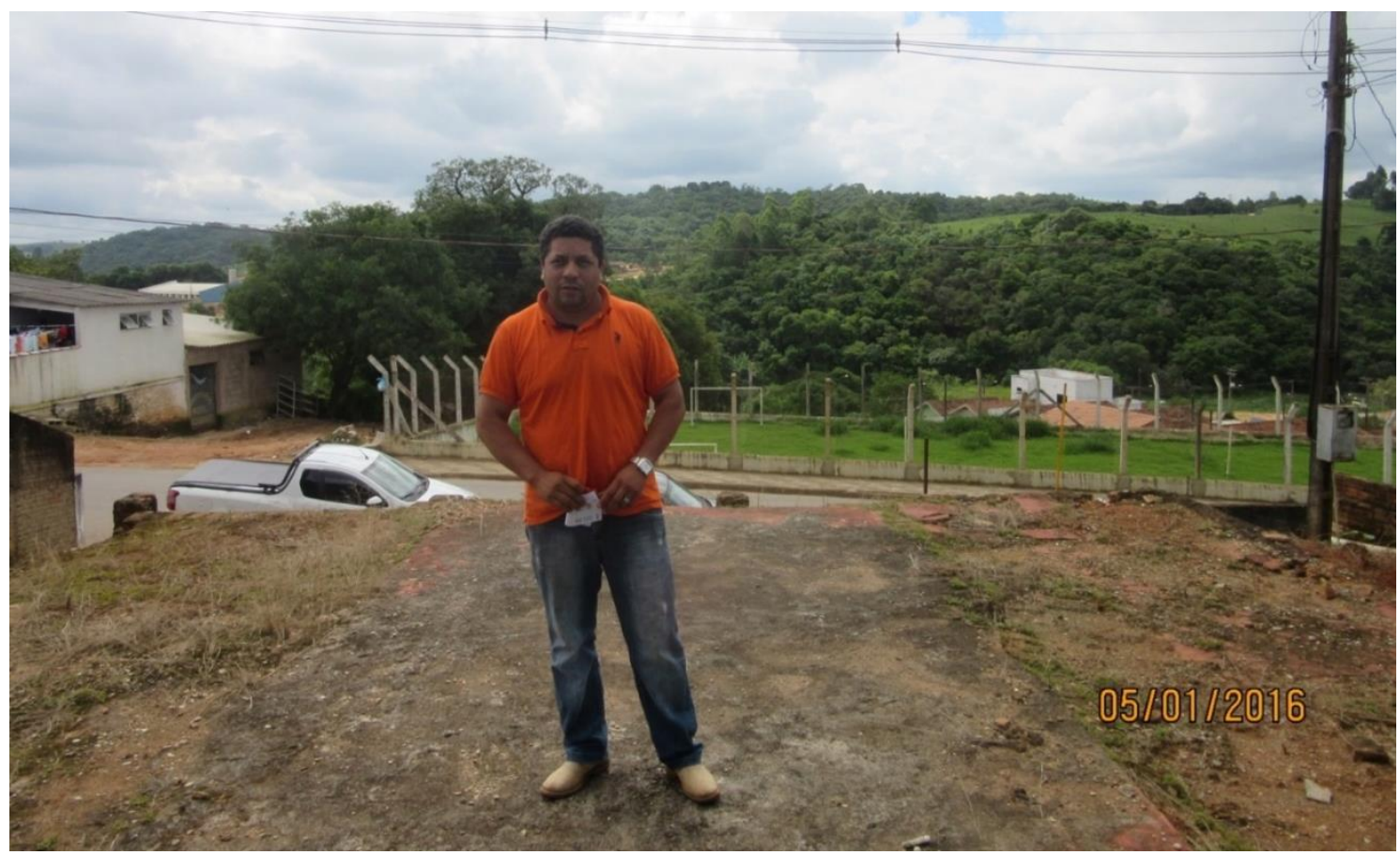

Foto 8: José Vicente, diretor do Sindicato de Empregados Rurais de Ribeirão Branco, na sede do sindicato. Foto: Lucinei Paes de Lima, jan. 2016. 


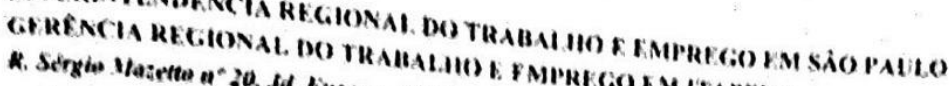

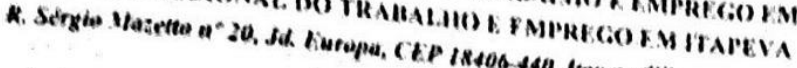

\title{
ATA DE REUNIÄO MEDIACĂO IIMESA REDONDA
}

\author{
Processo n': 46427.003226/2015.47
}

Aos vinte e sete dias do mess de novembro do ano de dois mil e quinze, as ltapeva, Rue compareceram à Gerência Regıonal do Trabalho e Emprego em de Mesa Redonda Mazetto, $n^{\circ} 20$. Jardim Europa, Ilapeva/SP. para participar Ferreira de unda sob a mediaçáo do Gerente Regıonal, Lisandro de Almeida DE RIBEIRÁO lado. O suscitante. SINDICATO DOS EMPREGADOS RURAIS to lado o suscitado pelo $\mathrm{Sr}$. Claudinei Felizardo da Silva - Presidente. e de outro RIBERAOItado, representando a categoria patronal. SINDICATO RURAL DE RIBEIRAOO BRANCO. CNPJ 04.369.649/0001-35, representado pelo Sr Joel de Souza Meira. Presidente, que estava acompanhado do advogado Diego Rodrigues Zanzarini Após breve introduçào ferta pelo mediador, relembrando pnncipıos norteadores das negociaçóes coletivas em geral e do procedımento de mediaçao. seguiram-se debates sobre as propostas constantes na Pauta de Reivindicaçoes apresentadas pela suscitante. contra-propostas apresentadas pelo representante da entidade suscitada e sugestóes do mediador. tendo as partes acordado quanto ao seguinte: A) Manutençâo da data base em 01/10. definindo-se, portanto. a vigéncia da CCT 2015/2016 de 01/10/2015 a 30/09/2016: B) Manutençăo para o periodo de 01/10/2015 a 31/12/2015 do piso salarial em valor correspondente ao Saláno Minumo Estadual acrescido de $4 \%$ (RS 941,00). C) Adoçăo para o periodo de 01/01/2016 a 30/09/2016. como Piso Satarial da Categoria, do Sałário Minimo Estadual ("Piso Estadual), em sua faixa inicial. sendo que para os empregados que atualmente têm salario mensal superior aos RS 941.00 , do mesmo indice referente ao aumento que ccorrera a partir de janeuro de 2016 em relaçà aos tais RS 941,00 D) A título. de Panticipacaro nos Lucros e Resultados fica definido para a cultura do tomate. - valor minumo de RS 2.00 por caixa produzida (reajuste de $18 \%$ em relação ao. valor atuat) e para culturas diversas 0 valor mirtmo de RS 1.60 por caixa freajuste de $23 \%$ em relaçào as act atuat com absoluta transparéncia e

Figura 12: Ata de reunião entre o Sindicato de Empregados Rurais de Ribeirão Branco e Guapiara e o Sindicato Rural de Ribeirão Branco. 


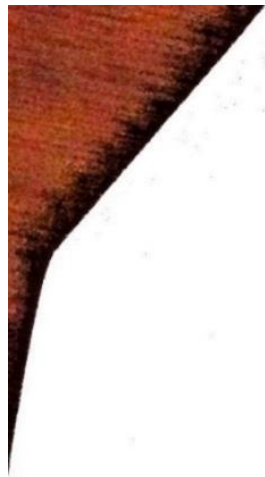

STPFRINTFNDENCIA RFS

CFRANCTA REGIONC IA REGIONAI. DO

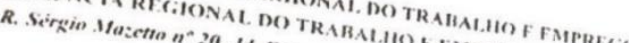

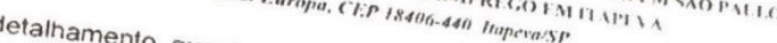

Pagamento dos quanto aos valores pagos a esse

Termos de Rescisão. manutenção do teor das dem Fica expressamente Pagamento de Salários de de Mediaçăo ocorridas demaıs cláusulas geraıs constgnada a integra Reuniâo de Mediafa em 03/11/2014 e que haviamencionadas Ata da Reuniao debatido entre os pcoro ocorida em 05/11/2013. Sido detalhadas na Ata da presente Ata de participantes. Eu, Lisandro de Almeida for alegado ou que vai rubricada 2 páginas, impressa em uma Almeida Ferreira, lavrei a que vai rubricada e assinada por mim e pelas única foltha, frente e verso, e

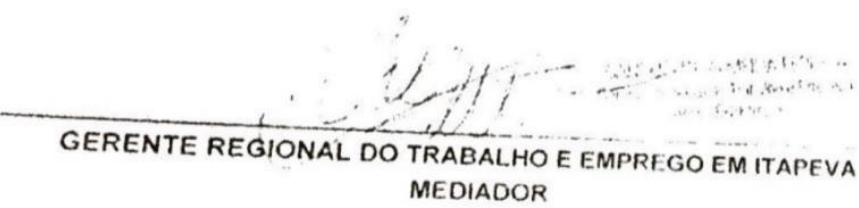
MEDIADOR

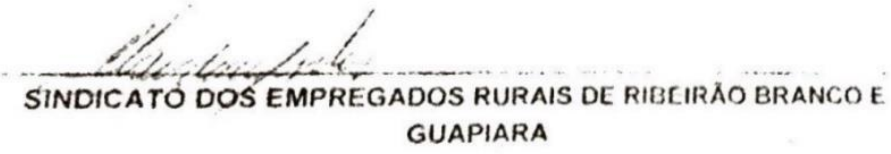
GUAPIARA

Figura 13: Ata de reunião entre o Sindicato de Empregados Rurais de Ribeirão Branco e Guapiara e o Sindicato Rural de Ribeirão Branco (cont.).

O Sr. José Vicente afirmou que a produção capitalista de tomates é o ramo de atividade que mais emprega mão de obra do município e, não por acaso, é a maior causa de conflitos entre patrões e empregados. Segundo o nosso interlocutor, o trabalho nas lavouras de tomate é extremamente exaustivo. Ele conta que, durante a lavoura, os trabalhadores não conseguem participar das atividades das comunidades de origem, não têm momentos de lazer e muito menos tempo para se dedicar às reuniões da categoria.

Situação diferente da dos camponeses que, mesmo diante do trabalho intenso, ainda que em menor ritmo nesse período, não deixam de se dedicar às atividades da sua comunidade. $\mathrm{O}$ campesinato não abre mão de vivenciar a vida de bairro. 


\section{A produção camponesa em Ribeirão Branco: produção de tomate e diversificação da produção}

O capítulo anterior tratou da produção capitalista de tomates. Agora iremos discutir como os camponeses de Ribeirão Branco produzem tomate.

O engenheiro agrônomo, Nicolau Theobaldo Werneck, da secretaria de agricultura do município, nos apresentou a seguinte situação. Segundo ele, existem cerca de 3 mil pequenos produtores no município e $80 \%$ deles plantam pelo menos um pouquinho de tomate por ano, além das outras culturas.

De acordo com os relatos dos camponeses, a maioria deles produz tomate uma vez no ano e escolhe plantar em um de dois períodos. O primeiro período, ou safra, é chamado de "roça do cedo", plantada a partir do mês de agosto com a colheita se encerrando em dezembro. O outro é chamado "roça da tarde", plantada em novembro-dezembro e colhida, no máximo, até maio, com a chegada do inverno. Segundo esses relatos, enquanto a primeira safra dura cerca de seis meses de trabalho, a última dura cinco meses, aproximadamente. A principal diferença entre elas está no fato de, no "plantio da tarde", a planta crescer mais rápido e ser mais suscetível a pragas, dessa forma, a produção tende a ser menor. Além disso, o controle de pragas aumenta os custos e, por isso, grande parte dos pequenos produtores escolhem plantar no primeiro período.

Acompanhamos um dia de plantação de tomates dos camponeses no bairro Coimbra. Cinco famílias decidiram plantar no mesmo período e, como são moradores da Associação dos Produtores da Microbacia do Rio Apiaí Guaçu (Banco da Terra) - que discutiremos no próximo capítulo -, plantaram lado a lado. Assim, mesmo que cada um tenha a sua própria roça e cuide dela individualmente, o dia do plantio é um dia de trabalho coletivo.

O dia da plantação é um dia feliz, quando os camponeses depositam na terra a esperança de fazerem boas colheitas. A família toda participa do trabalho, mesmo as crianças que, por um momento, parecem se divertir com a competição que criaram: ganhava quem plantasse mais em menos tempo.

Quando acabaram o plantio, as famílias se reuniram para um café coletivo - uma comemoração pelo fim da tarefa realizada. A Sra. Lucimara Barros preparou bolinhos de chuva para o café, além de pão com mortadela e até cerveja para os adultos (Foto 11 e Foto 12). 


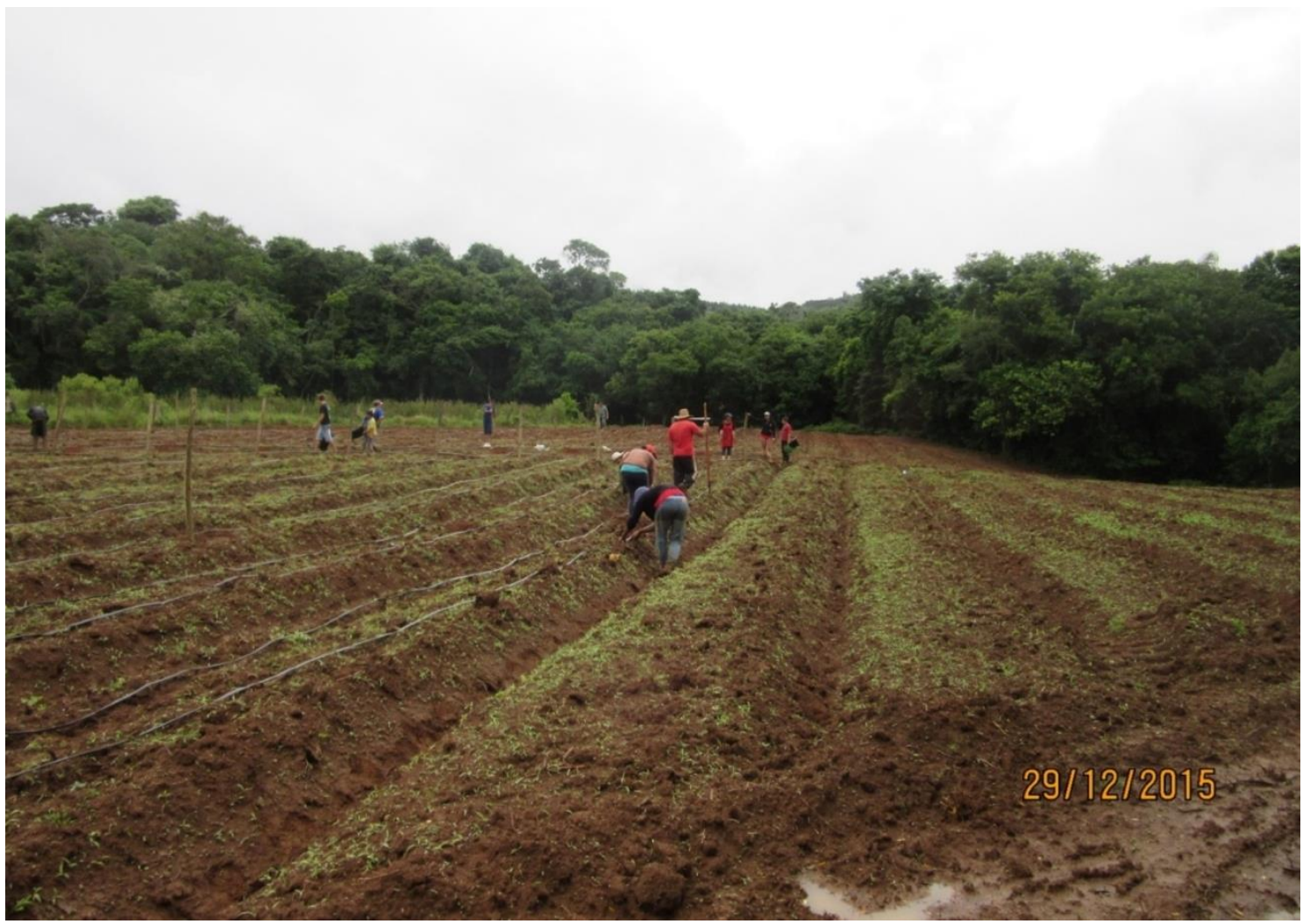

Foto 9: Camponeses plantando tomates, Associação dos Produtores da Microbacia do Rio Apiaí Guaçu - Banco da Terra, bairro Coimbra. Foto: Lucinei Paes de Lima, dez. 2015.

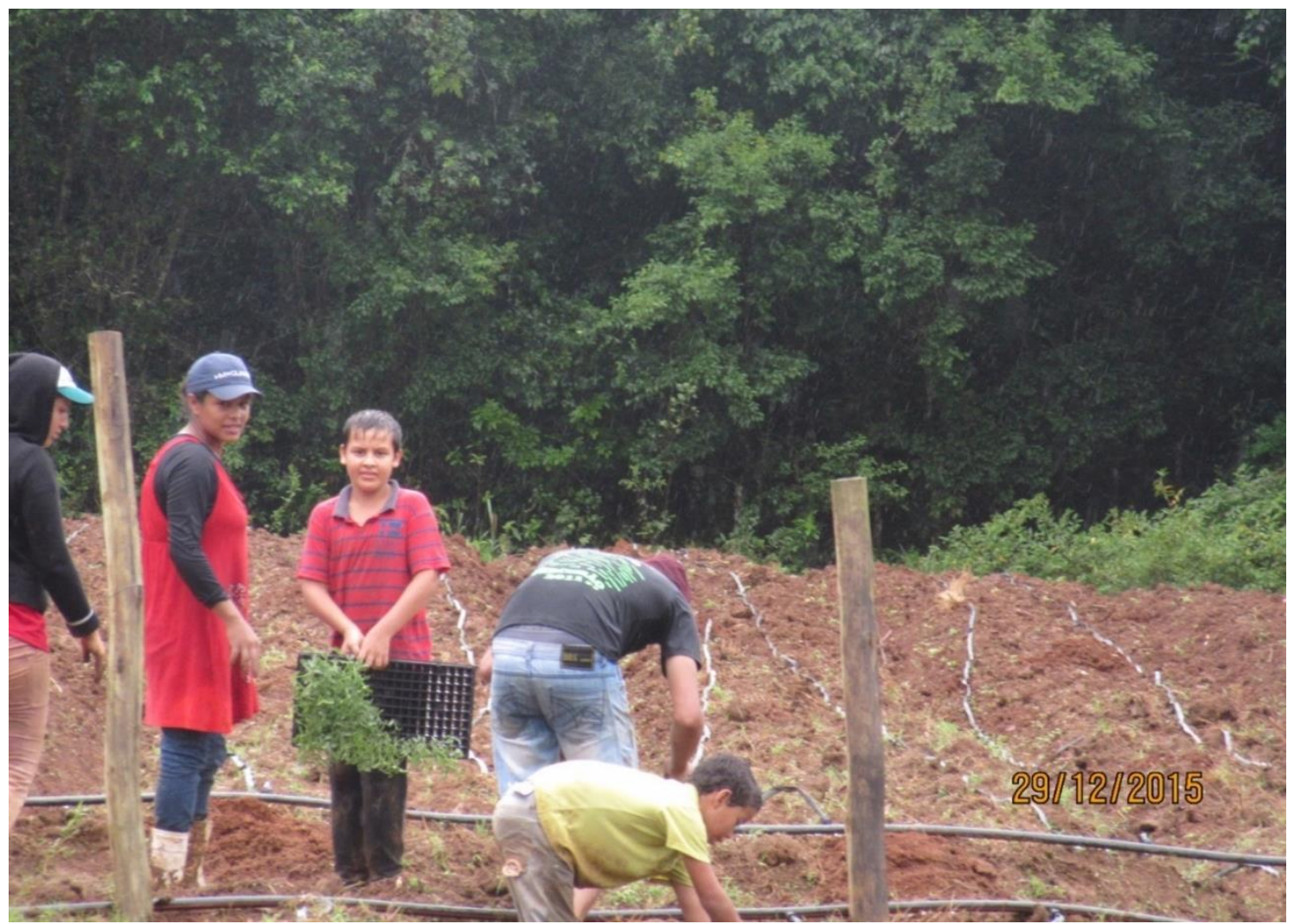

Foto 10: Crianças camponesas na plantação de tomates: toda a família trabalha. Associação dos Produtores da Microbacia do Rio Apiaí Guaçu - Banco da Terra, bairro Coimbra. Foto: Lucinei Paes de Lima, dez. 2015. 


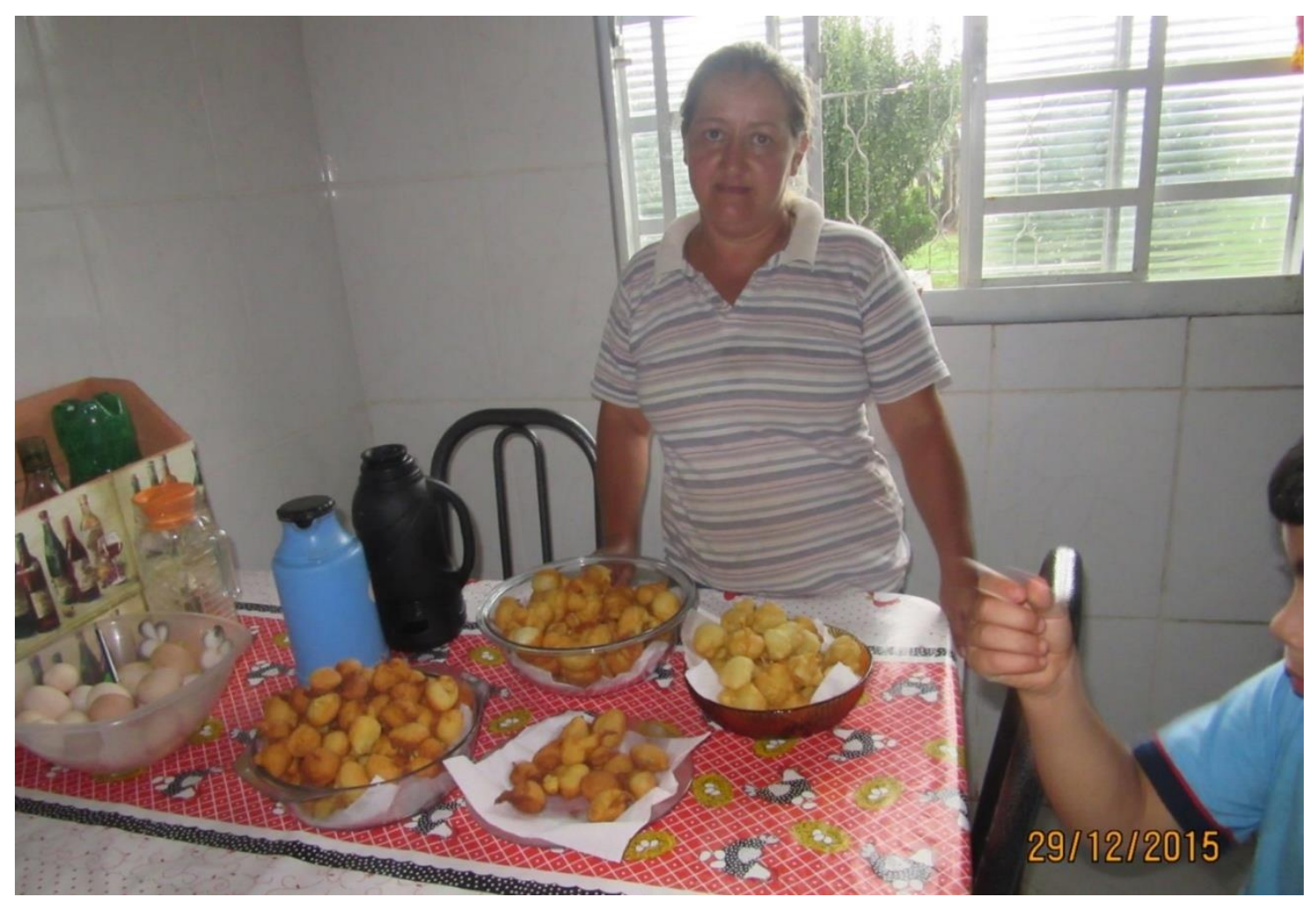

Foto 11: Lucimara Barros e os bolinhos de chuva preparados para o café coletivo. Associação dos Produtores da Microbacia do Rio Apiaí Guaçu - Banco da Terra, bairro Coimbra. Foto: Lucinei Paes de Lima, dez. 2015.

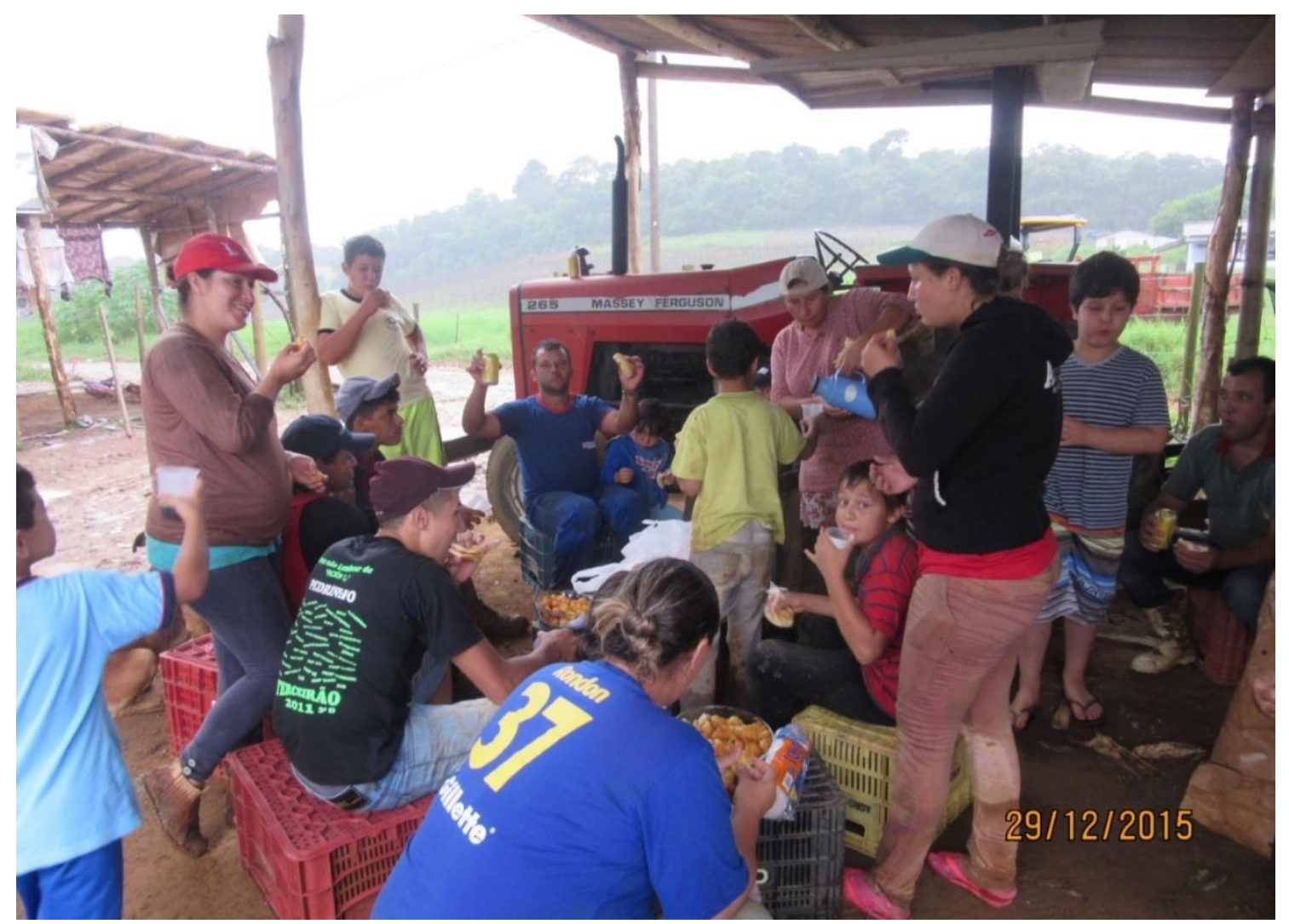

Foto 12: Confraternização depois do plantio coletivo do tomate. Associação dos Produtores da Microbacia do Rio Apiaí Guaçu - Banco da Terra, bairro Coimbra.

Foto: Lucinei Paes de Lima, dez. 2015. 
Um camponês no município de Ribeirão Branco não costuma assalariar outro camponês. Eles trabalham com pagamentos de "dias de serviço", feito em dinheiro, sempre que a família precisa concluir o trabalho em tempo hábil. É o que nos explica o Sr. Leonil Gonçalves, que mora no bairro do Caçador Taquarizinho, em Ribeirão Branco: “Ah, quando a gente não está vencendo a colheita, a gente chama algumas pessoas do bairro que estão meio de folga para ajudar. Aí a gente paga o dia deles” (Entrevista com Leonil Gonçalves, mar. 2015). ${ }^{9}$

Segundo o Sr. Leonil, na maioria das vezes os camponeses buscam esse apoio para a colheita, pois é preciso "passar a roça toda" para garantir que não fique tomate maduro no pé sem ser enviado ao mercado. Para esse serviço, a forma de pagamento mais utilizada é um valor estabelecido por caixa colhida. Uma caixa de tomates tem cerca de $25 \mathrm{~kg}$ e o valor pago em 2015 para aqueles que trabalharam somente na colheita foi de 1 real por cada caixa colhida. $\mathrm{Na}$ Foto 13, o Sr. Valdinei Jesus colhe o tomate no bairro Coimbra. Ele afirma que um bom colhedor é capaz de colher cerca de oitenta a noventa caixas por dia, mas depende de como está a saúde da lavoura.

Para a colheita do tomate, costumam utilizar um saco, geralmente de algodão, mas que também pode ser feito da embalagem de adubos, onde são acomodados os tomates a cada rua colhida. Eles o chamam de "colada". As duas mãos ficam livres para apanhar o fruto e, aos poucos, vão completando o saco, que é despejado numa caixa plástica para, depois, ser classificado.

$\mathrm{Na}$ Foto 16, podemos observar uma roça de tomates e, na Foto 15, as caixas sendo empilhadas, à espera do trator que as recolhe e leva para o barracão onde o tomate é selecionado e classificado por tamanhos e cores. É dessa forma que o enviam para o Ceasa.

Durante as nossas visitas nas roças de tomate, foi possível sentir o cheiro intenso dos agrotóxicos aplicados para combater as pragas que, segundo os camponeses entrevistados, são muitas para essa cultura. Por esse motivo, com objetivo de combatê-las e garantir uma produção maior, eles aplicam esses venenos dia sim, dia não, a depender do estado da proliferação das pragas.

\footnotetext{
${ }^{9}$ Essa entrevista aconteceu durante uma manifestação dos camponeses pela continuidade do Programa Minha Casa Minha Vida Rural na Avenida Paulista, em São Paulo-SP. O Sr. Leonil é um camponês proprietário de terra (herança da família da sua esposa), mas nos contou que se assalaria nas fazendas de tomate durante a safra.
} 


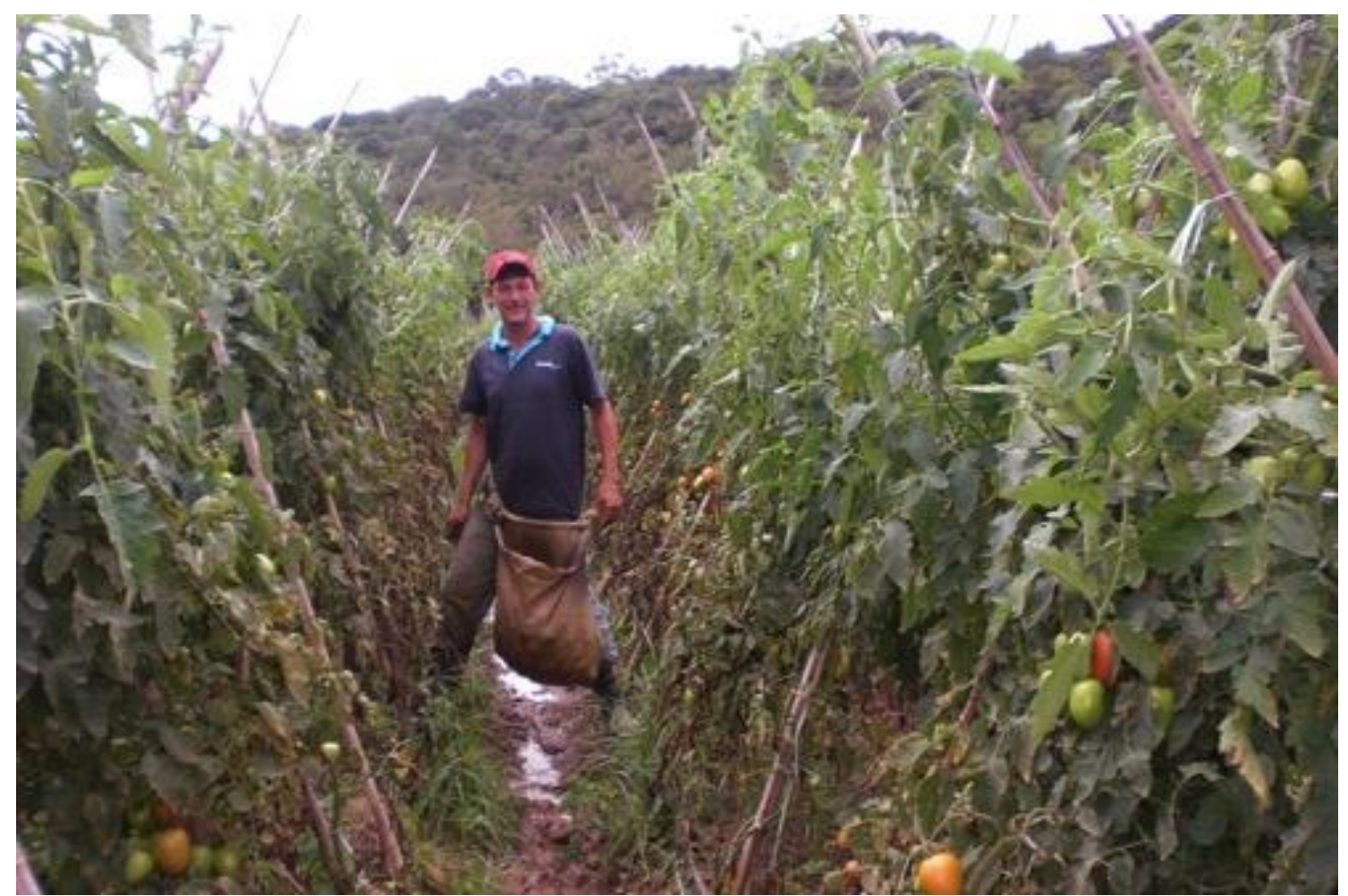

Foto 13: Valdinei de Jesus colhendo tomate. Associação dos Produtores da Microbacia do Rio Apiaí Guaçu - Banco da Terra, bairro Coimbra. Foto: Lucinei Paes de Lima, mar. 2015.

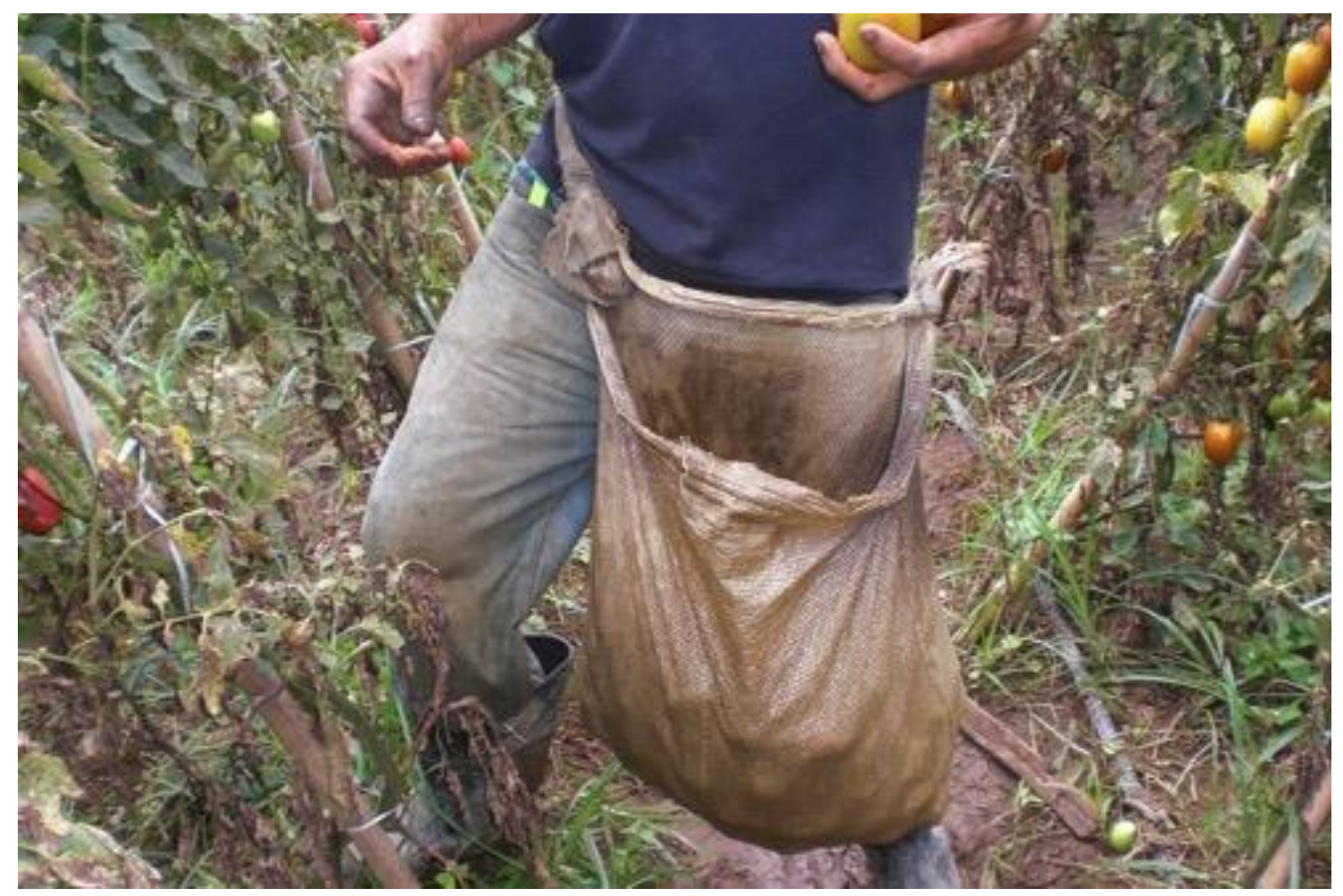

Foto 14: Colada utilizada para colher os tomates. Associação dos Produtores da Microbacia do Rio Apiaí Guaçu - Banco da Terra, bairro Coimbra. Foto: Lucinei Paes de Lima, mar. 2015. 


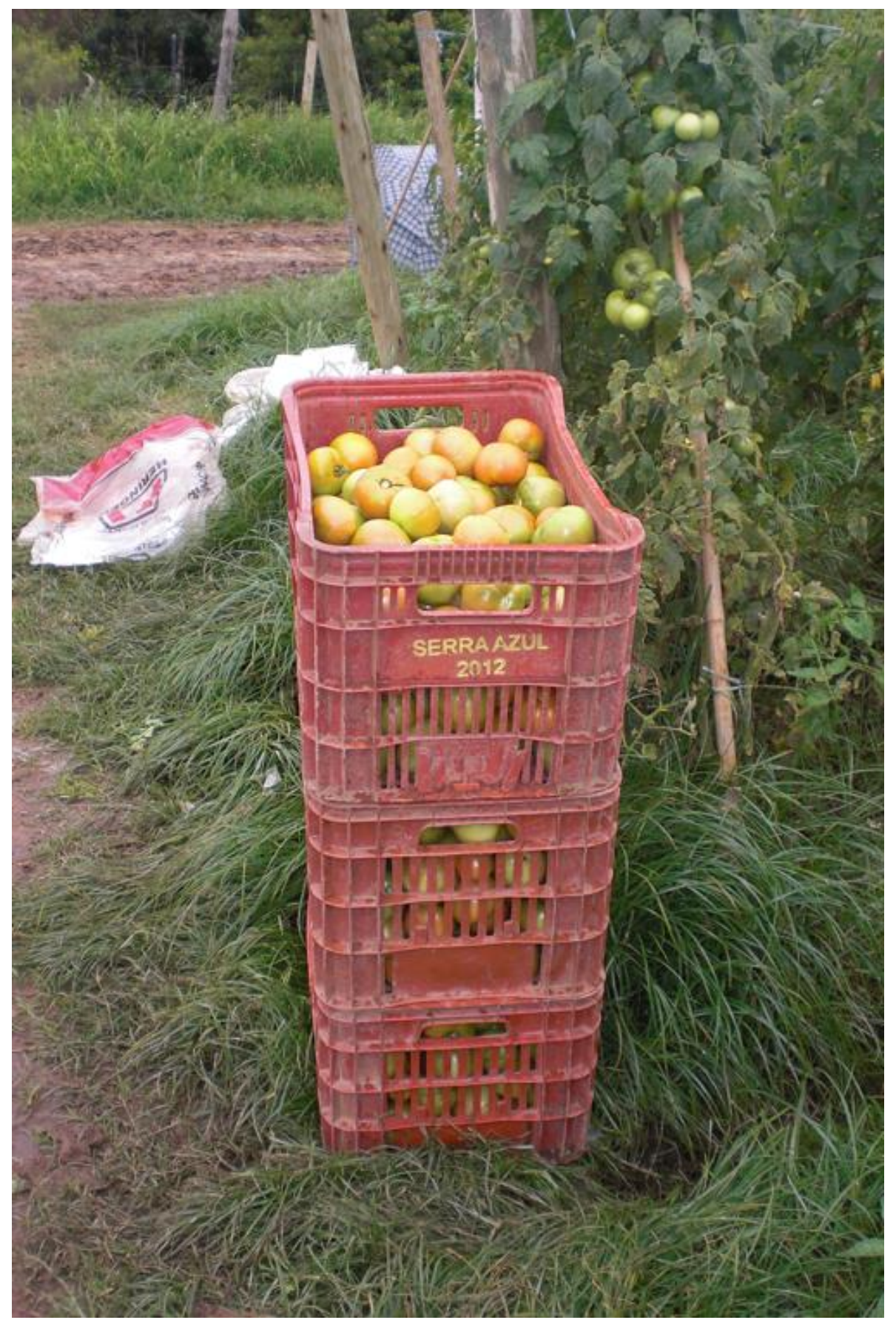

Foto 15: Caixas com tomates colhidos. Associação dos Produtores da Microbacia do Rio Apiaí Guaçu - Banco da Terra, bairro Coimbra. Foto: Lucinei Paes de Lima, mar. 2015. 


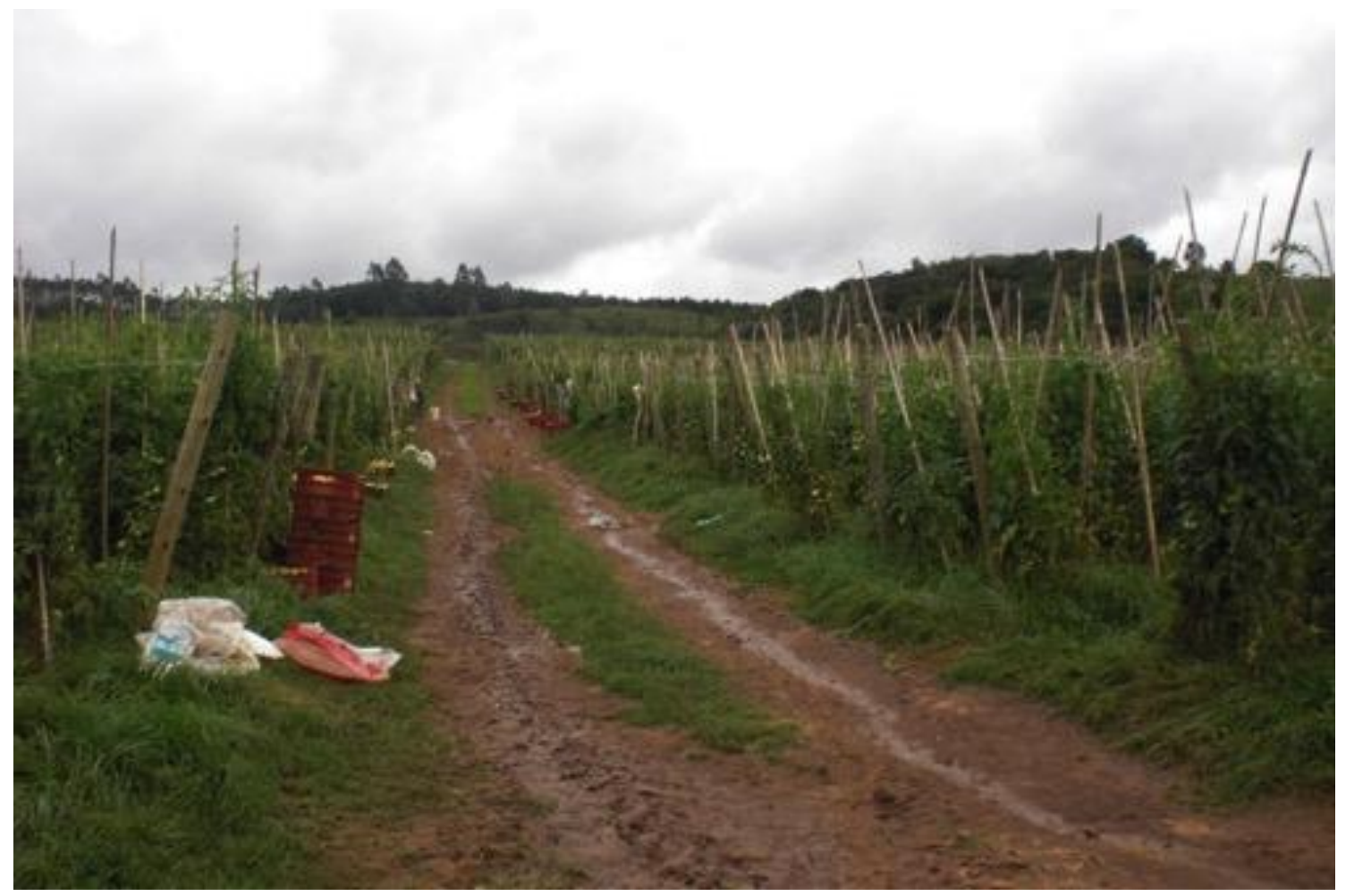

Foto 16: Roça de tomate. Associação dos Produtores da Microbacia do Rio Apiaí Guaçu Banco da Terra, bairro Coimbra. Foto: Lucinei Paes de Lima, mar. 2015.

Conversamos com a camponesa Luciane Cardoso que nos explicou sobre os custos da sua plantação de tomates. Segundo ela, o tomate fica caro para produzir e, por isso, a maioria dos camponeses depende de financiamentos do Pronaf, executados pelo Banco do Brasil.

Ninguém produz menos que mil pés de tomate, então, para produzir mil pés de tomate, a gente gasta 2,5 mil reais. Em média, se colhe 300 caixas por mil pés, então se pega e faz a conta, que fica 8,33 reais por cada caixa de tomate. Mas aqui não coloca o salário da gente mesmo. O mais caro são os venenos que usa. Por exemplo, um litro do veneno Belt ${ }^{10}$ custa 570 reais e dá para passar poucas vezes na roça toda, porque a medida dele é de 100 litros de água, você coloca $40 \mathrm{ml}$ dele. É veneno para matar os bichos, para broca. (Entrevista com Luciane Cardoso, bairro Coimbra, mar. 2005)

A Sra. Luciane Cardoso nos contou que, numa única aplicação de agrotóxico, eles combinam até seis tipos de venenos ao mesmo tempo. "Ontem mesmo colocamos Fegatex ${ }^{11}$, Score $^{12}$, Trebon ${ }^{13}$, Sumidan $^{14}$ e Marshall ${ }^{15}$ ". As classificações desses venenos podem ser

\footnotetext{
${ }^{10}$ Ver: <http://www.adapar.pr.gov.br/arquivos/File/defis/DFI/Bulas/Inseticidas/belt_.pdf>.

${ }^{11}$ Ver: <http://www.br3.ind.br/pg.php?pg=5\&int=produtos $>$.

${ }^{12}$ Ver: <https://www.extrapratica.com.br/BR_Docs/Portuguese/Instructions/62.pdf>.

${ }^{13}$ Ver: <http://www.adapar.pr.gov.br/arquivos/File/defis/DFI/Bulas/Inseticidas/TREBON100SC.pdf〉.

${ }^{14}$ Ver: <http://www.adapar.pr.gov.br/arquivos/File/defis/DFI/Bulas/Inseticidas/SUMIDAN_25_EC.pdf >

${ }^{15}$ Ver: <http://www.adapar.pr.gov.br/arquivos/File/defis/DFI/Bulas/Inseticidas/MARSHAL_400_SC.pdf>.
} 
observadas nas notas de rodapé. Entre os fabricantes, destacam-se as empresas Bayer e Syngenta.

O depoimento da Sra. Luciane é revelador quanto ao uso indiscriminado de agrotóxicos nas lavouras de tomates.

Vale dizer que além dos problemas de saúde e ambientais que os agrotóxicos acarretam, existe o fato de os camponeses, ao contraírem o financiamento no Banco do Brasil pelo Pronaf para a produção de tomates, serem obrigados a garantir que um percentual desses recursos seja transferido diretamente para as empresas de insumos e venenos. $\mathrm{O}$ uso de agrotóxico nas lavouras é uma condição que o banco impõe para a liberação do financiamento, exigência de "garantia" de que a lavoura tenha boa produtividade (salvo intempéries naturais).

Conforme nos foi dito, o banco do Brasil faz a mediação entre os pequenos produtores e as multinacionais, fabricantes de veneno, ao exigir que um percentual do financiamento seja destinado a adubo e fertilizantes. Disseram que, para tirar o financiamento, o banco só o aprova para o plantio de tomate e algumas outras poucas culturas, como vagem e pimentão, que também oferecem risco de endividamento para os pequenos produtores, como nos afirma o $\mathrm{Sr}$. José Vicente, diretor do Sindicato de Empregados Rurais de Ribeirão Branco e Guapiara:

O banco trabalha com a lógica toda contra os pequenos produtores. Por exemplo, se você pede um financiamento de 25 mil reais pra plantar tomate, que é alto custo e alto risco para o trabalhador, o banco libera em dez e em quinze dias o dinheiro está na sua conta. Mas isso é pra produção de tomate! Agora, se você quiser dinheiro pra investimento, que é muito mais seguro, e pedir esse mesmo valor, o banco demora seis a doze meses para analisar e te dar a resposta, e nem libera! Aqui a maioria do Pronaf só sai para o plantio do tomate, e aí também um pouco para vagem ou pimentão.

É estranho o banco dizer que o investimento é mais risco, mas não sei onde tá esse risco? Veja bem, se pego 25 mil reais pra pagar em cinco anos! Enquanto pro tomate pego os mesmos 25 mil reais pra pagar em um ano? Então pra mim, o risco pro banco é maior com tomate!

O problema é que o banco trabalha numa lógica tão errada que, veja bem, um trabalhador assalariado rural (aqui tem muita gente assim), ele tem a terrinha dele, mas está descapitalizado e está temporariamente como assalariado. Pra ele investir e voltar a produzir para ele, precisaria de uns 6 mil reais pra comprar pequenos equipamentos, como um conjunto de irrigação e pulverização. Mas se ele for no banco pedir isso, ele não consegue de jeito nenhum! Mas se for pegar os mesmos 6 mil reais de custeio, o banco liberar pra ele, entendeu? Pra o pequeno se enterrar ainda mais, ficar endividado! Precisa de conversar sobre isso! Porque a questão é que ele precisa de 6 mil reais para adquirir pequenos equipamentos, porque a terra dele também é pequena e não precisa do trator de última geração! Mas ele vai lá muitas vezes e compra o trator que quase nem cabe na terra dele porque ele vê o fazendeiro do lado fazendo e ele quer um daquele, é aí que se endivida inteiro!

Então aquele que quer ser capitalista vai e se ferra, e olhe só! Muitos desses, quando tem oportunidade de assalariar e virar patrão, ele o faz... se puder 
explorar e ganhar dinheiro, ele o fará. (Entrevista com José Vicente, 5 jan. 2016)

Segundo os próprios produtores, o custo desse pacote tecnológico na produção chega a até $50 \%$ dos gastos da lavoura. Ocorre, dessa forma, um percentual alto de transferência do financiamento do pequeno produtor ao capital industrial.

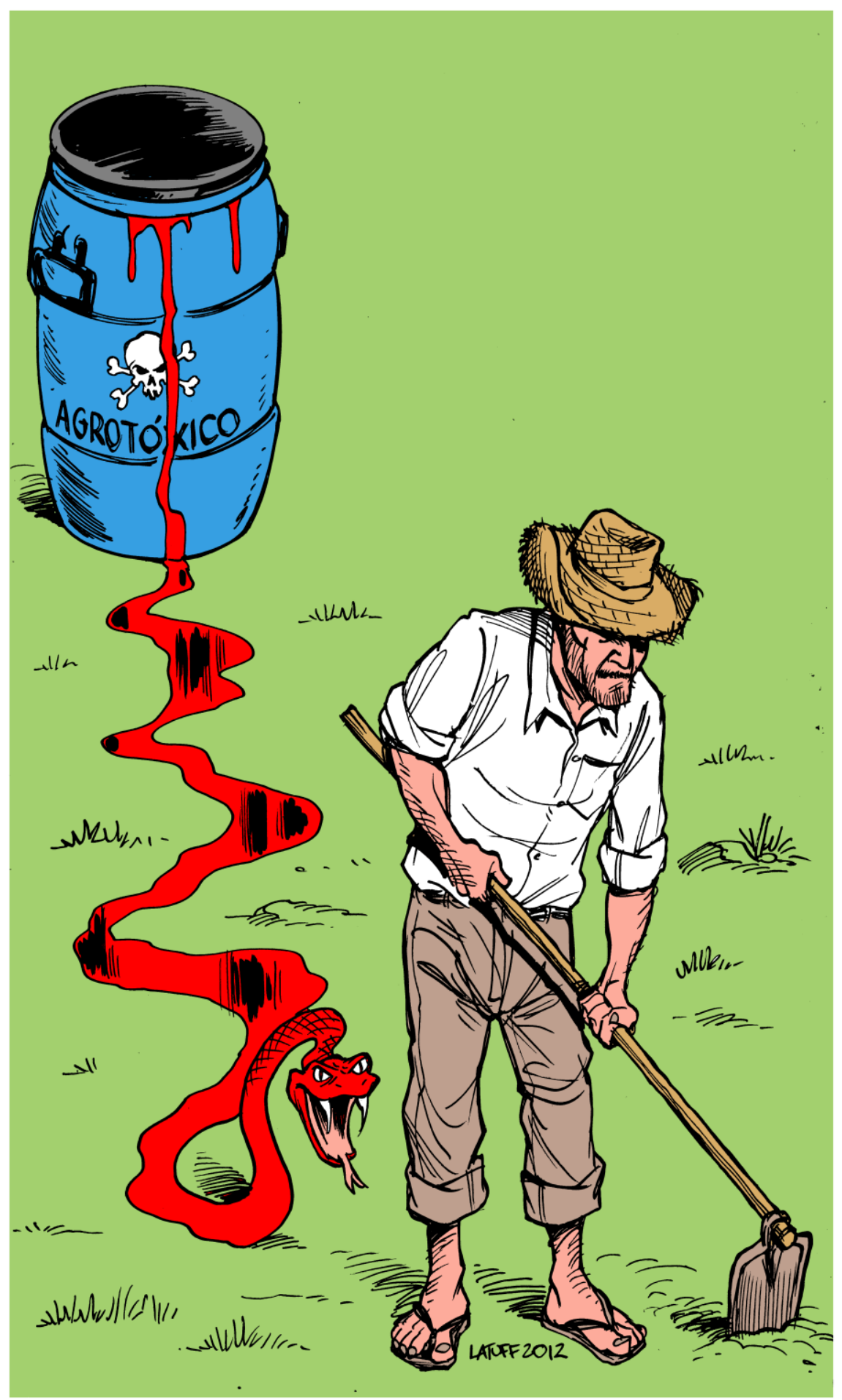

Figura 14: Charge de Latuf, 2012 (apud CUT, 2015). 
Vale ressaltar que todos os camponeses produtores de tomate que entrevistamos utilizam agrotóxicos. Não tivemos relatos sobre produção orgânica desse produto em Ribeirão Branco. Além disso, grande parte desses camponeses não conhece os riscos aos quais estão expostos:

Agricultoras e agricultores familiares adquirem, transportam, armazenam, manuseiam e aplicam venenos com grande frequência. As trabalhadoras(es) e consumidoras(es), do campo e das cidades, das águas e das florestas, se somam a esta cadeia, adquirindo os produtos, levando-os para a casa, sabendose que não há eliminação segura desses contaminantes. (CUT, 2015, p. 12) ${ }^{16}$

A discussão sobre o uso de agrotóxicos é um assunto que permeia a produção dos camponeses. Como nos afirmaram, são tecnologias muito caras para eles e que vêm alterando o solo, a água e a diversidade do meio ambiente. Além disso, nos contaram também sobre o problema do uso das sementes: está havendo uma diminuição na variedade das espécies que, por décadas, eram cultivadas. Com isso, os pequenos agricultores precisam, todos os anos, comprar novas sementes das indústrias, como, por exemplo, as sementes de milho.

Ainda ouvimos relatos sobre o uso de venenos que são proibidos, mas que podem ser facilmente comprados. Ou seja, os camponeses acabam fazendo parte desse negócio e servindo aos interesses das empresas transacionais. Segundo Bartra (2011), os camponeses adequam-se ao mercado convencional e, nessa inserção, onde não se distingue a produção camponesa da produção capitalista, os camponeses são levados a uma disputa desigual dentro da lógica da agricultura de modelo empresarial:

Por ser inevitável adequar-se produtivamente aos sinais do mercado no que estes têm de racional e indicativo das características da demanda, é completamente insuficiente quando o comércio que realmente existe, longe de ser livre, está preso aos interesses das megacorporações, de modo que o excedente agregado pela conversão talvez não termine nas mãos dos rústicos camponeses, mas sim nas das transacionais agroalimentares.

A estratégia de ligar cadeias produtivas, sustentadas em monoculturas especializadas com lógica empresarial, esbarra no iníquo e imprevisível mercado real que castiga os que colocam todos os ovos na mesma caixa. Além disso, choca-se com a racionalidade de um camponês que, diferentemente do empresário, não pode ajustar-se mais às sinalizações do mercado, já que é movido pelo bem-estar da família e não pela rentabilidade, cujos recursos não são livres e monitorizáveis como os do capital, mas estão vinculados. Por último, também se tropeça na mãe natureza, ou seja, na diversidade agroecológica incompatível com a uniformidade técnica da agricultura de modelo empresarial. (BARTRA, 2011, p. 315)

\footnotetext{
16 Para mais sobre $\quad$ o $\quad$ assunto, ver: <http://cut.org.br/system/uploads/action_file_version/0ea6be839abc77dafbbc3f3900958d2c/file/cartilha-cutagrotoxicos-2.pdf $>$.
} 


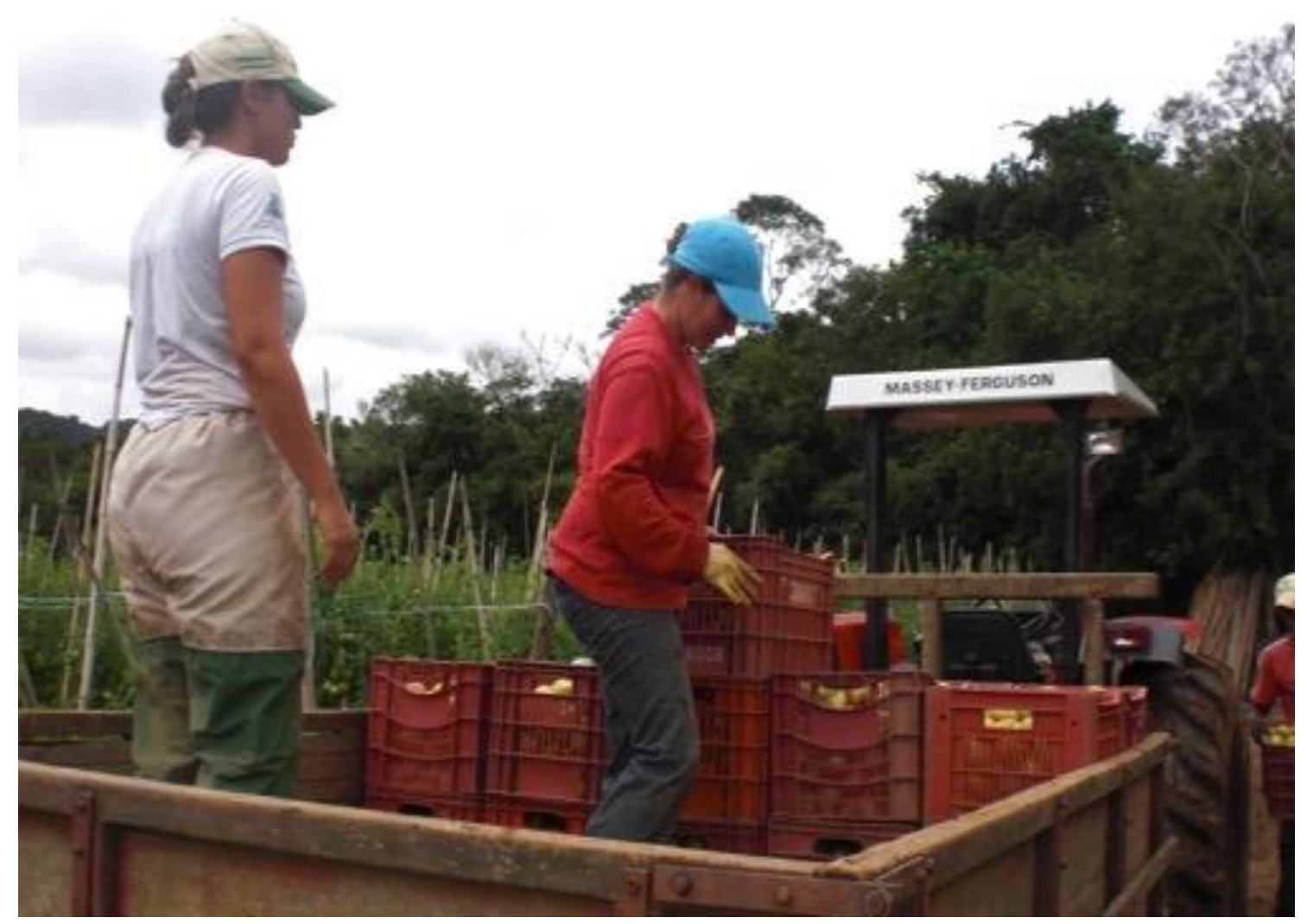

Foto 17: Mulheres recolhendo a produção de tomates logo depois de colhidos. Associação dos Produtores da Microbacia do Rio Apiaí Guaçu - Banco da Terra, bairro Coimbra. Foto: Lucinei Paes de Lima, mar. 2015.

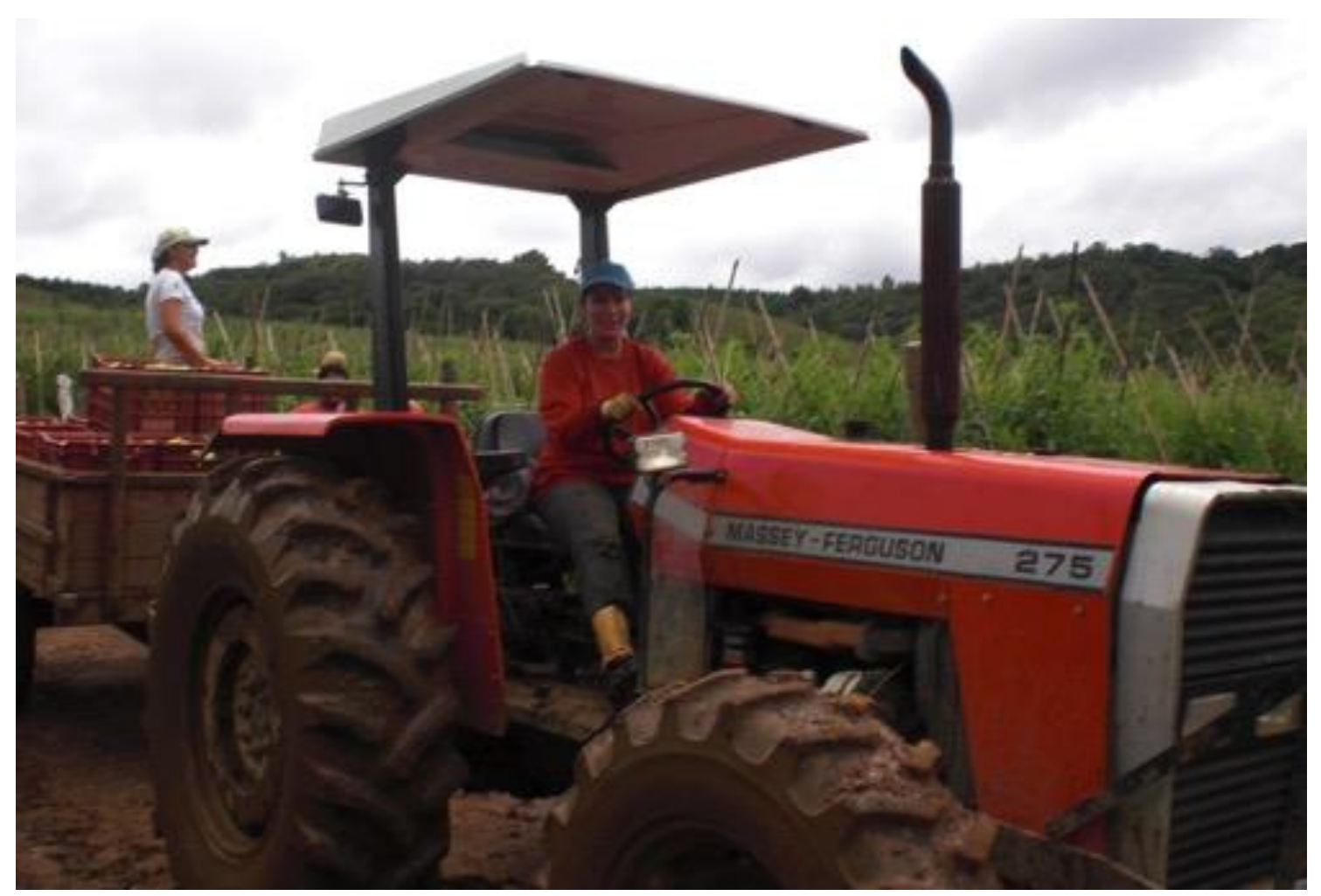

Foto 18: Sra. Luciane conduz o trator com a sua produção para seleção e embalagem. Associação dos Produtores da Microbacia do Rio Apiaí Guaçu - Banco da Terra. Foto: Lucinei Paes de Lima, mar. 2015. 
Observamos que a maioria dos camponeses visitados possuíam hortas e pomares de frutas livres de agrotóxicos para o consumo próprio. Já a produção para o mercado é toda realizada com agrotóxicos pois, segundo os camponeses entrevistados, as terras estão muito contaminadas e as pragas tomam conta de toda a plantação quando se trata de maiores quantidades.

Por último, ainda sobre os agrotóxicos, é preciso registrar que, quando questionados sobre o seu uso, alguns camponeses disseram não gostar de trabalhar dessa forma e que o principal motivo pelo qual não trabalham com orgânicos é pela total falta de apoio. Segundo eles, caso houvesse programas de incentivo e assistência técnica específica para a produção agroecológica, poderiam buscar produzir sem agrotóxicos. É preciso que se diga ainda que, em Ribeirão Branco, o trabalho nas hortas e nos quintais, quando livres de agrotóxicos, são, na sua maioria, comandados pelas mulheres, que se dedicam à produção de alimentos para o consumo da própria família.

Encontramos em Ribeirão Branco algumas mulheres que trabalham sozinhas ou com os filhos em suas plantações de tomates. Elas plantam, colhem, embalam e negociam o preço dos seus produtos. Na maioria desses casos, o marido é assalariado em outro lugar e elas plantam para ter a sua própria renda e trabalhar de forma autônoma.

A Sra. Luciane Cardoso, da Associação dos Produtores da Microbacia do Rio Apiaí Guaçu - Banco da Terra, bairro Coimbra, nos contou que tem experiência em produzir tomates e que a adquiriu trabalhando com seus pais. "Produzo tomates porque esse produto é de ciclo curto e, se o preço estiver bom, mesmo com pouca produção é possível render um bom dinheiro". Ela nos disse que o preço do tomate tem se mantido estável e, com isso, reformou a sua casa, comprou carro e até trocou o trator.

Encontramos, ainda, duas cunhadas da Sra. Luciane que também plantam tomate sem os respectivos maridos, que trabalham como assalariados nas fazendas. As duas possuem filhos pequenos e têm menos de 35 anos de idade cada uma. Perguntamos como faziam para trabalhar mesmo com filhos pequenos e elas disseram que eles ficam com as suas mães e sogras quando não estão na escola.

Luciane nos falou que elas tiram financiamento do Pronaf para produzir e que gostam de trabalhar perto uma da outra, pois, quando uma está com muito serviço, as outras ajudam no trabalho. Sobre a comercialização da produção, Luciane fez a seguinte ponderação:

É a gente que assume tudo para a produção ir para o Ceasa. Além de tudo, ainda temos que pagar a caixa, 3 reais; e o frete, mais 4 reais por cada caixa! Então, pra você vê, é duro! 
Já aconteceu de companheiro nosso vender e tombar o carro na estrada e perder tudo; também já aconteceu de o atravessador voltar e dizer que perdeu tudo porque o mercado estava cheio de tomate e não deu para vender, perdeu tudo no caminhão, nem saiu do caminhão! Perdeu tudo! (Entrevista com Luciane Cardoso, mar. 2005)

Durante as entrevistas, mais de uma vez ouvimos as reclamações dos camponeses sobre a venda da produção para os atravessadores que levam a mercadoria sem confirmar o preço que irão pagar e só voltam depois, com o preço que eles próprios definem. Os camponeses que possuem maior articulação conseguem negociar preços melhores durante a colheita; outros acabam vendendo por um preço muito abaixo. Segundo a camponesa Luciane, são eles próprios que pagam por todas as despesas de frete e, caso aconteça algo de errado durante a viagem, são eles que ficam com o prejuízo. Desse modo, chama a nossa atenção o ganho do atravessador, que não corre risco de prejuízo nessa intermediação.

Conversamos com a Sra. Zeli, do bairro do Caçador. Ela e o marido moram e trabalham nas terras que receberam de herança do seu sogro. Eles trabalham juntos, mas ela nos disse que participa das negociações e fica cobrando os atravessadores para que paguem o preço mais justo:

Eu ligo todo dia no mercado e para o comprador [atravessador] para saber o preço que tá pegando lá em São Paulo. Eu não dou sossego não, vou na cidade e pergunto pros outros. Tem dia que vou na cidade só para isso, saber o que é que tão falando dos preços das coisas que a gente tem para vender, e eu fico no pé até me pagar tudo! (Entrevista com Zeli Santo, bairro do Caçador, dez. 2015)

A Sra. Zeli nos mostra que ela busca os meios possíveis para que a família consiga vender o seu produto por um preço melhor. Encontramos mulheres que protagonizam a produção e comercialização dos seus produtos com autonomia e independência dos seus maridos.

\subsection{Diversificação da produção}

Nesta parte do estudo, trabalharemos principalmente com entrevistas colhidas durante os trabalhos de campo. Os depoimentos que iremos apresentar foram fundamentais para a análise da realidade camponesa em Ribeirão Branco, pois revelam as percepções dos próprios camponeses e nos conectam de maneira mais direta a esse modo de vida extremamente diversificado. Como afirma Shanin:

Outra importante característica a ser destacada a partir dos acontecimentos dos séculos XX e XXI é que as comunidades camponesas demonstram uma real habilidade para se ajustar a novas condições e também uma grande 
flexibilidade para encontrar novas formas de se adaptar e ganhar a vida. Em alguns lugares, há comunidades de camponeses que hoje vivem principalmente do turismo. Há lugares onde as comunidades camponesas ganham a vida com novos métodos de produção e, em outros, os camponeses ganham a vida por meio da combinação do trabalho camponês e do trabalho não-camponês. (SHANIN, 2008, p. 24-25)

Uma das visitas que fizemos foi com a Sra. Maria Camargo, que reside bairro dos Boavas. Ela é muito conhecida no município e também em municípios vizinhos pelo fato de produzir farinha de monjolo que, segundo ela própria, é bem difícil de encontrar nos dias de hoje. Maria nos contou que frequentou a escola até a terceira série e o seu marido, até a quarta série. Juntos, tiveram quatro filhos, mas nenhum mora mais no bairro. Ela nos relatou que trabalha com a produção de farinha há vinte anos e que trocou a roça por esse ofício porque o marido teve um problema de saúde e não podia mais trabalhar. Diante da dificuldade, ela buscou essa alternativa que, na sua opinião, "teria dado muito certo".

Sobre a sua rotina de trabalho, Maria nos contou que, quando é o dia de fazer a farinha, ela trabalha o dia inteiro, das 6 horas até as $18 \mathrm{~h} 30$, no paiol do monjolo que soca o milho e onde também fica o forno que serve para torrar a farinha. Ela vende cerca de 70 litros de farinha por semana no município de Ribeirão Branco, mas também leva para vender nos municípios vizinhos, como Itararé e Itapeva, além de feiras anuais de artesanato que acontecem conforme calendário estabelecido pelos seus organizadores. Nesse sentido, a Sra. Maria possui relação direta com o mercado onde vende a sua produção. Vejamos em Shanin a definição de mercado enquanto sistema camponês de organização econômica:

Las plazas de mercado están típicamente relacionadas con condiciones en que una gran parte de las mercancías nunca llegan al mercado, pues son consumidas dentro de las unidades familiares. En este sentido, los mercados forman un componente típico del sistema campesino de organización económica, proveyendo un lugar donde los productores primarios venden parte de du producción para obtener dinero en efectivo y complementar la producción hogareña mediante la provisión exterior para las necesidades inmediatas.

Las plazas de mercado también cumplen una serie de funciones "noeconómicas", como centros de contacto inter-aldeano, información, vida social y esparcimiento. (SHANIN, 1976, p. 30)

Além da farinha, a Sra. Maria também produz pamonha e, nas feiras que participa, vende os seus produtos, mas também compra os de outras pessoas. Perguntada sobre os rendimentos da sua produção, ela nos disse que, juntando a farinha e a pamonha, estima uma renda de até mil reais por mês e aponta seguramente que o que mais lhe dá renda é a pamonha, cerca de $70 \%$.

Sobre o processo de fabricação da farinha de monjolo, Maria nos ensinou: 
Eu deixo o milho de molho durante 10 a 12 dias e depois lavo bem para então colocar no monjolo que faz o serviço de socar o milho. Depois, eu passo numa peneira bem fina e daí levo para o forno. Por último, passo de novo numa peneira, mas daí mais grossa, pra ficar no jeitinho de farinha mesmo, e embalo. O resto de tudo que sobra desse serviço, eu dou para as galinhas. (Entrevista com Maria Camargo, 21 jul. 2015)

Enquanto conversávamos, chegou um vizinho chamado Augusto e presenciamos o seguinte diálogo:

- Bom dia! Dona Maria, eu tô vendendo um milho, a senhora não quer comprar um pouco?

- Agora eu tô com bastante aqui, agora eu não posso comprar, Guto, porque comprei do Berto, eu carecia e peguei dele, e já deixei certo de pegar mais 20 sacos. Fica pra próxima agora. Mas, oia, a lenha que comprei de você, essa que tá queimando aí!

- Prestou? Pega fogo bem? Se quiser tem que aproveitar pegar que ainda tem mais lá. Bom, tchau pra vocês!

- Tchau, fio. Quer beiju com café? Oia, o milho agora não posso comprar de você, mas, a lenha, eu vou ficar. Corta e deixa secar lá! E obrigada de você trazê a lenha até o paiol pra mim, pois, pra mim, é difícil carregar tudo e trazer aqui sozinha.

Observamos que o Sr. Augusto foi oferecer o seu produto, no caso o milho, e que apesar de a Sra. Maria não poder comprar, ele acabou fazendo uma venda de outro tipo de mercadoria, a lenha. Esse tipo de negociação nos pareceu ser algo muito comum entre eles.

Continuando a nossa conversa, enquanto a Sra. Maria fazia beiju para nos oferecer, perguntamos sobre os seus momentos de lazer e o que ela fazia nas horas de descanso. Ela disse que costuma ir para as festas das comunidades rurais vizinhas, onde faz amizades e aproveita para vender farinha. Nos contou ainda que estava ansiosa porque havia comprado um pacote da excursão que o seu bairro estava organizando para Aparecida do Norte: "estou guardando dinheiro pra gastar lá”. Esse tipo de excursão para Aparecida nos foi relatado também em outros bairros de Ribeirão Branco e parece ser o lugar mais visitado pelos camponeses que podem arcar com os custos de passagem e acomodações para a família.

Como dissemos anteriormente, o marido da Sra. Maria teve um problema de saúde e tem dificuldades para caminhar, mas, segundo ela mesma nos disse, ele contribui bastante nas tarefas de casa pois, como não pode trabalhar com serviço pesado, limpa, lava a louça, limpa o frango, faz a comida e, quando termina, dá um grito comunicando que o almoço está pronto: “ele só não lava a roupa, o resto faz de tudo".

A entrevista com Maria foi dentro do seu paiol, enquanto fazia a farinha, e, portanto, ao som da água e do monjolo que socava o milho. Ela nos relatou histórias de pessoas que até faleceram por se acidentarem ao passar muito perto do pilão, nos pediu cuidado e passou 
algumas instruções de segurança. Explicou que, para trabalhar ali, era necessário respeito com o monjolo e com o forno, e que algumas vizinhas ficaram doentes por não adotarem medidas como nunca molhar as mãos quando se está mexendo no forno e usar botas para proteger os pés, já que a temperatura dentro do paiol é muito diferente da temperatura fora dele. Por isso, durante a entrevista, tivemos que interrompê-la várias vezes por conta da fumaça e do excesso de calor.

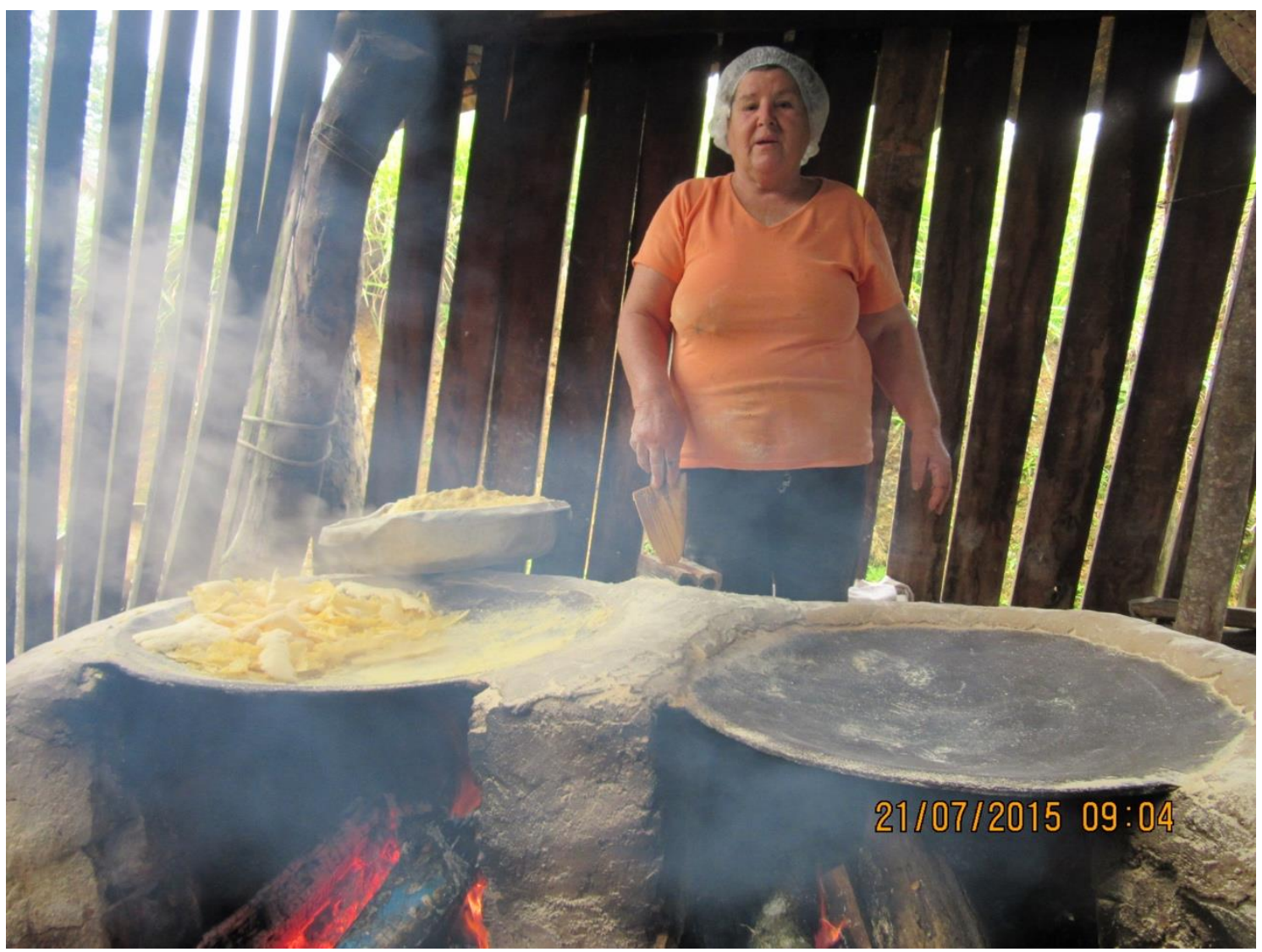

Foto 19: Sra. Maria torrando a farinha no forno, bairro dos Boavas. Foto: Lucinei Paes de Lima, jul. 2015.

Em nossa despedida, Maria nos deu beiju e farinha, e não permitiu pagamento. Pediu somente que trouxéssemos uma foto dela fazendo a farinha, pois ela ainda não tinha nenhuma. Ficamos com o compromisso de voltar.

Como se pode observar, não está se falando de sobras, mas de um dimensionamento da produção que assegure uma reserva a ser eventualmente distribuída. Esse é um dos canais em que a cordialidade camponesa mais se manifesta: é muito difícil deixar um sítio camponês com as mãos vazias e somos testemunhas disso: frutas, verduras, feijão, café, mandioca, ovos, queijo, doce de leite, vassoura, sabão etc. nos foram dados em abundância durante a pesquisa de campo. (PAULINO, 2012, p. 399) 
Realmente saímos de mãos cheias e saciados depois do beiju com café oferecidos por ela, que insistiu para que ficássemos para o almoço - comportamento semelhante encontramos em todas as outras visitas.

O nosso próximo interlocutor é o Sr. Luiz, morador do bairro do Rio Apiaí há mais de quarenta anos. Veio morar sozinho quando era solteiro e comprou o seu sítio de dois alqueires depois de ganhar o dinheiro numa plantação de tomates.

O tomate vicia, quem planta sempre quer plantar de novo e aí é um perigo. Se colocar tudo o que tem ali, você pode perder tudo, então é o causo de você levar controlado, né? Eu já vi gente forte ficar a zero porque deu tudo o que tinha e perdeu tudo! O tomateiro tem duas alegrias na vida: uma quando ganha dinheiro e a outra, que é ainda maior, é quando paga a conta, no acaso do preço quando está muito ruim e você consegue pagá a conta sem ficar devendo, aí fica louco de alegre, numa alegria só, sendo que não ganhou nada! Pra você vê como é! (Entrevista com Luiz Henrique, bairro do Rio Apiaí, 23 jul. 2015)

Encontramos o Sr. Luiz na sua roça de milho, trabalhando na colheita. Para o serviço, ele contava com o trabalho acessório de dois vizinhos, o Dirceu e o Antônio, que foram pagos pelos dias de serviço ao valor de 50 reais cada um. Luiz nos disse que, neste período de entressafra do tomate, costuma sobrar mão de obra, situação diferente do período da safra. Perguntamos sobre sua jornada de trabalho e ele nos contou que costuma ser das $7 \mathrm{~h} 30$ às $17 \mathrm{~h} 30$, com duas paradas, uma às $12 \mathrm{~h}$, para o almoço, e outra às $15 \mathrm{~h}$, para o café da tarde, como é costume na região.

Os trabalhadores que vendem o seu dia de serviço em Ribeirão Branco, como nos foi relatado, são os camponeses mais pobres e, na sua maioria, não são proprietários de terra.

O milho é um produto indispensável para todos os camponeses com os quais tivemos contato durante a pesquisa, assim como feijão. O primeiro, além de servir de alimento antes do seu amadurecimento, também é reservado durante um longo ciclo para alimentar os animais.

Apesar de bastante depreciado no mercado em relação aos demais cereais, o milho é um fundo de reserva importantíssimo, pois garante a alimentação das criações, geralmente dos suínos e galinhas. Apenas eventualmente destinado ao mercado, essas criações são fontes básicas de carne consumida internamente, principalmente quando as famílias são mais empobrecidas e não dispõem de terra suficiente para a manutenção de bovinos para o provimento de carne. (PAULINO, 2012, p. 397)

Na Foto 21, temos uma "bandeira de milho", técnica utilizada durante a colheita: para que não fique tudo espalhado, eles acumulam montes que facilitam o transporte para um lugar protegido de umidade. 


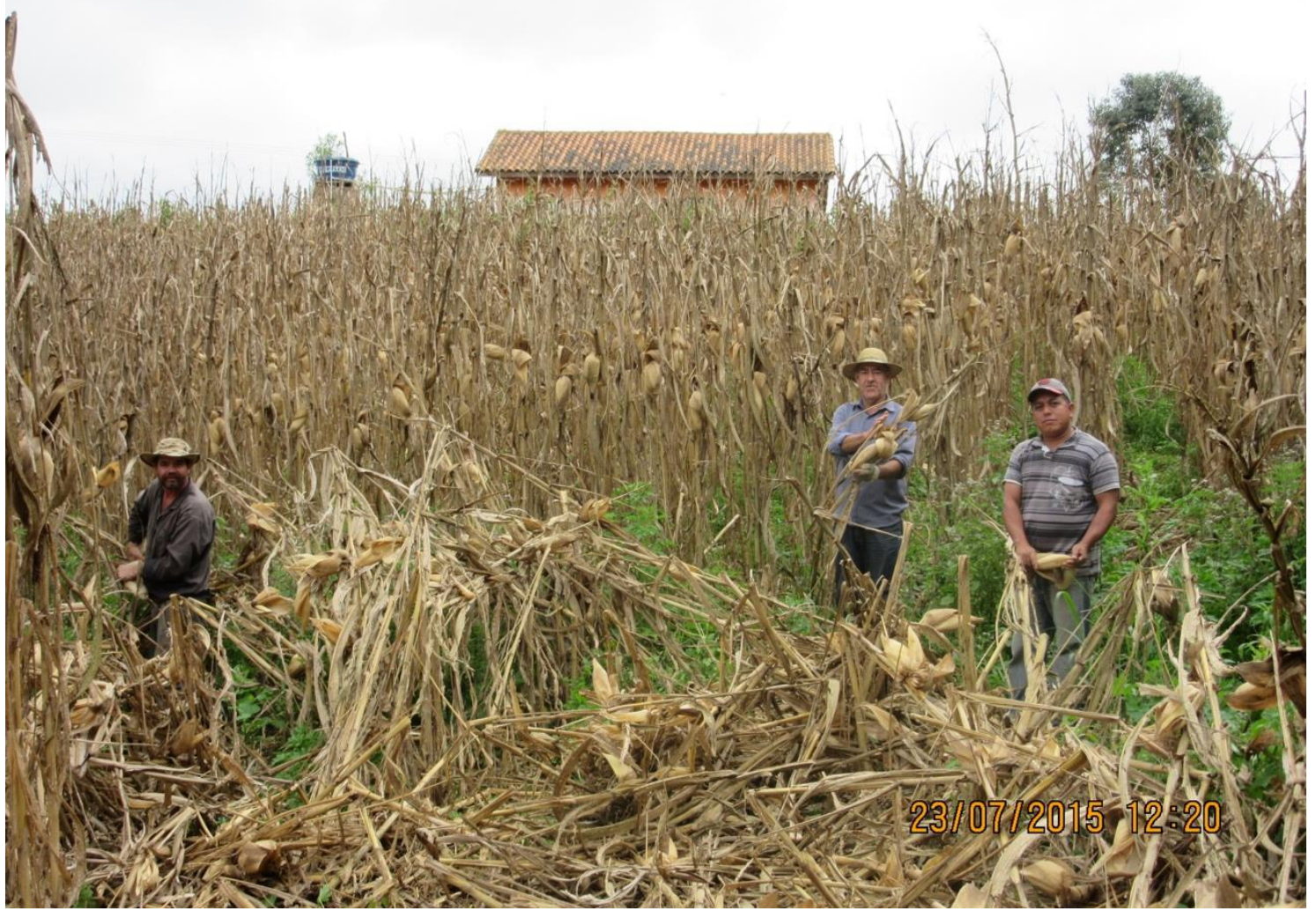

Foto 20: Quebra de milho com uso de trabalho acessório, bairro do Rio Apiaí. Foto: Lucinei Paes de Lima, jul. 2015.

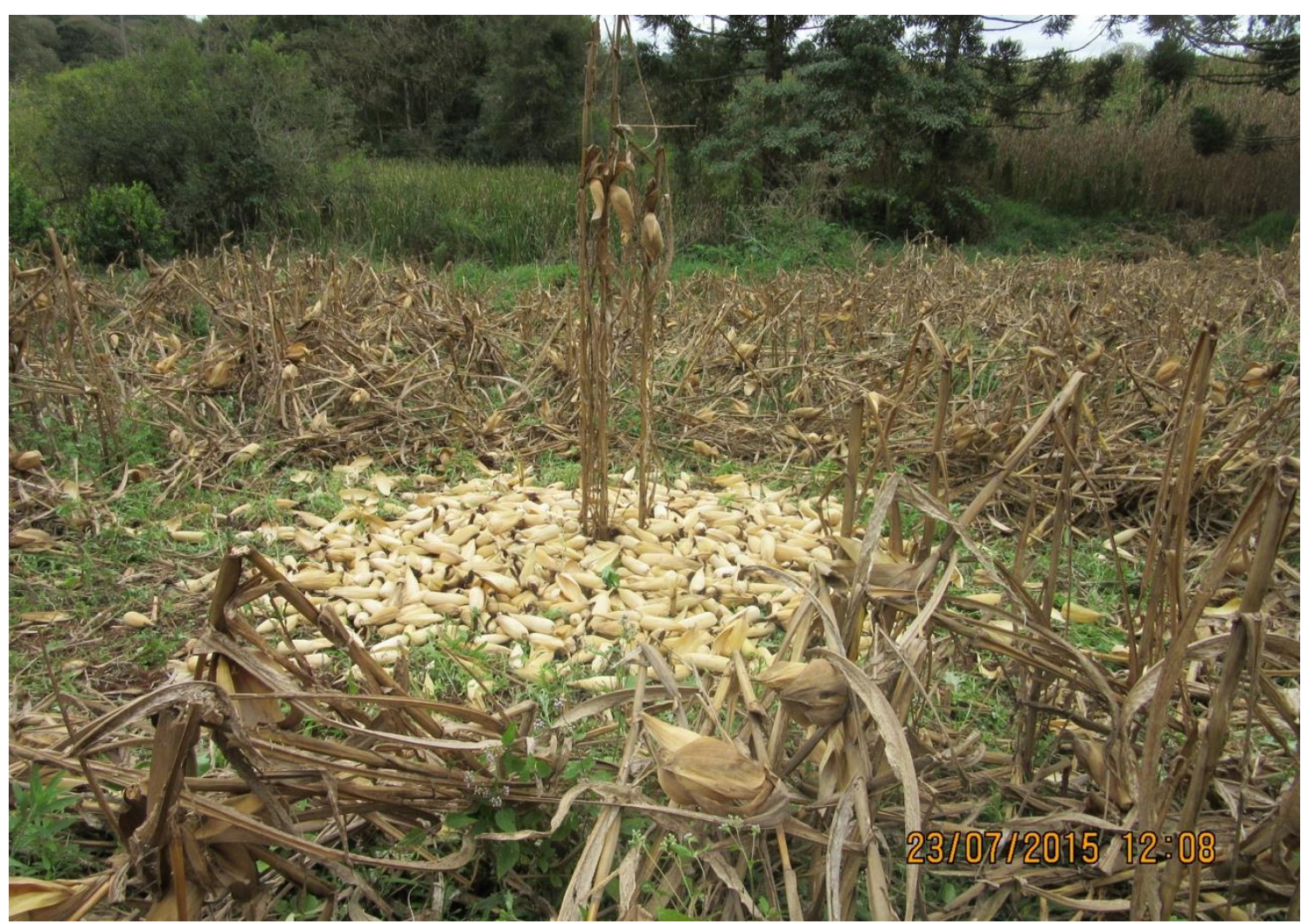

Foto 21: Bandeira de milho, sítio São Luiz, bairro do Rio Apiaí. Foto: Lucinei Paes de Lima, jul. 2015. 
No final do dia, depois da colheita, conversamos um pouco mais com o Sr. Luiz e ele nos contou sobre os resultados da roça de milho que acabara de colher. Segundo ele, plantou e colheu 4 tarefas de milho ${ }^{17}$, que produziram o equivalente a 25 cargueiros (cada cargueiro equivale a $90 \mathrm{~kg}$, portanto, foram produzidos $2.250 \mathrm{~kg}$ de milho). "Vou ficar pro gasto com 15 cargueiros e vender o restante [10 cargueiros]" (Entrevista com Luiz Henrique, bairro do Rio Apiaí, 23 de jul. 2015).

Calcular a terra para o plantio em "tarefas" e vender as sacas de milho em "cargueiros" são referências de cálculos dos camponeses $^{18}$. Tal característica não é exclusividade dos camponeses de Ribeirão Branco:

Quando indagamos sobre os resultados da produção intercalar, via de regra, os camponeses a dimensionam a partir da unidade "carros de milho". Assim, um carro corresponde a 40 balaios ou 10 sacas limpas. Outras vezes, tomamse como referências balaios de milho, sabendo-se que são necessários cerca de quatro balaios para compor uma saca e cerca de 120 espigas para compor um balaio.

É importante destacar que essas medidas referenciam apenas a parte da produção que circula dentro da parte do território dominada pelos camponeses, sendo inclusive utilizada nas negociações feitas em espécie entre eles, bem como em empréstimos a serem saldados nas próximas colheitas. (PAULINO, 2012, p. 415)

Como ele havia acabado de realizar a colheita, perguntamos como era feito o cálculo para saber o que lhe rendeu essa plantação. Supreendentemente, ele nos disse que o milho não dá "lucro" nenhum e que só planta para dar para as criações. Segundo o nosso interlocutor, o milho só traz lucro se plantado em grande escala e nos deu a seguinte explicação:

Imagine que você pega 4 dias de serviço, dá o total de 160 reais, e o milho hoje está sendo vendido a 20 reais o saco na roça. Então, sai tipo 0,33 centavos o quilo.

Vamos supor que eu vendesse tudo os $2.250 \mathrm{~kg}$, que me daria o total de 742,50 reais. Aí você tem que pegar e fazer a soma do que gastou com gradão [trator], adubo, dias de serviço pago para colheita, veneno, semente, e fica assim:

- gradão passado duas vezes na terra porque suja muito: 120,00 reais;

- $5 \mathrm{~kg}$ de semente: 25 reais;

- pagamento de dias de serviço (4 dias): 160 reais;

- herbicidas: 40 reais;

- serviço meu: 50 reais;

\footnotetext{
${ }^{17}$ Uma tarefa de terra corresponde a $750 \mathrm{~m}^{2}$. Um alqueire equivale a $24 \mathrm{mil} \mathrm{m}^{2}$ que, por sua vez, são equivalentes a 32 tarefas de terra. Já um hectare, corresponde a 13 tarefas de terra.

${ }^{18}$ Além de compreender o que seria uma tarefa de terra, durante a entrevista sobre o milho tivemos dificuldades de compreender e chegar a um acordo sobre quantidades e equivalências de valores. Muitas expressões soavam complexas demais para o nosso domínio. Ao explicar quanto seria um cargueiro de milho, nos disseram que, antes, era preciso entender que um atilho é igual a 4 espigas de milho amarradas (antigamente se vendiam assim). Um cargueiro seria vendido pelo que chamam de "mão". Uma "mão" de milho corresponde a 64 espigas. Então, no cálculo correto, um cargueiro corresponde a 8 "mãos", ou seja, 64 espigas vezes 8, ou 512 espigas. Um cargueiro de milho corresponde a $90 \mathrm{~kg}$ de milho debulhado, ou seja, sem a casca e sem o sabugo.
} 
- adubo: 200 reais;

Não vou nem colocar o plantio na terra senão fico até nervoso [risos]. Total de despesas: 595 reais.

Voltamos ao valor do milho colhido:

- total do milho colhido em quilos: $2.250 \mathrm{~kg}$;

- valor do quilo na roça: 0,33 centavos;

- valor total da receita: 742,50 reais.

Resultado final:

- receita: 742,50 reais;

- despesa: 595 reais;

- igual: 147,50 reais.

(Entrevista com Luiz Henrique, 23 jul. 2015)
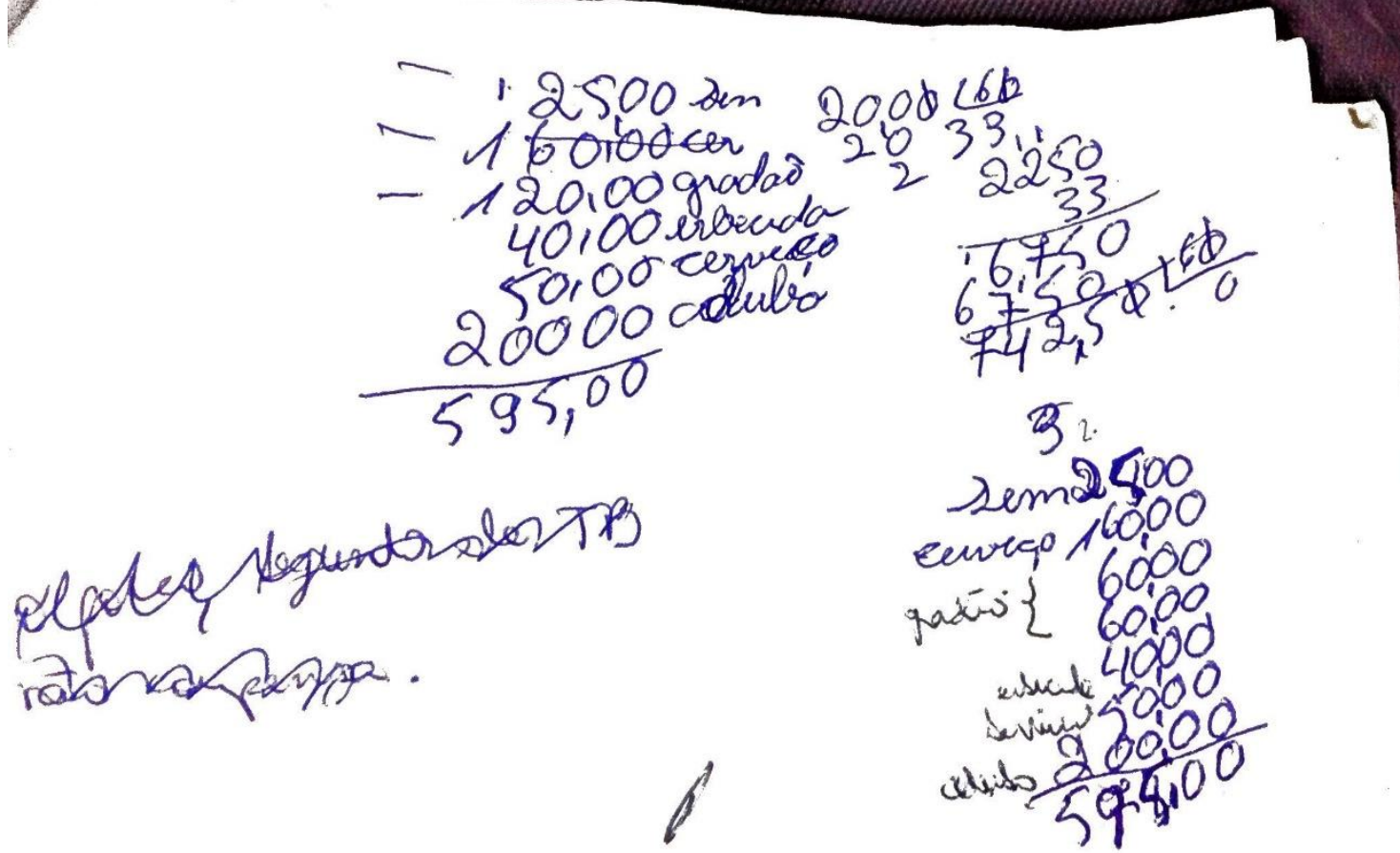

Foto 22: Conta feita pelo Sr. Luiz mostrando a despesa, de 595 reais, a receita, de 742,50 reais, e os 147,50 reais de rendimentos com sua plantação de milho. Bairro do Rio Apiaí, jul. 2015.

Como dissemos anteriormente, o milho, para esses camponeses, significa autonomia, e isso é mais que valor econômico, é garantia de alimento por um longo período de tempo para a sua família e também para os animais de criação.

O resultado da produção do Sr. Luiz nos intriga na medida em que percebemos que ele não inclui o valor do seu trabalho dedicado à plantação - só colocou um dia de serviço. Também observamos que ele faz o cálculo como se fosse vender todo o milho, o que já nos adiantou que não vai fazer e que irá utilizar uma parte dele para alimentar as galinhas. Sendo assim, qual seria o cálculo mais fiel? Shanin nos mostra que pode não haver um cálculo exato no caso da produção camponesa porque o mais importante é o valor de uso dos seus produtos: 
El consumo, más que la acumulación, apunta, en la explotación agrícola familiar, a encontrar expresión en el hecho de que el uso-valor predomina repetidamente sobre el intercambio-valor en la consideración del campesino. (SHANIN, 1976, p. 23)

Buscando compreender essa realidade, questionamos o nosso interlocutor sobre os motivos que o levavam a plantar milho todos os anos, já que o resultado, segundo ele próprio, não era satisfatório. Ele nos relatou que:

O milho, planto uma vez no ano, sempre no mês de agosto e, no mês de janeiro, vem o milho verde que a gente aproveita pra fazer as coisas boas do milho. E no mês de junho e julho é o período de quebrar o milho seco, o milho das galinhas, então a gente passa 12 meses comendo do resultado disso com carne de galinha, ovo, e o que sobra, a gente sempre vende. Então, pra ver, compensa pra ter uma carne, um ovo que não carece de comprar, né? Mesma coisa com o feijão, que também não dá lucro nenhum, mas, se a gente não planta, depois tem que comprar, né? (Entrevista com Luiz Henrique, 23 jul. 2015)

Com esse relato, fica evidente que, quando o Sr. Luiz nos diz que o milho não dá "lucro", ele está se referindo aos valores em dinheiro que obteria caso decidisse plantar apenas para comercializar. O que o motiva a produzir o milho não seria, na verdade, o valor em dinheiro que obteria com uma eventual comercialização, mas a possibilidade de alimentar a sua família com o produto direto de seu trabalho e a economia que realiza ao não precisar comprar tal produto no mercado.

Durante a entrevista, o Sr. Luiz nos disse que tinha uma quantidade média de milho que era suficiente para o abastecimento da família durante os doze meses e que o excedente, na maioria das vezes, é vendido para um vizinho próximo.

Por fim, observa-se que a sua referência de tempo é construída em torno do ano agrícola, a partir do qual é elaborado o planejamento que preside a organização produtiva da unidade. Note-se que esse planejamento contempla os limites da unidade doméstica e se inscreve no circuito da ajuda mútua. Ou seja, há um estoque extra para o caso de algum vizinho precisar, sendo que os acertos igualmente são feitos de acordo com o ciclo das colheitas e calculados em espécie. Desse modo, mesmo que realizados em dinheiro, a referência é o preço ao produtor, e não os preços praticados na cidade. (PAULINO, 2012, p. 396)

Com esse relato, o Sr. Luiz sintetiza o funcionamento da lógica camponesa, de satisfazer a necessidade de consumo da família, considerando o calendário agrícola. No caso do Sr. Luiz, o milho plantado uma única vez ao ano, ou seja, o resultado do plantio deve atender às necessidades de doze meses de consumo.

Conforme Moura, quando esse excedente é vendido, através de transações monetárias, ele será utilizado como meio para aquisição de outros bens: 
Esta "sobra da despesa" é uma quantidade variável do cereal que, de acordo com a lógica das famílias camponesas, "excederá" o consumo doméstico, tomando-se como base um ano alimentar. $\mathrm{Na}$ verdade, trata-se de uma avaliação flexível e subjetiva (no sentido chayanoviano) já que a dependência de bens que devem ser necessariamente adquiridos por transações monetizadas, tais como roupa e remédios, exigirá vendas inevitáveis do cereal, pois que ele funciona como meio de conversão fundamental para aquisição de outros bens. (MOURA, 1978 p. 25-26)

A entrevista com o Sr. Luiz nos apresentou elementos fundamentais para a nossa pesquisa. Observamos que, ao mesmo tempo em que o trabalho é penoso e que a renda é escassa, eles continuam desenvolvendo atividades que garantam a sua autonomia e, desse modo, a reprodução do seu modo de vida.

O bairro da Boa Vista é conhecido pela população do município como o "sertão", o lugar mais distante da cidade. É o bairro de mais difícil acesso e, portanto, o mais isolado do restante do município. Distante cerca de uma hora de viagem até o centro da cidade, a escola de ensino básico rural fechou há alguns anos e a igreja vive da insistência das pouquíssimas pessoas que frequentam o centro do bairro.

Conversamos com o casal Sr. Mauro e Sra. Vera que nos contou sobre a sua jornada de trabalho: "trabalhamos das 7 horas até as $23 \mathrm{~h} 30$, ou mais até, dependendo do tamanho da colheita que temos que fazer naquele dia, e, em tempo que não é de colheita, vai até 19 horas. A gente almoça às 11 horas, leva marmita na roça, toma café às 15 e janta por 19 horas" (Entrevista com Vera Lúcia de Almeida e Mauro Fogaça, bairro da Boa Vista, 18 jul. 2015).

Vera e o marido trabalharam na produção de tomate durante muitas décadas, até quando os filhos viviam com eles, mas deixaram de produzir há três anos. Perguntamos sobre os motivos de abandonar a produção de tomates e ela nos disse:

Ah, o tomate é uma lavoura muito cara! E nós já perdemos muito dinheiro
tendo, inclusive, que vender nosso gado para saldar dívidas. Agora a gente
trabalha com as frutas. Temos 200 pés de caqui e 100 pés de ameixa, e também
plantamos coisas pro gasto, como arroz, feijão, tomate, verduras e legumes.
(Idem)

O tamanho total da propriedade do casal é de 40 ha; a área de trabalho utilizada com a plantação e o gado é de cerca de 20 a 25 ha.

O casal vende a produção para atravessadores e também para uma quitanda. Segundo ela, cerca de $80 \%$ da renda da família vem da venda das frutas - e, no caso de uma emergência, eles vendem algumas cabeças do gado. Perguntamos sobre os mercados institucionais como PAA e Pnae, e nos disseram que é muito distante para irem em reuniões e acabam ficando sem informações sobre esses programas. 
A Sra. Vera, além de trabalhar na roça, cuidar da casa e do quintal, também cuida da mãe e da sogra que são idosas. Sobre os filhos, ela nos disse que os quatro foram embora em busca de trabalho e salário, pois a juventude quer adquirir bens de consumo e na roça não tem dinheiro todos os dias. Segundo ela, na roça o trabalho não é muito valorizado:

O trabalho do campo deveria ser mais valorizado, a gente planta e não sabe o que vai dar, pode trabalhar ano inteiro e ainda ficar devendo, e isso é ruim. Quantas vezes tem que vender uma criação para pagar a conta da lavoura! (Idem)

Perguntamos a nossa interlocutora se ela e o marido pretendiam sair de lá e ir morar na cidade, já que as coisas estavam tão difíceis na roça e a resposta foi a seguinte:

Na propriedade, ainda assim é melhor que empregado porque está investindo numa coisa que é sua. Pode não ganhar muito, mas é algo seu, e ali pra frente tem algo.

Aqui tem tudo, feijão, batata, verdura, tudo, frango, leite, ovos, nós vamos uma vez no mês na cidade só pra comprar sal pras vacas, vender feijão na feira [risos].

É melhor viver no sítio que na cidade, mas olha só para nós, lá no sertão já, a única coisa que a gente pede na prefeitura é para arrumar a estrada para a gente poder sair de lá quando precisa, a única coisa que a gente pede é isso, pois é muito longe e, quando chove, ficamos isolados aqui, sem poder sair. Como é sertão, ninguém olha por nós, e não tem nem condução, faz muita falta... então uma estrada boa e um ônibus, aí sim seria excelente para nós lá da Boa Vista. Pois um taxi fica em 75 reais, e isso não dá pra ser. (Idem)

Vera reclama da falta de investimentos na manutenção da estrada principal que liga o bairro à sede da cidade e da ausência de transporte público para se deslocar até lá - diante de tantas dificuldades, ela vai apenas uma vez por mês para a cidade. Quando ela diz "ali pra frente tem algo", ela se refere a ter um meio de vida, um lugar para onde voltar se tudo der errado, e é nisso que o casal pensa, em ter o que deixar para os filhos, caso precisem voltar. Assim como também avaliam que, por falta de terra, seus parentes levam uma vida mais difícil na cidade:

Por isso tem que manter a terra pra eles depois, pois, pra você vê, os meus pais já tiveram fazenda ali nesse lugar e já venderam porque os filhos iam casando e ninguém queria ficar por ali, por conta de ser deserto, e agora tem irmão que passa falta de ter uma terrinha pra fazer a vida, poderiam estar melhor se tivesse terra. (Idem) 


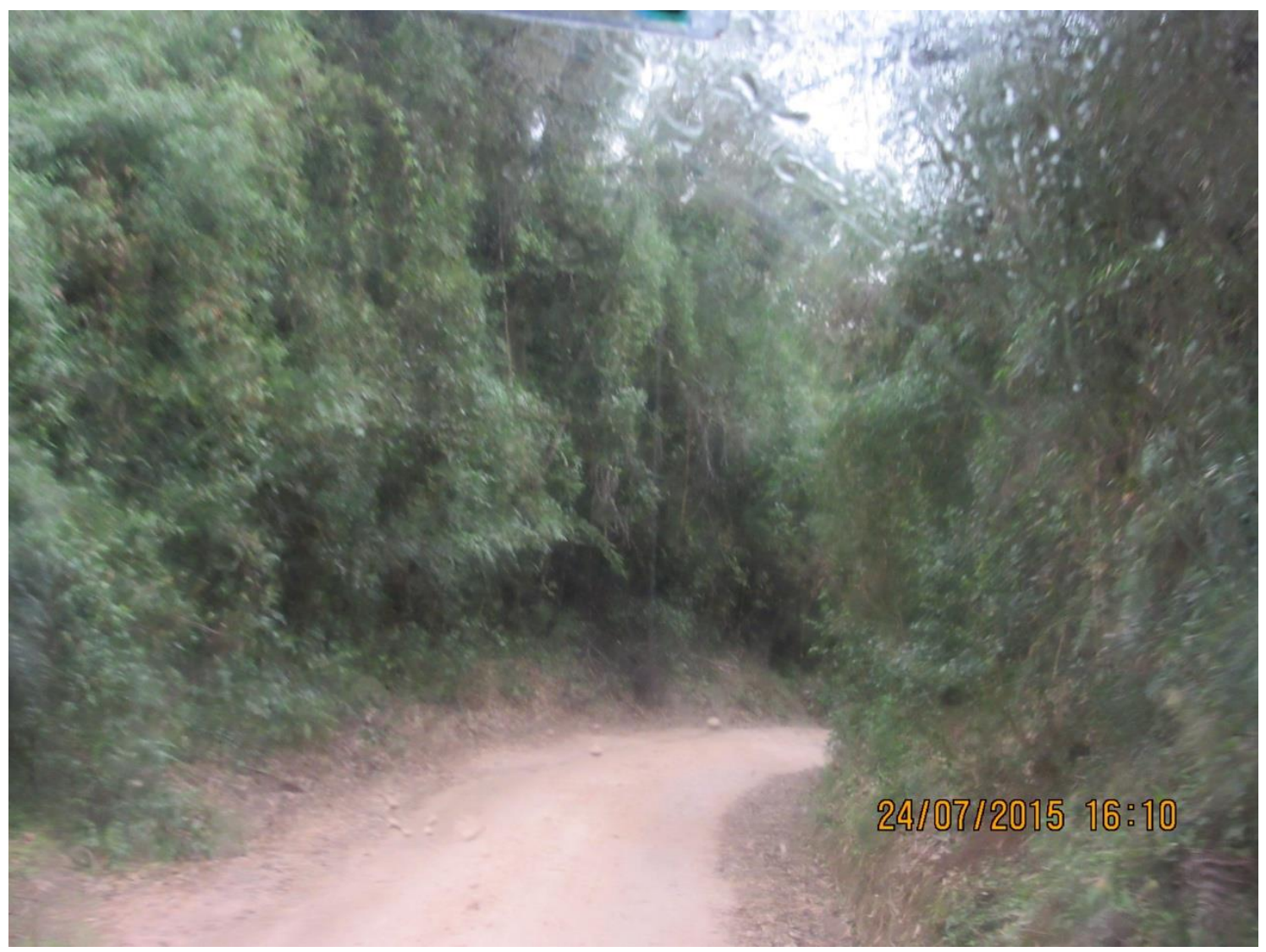

Foto 23: Estrada para o bairro da Boa Vista - floresta preservada. Foto: Lucinei Paes de Lima, jul. 2015.

A Foto 23 mostra o caminho que percorremos para chegar a esse bairro, a estrada é toda estreita e a floresta é densa. Segundo eles, nessa mata é possível encontrar uma espécie de onça. Para nossa surpresa, encontramos um tatu na volta. Na Foto 24, a plantação de caqui do casal Vera e Mauro, e a moradia, na Foto 25.

$\mathrm{Na}$ Foto 26, vemos o Sr. Mauro alimentando as galinhas. Havia um pomar de frutas no quintal ao redor da residência e uma horta com legumes e verduras. Por um instante pudemos entender a fala da Sra. Vera, quando ela diz que vai à sede do município apenas uma vez a cada mês para comprar algumas poucas coisas.

Durante o trabalho de campo, nas visitas e entrevistas realizadas, registramos algumas imagens que retratam a diversidade da produção camponesa (Foto 24 a Foto 31). 


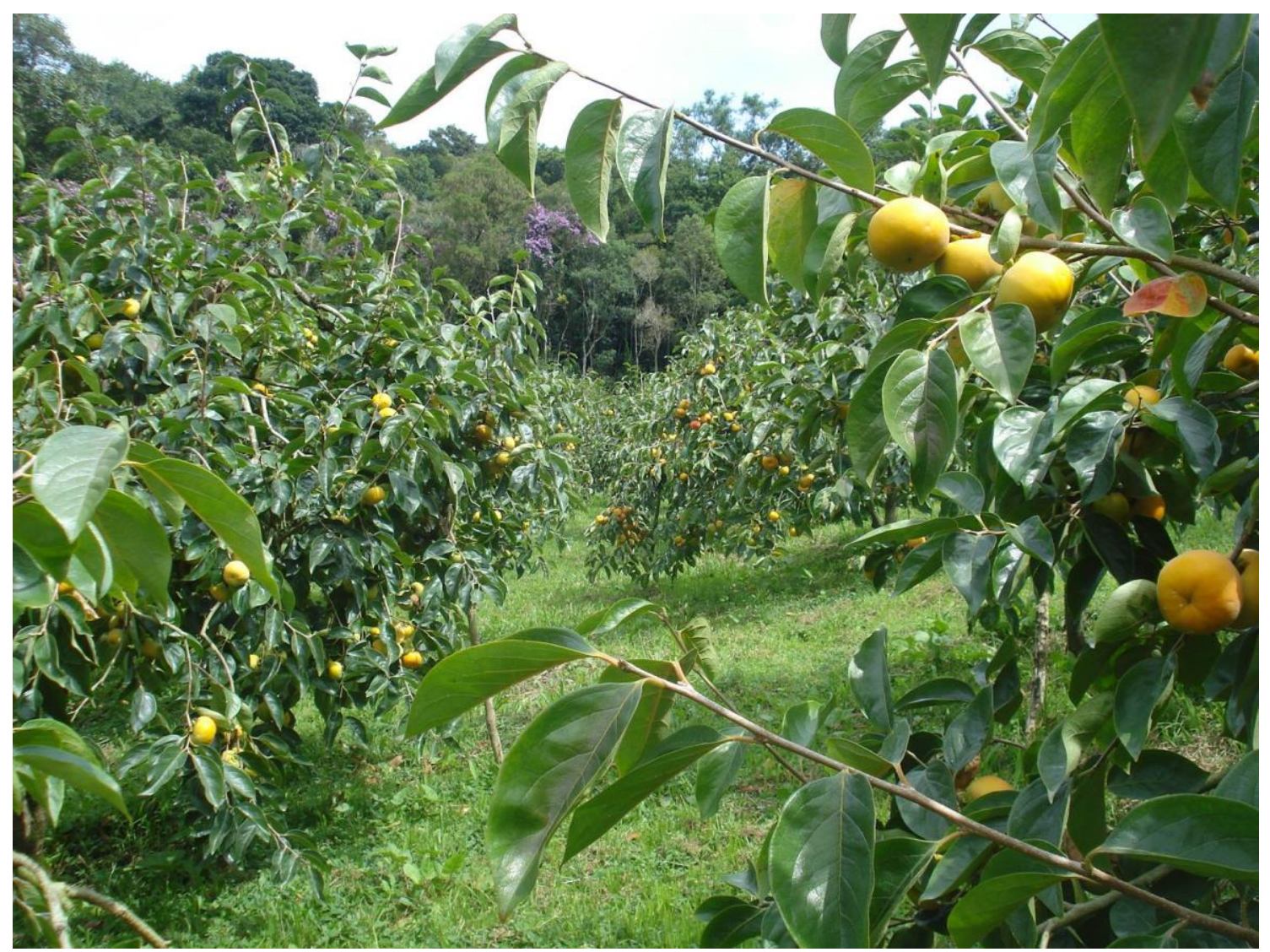

Foto 24: Produção de caqui do sítio de Vera e Mauro, bairro da Boa Vista. Foto: Sueli Almeida, abr. 2016.

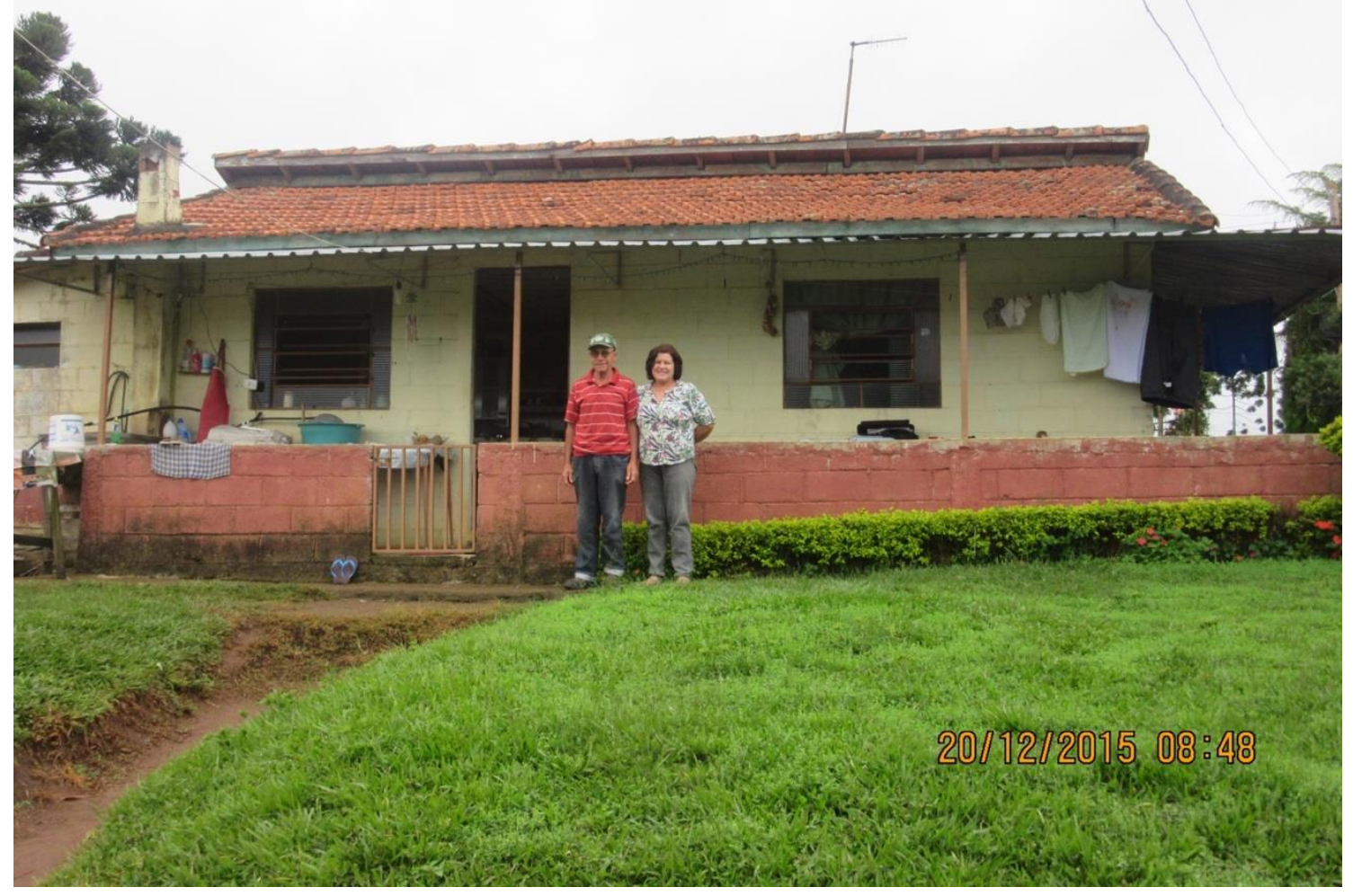

Foto 25: O casal Vera e Mauro. Foto: Lucinei Paes de Lima, dez. 2015. 


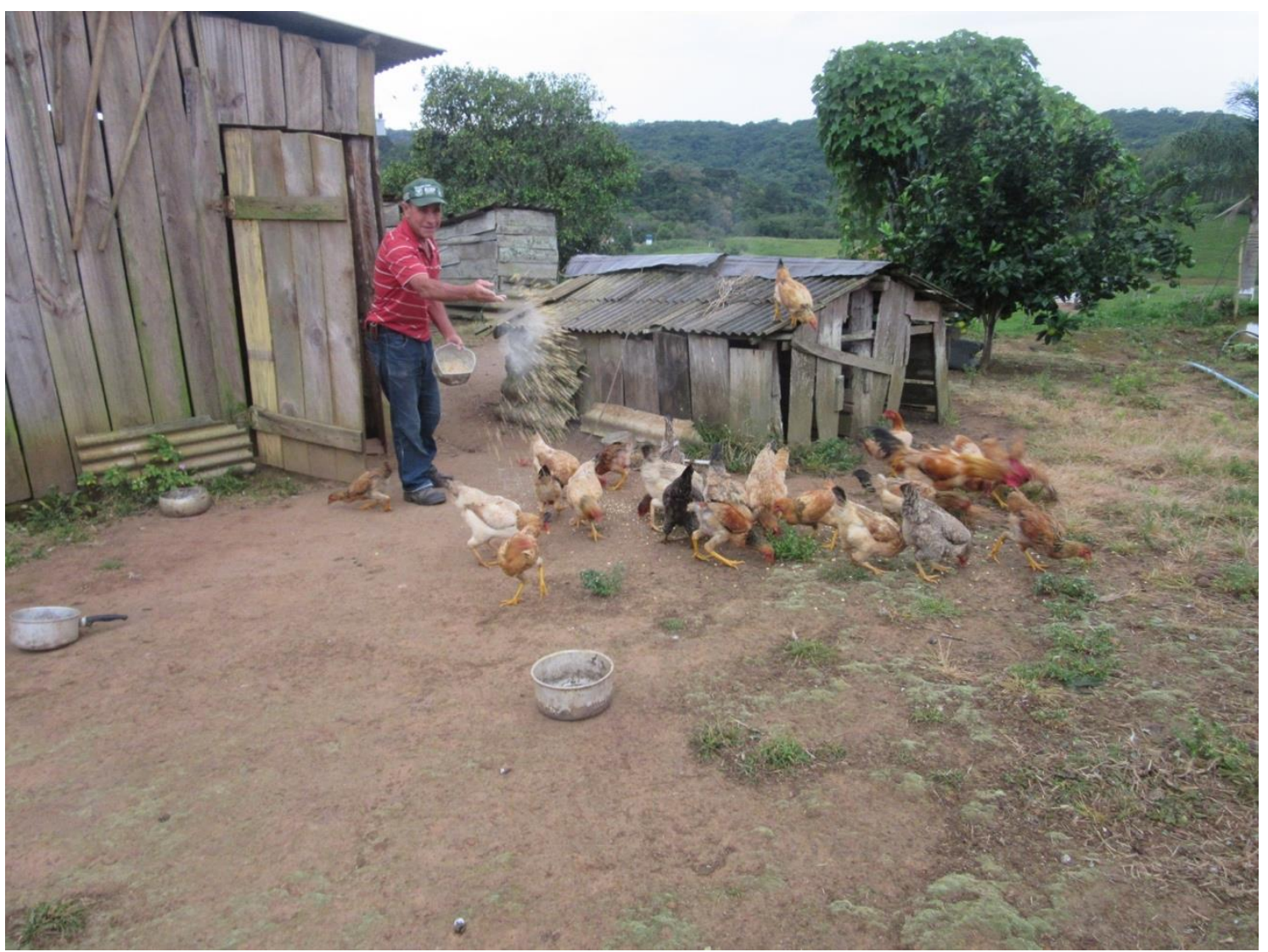

Foto 26: Mauro alimentando as galinhas. Foto: Cauã Paes, dez. 2015.

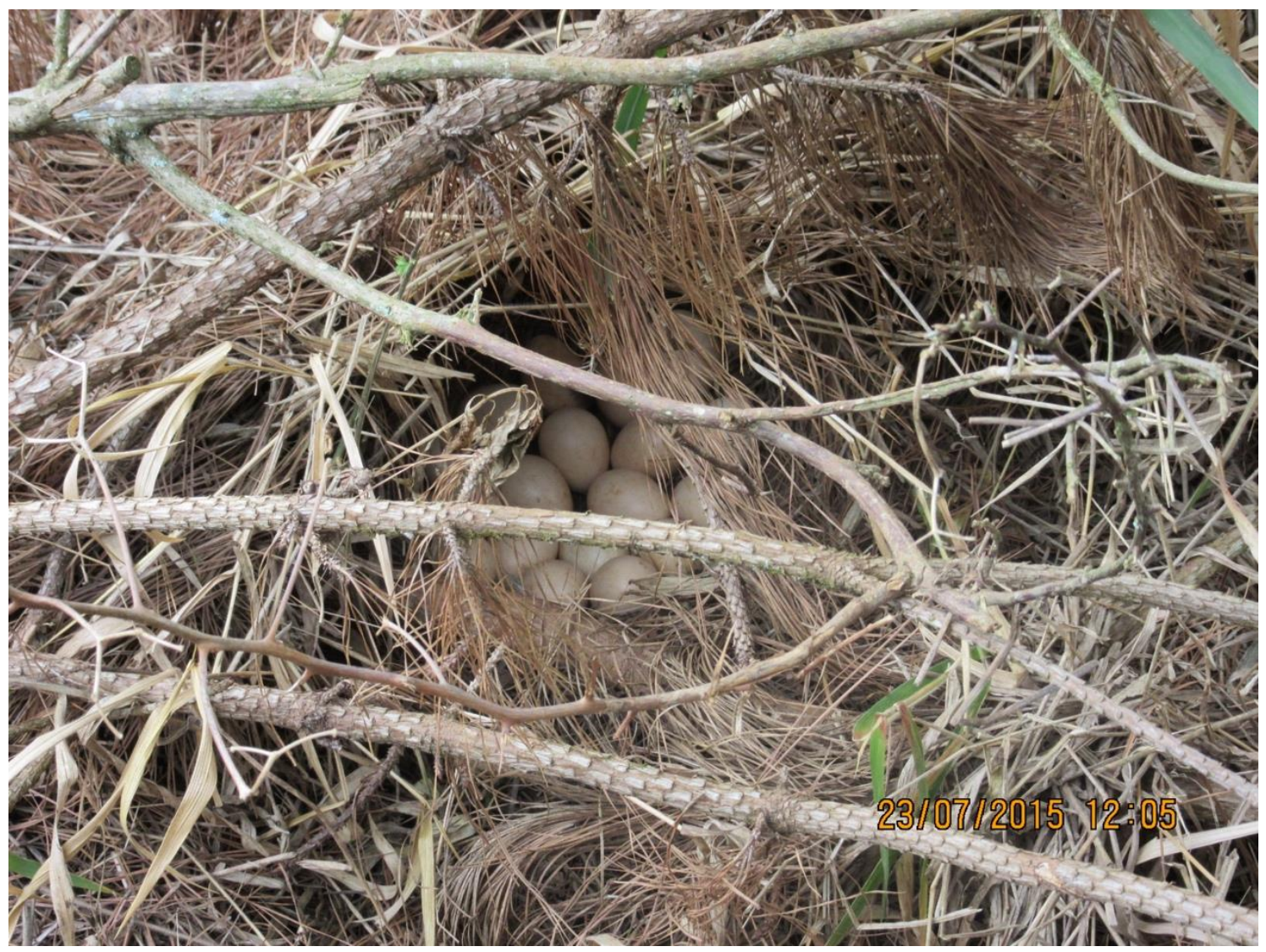

Foto 27: Ninho encontrado durante caminhada pelo sítio São Luiz, bairro do Rio Apiaí. Foto: Lucinei Paes de Lima, jul. 2015. 


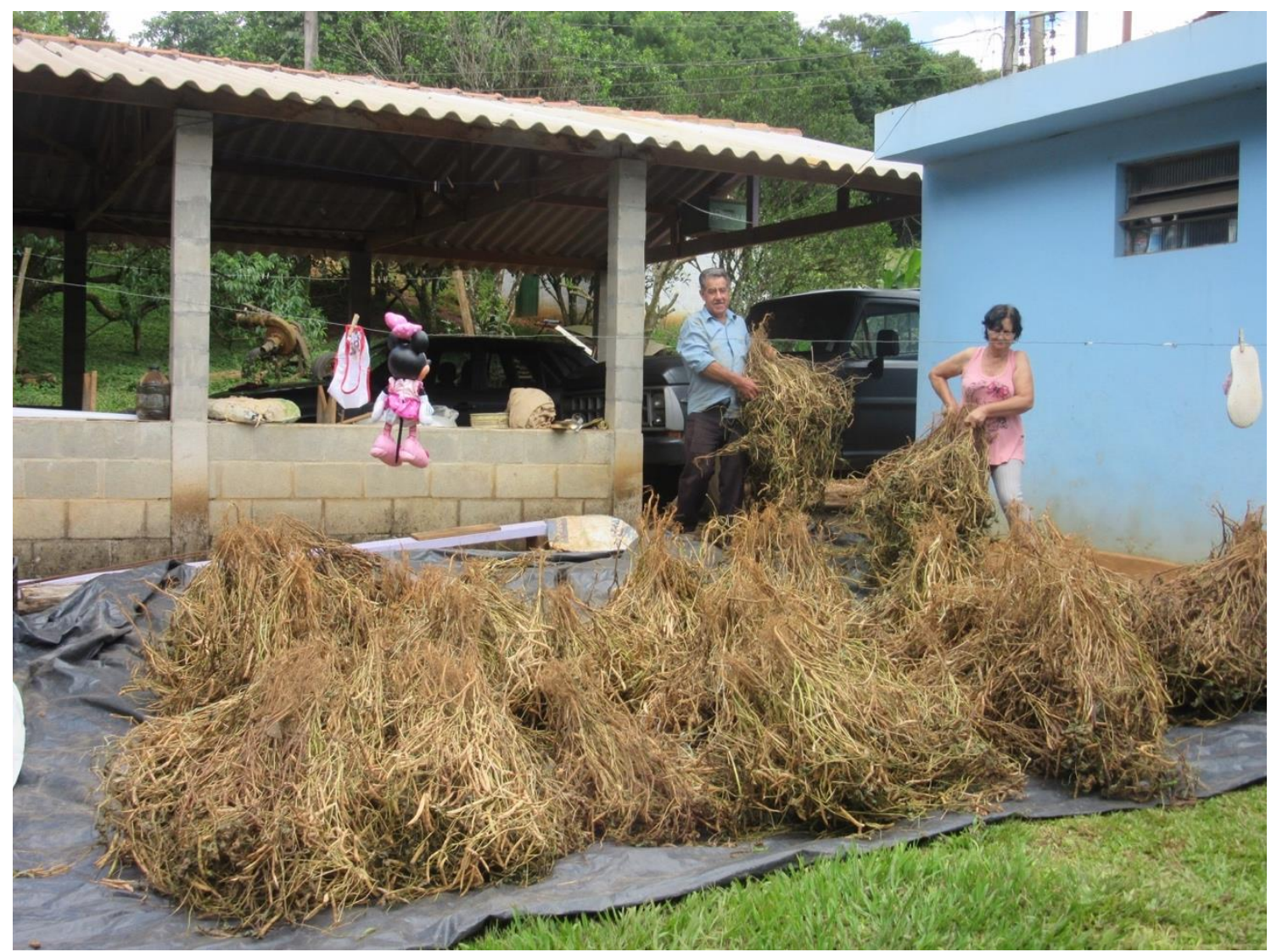

Foto 28: Secagem do feijão para consumo da família no sítio São Luiz, bairro do Rio Apiaí. Foto: Lucinei Paes de Lima, dez. 2016.

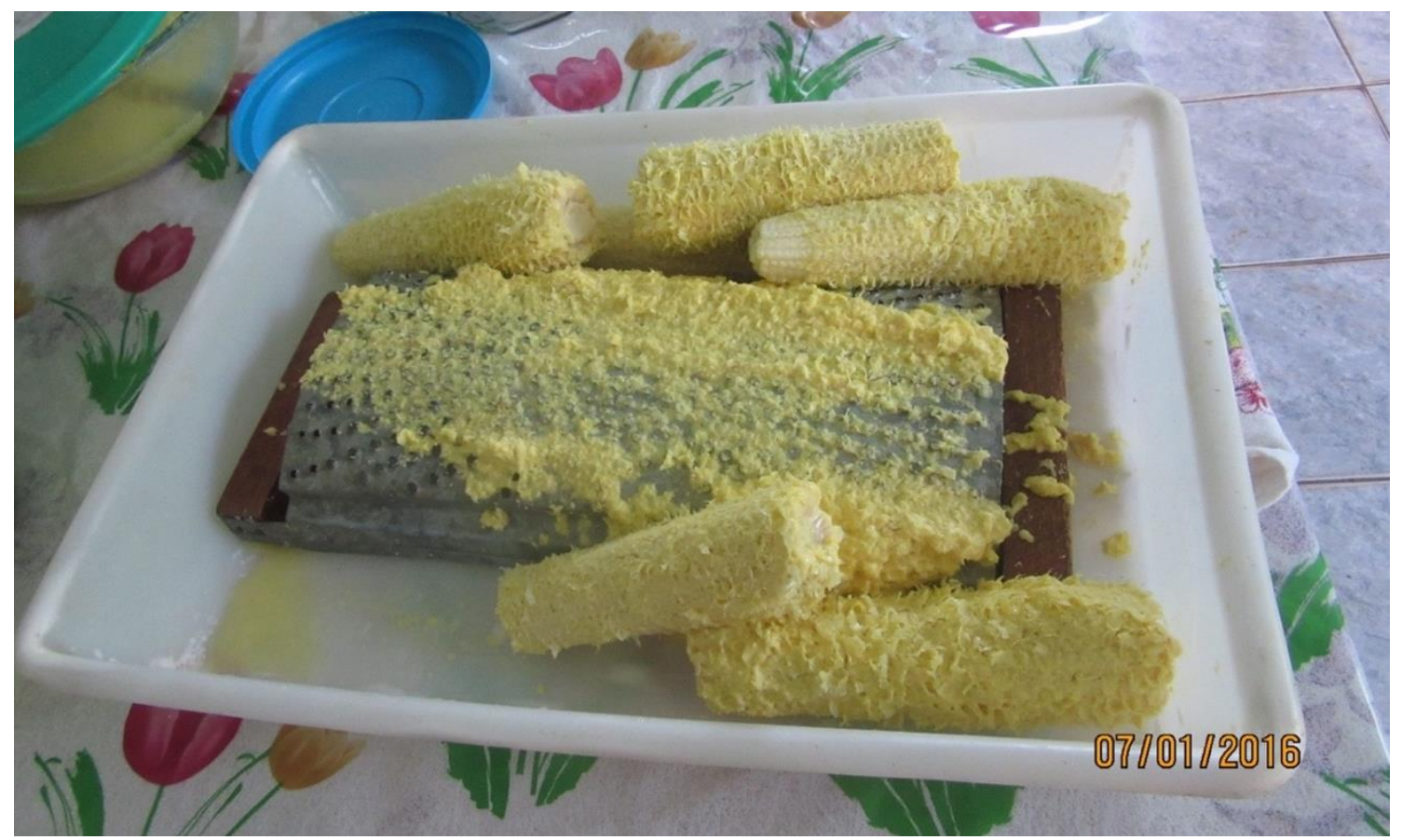

Foto 29: Milho verde sendo ralado para o almoço de mingau com frango caipira. Associação dos Produtores da Microbacia do Rio Apiaí Guaçu - Banco da Terra, bairro Coimbra.

Foto: Lucinei Paes de Lima, jan. 2016. 


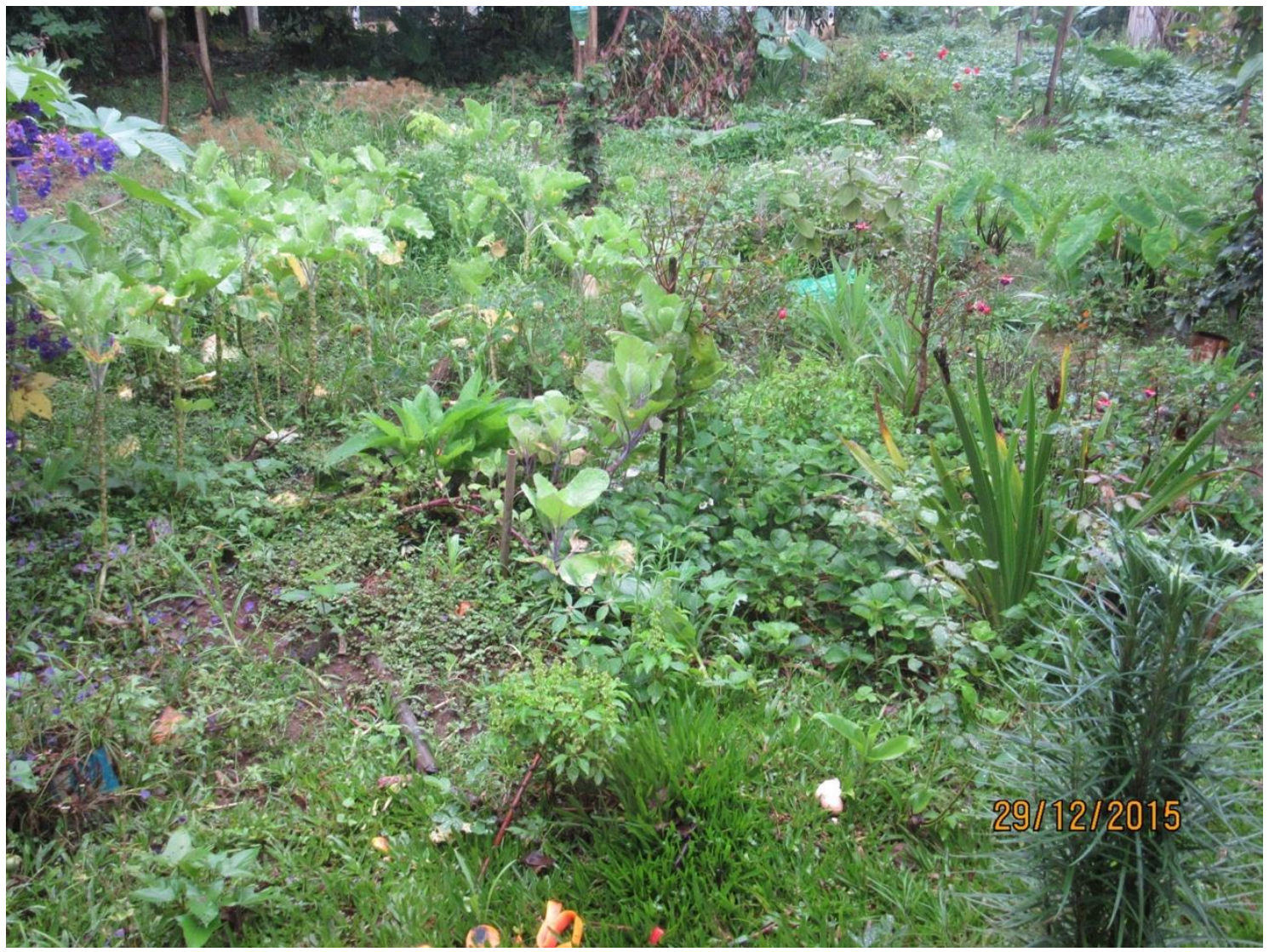

Foto 30: Horta com verduras, legumes e plantas medicinais - variedade de culturas na propriedade camponesa. Associação dos Produtores da Microbacia do Rio Apiaí Guaçu - Banco da Terra, bairro Coimbra. Foto: Lucinei Paes de Lima, dez. 2015. 


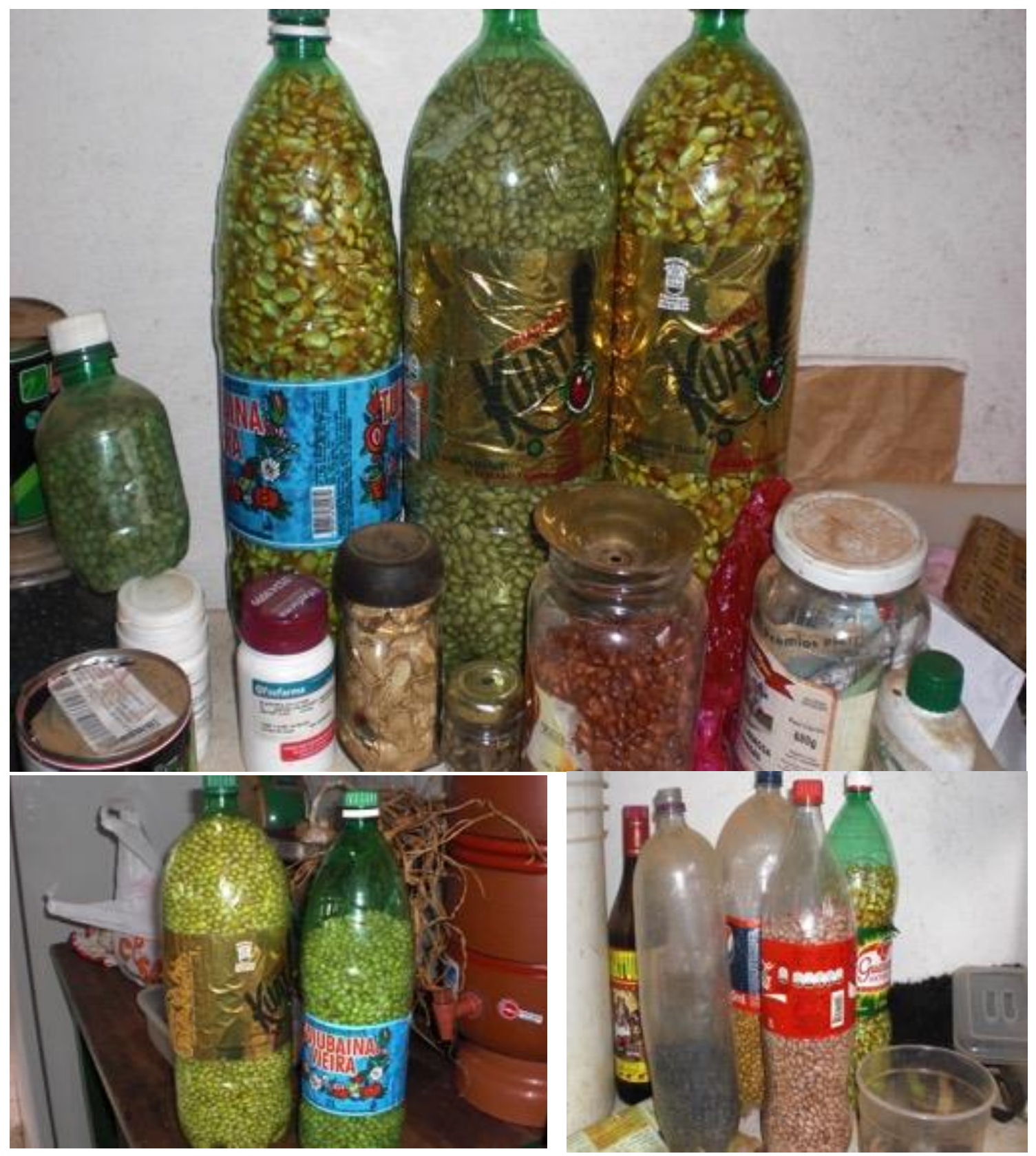

Foto 31: Cantinho das sementes já separadas para o plantio. Sítio Primavera, bairro do Rio Apiaí. Foto: Lucinei Paes de Lima, jul. 2015. 


\section{Recriação camponesa: os caminhos à terra de trabalho}

A terra possui papel central para o campesinato, é ela que garante a sua recriação. Desse modo, ocorre uma busca incessantemente pelo acesso à ela e, em Ribeirão Branco, não tem sido diferente.

Durante a nossa pesquisa, pudemos dialogar com famílias que acessaram a terra de diferentes maneiras, e vamos conhecer um pouco dessa realidade a partir dos depoimentos que coletamos.

Uma das famílias é a da Sra. Nilda que, com muitas dificuldades, conseguiu poupar dinheiro e comprar a sua terra. Ela nos contou a sua trajetória e da sua família em busca da terra.

Lucinei: Como foi a trajetória de vinda para a terra?

Nilda: Ah, nós trabalhamos de empregados no tomate a vida inteira e só agora que conseguimos a nossa terrinha.

Lucinei: Você podia falar um pouco da história, de como foi a vida de vocês até aqui?

Nilda: Então, como empregado no tomate, nós trabalhamos vinte e seis anos, desde 89. Sempre com o tomate mesmo. Teve uma época que fomos meeiros e depois viramos assalariados com carteira e tudo, aí melhorou mais, aí deu para juntar coisas e ganhar um dinheiro. Como meeiro, nunca dava nada.

Lucinei: Vocês juntaram dinheiro e compraram a terra?

Nilda: Então, depois que viramos assalariados, que conseguimos melhorar um pouquinho. A gente plantava aqui em Ribeirão Branco, depois ia no inverno plantar pra Mogi Mirim ou Minas Gerais, então todos os anos a gente mudava de lugar, a gente ia em cima de caminhão e tinha que tirar as crianças da escola, que estudavam um pouco em cada lugar. Onde tinha tomate a gente tinha que ir. Aqui era de novembro até junho e outros seis meses em Mogi. A gente ia porque não queria ficar só comendo o que tinha ganho nos seis meses. Assim a gente foi juntando dinheiro, tinha salário ano inteiro daí.

Então, como assalariado, era nós três da casa, menos a menina, e com isso fomos juntando e economizando tudo o que podia, com esse sonho de ter uma terrinha. Conseguimos até ver lá em Minas Gerais uma terrinha que dava para nós comprar, mas a gente é daqui e queria aqui mesmo, e fomos juntando todo ano o que podia.

Depois o marido deu certo de entrar como encarregado da fazenda e aí melhorou bem o salário dele, e com isso que deu para juntar mais ainda. Depois a menina também foi registrada, e chegou um momento que nós quatro da família estávamos registrados, com isso a gente guardava e foi juntando. Teve um período que vendemos até o carro pra economizar, os outros tinham e a gente não, mas o dinheiro estava sendo guardado. Foi aí que apareceu essa oportunidade aqui.

Lucinei: O que mudou na vida de vocês depois que compraram a terra?

Nilda: Olha, se eu falar que é fácil, eu tô mentindo! Porque a gente estava acostumada com um tipo de vida, todo mundo tinha um dinheirinho certo para gastar, e isso não tem mais. Então a gente tem que aprender a viver de forma diferente, mesmo já sendo da roça e sabendo trabalhar na roça, mas por ficar tanto tempo recebendo salário, a gente se acostuma com aquele jeito. 
Então, o difícil é que não tem salário agora e tem que viver do que a gente colhe, isso é meio complicado, mas a gente fez adaptações.

Mas veja bem, por outro lado, o ganho é muito grande, tudo o que ganhar é seu. Se você conseguir administrar, consegue viver bem, se não, passa aperto no seu sítio. Aqui em casa é tudo na ponta da caneta, o que vende e o que compra, anota tudo.

Então o que mudou foi isso, porque, em média de salário, a gente ganhava, todo mundo junto, uns 4 mil por mês ${ }^{19}$, então assim, aquela regalia que tinha lá de ficar comprando algumas coisas, aqui não dá, tem que se adaptar, tem que economizar.

Mas, antes, a gente plantava um pouquinho de mandioca e, quando tinha que ir pra Mogi, a gente tinha que largar tudo e ir. Agora tá aqui, olha, venha aqui fora ver tudo o que eu tenho aqui, venha ver a riqueza que nós temos aqui! Quanta coisa temos aqui! Se você planta um pé de uma fruta você vai aproveitar porque é da gente mesmo!

Não é fácil, mas é possível. Tem um problema que é crédito no banco, eles não dão pra nós! A gente vai lá e eles querem saber até o que você jantou ontem e não te dão crédito para começar a vida.

Mas, estamos muito felizes e isso é o que mais importa. Os filhos estão gostando, estão contentes. Pra você ver, o menino tem 27 anos, se ele quisesse e não gostasse, podia ir embora, mas pergunte pra ele se ele quer? A menina tem 19 e também está toda animada com as coisas dela aqui no sítio.

Lucinei: O que estão produzindo no sítio?

Nilda: Agora temos tomate, 4,5 mil pés, a vagem já está acabando, temos também outro tomate mais novo, 5 mil pés, que já está quase na hora de plantar ele na roça. A gente pensa que podia plantar uns 10 mil pés de tomate porque é o que dá retorno mais rápido pra gente, mas melhor plantar 5 mil pés e zelar bem do que plantar 10 mil e não conseguir zelar direito e dar muitas pragas e a produção ser baixa.

Lucinei: De onde vem a maior renda de vocês hoje?

Nilda: Do tomate. A gente aprendeu a trabalhar nele, conhece bem ele. Nós trabalhamos muito tempo com isso. Ontem mandamos pro Ceasa e veio fatura a 70 reais a caixa de tomate.

Lucinei: Vocês trabalhavam como assalariados do tomate, agora têm a sua terra e podem decidir e continuam trabalhando com o tomate?

Nilda: Eu acho que, tirando o salário, agora é de onde a gente pode tirar mais dinheiro. E hoje é diferente, hoje a gente vive melhor. Vive com menos dinheiro, mais feliz. Eu tô muito feliz! Nós vamos todo mundo junto pra roça, acorda junto, e é uma delícia! O sítio aqui é próximo à cidade, pras crianças irem quando quiserem. Agora temos tudo, compra quase nada. Temos ovo, frango, feijão, milho, alho, batatinha, cebola, horta, pomar, laranja, mexerica, abacate, banana, maçã, porco, gordura não compra.

Às vezes a gente tem a despesa do mês aqui e nem sabe, né? (Entrevista com Nilda, jan. 2016.)

Encontramos a família da Sra. Nilda com muitas esperanças em relação a nova vida que acabaram de iniciar, já que compraram o sítio há menos de um ano. Embora admitam a dificuldade de viver sem uma renda fixa, como estavam acostumados, o sentimento de

\footnotetext{
${ }^{19}$ Esse valor é consideravelmente alto comparado a realidade dos demais assalariados do tomate, isso porque, nos últimos anos, na fazenda onde trabalhava, o marido da Sra. Nilda assumiu o cargo de gerente da fazenda e todos os demais três membros da família também eram registrados, e recebiam um salário mínimo.
} 
felicidade é expresso quando nos falam da autonomia conquistada e da possibilidade de poderem fazer as coisas a seu modo.

Segundo a Sra. Nilda, o sítio tem ao todo 4 alqueires e, desses, eles utilizam 1,5 alqueire, e tem 1 alqueire que é de mata. Ela nos disse que quer guardar dinheiro para fazer reformas no sítio, formar pasto para ter vacas de leite, fazer queijo e pretendem também construir um lago para criação de peixes.

A família vai para a cidade cerca de duas vezes por semana, gostam de ir às festas do bairro e se divertem na cachoeira que tem no sítio. A filha da Sra. Nilda está se preparando para entrar na faculdade e escolheu o curso de pedagogia.

Se Deus quiser, eu nunca mais quero voltar a ser empregado. A liberdade de fazer o que você acha que dá certo, você faz; não tem ninguém para mandar em você; a família está mais unida, tudo junto. Vai pra cidade hora que quer. (Idem)

A família da Sra. Nilda é um dos poucos casos de camponeses que conseguiram acessar a terra através da compra. Porém, eles admitem que, diante dos preços exorbitantes das terras, fica quase impossível um camponês pobre conseguir adquirir a sua própria terra. Citaram inclusive que, se o marido não tivesse, por um tempo, assumido o cargo de gerente, não teria sido possível acumular o que conseguiram até o momento da compra da propriedade.

Assim como a família da Sra. Nilda, visitamos outra família que também deixou para trás a vida de assalariados para viver como camponeses. Conversamos com o Sr. Nilson, que nos contou que deixou a capital paulista depois de viver ali durante trinta anos e, desde 2003, vive com a esposa, Sra. Iraci, no sítio do casal. Ele nos disse que, embora já tivesse morado na roça, a mudança nem sempre é fácil. Para a sua esposa, foi ainda mais difícil, pois, segundo ele, não ter vizinhos por perto faz com que ela se sinta muito sozinha. Além disso, tem muito trabalho. Mas, ainda assim, ele afirma que a mudança teria valido a pena e que o fato de não ter um horário fixo para exercer o trabalho é sinônimo de liberdade. 


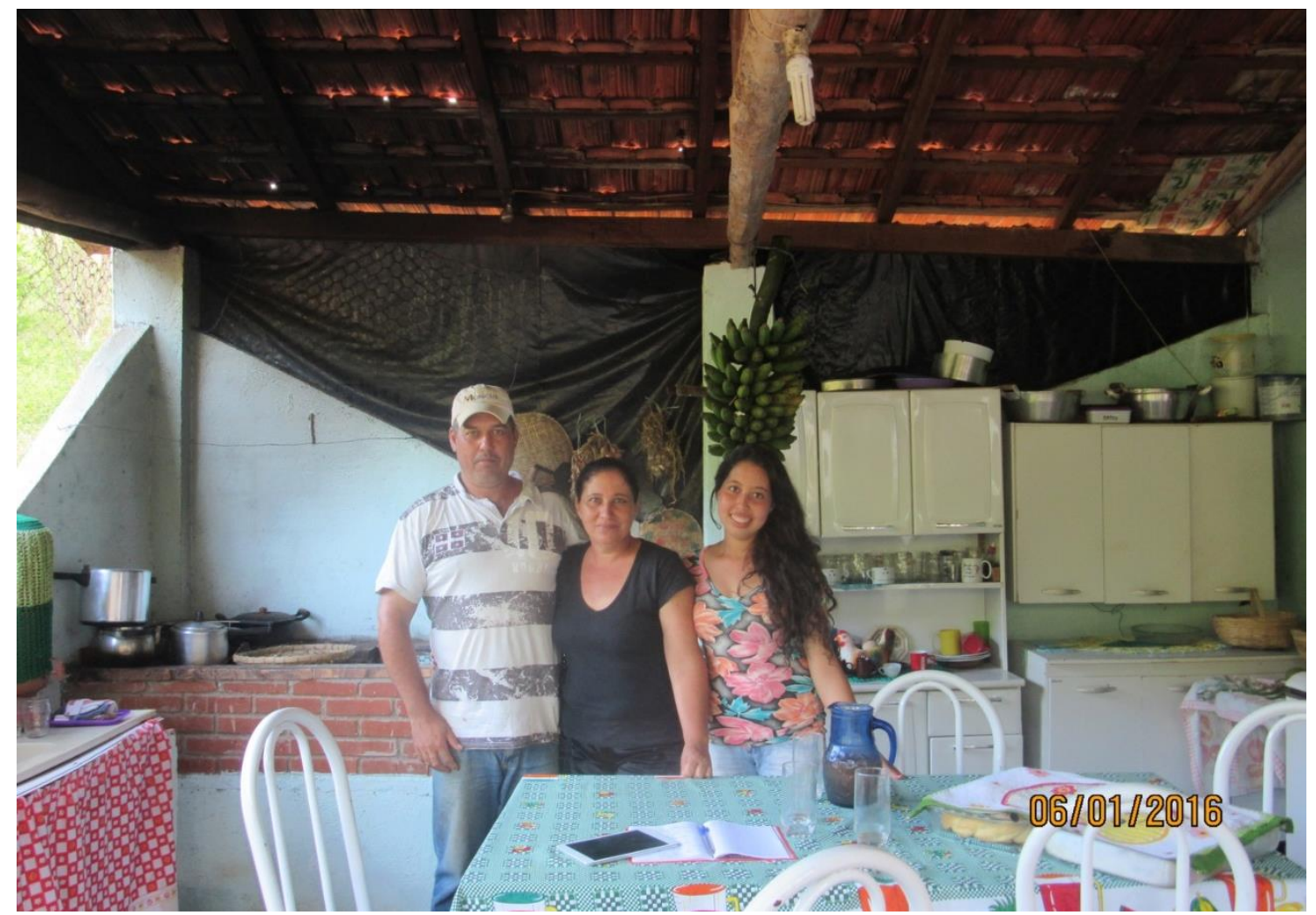

Foto 32: Sra. Nilda, marido e filha (o filho estava na roça): vida nova com a aquisição da propriedade. Bairro da Serra Velha. Foto: Lucinei Paes de Lima, jan. 2016.

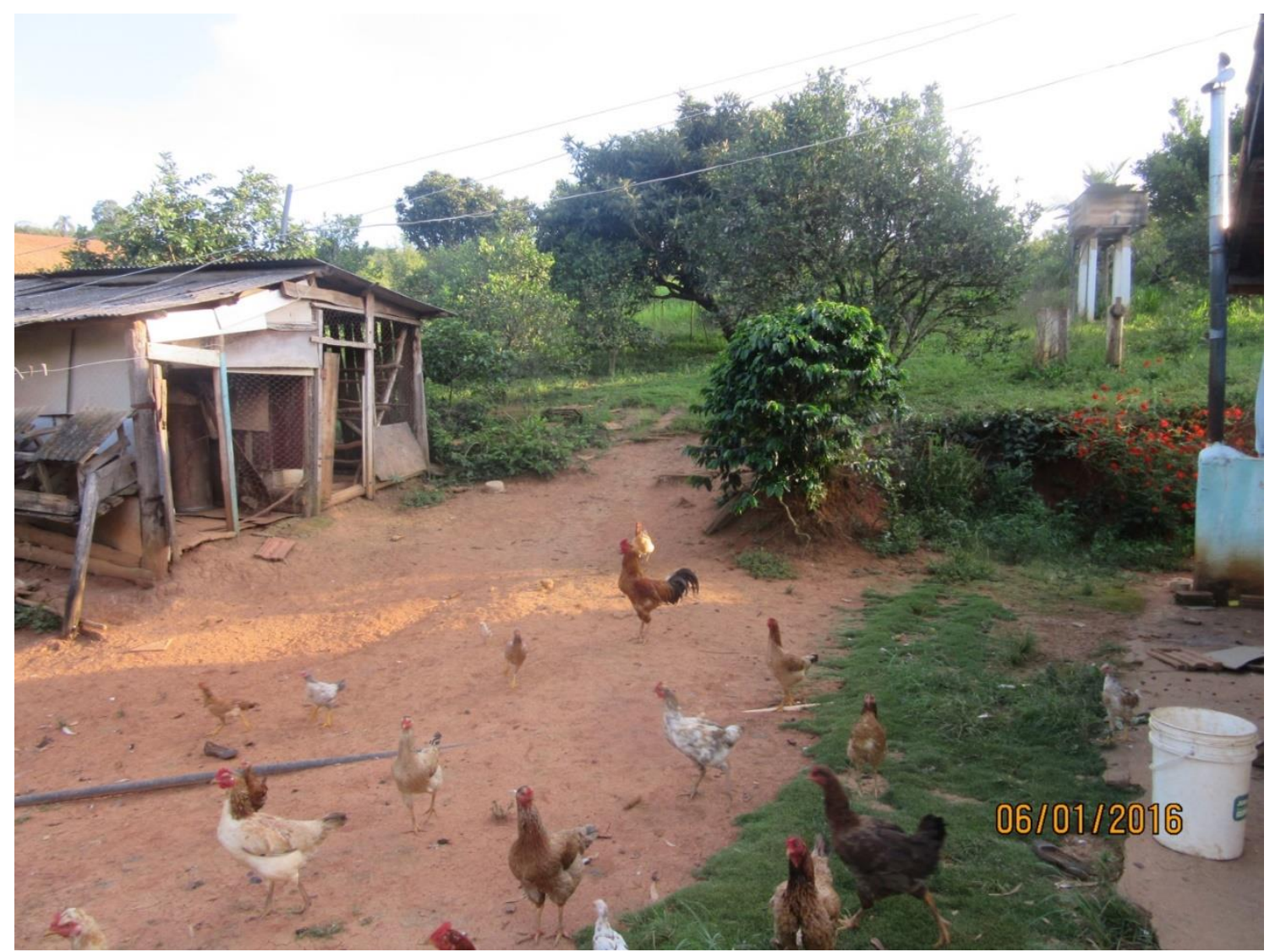

Foto 33: Propriedade da família da Sra. Nilda: diversificação camponesa. Bairro da Serra Velha. Foto: Lucinei Paes de Lima, jan. 2016. 
Quem nunca viveu na roça tem dificuldades de se acostumar. Aqui a gente é livre, mas, sendo livre, nunca tem parada, porque no sítio o serviço não tem fim, tem sempre alguma coisa por fazer. Na cidade, você é controlado pelo horário do relógio, aqui é o serviço que controla a gente, mas esse controle é a gente mesmo que se põe. (Entrevista com Nilson, bairro da Serra Velha, 14 jul. 2015)

O Sr. Nilson nos relatou que o período em que viveu na cidade de São Paulo foi sempre pensando em ganhar dinheiro para um dia comprar a sua terra. Para ele, morar e trabalhar na capital paulista foi uma aventura no início da sua vida de casado, mas o seu desejo sempre foi o de ter a sua propriedade e, dessa forma, ter uma vida mais sossegada, sem a inquietação da cidade grande.

Perguntamos sobre a renda do casal na propriedade e ele nos disse que não é possível saber exatamente, mas afirma que, nos períodos de entressafra (o de maior preocupação por ser inverno e não ter produção para vender), eles procuram reduzir as despesas e não ultrapassar os 300 reais mensais.

Ainda assim, segundo ele, a vida é melhor hoje no campo do que quando viviam em São Paulo, como pode ser visto neste trecho da entrevista:

Lucinei: Como é a rotina de trabalho de vocês?

Nilson: Aqui não temos hora pra trabalhar, mas, pra fazer uma média, trabalhamos cerca de 8 a 9 horas no período da safra. Já no inverno é mais devagar, umas 3 horas por dia. Pra você ter uma ideia, quando é tempo do tomate, vai até umas 10 horas por dia às vezes. Nós acorda pelas 6 horas, e aqui a gente tem um costume que trouxe da cidade, a gente só toma café da manhã e almoço, e então não toma café da tarde como o pessoal daqui faz. Então não damos aquela pausa às três da tarde, e aí volta pra casa umas 19 horas. (Idem)

A família do Sr. Nilson produz tomate, maxixe, pimentão, abobrinha, ervilha, feijão e outras verduras e legumes para o consumo em uma propriedade com 24 ha. A maior parte da produção e da renda do casal, cerca de $80 \%$, é advinda do tomate. Como não ocupam toda a área da propriedade, costumam arrendar parte da área ociosa para os vizinhos que não têm terra, complementando, dessa forma, a renda da família. Abaixo, mais um trecho da entrevista:

Lucinei: De onde vem a maior parte da renda de vocês?

Nilson: A gente vende uma parte no PAA e outra para um atravessador que é dono da barraca Guaraçaí. Pra ele, vai a maior parte da produção, cerca de $60 \%$, contra $40 \%$ que vai pro PAA. O atravessador Guaraçaí paga nós de oito em oito dias; agora, só vendemos para ele porque já levamos muito calote. $\mathrm{O}$ PAA tem o preço melhor, mas demora muito a pagar, cerca de noventa dias para pagarem nós. Isso é um problema porque o tomate fica meio caro pra produzir, acho que de $100 \%$, dá uns $60 \%$ de despesa para produzir tomate. Por isso nós plantamos pouco, só 5 mil pés, só, no ano.

Lucinei: Como foi estar de volta e viver da terra depois de tantos anos na cidade? 
Nilson: A melhor coisa foi voltar na roça, acho que desde que saí da roça, acho que nunca saiu isso da minha cabeça. Então foi isso que persegui, eu não aguentava mais São Paulo. Moramos trinta anos naquele barulho e eu só pensava nisso aqui. Pra mim é o paraíso! Aquilo lá para mim é morte. Vai matando a gente. Aqui sim... é a vida.

Na cidade, se você colocar o pé do lado de fora da casa está comprando algo, tem que consumir. Aqui a gente tem tudo o que precisa, só compramos açúcar, sal, óleo e enlatados, o resto tem tudo aqui.

Para mim, vir pra roça de novo é minha felicidade, eu sou mais feliz aqui. Eu quero ficar pra sempre aqui, só quando Deus me levar eu saio daqui. (Idem)

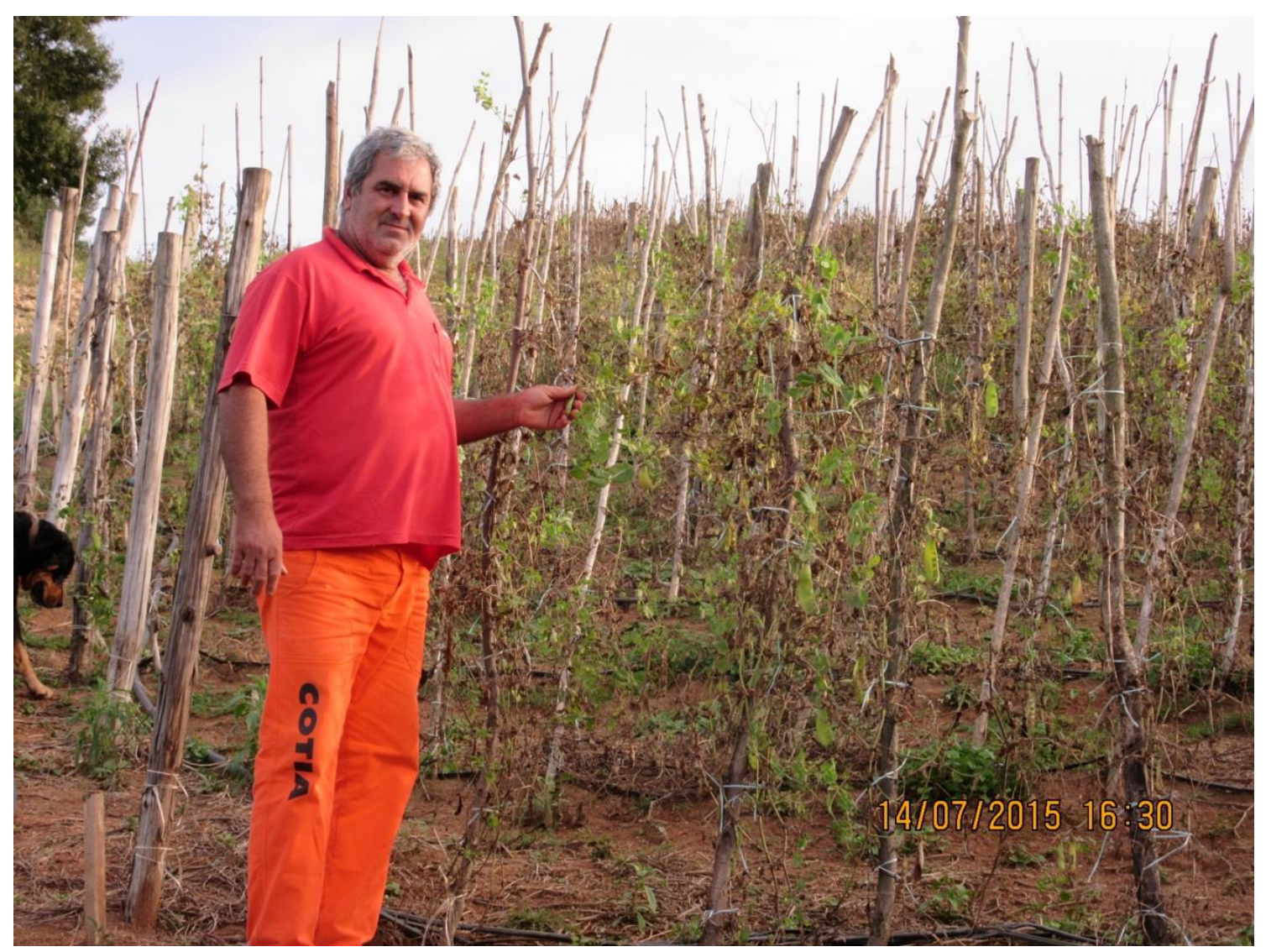

Foto 34: Sr. Nilson, em período de entressafra, na sua roça de ervilha quase finalizada. Foto: Lucinei Paes de Lima, jul. 2015.

Assim como a família da Sra. Nilda, o Sr. Nilson também se referiu a uma vida melhor no campo, na medida em que os horários e a jornada de trabalho seguem uma lógica diferente daquela do relógio. Ouvimos de vários camponeses que eles não levam relógio para a roça e que, “quando dá fome”, é só olhar para o céu e perceber (num dia ensolarado) que o sol está bem no meio dele e, portanto, já é meio-dia. Utilizam a mesma técnica para o café da tarde, que é tomado às 15 horas e também para o horário de irem para a casa, normalmente definido pelo pôr do sol. Além disso, consideram outros aspectos, como se estão muito cansados, se o serviço ainda vai demorar, se não é melhor ir embora e deixar o resto do trabalho para outro dia ou se, 
ao contrário, o serviço está próximo do fim e, então, é melhor aguentar mais um pouco e descansar mais no dia seguinte.

Durante a nossa pesquisa de campo dialogamos com camponeses que viviam nas “associações” do Banco da Terra e do crédito fundiário (PNCF), e buscamos compreender essa realidade.

A Lei complementar n. 93, de 4 de fevereiro de 1998, instituiu o Fundo de Terras e da Reforma Agrária, ou Banco da Terra. Segundo Camargo (2005), o projeto foi criado com o objetivo de priorizar trabalhadores rurais não proprietários e com, no mínimo, cinco anos de experiência na atividade rural. Os proponentes também deveriam possuir $80 \%$ da renda bruta familiar provinda de atividades agropecuárias e não ter restrições cadastrais junto ao agente financeiro.

Ficavam impedidos de participar do programa os candidatos que tivessem participado de alguma ocupação ilegal de terra, bem como os que já tivessem sido contemplados por um projeto de assentamento rural. Também não poderiam receber recursos funcionários públicos e trabalhadores rurais que dispusessem de uma renda familiar bruta superior a 15 mil reais anuais. Após receber o financiamento, o beneficiário teria até 20 anos para saldar sua dívida, incluídos três anos de carência, com juros que variavam de 6 a $10 \%$ ao ano. Os agricultores que pagassem em dia suas prestações teriam o direito a rebates (descontos que incidem sobre os juros), sendo que seriam dados 50\% de rebate aos financiamentos em regiões tidas como mais pobres (como o Nordeste, por exemplo) e $30 \%$ nas demais regiões.

Por meio deste crédito foram distribuídos, em seus quatro anos de aplicação, cerca de 955 milhões de reais para quase 55 mil famílias em todo o Brasil. (CAMARGO, 2005, p. 4)

O que ouvimos sobre o programa Banco da Terra em Ribeirão Branco foram extensos relatos sobre as irregularidades na sua implementação, que vão desde a inflação do mercado de terras até o favorecimento político e financeiro por onde ele foi implantado. Nos disseram que as famílias foram abandonadas à própria sorte e com uma dívida a ser paga sem qualquer tipo de assistência.

Paulino, sobre o programa Banco da Terra, afirma que:

A inadimplência começa a rondar os primeiros projetos já no vencimento da primeira parcela e isso tende a inviabilizá-los como um todo, senão vejamos: por pressupor aval solidário, cada um dos comtemplados é responsabilizado pela dívida global do projeto. (PAULINO, 2012, p. 322)

Deixemos que Paulino discorra mais sobre o Banco da Terra:

Além de premiar a especulação, esse mecanismo faz com que os preços da terra subam proporcionalmente ao aumento da demanda. Trata-se, enfim, da conversão da renda fundiária em renda capitalizada às expensas do dinheiro público. 
Nos municípios onde se implantou esse projeto, os técnicos foram unânimes em afirmar que a simples notícia de que há crédito disponível para tal implica o imediato aumento do preço da terra. Foram comuns os relatos de que os fazendeiros se uniram em torno da elevação artificial dos preços diante da formalização dos grupos para se beneficiarem do programa. Talvez seja até necessário acentuar quais os reflexos no mercado fundiário da região, tendo em vista que talvez ninguém, além do Estado, se disporia a comprar grandes propriedades à vista, ao preço estabelecido pelos primeiros. (PAULINO, 2012, p. 316)

Realidade parecida com a tratada pela autora nos foi relatada pelos camponeses que residem nas associações que visitamos. Vale dizer que, só no município de Ribeirão Branco, são quatro associações do Banco da Terra e, até o momento da nossa pesquisa, estavam oficializadas duas associações do novo programa, o Programa Nacional de Crédito Fundiário (PNCF). Visitamos duas do Banco da Terra e uma do PNCF.

Na Figura 15, elaborada pelo engenheiro agrônomo Francisco Feitosa (técnico do Instituto de Terras do Estado de São Paulo - Itesp, e responsável por atualizar e assessorar essas associações), podemos verificar o número de famílias que acessaram o Banco da Terra e o Crédito Fundiário no estado de São Paulo. Ribeirão Branco está no grupo de cor verde e é o $13^{\circ}$ município da lista, com 58 famílias no Programa Banco da Terra e 15 famílias no Crédito Fundiário.

Procuramos o Sindicato de Trabalhadores Rurais, que tem um trabalho de acompanhamento dessas famílias. Segundo o diretor do sindicato, Sr. José Vicente, a maioria das famílias atualmente no Programa não são aquelas que estavam desde o início. Pois, diante das incertezas do Programa e também por não terem condições de pagar as primeiras parcelas da dívida adquirida, a maioria das famílias acaba indo embora. Com isso, fazendeiros da região começaram a invadir essas terras para produzir tomates.

A partir dessa situação, segundo o Sr. José Vicente, camponeses indignados procuraram o sindicato, que começou a reunir famílias, e decidiram ocupar as terras invadidas e lutar para rechaçar os fazendeiros. Isso também foi relatado por um dos moradores da Associação dos Produtores da Microbacia do Rio Apiaí Guaçu - Banco da Terra, no bairro Coimbra: "Se nós não entra aqui, os fazendeiros estavam aqui dentro, plantando aqui! Então viemos, e foi nos quatro Banco da Terra do município que fizemos isso!” (Entrevista com Luiz Gonzaga, 15 jul. 2015). 


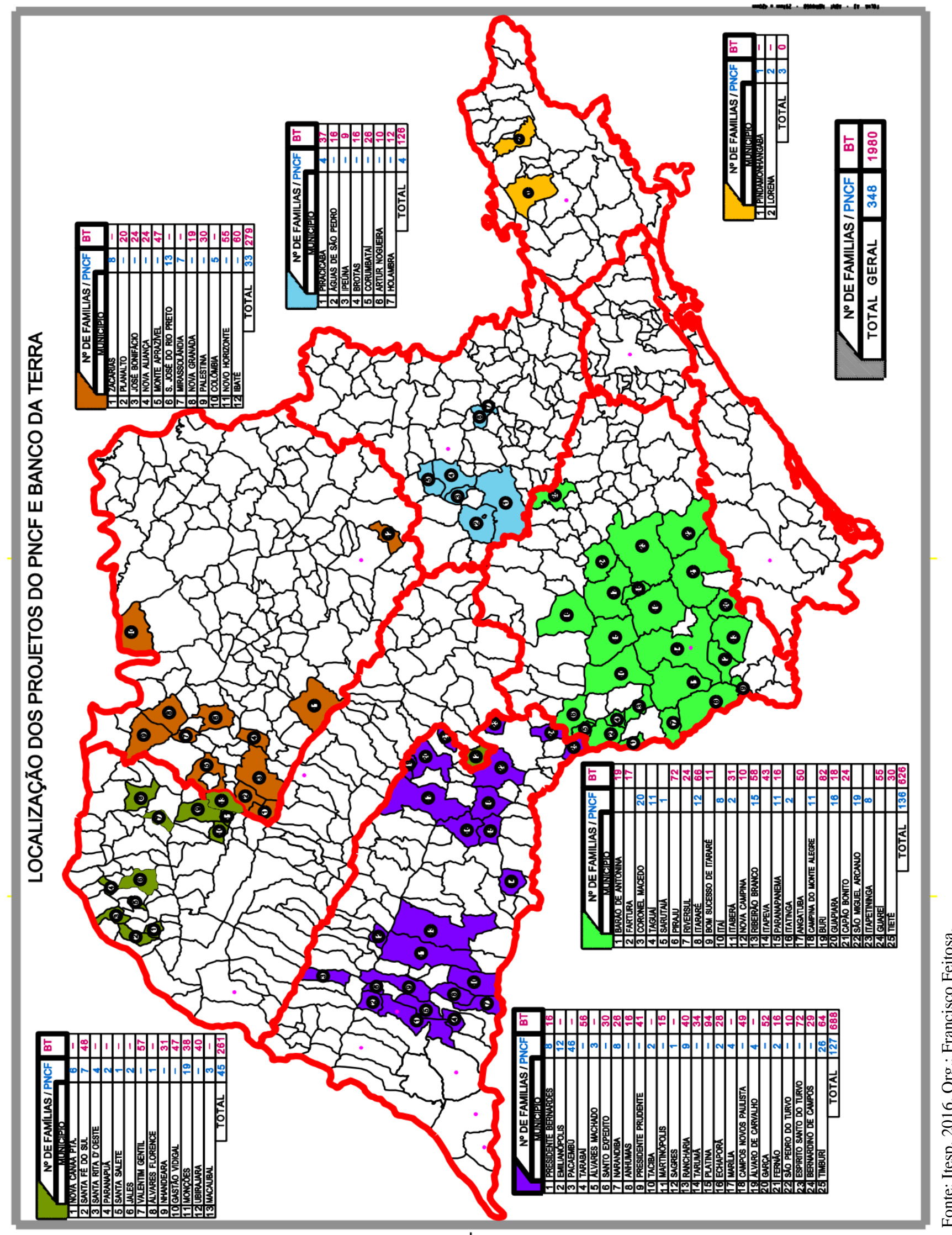

Figura 15: Número de famílias residentes nos projetos do Banco da Terra e do Crédito Fundiário no estado de São Paulo. 
Vale dizer que os próprios moradores dessas associações, ao serem perguntados, afirmam que residem em associações do Banco da Terra de determinado lugar. Foi-nos dito que todas as associações do Banco da Terra do município, e também da região do Sudoeste paulista, estão inadimplentes e as famílias estão com dificuldades para realizar um acordo que consigam pagar. De acordo com o dirigente sindical, José Vicente, essa realidade também é encontrada nos outros estados onde foi implantado o projeto. Essa situação também é parecida com a encontrada por Paulino:

Um dos problemas do Bando da Terra é a necessidade de se pagar pela terra um valor de mercado, na melhor das hipóteses, acrescido de juros e correção monetária. Enquanto não vencerem as parcelas, quaisquer problemas serão contornados. Diríamos mais, com a carência, é possível que a grande maioria não tenha dificuldade em saldar os primeiros débitos, pois terão mais tempo para poupar. Na sequência, ficarão na dependência estrita do ano agrícola para extrair renda suficiente para sobreviverem e ainda saldá-las. (PAULINO, 2012, p. 323-324)

Vale dizer que o programa Banco da Terra foi substituído pelo Programa Nacional de Crédito Fundiário e, conforme nos explica Borges (2016), consultor do Ministério do Desenvolvimento Agrário na Secretaria de Reordenamento Agrário, passou a ser tratado de acordo com novas normativas:

O Programa Nacional de Crédito Fundiário é uma política pública de desenvolvimento rural e combate à pobreza no campo que tem como objetivo promover o acesso à terra para agricultores familiares que não possuem ou que tenham pouca terra.

O PNCF foi criado em 2002, em substituição aos extintos programas Cédula da Terra e Banco da Terra, mas apenas em 2003 foi implementado com os princípios e diretrizes que tem hoje. O programa prioriza a aquisição de propriedades abaixo de 15 módulos fiscais, a aquisição acima de 15 módulos só é permitida com a declaração expressa do Incra [Instituto Nacional de Colonização e Reforma Agrária] informando que o imóvel é produtivo, portanto não passível de desapropriação.

Nestes quase 13 anos de execução, o PNCF já beneficiou aproximadamente 135.000 famílias em 21 estados da federação, 3,7 bilhões de reais foram investidos na aquisição de terras e 500 milhões de reais nos investimentos comunitários não reembolsáveis.

O programa é executado de forma descentralizada contando com a participação de diversos atores. A gestão é realizada pelo Departamento de Crédito Fundiário - DCF localizado na Secretaria de Reordenamento Agrário - SRA do MDA [Ministério do Desenvolvimento Agrário]. Nos estados, a execução é de responsabilidade dos governos estaduais, que criam e mantêm as Unidades Técnicas Estaduais - UTEs. A mobilização dos potenciais beneficiários bem como a qualificação das propostas de financiamento fica a cargo dos Movimentos Sociais de Trabalhadores Rurais e da Agricultura Familiar (sindicatos, federações e entidades ligados aos sistemas Contag, Fetraf e PJR). (BORGES, 2016) 
De acordo com Borges, o programa tem aumentado o número de contratações em todos os estados, e a demanda é maior entre os mais jovens, de 18 a 39 anos. Segundo ele, entre as principais razões da procura pelos mais jovens está o desejo de conquistar autonomia perante os pais e também de contrair matrimônio e iniciar uma vida a dois. Ainda, segundo Borges, atualmente o acesso ao PNCF pode ser realizado por três linhas, com condições de financiamento e critérios de elegibilidade distintos, conforme descrição abaixo:

- Linha Combate à Pobreza Rural - CPR: Para agricultores familiares que se encontram em situação de pobreza rural, que possuem renda anual familiar até $\mathrm{R} \$ 9.000,00$ e patrimônio de no máximo $\mathrm{R} \$ 15.000,00$. O prazo de financiamento é de 20 anos com carência de 36 meses e juros de $5 \%$ ao ano. - Linha Nossa Primeira Terra - NPT: Específica para jovens rurais com idade entre 18 e 29 anos. A renda familiar anual não pode passar dos R\$ $30.000,00$ e o patrimônio deve ser inferior a $\mathrm{R} \$ 60.000,00$. O prazo de financiamento é de 20 anos com carência de 36 meses e juros de $1 \%$ ao ano. Para acesso à linha NPT, o jovem deve atender a pelo menos [a] um dos critérios estabelecidos no Manual de Crédito Rural - MCR.

- Linha Consolidação da Agricultura Familiar - CAF: Para agricultores familiares sem ou com pouca terra que não estão na condição de pobreza rural, que possuam renda familiar anual de até $\mathrm{R} \$ 30.000,00$ e o valor do patrimônio não exceda $\mathrm{R} \$ 60.000,00$.

Em todas as linhas é concedido um desconto nas parcelas pagas dentro do prazo de vencimento, denominado Bônus de Adimplência. $O$ valor deste bônus varia de acordo com a região que a Unidade Produtiva está inserida.

Além do Bônus fixo de adimplência, caso o beneficiário tenha negociado o imóvel abaixo do preço médio de mercado, estabelecido pelo SMMT ou determinado pela equipe de vistoria prévia da UTE, o programa concede um bônus adicional de $10 \%$ em todas as linhas, independente da região onde o imóvel está localizado. (BORGES, 2016, p. 7-9)

Essas informações nos esclarecem sobre as linhas de financiamento e sobre a execução do Programa Nacional de Crédito Fundiário. Vejamos a seguir a realidade dos camponeses que tivemos a oportunidade de visitar e que vivem nesses projetos do Banco da Terra e do Crédito Fundiário.

Conversamos com o casal Luiz Gonzaga e Zeneide, perguntamos sobre escolaridade, filhos e como é atualmente a jornada de trabalho do casal. O Sr. Luiz nos disse que frequentou a escola até o terceiro ano e a Sra. Zeneide, até o quarto ano do ensino básico. Juntos, tiveram um casal de filhos, já casados, e nenhum vivendo na propriedade. Sobre a jornada de trabalho, nos relataram que acordam às 6 horas para tirar leite das vacas, almoçam em casa e costumam trabalhar na roça até por volta das 18 horas, porém, nos disseram que durante a colheita de tomates a jornada se intensifica e eles têm que acordar às 5 horas para tirar o leite das vacas e ir para a roça, e também voltam mais tarde para casa.

A respeito da jornada de trabalho camponesa, Shanin afirma que: 
É verdade que, no mundo em que vivemos, os camponeses trabalham mais horas do que os operários, é quase sempre assim, inclusive quando chega a época da colheita, no período de pico, tem camponeses que não dormem nem um pouco, porque este é o único jeito de manter-se. No entanto, temos que ser mais precisos, porque o camponês enfrenta trabalho duro na época da safra, mas, fora dela, não é bem assim. A situação do camponês na Sibéria, por exemplo, é a de um verão muito curto, quando ele trabalha demais, e um inverno muito comprido, quando ele trabalha muito pouco. Então, não é só uma simples questão de dizer que têm trabalho demais. Eles são, também, donos de seu próprio trabalho e assim são capazes de escolher sua própria maneira de descansar, o que é importante. Se olharmos para o camponês real, não o camponês abstrato, quando ele está trabalhando, veremos que ele é capaz de sentar-se à sombra de uma árvore numa hora quente do dia e comer um pouco da comida que trouxe de casa, saboreá-la ou até tirar uma soneca. Então, quando o calor diminui, ele retoma o trabalho, e aí ele trabalha realmente pra valer e termina o que tem que ser feito, só Deus sabe quando.

Essa é uma peculiaridade do trabalho camponês, é o trabalho de um homem que é dono do seu próprio trabalho e pode decidir como utilizá-lo. Há pessoas que preferem trabalhar mais horas em seu próprio trabalho, outras, preferem trabalhar oito horas diariamente e, depois disso, ficar totalmente livre. Primeiramente, é parcialmente uma questão de escolha, de cultura. Diferentes culturas esperam que você aja de diferentes maneiras. (SHANIN, 2008, p. 38)

Em Ribeirão Branco, durante o inverno, os camponeses também costumam diminuir o ritmo de trabalho por conta das geadas que atingem a região. Alguns, nesse período de entressafra, acabam migrando para outras áreas para se assalariarem na produção de tomates, situação que podemos observar na análise de Oliveira:

A jornada de trabalho é outro elemento componente da produção camponesa. Nesse aspecto, a realidade é toda particular. Não há uma rigidez de horário diário como na produção capitalista; a jornada de trabalho do camponês varia conforme a época do ano e segundo os produtos cultivados. Assim, combinam-se períodos chamados de ociosos, quando o camponês está livre para assalariar-se através de trabalho acessório, com períodos de intenso trabalho quando, nem o nascer e o pôr do sol, às vezes, são os limites naturais da jornada de trabalho. (OLIVEIRA, 1991, p. 64)

Durante a nossa conversa com o casal Luiz e Zeneide, eles nos contaram sobre a sua produção. Eles produzem 5 mil pés de tomate todo ano, e é esse trabalho que demanda mais mão de obra do casal. Mas produzem também frutas (caqui, pêssego e ameixa), outros legumes (abobrinha, jiló e pepino) e fazem queijos com o leite do seu rebanho. Nos disseram que, ao todo, principalmente para abrigar o gado, utilizam cerca de 10 ha de terra para o trabalho.

O que mais dá renda para nós até agora é o tomate, $70 \%$, o resto é para ir remediando. Aqui temos vacas, vende leite e queijo, tem pomar de pêssego, nectarina, ameixa, caqui e limão, nesse ano deve produzir tudo isso. Além disso, plantamos repolho, abobrinha, acelga e horta. Temos galinha, pato e ganso. (Entrevista com Luiz Gonzaga e Zeneide, 15 jul. 2015) 
Como podemos observar, mesmo uma pequena família possui uma produção diversificada. Segundo eles, é uma estratégia para que um tipo de produto possa equilibrar o outro no caso de preços baixos. Caso invistam apenas numa produção e essa não seja vendida por preços bons, a família poderá contrair dívidas.

A diversificação da produção é uma maneira de se proteger das formas predatórias de extração de renda, perpetradas por diferentes agentes do capital. Assim, quanto maior for a variedade de cultivos, criações e demais atividades afeitas, menor a vulnerabilidade e maior a possibilidade de os camponeses se apropriarem da renda gerada internamente. Combinado a isso, um caminho possível de apropriação máxima da renda se define pela eliminação dos intermediários na comercialização da produção. (PAULINO, 2012, p. 122)

O Sr. Luiz e Sra. Zeneide vendem toda a produção de frutas para o programa de compra institucional PAA e o restante vendem para atravessadores que comercializam no Ceasa. Além disso, todos os dias eles vendem leite, queijo e frutas da época na vizinhança, o que garante uma renda importante para a família.

Perguntamos sobre serem só os dois para trabalhar na sua terra e, diante de tanto trabalho com frutas, leite, queijo e roça, como seria a divisão das tarefas. O Sr. Luiz nos respondeu: "Somos só nós dois, então a gente faz tudo junto; então a mulher trabalha do mesmo jeito que eu, tudo o que eu faço, ela também faz; e eu também ajudo ela em casa. Por exemplo, no tomate, ela trabalha igualzinho eu". A Sra. Zeneide nos contou que o marido já morou sozinho em ranchos para cuidar do gado alheio e que, por isso, sabe fazer o trabalho doméstico e divide essa tarefa com ela também. Mas, quando perguntamos sobre as decisões econômicas fruto dos resultados obtidos a cada safra, ela nos disse que isso é por conta do marido. Sobre essa relação de gênero e as decisões econômicas da família, vimos em Queiroz que:

As iniciativas econômicas são de competência do marido, embora a mulher concorra para a manutenção econômica do lar, no mesmo pé em que este, isto é, labutando ao seu lado na roça. Desse modo, foi formulada a hipótese de trabalho: "a mulher, no meio rural tradicional, tem igualdade de deveres, os quais significam trabalhos, e neste ponto se equipara ao homem; mas não tem igualdade de direitos, que representam decisões, pois as decisões cabem somente ao homem". (QUEIROZ, 1973b, p. 203)

Vale dizer que a submissão econômica das mulheres não é uma situação hegemônica entre as camponesas que conhecemos durante a nossa pesquisa, como veremos adiante.

O casal Luiz e Zeneide vive desde 2006 na Associação dos Produtores da Microbacia do Rio Apiaí Guaçu - Banco da Terra, localizada no bairro Coimbra. Vivem e trabalham ali outras doze famílias, em um total de 237,16 ha - a área dividida para cada família é de 7 ha. Indagamos sobre o seu ingresso no Banco da Terra buscando compreender como foi esse 
processo e porque procuraram essa forma de adquirir sua terra. Eles nos contaram que durante toda a vida trabalharam como empregados, cuidando de gado ou plantando tomates, vivendo com muitas dificuldades. Sempre almejaram possuir uma propriedade, mas o mais perto que chegaram disso foi arrendando terra de terceiros. De toda forma, segundo o Sr. Luiz, essa não era uma boa solução, pois o proprietário sempre pedia a terra no momento em que ela estava pronta para o plantio e então eles tinham que sair e procurar outro lugar, começando tudo novamente. Portanto, segundo eles, o Banco da Terra foi uma grande oportunidade e a forma que encontraram para acessar a terra de trabalho.

Mas, segundo o Sr. Luiz, isso não resolveu todos os problemas. Ele afirma que a falta de acesso ao crédito é um problema para eles e que se isso fosse facilitado estariam em melhores condições de vida. “Aqui falta muito acesso a crédito, aqui é muita burocracia. A gente vê falar que existe, mas a gente vai no banco e eles tiram sarro da cara da gente ainda, aqui isso é muito difícil” (Entrevista com Luiz Gonzaga e Zeneide, 15 jul. 2015).

Além da falta de crédito, Sr. Luiz faz outra observação: “A terra demorou muito a chegar para nós. A gente trabalha de dez a doze anos para conseguir uma pequena estrutura para trabalhar, aí, pra quem já está meio de idade, não dá mais tempo de arrumar a vida, de fazer os investimentos que tem que ter no sítio" (Idem).

Apesar do Sr. Luiz lamentar que a terra tenha vindo tarde e que por isso não conseguiu uma vida com mais conforto, é visível em sua propriedade a fartura de alimentos e uma condição muito distante da pobreza que encontramos nos grandes centros urbanos.

Paulino, sobre as dificuldades e condições de vida dos camponeses, afirma que:

Portanto, por maiores que sejam as dificuldades econômicas desses camponeses, o empobrecimento não pode ser relacionado a uma situação de miséria absoluta, tão comum entre trabalhadores marginalizados nas cidades. Pelo menos do ponto de vista do acesso aos alimentos, isso não se aplica, já que, em geral, os mesmos têm uma mesa variada e farta. São consumidos ovos, leite, verduras, legumes, cereais e carne, oriundos da produção própria, a qual ocupa lugar de destaque na lógica de reprodução da família.

Assim, ao afirmarem que a situação no campo está muito difícil, sempre se referem aos preços que devem pagar para produzir e o que podem receber ao final, transações que se situam no interior do circuito monetário. Por outro lado, quando o assunto é tratado no interior das relações não monetárias, o que inclui a produção para o autoconsumo e o próprio trabalho, a avaliação é oposta: em um mundo onde tantas pessoas em situação social idêntica à sua padecem de fome, eles garantem seu próprio alimento em situação de ponderável fartura. (PAULINO, 2012, p. 359)

Uma realidade semelhante a essa apontada por Paulino, encontramos no sítio do casal Luiz e Zeneide: havia um pomar com inúmeras frutas, horta variada, pequenos animais como galinhas, patos, gansos, angolas, cabritos e até porcos, além do gado. Na hora do café que nos 
foi servido, também não passou despercebida a geladeira cheia de leite e queijos para serem vendidos nos próximos dias.

A exceção ficaria a cargo do gado leiteiro, mas aqui há que se fazer observações. Dentro dos sítios camponeses que não têm a pecuária leiteira como principal atividade comercial, sua presença é um indicativo de uma situação mais estável da família. (PAULINO, 2012, p. 248)

Com o Sr. Luiz e Sra. Zeneide, observamos que o trabalho com o gado serve como um tipo de poupança que pode ser acessada em momentos de crise, além disso, daí garantem uma renda fixa com a venda de leite e queijo.

Quando indagado sobre o processo de ida para a associação do Banco da Terra, o Sr. Luiz nos respondeu que, mesmo diante das dificuldades encontradas pela falta de financiamentos para o plantio e com a dívida da terra para quitar, valeu a pena a decisão:

Olha, eu aconselho o povo que compensa ir pro crédito fundiário sim, pois a gente ficar trabalhando só de empregado, só enche a barriga de patrão e a gente nunca tem nada. Então aqui a gente fica com a família, tem um lugar pra ficar. É terrível a gente plantar uma lavoura aqui e então ter que carregar a mudancinha para Mogi [Guaçu] pra plantar outra lavoura e não ter um lugar fixo. Você nunca tem mais do que uma mísera mudancinha pra carregar que vai estragando tudo. Tendo a terra e crédito para trabalhar, se você pensar em produzir e ir criando um meio de vida, tudo bem, agora, se você pensar em entrar na terra pra ficar rico você está enganado! (Entrevista com Luiz Gonzaga e Zeneide, 15 jul. 2015)

Essa fala do Sr. Luiz é carregada de significados e expressa a negação de ser empregado. Ele analisa que quem assalaria enriquece com o trabalho do assalariado, assim como trata da dura vida do trabalho no campo - como que querendo dar um recado de que deixar de ser assalariado não é sinônimo de vida tranquila.

Em nossa próxima entrevista, buscamos conhecer famílias que estão no novo programa, o PNCF.

Nessa associação, dialogamos com o Sr. Wilson, que é morador do bairro da Serra Velha, onde está localizada a Associação de Agricultores Familiares Águia Dourada - Crédito Fundiário, bairro Serra Velha, criada especificamente para atender aos critérios do programa de acesso à terra. A associação é formada por cinco famílias de irmãos numa área de 26 ha e foi, em 2005, a primeira do estado de São Paulo a acessar o PNCF.

Conversamos com Wilson, que nos contou que frequentou o ensino fundamental, e sua esposa, Dulcelene, que estudou até a terceira série do ensino fundamental. O casal tem três filhos que moram com eles: Johny, de 18 anos, Rafael, de 14, e Luiza, de 8. Wilson nos relatou que trabalha na roça desde os seus 8 anos de idade e, até 1990, trabalhou nas fazendas de tomate. 


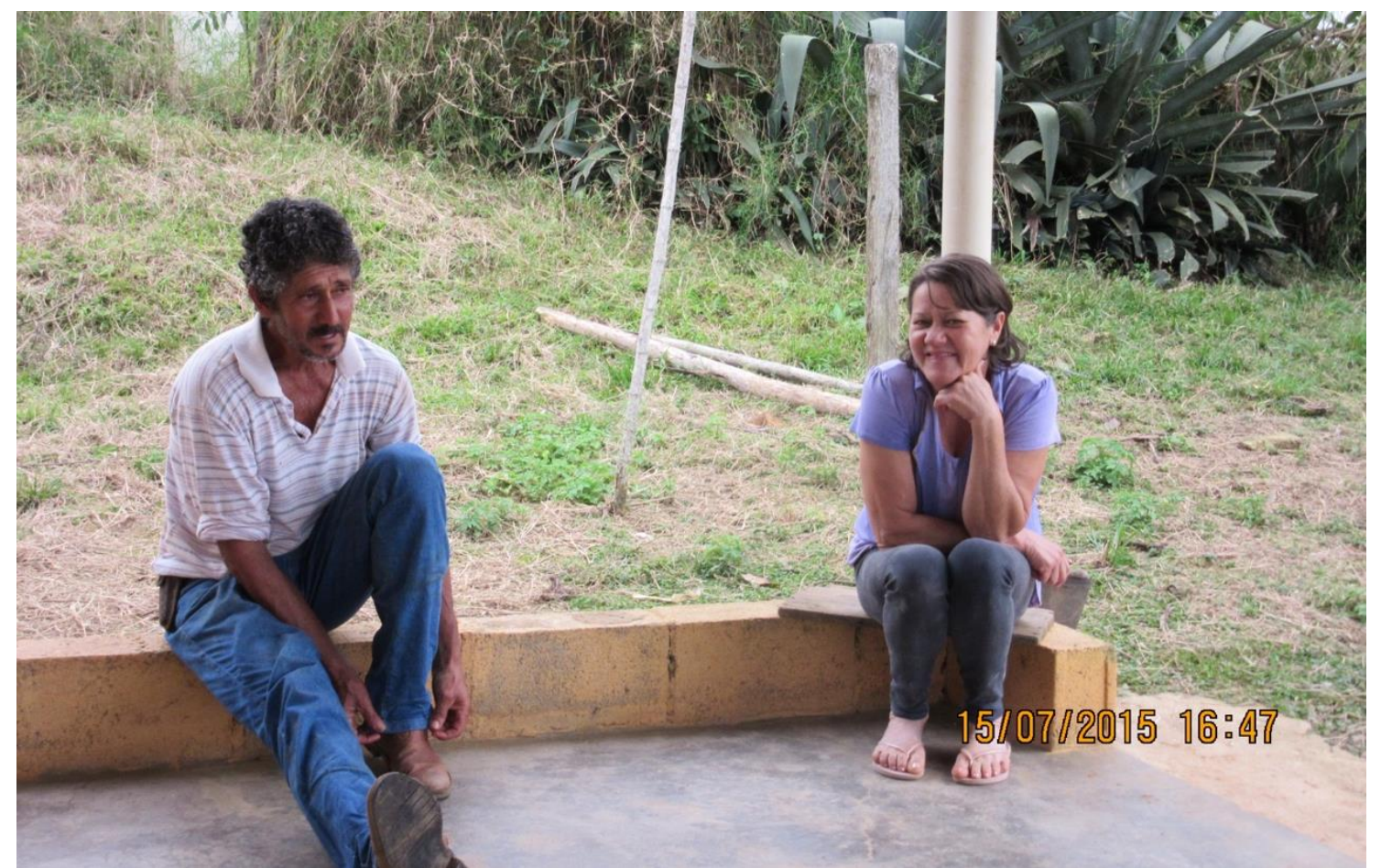

Foto 35: O casal Luiz Gonzaga e Zeneide durante a entrevista na Associação dos Produtores da Microbacia do Rio Apiaí Guaçu - Banco da Terra, bairro Coimbra.

Foto: Lucinei Paes de Lima, jul. 2015.

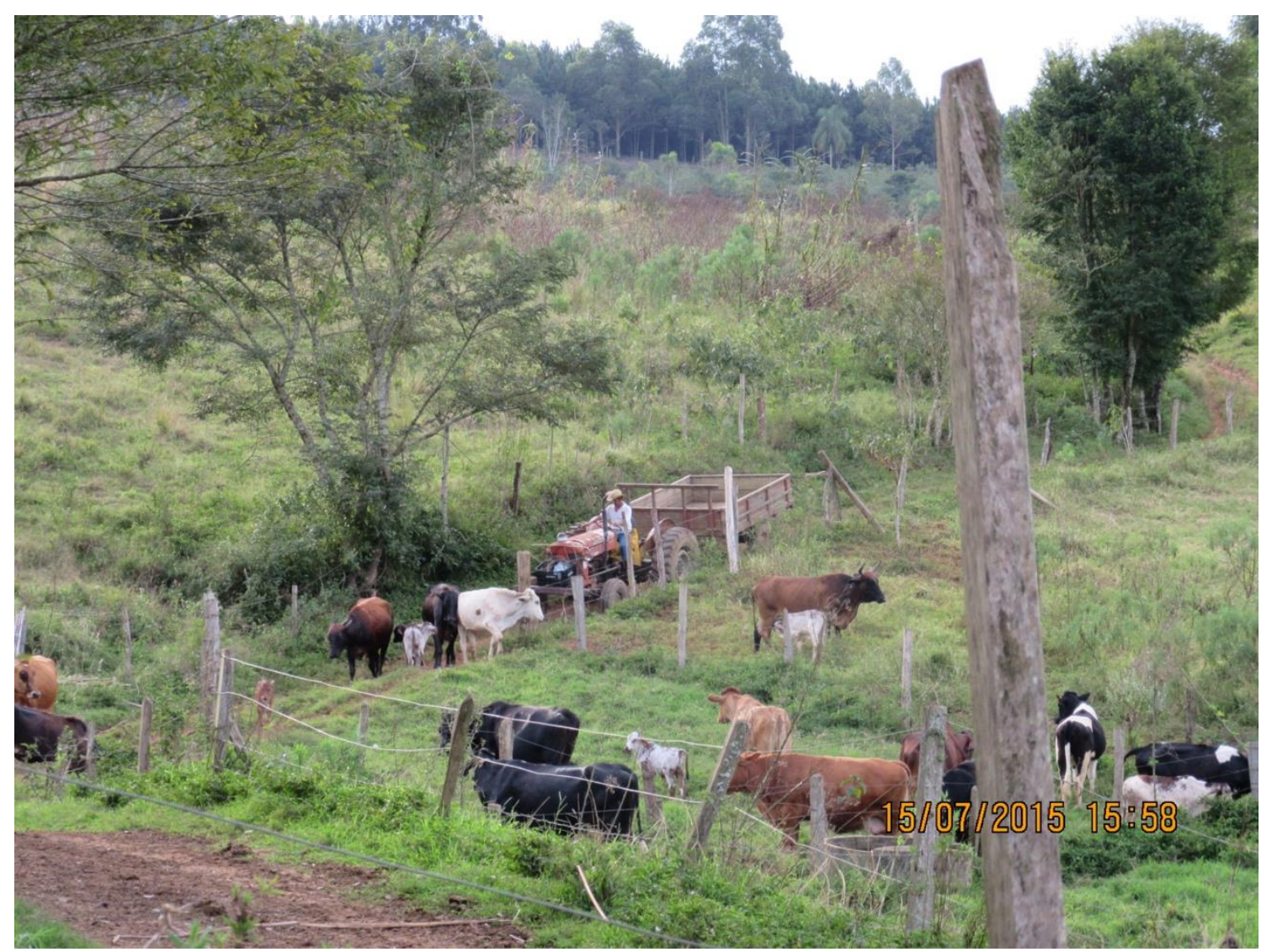

Foto 36: O gado do Sr. Luiz e da Sra. Zeneide. Associação dos Produtores da Microbacia do Rio Apiaí Guaçu - Banco da Terra, bairro Coimbra. Foto: Lucinei Paes de Lima, jul. 2015. 
Essa associação tem uma diferença em relação às demais visitadas por estar parcialmente organizada em torno do trabalho coletivo: as cinco famílias produzem e comercializam brócolis, repolho, acelga, beterraba, cenoura, cheiro verde, alface, couve, chuchu e jiló. Wilson nos disse que $40 \%$ do trabalho na associação é coletivo, e esse trabalho é responsável pela maior parte da renda de todas as famílias. Além da área coletiva, cada família tem a sua própria horta. De acordo com Wilson, a média da renda anual de 2016 ficou em torno de 40 mil reais, e é dividida entre as cinco famílias, sendo a maior parte resultante da venda para o PAA. Sobre a jornada de trabalho, nos disse que não costumam ultrapassar as 8 horas diárias, acordando às 7 e trabalhando até cerca de 18 horas.

Além dos programas institucionais, o grupo de famílias também vende a sua produção direto ao consumidor, montando cestas e entregando de porta em porta na cidade e para os trabalhadores assalariados das fazendas de tomate. Ao todo, produzem e entregam 210 kits de verduras a cada 15 dias. O que ainda sobra da produção, comercializam com os donos de mercadinhos e restaurantes na cidade.

Tudo é anotado numa planilha em um caderno, onde também está a escala de trabalho de cada integrante do grupo. Por exemplo, no início da semana um dos membros da associação vai para a cidade com a tarefa de apresentar para os já consumidores a lista de produtos disponíveis naquela semana. Cada consumidor escolhe os produtos da lista e monta a sua própria cesta. No dia da entrega, os produtos são colhidos, lavados e separados em sacolas e caixas com o nome de cada consumidor. A entrega é feita na casa de cada um. Segundo Wilson, os produtos são semiorgânicos porque ainda não conseguiram recuperar a terra dos muitos anos de uso de agrotóxicos, mas esse é o objetivo da família, trabalhar e vender alimentos saudáveis.

Na Foto 37, o processo de montagem das cestas de verduras para serem entregues direto aos consumidores.

Perguntamos como era o trabalho das mulheres na associação e Wilson nos disse que houve uma deliberação sobre esse assunto e que as mulheres, além de trabalharem na parte coletiva da associação, também têm uma produção individual, e elas administram como querem a renda obtida com essa produção. Ele garante que, desse modo, toda semana elas têm uma renda e que esse valor não é contabilizado nas despesas gerais da associação, como ocorre na produção coletiva com gastos como, por exemplo, a mecânica e a manutenção da caminhonete utilizada nas entregas e a compra de ferramentas e insumos de trabalho. Além disso, segundo ele, elas já contribuem com os alimentos mais essenciais, a criação de frangos, ovos e os cuidados com a comida, os filhos e a casa e, portanto, seria justo ter uma renda para elas utilizarem como bem entenderem. 


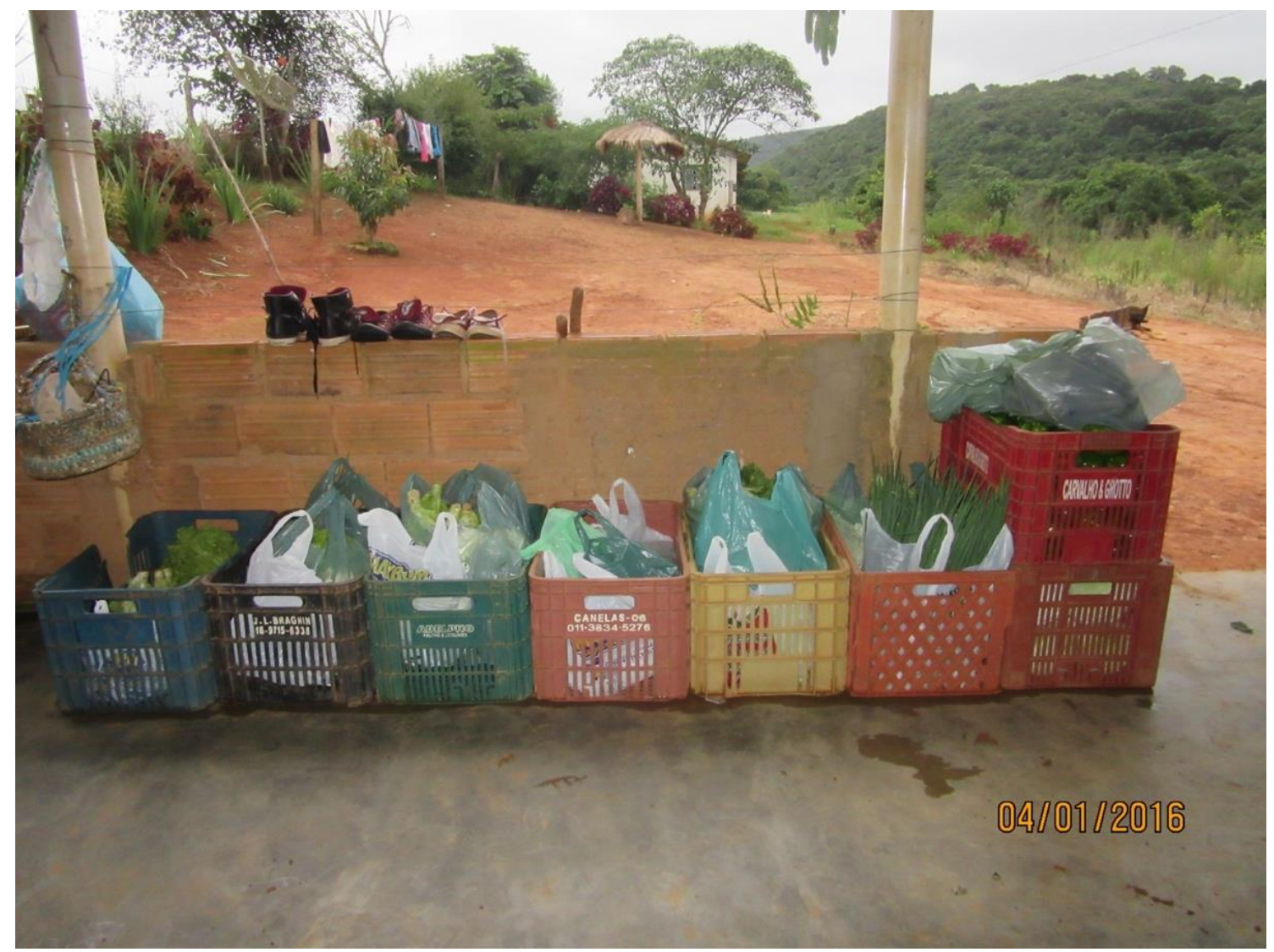

Foto 37: Cestas de verduras separadas para serem entregues direto aos consumidores. Associação de Agricultores Familiares Águia Dourada - Crédito Fundiário, bairro Serra Velha. Foto: Lucinei Paes de Lima, jan. 2016.

De toda forma, durante a conversa com as mulheres dessa associação, não ficou clara a utilização do dinheiro obtido da produção individual.

O trabalho da casa cabe à mulher; mãe e filhas a partir da faixa de idade de sete a nove anos. Este trabalho no lar é também para o lar, ou seja, aquelas tarefas que visam a assegurar bens alimentícios, objetos ou serviços que servem à sobrevivência dos membros da casa. (MOURA, 1978, p. 19)

Wilson nos relatou que, assim como no caso das mulheres, a associação também havia definido que seria importante garantir uma renda para os jovens comprarem bens que satisfaçam às suas próprias necessidades, como aparelhos de música, celulares e até motocicletas. Nos disse que conforme vão crescendo, eles escolhem que tipo de plantação gostariam mais de cuidar. Eles produzem cenoura, beterraba e abobrinha dentre outras coisas, diferentemente das mulheres que, nesse período da entrevista, estavam plantando cheiro verde, couve e alface. Segundo o Sr. Wilson, os jovens da associação preferem trabalhar individualmente, mas, em alguns momentos, também se envolvem nos trabalhos coletivos. Toda a produção é vendida junto e depois eles separam a renda obtida. 
Alguns gostam mais da roça e outros falam de sair, mas pode ser que mudem de ideia, pois, com esse sistema de garantir renda, já compraram moto e as coisinhas deles, e estão animados este ano. Eles compram roupas, celulares, calçados, som. A gente não pode comprar, então eles se viram e dão o seu jeito. (Entrevista com Wilson Rodrigues de Souza, 13 jul. 2015)

Procuramos saber mais sobre o trabalho coletivo da associação e Wilson nos fez o seguinte relato:

Aqui a gente não divide a terra das cinco famílias não, e, na parte coletiva, tem uma escala [de trabalho]. Para tirar o leite, o João, que gosta de tirar leite, ele tira todos os dias, e outro é escalado para ajudar ele.

O carro também é coletivo. Na hora de consertar o carro, é dividido as despesas com as notas [fiscais] de cada arrumação. Ninguém tem dinheiro na hora, então sempre tem um fundo para emergências para ajudar. Cada família tem uma DAP [declaração de aptidão ao Pronaf], mas é tudo coletivo, que a gente administra e divide as despesas e receitas tudo.

Eu acho que seria bom que cada associação do Crédito Fundiário e Banco da Terra tivesse uma parte coletiva, mas é difícil, pois até aqui, que somos todos irmãos, tudo da mesma família, tem hora que não é fácil.

Aqui a gente tem o gado coletivo também, cada família tem direito a um litro de leite e aí divide assim a escala de serviço: um separa bezerro de terça e sábado, outro, nos outros dias, e assim por diante. Para molhar os viveiros de muda também é desse jeito, tem uma escala com os nomes e os dias certos.

Aqui sentamos e fazemos cronograma numa lousa grande, senta de 15 em 15 dias para ver se estamos seguindo o planejamento para nossa sobrevivência. Isso não é fácil, é difícil. (Idem)

Perguntamos sobre a relação da associação, o pagamento das parcelas da dívida da terra e qual estratégia utilizavam para saldar essa dívida. Wilson nos respondeu que realmente a dívida é cara para pagar, mas que o maior problema nem era esse e sim a falta de assistência técnica para acompanhar as famílias que acessam o programa do Crédito Fundiário e ficam sem saber como lidar com a burocracia do projeto.

O problema maior é a falta de alguém nos dar assistência, todos os dias mudam as normativas e é muita burocracia. A gente nunca sabe direito como estão as negociações e falta informação clara para nós. O que sabemos é que a nossa dívida da associação... a dívida da terra é de 15 mil reais por ano, porque foi pago o valor de 12 mil reais por alqueire. Se a gente pensar nesse valor hoje, jamais seria possível comprar uma terra dessa. Hoje, o valor do alqueire aqui está em 25 mil reais. (Idem)

Segundo o Sr. Wilson, o objetivo da associação é construir um projeto que priorize a produção de alimentos saudáveis e que isso sirva de exemplo para os outros bairros rurais do município. Ele nos contou que as terras da associação ainda têm resíduos de agrotóxicos, o que inviabiliza a tentativa de certificar os produtos cultivados. "O município sofre com a produção do tomate que envenena as nossas terras e rios. Não é possível a gente continuar envenenando a nós mesmos e a quem come o que produzimos. É preciso olhar mais pra isso!” (Idem). 
Sobre o preço dos seus produtos, perguntamos se havia diferença por ser um produto mais saudável e ele nos disse que não tem diferença dos outros produtos convencionais, vendem pelo mesmo preço. Nos informou que na época desta entrevista (janeiro de 2016), os produtos da associação estavam sendo comercializados pelo valor de 1 real cada item. Ou seja, o consumidor escolhe a partir de uma lista elaborada pela associação e se, por exemplo, pedir dez tipos de produtos diferentes, pagará por essa cesta 10 reais. Todos os produtos - abobrinha, cebolinha, couve etc. - custam o mesmo valor de 1 real cada. A couve e o cheiro verde são por maço, a alface por pé, a cenoura ou a beterraba vão num saquinho com um certo número de unidades.

Por último, perguntamos o que os moradores da associação faziam nos momentos de folga e Wilson nos falou que todos são envolvidos com as atividades do bairro, como os eventos futebolísticos, tanto as mulheres quanto os homens da família, além de fazerem parte do conselho da igreja e da organização das festas da comunidade.

O trabalho independente possibilitava aos sitiantes o deslocamento para festas, para compras, para visitas, para cumprir um dever religioso, quando e como quisessem. Seu horário de trabalho era por eles mesmos estabelecido, em função da necessidade econômica, mas também em função de suas concepções sobre as práticas religiosas e sobre o lazer. Esta independência sempre foi muito prezada, e sempre constituiu um valor que se desejava salvaguardar o mais possível, à custa de sacrifícios se necessário. (QUEIROZ, 1973a, p. 94)

Como podemos ver, existe uma agenda dedicada à religiosidade e às atividades de lazer. Sobre esse assunto, retomaremos no capítulo 7 deste trabalho.

Tivemos a oportunidade de conhecer outra realidade protagonizada pela camponesa Sra. Zilda Fortes, moradora do bairro do Rio Apiaí. Diferente das entrevistas anteriores, ela não é proprietária, portanto, não tem terras para trabalhar e, por isso, arrenda terra dos vizinhos do bairro. Ela mora com o marido, Sebastião, e juntos eles têm um filho já casado, que mora vizinho deles. Zilda nos contou que ela e o marido não trabalham juntos, segundo ela, isso não dá certo porque cada um tem um jeito de fazer o serviço e isso gera muitos conflitos. Assim, cada um tem o seu trabalho: o marido trabalha por dia para os vizinhos do bairro e também arrenda terra para plantar, mas sempre em outro lugar, distante da plantação da esposa. A Sra. Zilda nos concedeu a seguinte entrevista sobre a sua relação com a terra que precisa arrendar e a sua produção: 


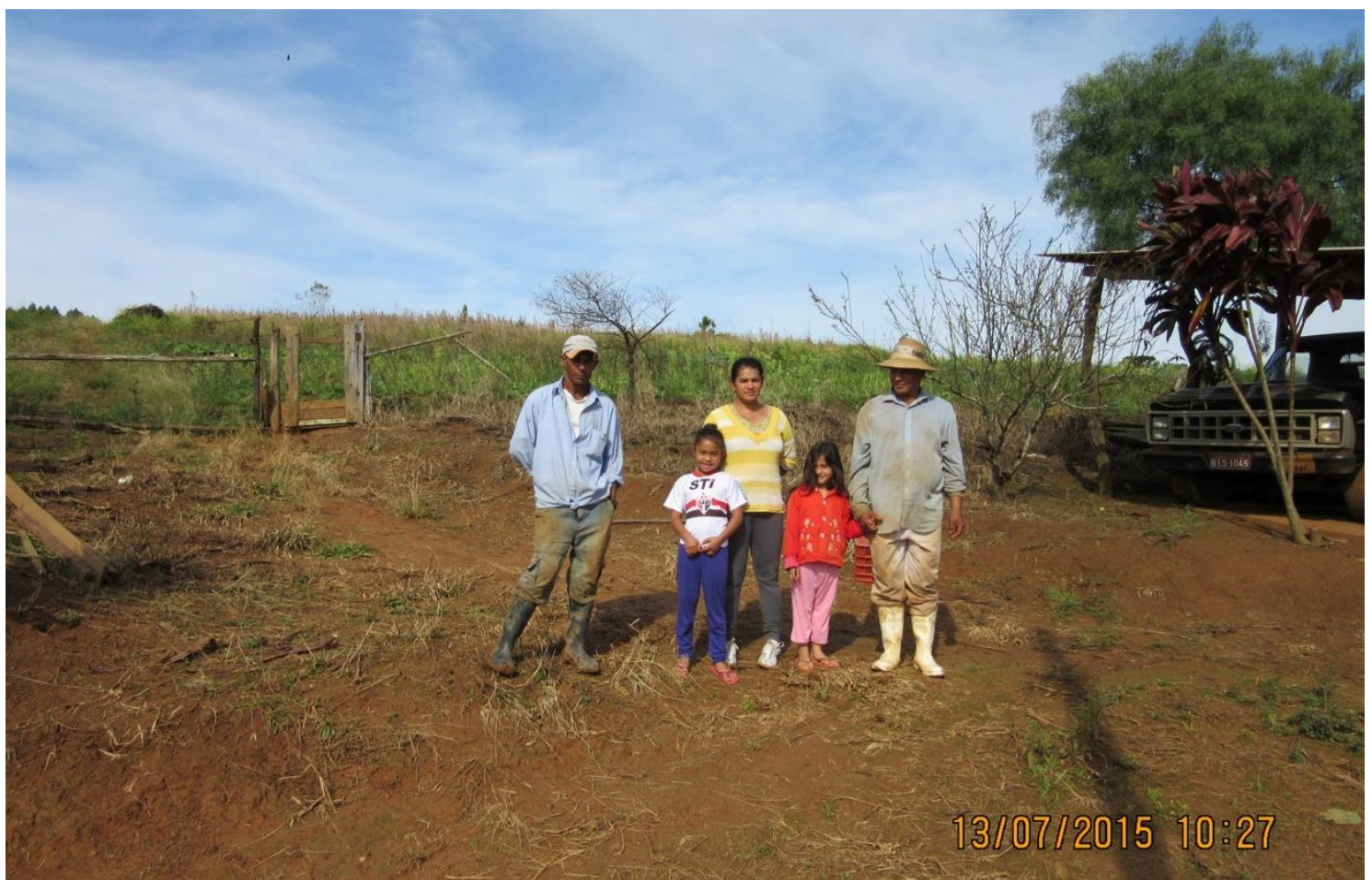

Foto 38: Os irmãos Laércio, Claudinéia e Wilson, à direita. Associação de Agricultores Familiares Águia Dourada - Crédito Fundiário, bairro Serra Velha. Foto: Lucinei Paes de Lima, jul. 2015.

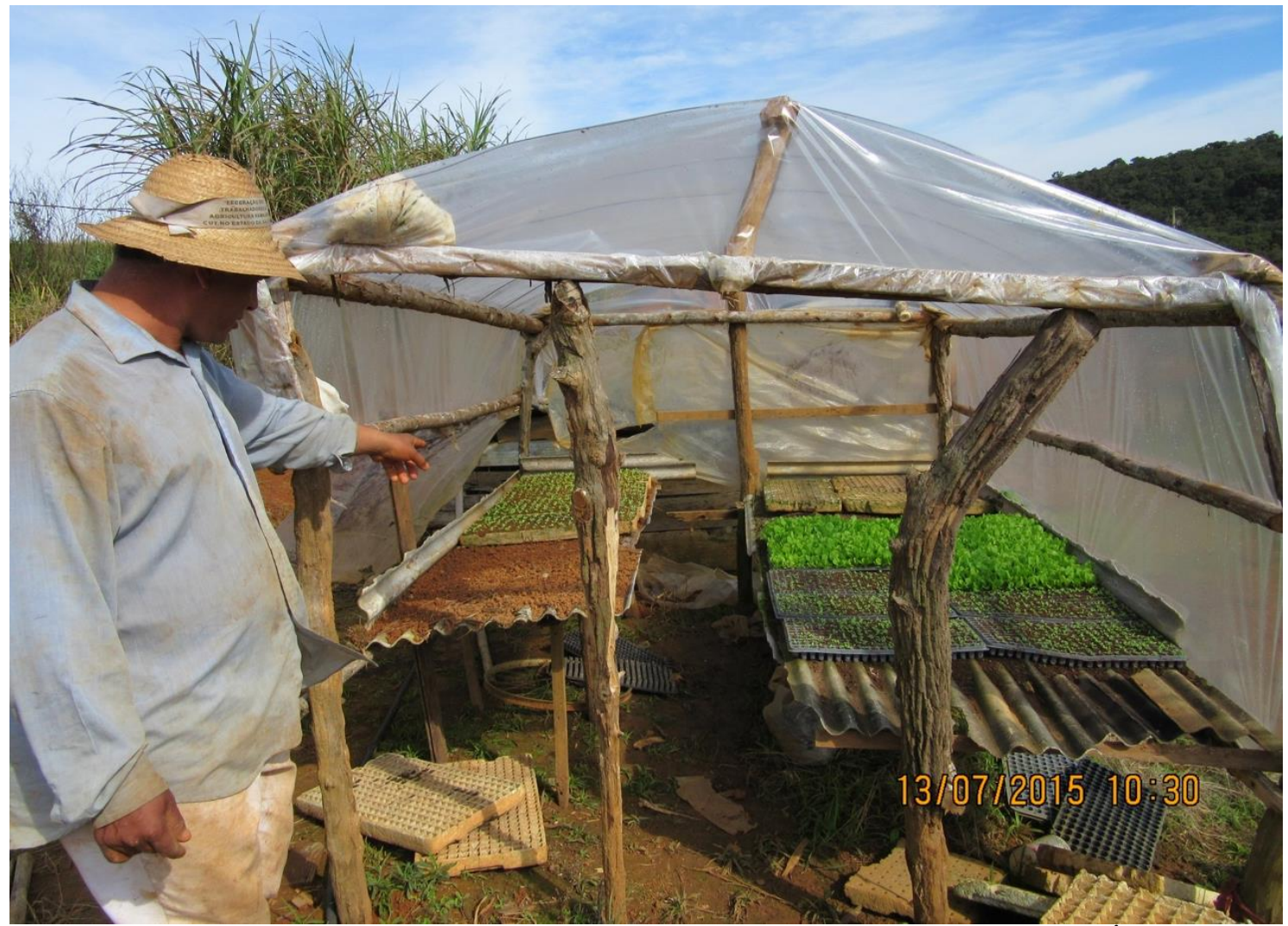

Foto 39: Estufa de mudas para o plantio, Associação de Agricultores Familiares Águia Dourada - Crédito Fundiário, bairro Serra Velha. Foto: Lucinei Paes de Lima, jul. 2015. 
Lucinei: Qual o tamanho da terra que você arrenda?

Zilda: É quinze tarefas, não chega dar bem um hectare de terra.

Lucinei: Quanto você paga para usar essa terra?

Zilda: Eu pago, por ano, 1,5 mil reais, mas é para usar o ano inteiro, e esse valor é porque é com os vizinhos mesmo.

Lucinei: Mas você usa a terra também no inverno?

Zilda: Claro, pago o arrendamento por ano, planto ano inteiro. No inverno, planto repolho, cebola, ervilha, couve-flor, coisa do frio mesmo, mas daqui sai coisa o ano inteiro! Tiro uma coisa e já coloco outra! E ainda tenho o feijão, milho e até a mandioca que é demorada!

Lucinei: Quais são os produtos que vocês cultivam?

Zilda: Tomate, vagem, abobrinha e repolho é para o gasto; feijão e milho, batatinha, cebola, alho, mandioca, tem laranja e banana, batata doce e tem galinhas, ovos, laranja, banana. Ah, eu também faço sabão caseiro para os vizinhos. Eles entregam pra mim a gordura usada e então nós dividimos o sabão feito meio a meio. (Entrevista com Zilda Fortes, 12 jul. 2015)

Como podemos ver, num espaço com menos de um hectare a Sra. Zilda produz uma ampla diversidade de alimentos. Vale destacar que, quando ela menciona a laranja e a banana, esses dois são produzidos no quintal da sua moradia e não na terra arrendada. Mas, como ela mesma disse, a produção é o ano todo e a família tem produtos para consumir e vender durante os doze meses. Acreditamos que, mesmo desse modo, tendo que pagar a terra para produzir, isso ainda é conveniente. Como podemos ver em Chayanov:

És evidente que la unidad campesina de explotación doméstica considera que vale a pena pagar arrendamiento por una parcela que le permita lograr su balance interno en un punto de equilibrio, entre las fatigas del trabajo y la satisfacción de sus necesidades, más favorable que el que lograría sin esa tierra. (Chayanov, 1974, p. 277)

Zilda nos contou que a maior renda dela vem da produção de tomates - que, em 2016, foi de 3 mil pés - e que, na sua maioria, ela vendeu para o PAA e o Pnae. O que não foi para os programas institucionais foi enviado para o Ceasa, levado pelos atravessadores. Perguntamos sobre como ela escolhe para qual atravessador vender e ela nos contou que, na maioria das vezes, é quem chega primeiro e, se já estiver na hora de colher o seu produto, ela o entrega. Dependendo do comprador, o pagamento acontece só no final da lavoura, a cada 15 dias ou, no caso dos "melhores", em até 8 dias.

O problema é que a gente só é pago no final da lavoura. Então, pra você vê, a gente trabalha três a quatro mês no tomate, sendo que a colheita dura cerca de um mês, então a gente vai entregando toda a mercadoria e muitas vez sem saber quanto tá valendo. Então os homem só acaba de pagar a gente às vezes mais de mês depois que acabou a lavoura, porque, às vezes, dão cheque pra 30 e 60 dias ainda, pra gente descontar no banco. Então, você vê que quando a gente pega dinheiro, já venceu as contas tudo, de mercado, de loja e de tudo. (Idem) 
Quando a nossa interlocutora diz "loja", ela está se referindo ao lugar onde compra os insumos agrícolas para produzir o tomate, como, por exemplo, os adubos, as ferramentas, as mangueiras para fazer a pulverização, os venenos para o controle de pragas etc. Zilda nos relatou as dificuldades da roça:

Lavoura é assim, é sofrido. Quem lida na roça sabe o gosto da coisa aqui, trabalha muito e ganha pouco, as coisas não têm preço pra gente vender e fica só em serviço da gente. O problema é que a gente compra muito caro e o que a gente planta é muito barato. (Idem)

Mesmo diante de tantas dificuldades, pagando renda da terra e do trabalho bruto da roça, quando questionamos sobre a possibilidade da sua família ir embora para a cidade, a resposta veio de forma apressada:

De jeito nenhum! Eu nunca tive vontade de largar e ir pra cidade porque aqui no mato a gente tem de tudo um pouquinho... pra gente ir pra cidade, só se a gente não aguentar trabalhar, não puder de jeito nenhum ficar mais na roça, porque na cidade é muito difícil. Porque todas as coisas a gente têm que comprar, de cebolinha pra cima, um ovo de galinha... aqui a gente rebate bastante as despesa. (Idem)

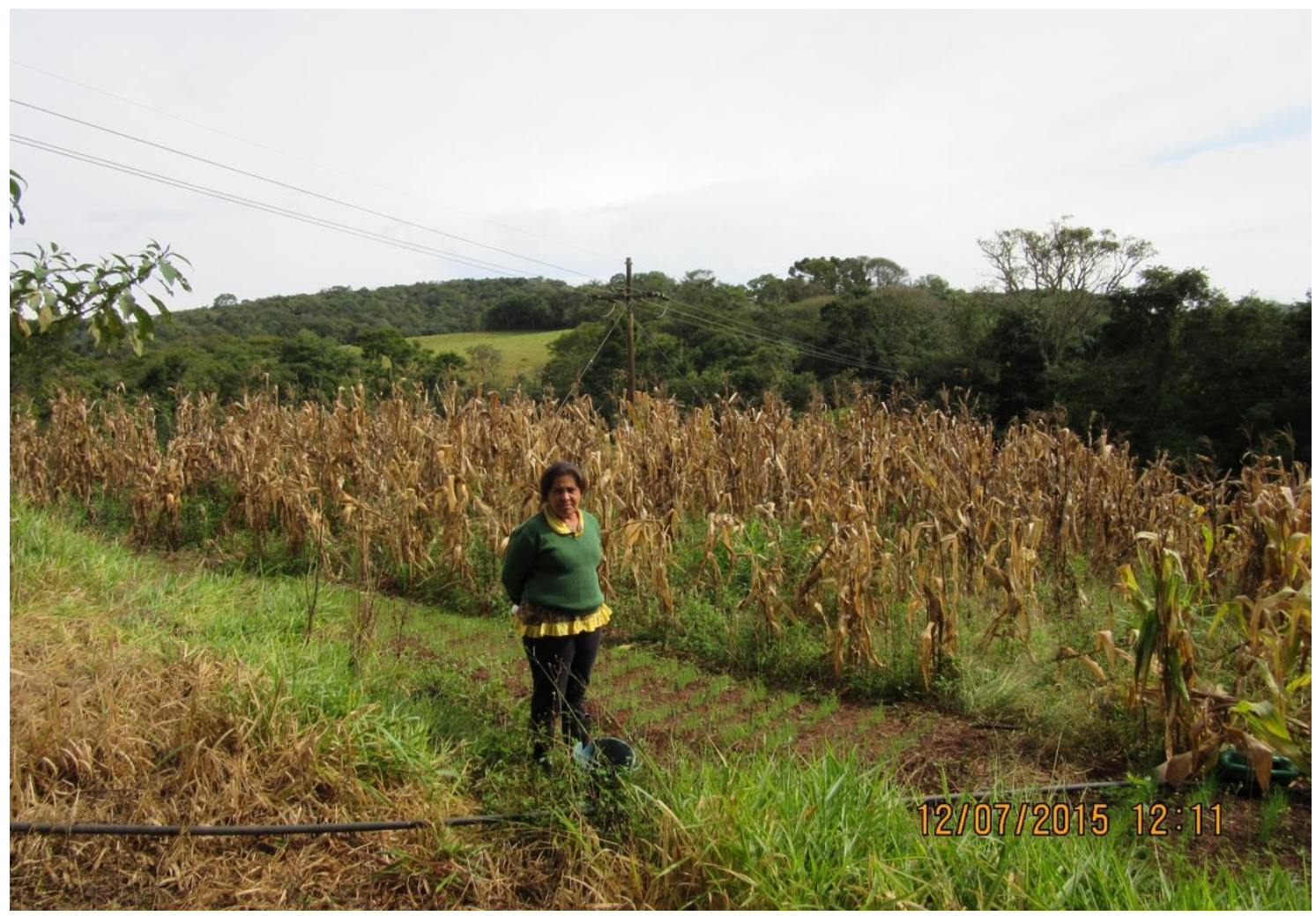

Foto 40: Sra. Zilda na sua plantação de milho, bairro do Rio Apiaí. Foto: Lucinei Paes de Lima, jul. 2015. 
Ou seja, a vida é muito difícil na roça, mas, para a nossa interlocutora, na cidade seria ainda mais difícil.

Por fim, perguntamos a Sra. Zilda sobre os momentos de folga do serviço da roça e o que ela costumava fazer. Ela nos respondeu que não abre mão das festas que acontecem nos bairros, onde ela se diverte jogando bingo.

Vimos, neste capítulo, as diferentes trajetórias de vida e de retorno e acesso à terra de trabalho dos camponeses de Ribeirão Branco - trajetórias que garantem a recriação camponesa. Paulino também estudou as formas de acesso à terra:

Portanto, a conquista da autonomia se dá por diversos caminhos. Encontramos alguns que chegaram a essa condição graças à decisão da justiça de lhes conceder legalmente a propriedade de uma terra trabalhada por duas gerações. Por outro lado, encontramos filhos de camponeses que acabaram se proletarizando, mas, como empregados, foram acumulando para a compra da terra própria. Alguns comprando algumas vacas e vendo o rebanho crescer, apascentando-se em beiras de estrada, pagando aluguel de pasto, algumas vezes ao próprio patrão.

Outros arredando concomitantemente ao assalariamento, contando com a força de trabalho da esposa e dos filhos [...].

São inumeráveis as estratégias utilizadas na conversão para camponeses proprietários. Evidentemente, após alçados a essa condição, o desafio passa a ser a permanência na terra, sendo necessário recorrer a diversos expedientes para extrair dela o suficiente para o sustento da família. (PAULINO, 2012, p. 348-349)

E, dessa forma, com base em seus próprios depoimentos, podemos afirmar que essas famílias dão continuidade a trajetória do campesinato por uma vida com a máxima autonomia e liberdade possíveis. No capítulo seguinte, discutiremos sobre esse modo de vida - o modo de vida camponês. 


\section{Modo de vida camponês}

O fazendeiro possui a terra, o burguês tem o capital e o proletário vende força de trabalho. E o camponês? O que possui? O que produz? O que vende? O dinheiro que recebe é uma renda, um lucro ou um salário? O camponês pode ter terra e até um módico capital, vende ou come o que planta e pode contratar temporariamente peões, outras vezes é ele mesmo que vende sua força de trabalho por um salário. (BARTRA, 2011, p. 67)

O camponês tem sido objeto de importantes análises que permitiram uma melhor compreensão sobre a sua trajetória. A análise de Moura (1978), mesmo que realizada há quase quarenta anos, permanece atual. Moura afirma que é importante caracterizar o que seria o modo de vida camponês - um grupo social ainda relevante numericamente - e, dessa forma, resgatar e reconhecer uma face bastante expressiva das lutas populares do mundo contemporâneo. Segundo a autora, muitos cientistas sociais acreditavam em um fim inevitável para o campesinato. Todavia, ele continua "perturbando" os estudiosos com as suas persistentes formas de criações e recriações.

É também verdade que o camponês tem despertado uma ânsia de pesquisa bastante peculiar. Várias razões podem ser levantadas para explicá-la: há o fato de o camponês controlar terra no capitalismo sem ser possuidor de capital, na acepção marxista da palavra; há também o fato de o camponês ser uma espécie de pomo de discórdia sobre a natureza de classe das revoluções que implantaram ou derrubaram historicamente a ordem burguesa; há ainda o fato de o camponês trabalhar com a ajuda da família, à qual não remunera segundo a ótica capitalista, isto num mundo marcado pelo contrato individual de trabalho e pelo pagamento em salário das tarefas desempenhadas; resta assinalar o fato de o camponês lutar por formas culturais e sociais próprias de organização, sem ser ou poder se concretizar como outro povo ou outra cultura, estranhando, mais do que recusando, a sociedade abrangente que o contém e circunda. (MOURA, 1978, p. 8)

Para Moura, o campesinato é capaz de adaptar-se às transformações socais e econômicas e garantir a sua reprodução em diferentes momentos e processos históricos - e é nesse sentido que a autora faz a crítica àqueles que visualizam o fim do campesinato.

Indicariam tais transformações o desaparecimento do campesinato? Em determinados contextos históricos, esta foi de fato a tendência predominantemente. Na maioria, porém, o camponês adaptou-se e foi adaptado, transformou-se e foi transformado, diferenciou-se internamente, mas permaneceu identificável com tal. Teve suas formas de produção e organização de vida redefinidas e, em larga medida, postas a serviço de uma realidade estrutural mais poderosa: a engrenagem de reprodução do capital. (MOURA, 1978, p. 18-19)

Sobre esse assunto, Fabrini critica a análise sobre o referencial teórico que serve como fundamento para uma certa teoria que discute a possibilidade do desaparecimento do 
campesinato. Essa teoria interpreta o campesinato como um sujeito conservador que não seria capaz de lutar para superar a condição de existência que a pequena propriedade lhe impõe:

O referencial teórico marxista procurou interpretar o campesinato no contexto da produção capitalista e na sociedade de classes. Nesta concepção, o camponês foi teorizado pelo seu fim, ou seja, não havia lugar para ele na sociedade capitalista e nem na socialista. Tendo em vista a forma como o camponês estava inserido no mundo da produção, não era possível continuar sua existência como classe devido à dificuldade de consciência e de práticas coletivas de produção. (FABRINI, 2014, p. 29)

Fabrini aponta a necessidade de compreendermos que, com o avanço do capitalismo, o agronegócio se tornou a nova face da agricultura. Nesse sentido, segundo ele, é preciso interpretar obras como O 18 de Brumário de Luís Bonaparte (MARX, 1987) ou O camponês na França e na Alemanha (ENGELS, 1981) como a realidade política vivida naquele período histórico, sem ser possível realizar transposições meramente mecânicas daquele período para o moderno capitalismo do século XXI.

Um importante referencial sobre o conceito de campesinato é a obra de Chayanov (1974) que, embora trate do campesinato russo na década de 1920, nos apresenta elementos fundamentais para compreendermos a dinâmica do campesinato brasileiro no século XXI.

Para Chayanov, é o trabalho da família que define primeiramente o camponês, a partir da não existência do fenômeno salário e da ausência do cálculo capitalista do lucro. Nesse sentido, o trabalho da família tem como objetivo final a satisfação de suas necessidades e é esse fator que determina o grau de fadiga e autoexploração da mão de obra familiar - ou seja, a família camponesa se realiza em relações não capitalistas de produção.

Por eso es que el limite más elevado posible para el volumen de la actividad depende del monto de trabajo que puede proporcionar esta fuerza de trabajo utilizada con la máxima intensidad. De la misma manera, el volumen más bajo está determinado por el total de beneficios materiales absolutamente esenciales para la mera existencia de la familia. (Chayanov, 1974, p. 47-48)

Também, segundo o autor, a família camponesa não se confunde necessariamente com a biológica, mas seria efetivamente constituída pelas pessoas que residem e consomem os resultados da produção daquela casa. Por outro lado, as necessidades da família variam de acordo com o consumo e a capacidade da força de trabalho, levando em conta o ciclo da família, ou seja, o próprio ciclo da vida, no qual, por exemplo, em um período existem mais crianças que adultos, em outro, essas crianças poderão contribuir com a sua força de trabalho e, por último, haverá idosos que já não possuirão as mesmas condições para exercer o trabalho e contribuir com as suas necessidades. Além do mais, é importante destacar que o trabalho na 
terra não é a única atividade executada, mas o trabalho artesanal também faz parte da vida camponesa.

Cada familia, entonces, según su edad, constituye en sus diferentes fases un aparato de trabajo completamente distinto de acuerdo con su fuerza de trabajo, la intensidad de la demanda de sus necesidades, la relación consumidor-trabajador, y la posibilidad de aplicar los principios de la cooperación compleja. (Chayanov, 1974, p. 55-56)

Podemos observar essa realidade no trabalho de campo realizado no município de Ribeirão Branco, onde encontramos crianças e idosos desenvolvendo suas tarefas e contribuindo com a rotina de trabalho das famílias. ${ }^{20}$

Em Chayanov (1974), o camponês é que gere a sua própria unidade de produção, obtendo como resultado, depois de um ano de trabalho, uma quantidade de produtos que, depois de vendidos no mercado, formam o produto bruto da sua exploração. É desse resultado que ele vai deduzir os custos da produção e só então haverá a renda para trocar por bens materiais para o consumo de sua família. Trata-se de um cálculo impossível de decompor analiticamente e também objetivamente, já que não está imputado nesse valor o custo da força de trabalho utilizada para garantir esse resultado. Com esse objetivo, Chayanov trata de diferenciar a atividade econômica do camponês da de um empresário, e afirma que é impossível aplicar o cálculo capitalista do lucro na atividade camponesa.

En otras palabras, tomamos la motivación de la actividad económica del campesino no como la de un empresario que como resultado de la inversión de su capital recibe la diferencia entre el ingreso bruto y los gastos generales de producción sino más bien como la motivación del obrero por un peculiar sistema de salario a destajo que le permite determinar pos sí mismo el tiempo la intensidad de su trabajo. (Chayanov, 1974, p. 33)

Esse trecho nos remete ao que discutimos no capítulo 4, sobre a produção camponesa. O exemplo do cultivo de milho do Sr. Luiz, quando ele diz que não compensa produzir milho porque dá "prejuízo", dialoga perfeitamente com essa análise. Quando cita esse "suposto prejuízo", ele está se referindo ao cálculo capitalista que, mais adiante, ele próprio descontrói ao explicar que, na verdade, o que prevalece é a relação não capitalista - o que ele está nos apresentando não é o seu ganho e sim o que deixa de gastar durante o ano produzindo o milho.

Podemos encontrar similitudes entre a obra de Chayanov e a de Candido sobre o modo de vida camponês. Em Os parceiros do Rio Bonito, Candido (2010) analisa os meios de vida do camponês, que ele identifica enquanto caipiras, com especial atenção para suas condições

\footnotetext{
${ }^{20}$ Também presenciamos algumas das muitas atividades para além do trabalho com a plantação, como veremos mais adiante.
} 
de vida; a composição da família; a labuta da terra e o tempo livre disponível; as relações sociais que se davam no bairro e na comunidade; a economia baseada em trocas de mercadorias, além da dieta alimentar e da relação com o meio ambiente - todas essas questões tendo como pano de fundo as transformações ocorridas com o avanço do capitalismo.

Em Os parceiros do Rio Bonito, Candido afirma que o local de moradia do camponês depende, sobretudo, de onde estiver localizada a sua roça. Como, em muitos casos, suas casas ficam muito distantes das roças, os camponeses constroem moradias provisórias, os chamados "ranchos". Vale ressaltar que, durante o trabalho de campo em Ribeirão Branco, encontramos camponeses vivendo nesses "ranchos", pois, como não são proprietários de terra, eles arrendam porções de terra que, na maioria das vezes, se encontram em locais mais afastados - únicos locais onde os camponeses conseguem valores acessíveis de arrendamento. ${ }^{21}$

\subsection{Um personagem não compreendido no espaço político}

Martins (1990) afirma que o camponês é um ser particular, não compreendido em relação ao seu lugar na sociedade. O autor afirma que, num certo sentido, ele é um excluído e é nessa condição que os partidos e grupos políticos irão colocá-lo, como um estranho que chega atrasado para o debate político, como um incapaz de fazer história, de definir e atuar no processo histórico, senão no sentido de contê-lo.

Ainda segundo Martins (1990), a história brasileira, mesmo aquela cultivada por alguns setores de esquerda, é uma história urbana: enquanto uma greve na região industrial em São Paulo estimula dúzias de artigos e livros, a Revolta do Formoso, que por mais de uma década, nos anos 1950 e 1960, implantou um território livre dominado por camponeses no centro do país, em Goiás, permanece como assunto esquecido.

A ausência de um conceito, de uma categoria, que o localize socialmente e o defina de modo completo e uniforme constitui exatamente a clara expressão da forma como tem se dado a sua participação nesse processo - alguém que participa como se não fosse essencial, como se não estivesse participando. (MARTINS, 1990, p. 25)

\footnotetext{
${ }^{21}$ Embora tenhamos encontrado camponeses morando em ranchos para ficarem mais próximos da terra (na sua maioria arrendada), é preciso dizer que essa é uma realidade que está se transformando: também encontramos camponeses preocupados, entre outras coisas, em ter uma moradia mais decente para abrigar a sua família. É principalmente uma demanda das mulheres ter água encanada, chuveiro, banheiro dentro de casa, enfim, uma moradia com mais conforto. A esse respeito, vale destacar que nos deparamos com uma forte mobilização pelo acesso à política pública de moradia rural na área pesquisada, por meio do "Programa Minha Casa Minha Vida" do governo federal.
} 
Martins discorre sobre o comportamento dos partidos e do sindicalismo a respeito dos camponeses e afirma que nunca houve de fato um reconhecimento de que esse público pertencesse e fosse importante para as lutas emancipatórias dos trabalhadores. Isso provoca uma reflexão acerca dos espaços de poder nas instituições onde, historicamente, as lideranças camponesas não ocupavam/ocupam cargos de maiores destaques e com poder de decisão, tanto nos partidos políticos quanto nas organizações sindicais e sociais de maiores destaques.

Para Fabrini, a complexidade dos camponeses enquanto sujeitos sociais permitiu a aceitação deles como um sujeito sem projeto de luta de classes.

A dificuldade dos camponeses se situarem politicamente estaria relacionada à sua inserção na sociedade de classes, pois, o camponês não era um operário (proletário) nem um capitalista (burguesia). Numa sociedade de classes divididas entre "escravo e senhor", ou "operário e burguesia", não havia lugar social para o campesinato e a possibilidade de projeção da sua luta. Assim, os camponeses, em vista de sua condição de classe, foram entendidos, como se não tivessem projeto de totalidade. (FABRINI, 2014, p. 70-71)

Acreditamos que diante da diversidade que compõe o campesinato e da falta de compreensão da sociedade para com o seu modo de vida, o que temos é um campesinato chamado apenas para engrossar as fileiras das manifestações populares. No caso de analisarmos as principais organizações de trabalhadores - que reúnem movimentos urbanos e rurais -, não veremos camponeses ocupando cargos importantes. Por exemplo, nunca um camponês presidiu a CUT Nacional ou mesmo assumiu a presidência nacional de um partido de esquerda. Ribeiro diz que:

No século 19, mesmo que os movimentos camponeses tenham sido decisivos em todas as revoluções, conforme apontado por diferentes autores, o movimento operário mais organizado, com maior nível de instrução e com apoio de intelectuais militantes, acabava por esmaecer o papel do campesinato. Destacavam-se, nas análises sobre o campesinato, o seu apego à terra, a sua pouca ou inexistente escolarização, restando-lhe um papel subordinado e fora do âmbito das decisões políticas. (RIBEIRO, 2013, p. 161162)

Não podemos com isso, de modo algum, dizer que os camponeses não se organizam ou não fazem a sua luta. Pelo contrário, eles a fazem através de suas organizações e movimentos específicos; participam das lutas por políticas públicas e pela transformação da sociedade. $\mathrm{O}$ que podemos, sim, afirmar é que eles não ocupam espaços ou cargos com maiores poderes de decisão, como a direção de entidades nacionais que agregam urbanos e rurais - as centrais sindicais, por exemplo -, ou, ainda, não elegem parlamentares que tenham saído diretamente dos movimentos camponeses. 
Os relatos que ouvimos das lideranças camponesas que estão nas cooperativas, sindicatos e partidos políticos apontam a falta formação política. Segundo essas lideranças, a formação política que receberam é fruto do trabalho das Comunidades Eclesiais de Base (CEBs) da igreja católica, que fazia o trabalho de base nas comunidades rurais. Ainda nos foi dito que os partidos políticos, além dos sindicatos, incorporavam e também realizavam o trabalho de formação política de militantes, mas esse trabalho deixou de existir e, agora, as lideranças estão envelhecendo e não encontram oportunidade, como as que tiveram, para formar novas lideranças e continuar o trabalho nas comunidades rurais.

Em relação à sociedade como um todo, o que se nota, a respeito dos camponeses, é uma espécie de estranheza à sua condição, tanto por parte dos setores mais conservadores quanto para alguns setores progressistas. Em uma tentativa de enquadrá-los, o que se faz ainda hoje é manter os camponeses à margem das tomadas de decisões da sociedade.

Retomando a discussão sobre e a lógica camponesa, consideramos importante apresentar alguns dos aspectos, fruto das observações do nosso trabalho de campo, que são estruturais do modo de vida camponês.

\subsection{A troca de produtos}

Durante as visitas que realizamos no trabalho de campo, pudemos presenciar algumas trocas de produtos entre os vizinhos. Na casa do casal Vera e Mauro, eles receberam um cacho de bananas de uma visita. No bairro do Rio Apiaí, enquanto entrevistávamos o Sr. Luiz (da colheita do milho), o seu vizinho, Sr. Luiz Gonzaga, trouxe queijo e leite e levou para a sua casa um cargueiro de milho (aproximadamente $80 \mathrm{~kg}$ ). Perguntamos sobre os valores e eles nos explicaram que cada queijo (de $0,5 \mathrm{~kg}$ ) está sendo vendido por 10 reais e o cargueiro de milho $(80 \mathrm{~kg})$ está sendo vendido na roça por 25 a 30 reais.

O Sr. Luiz Gonzaga nos disse que tinha que garantir o milho nesse período, depois do mês de agosto ele fica muito caro porque os camponeses não vão ter e então ele teria que comprar no mercado. Observamos que ninguém conferiu peso ou mencionou valores, apenas fizeram a troca.

Assinalaríamos, como uma das formas mais recorrentes nos bairros rurais, o costume da partilha dos frutos do trabalho camponês. Produtos da horta e do pomar são frequentemente trocados. Aos vizinhos também são distribuídas partes dos animais de médio e grande porte abatidos. Por fim, a troca também envolve os produtos da lavoura de consumo próprio, o que significa poupar esforços e aumentar a rentabilidade, à medida que destinam áreas maiores a um único produto. [...] Trocam-se mudas e sementes. Trocam-se ovos e emprestam-se galos para melhorar galinheiros que estão "refinando". 
Emprestam-se os melhores cachaços para a fertilização das fêmeas. Emprestam-se touros para evitar problemas genéticos no rebanho. (PAULINO, 2012, p. 384-388)

Durante as visitas nas casas e roças dos camponeses, notamos que essa prática de trocas de produtos é muito comum. Também presenciamos outras trocas, como sabão feito em casa trocado por alguns legumes, e nos informaram que também costumam trocar frango por feijão, alho por amendoim, ervilha por mandioca, ovos por legumes e milho verde por frango, ou seja, coisas que o outro vizinho não tem. Também nos foi relatado que antigamente trocavam farinha feita no monjolo por arroz socado no pilão e carne de porco, de modo que sempre tinham carne em casa.

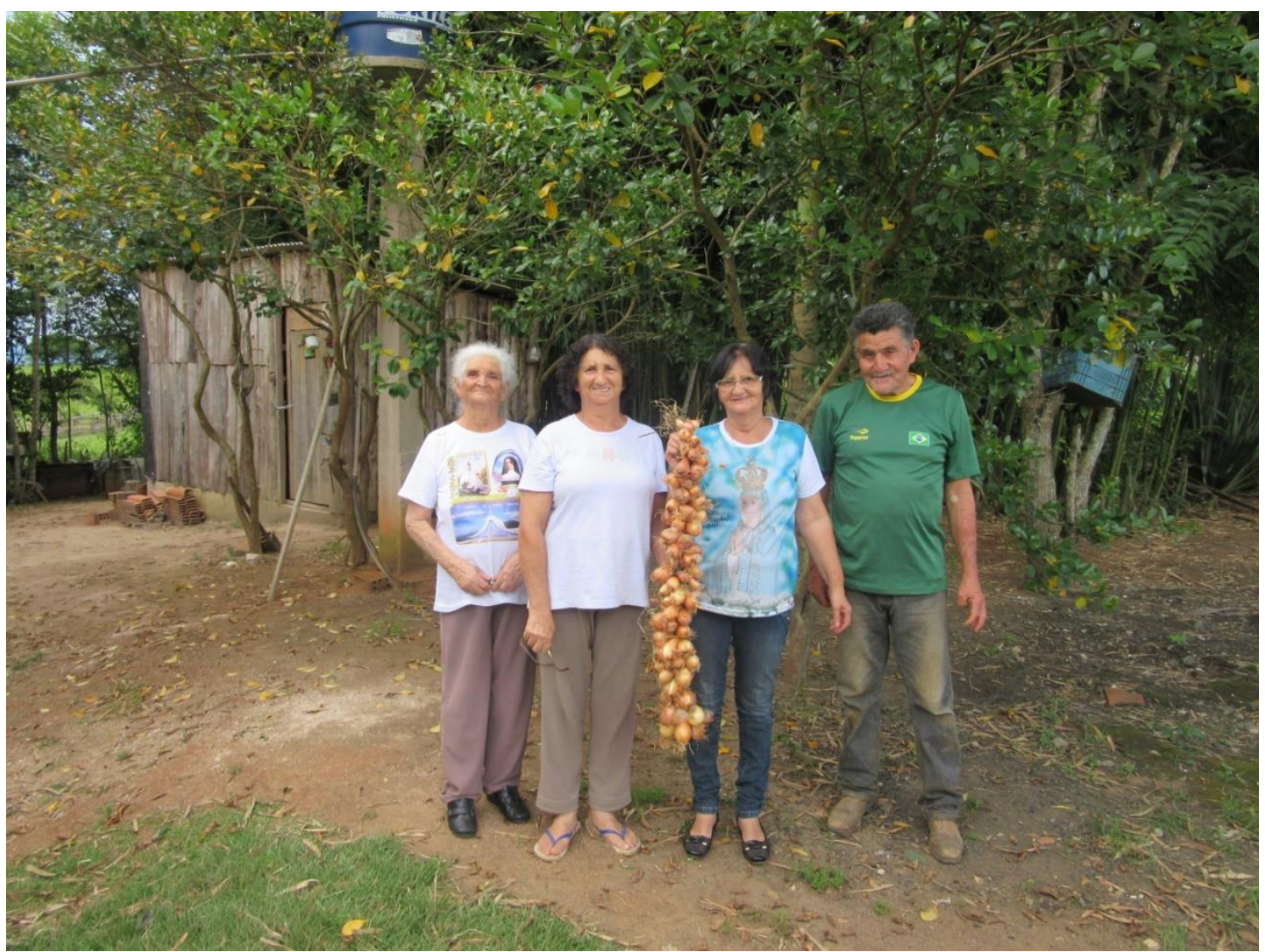

Foto 41: Doação de produtos. Associação dos Agricultores Familiares do Bairro Pocinho, Sítio Freitas, Guapiara. Foto: Lucinei Paes de Lima, jan. 2016.

Podemos observar que, quando se trata de alimento, ele tem um tratamento que não necessariamente é o de mercadoria e existe sempre uma sobra que algum vizinho ou parente distante pode levar.

O elemento central é a comida. Ela tem um valor social grande demais para ser mercadoria. É por seu valor de uso que ela tem valor de troca no contexto 
da reciprocidade, onde dinheiro nenhum tem porque pertence ao domínio do mercado. $\mathrm{O}$ conceito de valor de troca depende, pois, do contexto ao qual se refere. (MOURA, 1978 p. 58)

Na Foto 41, a Sra. Paula, moradora do bairro do Rio Apiaí, faz uma visita à sua irmã Maria Júlia, moradora da Associação dos Agricultores Familiares do Bairro Pocinho no município vizinho, Guapiara, que faz fronteira com Ribeirão Branco. Na volta para a casa, a Sra. Paula levou uma trança de cebola doada pela irmã. Como já destacamos, prática comum entre os camponeses dessa região.

\subsection{A socialização das crianças}

Nas famílias camponesas, todos trabalham, mesmo as crianças e os idosos. No caso das crianças, o trabalho e as responsabilidades com a plantação, a casa, o quintal e os animais vão aumentando com o passar dos anos. Uma das frases que ouvimos durante as entrevistas foi: “trabalho de criança é pouco, mas quem despreza é louco!” O que claramente nos diz que isso faz parte da lógica camponesa. Em Queiroz, encontramos um trecho que discute como seria o aprendizado das crianças:

A educação dada informalmente pela família, por sua vez, apanha as crianças desde o berço e segue pela vida afora, dando-lhes todos os conhecimentos de que necessitam para viver de maneira satisfatória no bairro. É ministrada principalmente através da participação direta e da imitação. As irmãs mais velhas ou as mães ensinam as meninas a costurar, a bordar, a cozinhar, a tratar de crianças. Meninos e meninas aprendem com os pais os trabalhos rurais, quer agrícolas, quer de pecuária. Todo o meio doméstico contribui assim para a socialização da criança. (QUEIROZ, 1973a, p. 60)

O que notamos foi essa realidade, em que as crianças desde muito cedo acompanham os pais e avós para aprender a trabalhar. Em Shanin, vimos que a socialização das crianças realça o caráter tradicional da agricultura camponesa e reforça os laços familiares:

Las habilidades se definen en términos de experiencia transferida directamente o se formalizan en una tradición oral de numerosos proverbios y relatos. La preparación para la ocupación de un campesino se cumple principalmente, dentro de la familia: el joven aprende su trabajo siguiendo a su padre y ayudándolo. Este procedimiento de socialización refuerza los lazos familiares y realza el carácter tradicional de la agricultura campesina. (SHANIN, 1976, p. 19)

Shanin (2008) reforça o processo de socialização das crianças através da imitação dos afazeres dos pais e afirma que uma das características do campesinato é que ele se ocupa de uma série de atividades e nunca só de uma mesma coisa, o que lhe permite ter várias habilidades. 
A verdadeira característica e definição dos camponeses tem como um de seus fundamentos essa natureza especial do campesinato, que nunca é uma coisa só, é sempre uma combinação. Também não é algo que não se aprende na universidade. Só se aprende com os seus pais. Se for um menino, aprende com o seu pai, se for uma menina, aprende com a sua mãe. Como é que o camponês consegue fazer tantas coisas?

Ele acorda com seu pai todos os dias e vai fazendo e aprendendo. É o mesmo para mulheres. (SHANIN, 2008, p. 41)

$\mathrm{Na}$ Foto 42, podemos ver o Sr. Luiz Henrique ensinando os netos a plantar batatas. O processo é iniciado como uma forma de brincadeira em que cada um escolhe a parte que quer cumprir. Nesse caso, um dos três teria que limpar a cova e o outro enfileirar as batatas para depois todos cobrirem juntos.

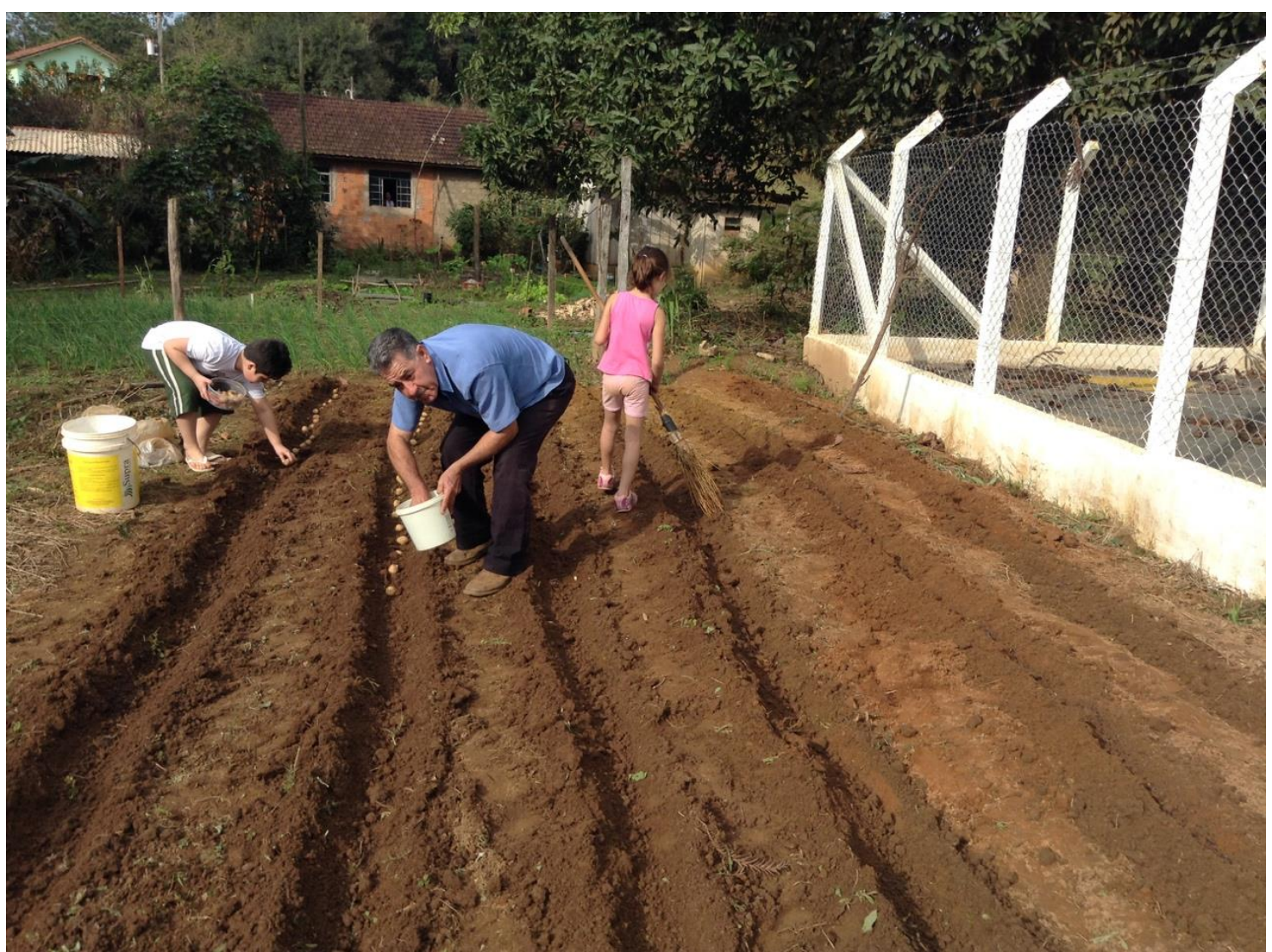

Foto 42: Socialização das crianças na plantação de batatas. Sítio São Luiz, bairro do Rio Apiaí. Foto: Lucinei Paes de Lima, jan. 2015.

Também no bairro do Rio Apiaí, conversamos com a Sra. Maria, que encontramos, com seus 94 anos, limpando o frango que ganhou da vizinha para preparar o almoço da família. Ela nos contou que tem oito filhos e, como é viúva, vive na casa de seus filhos, um pouco na casa de cada um. Nos disse ainda que quando está bem de saúde contribui com os diversos serviços: 
escolher sacas de feijão, trançar cebola e alho (para durarem por mais tempo), limpar frangos para as refeições e lavar louças.

A Sra. Maria nos leva a refletir sobre a lógica da família camponesa em Chayanov (1974), que afirma que essa família tem como característica utilizar do trabalho de todos que podem contribuir com o seu funcionamento.

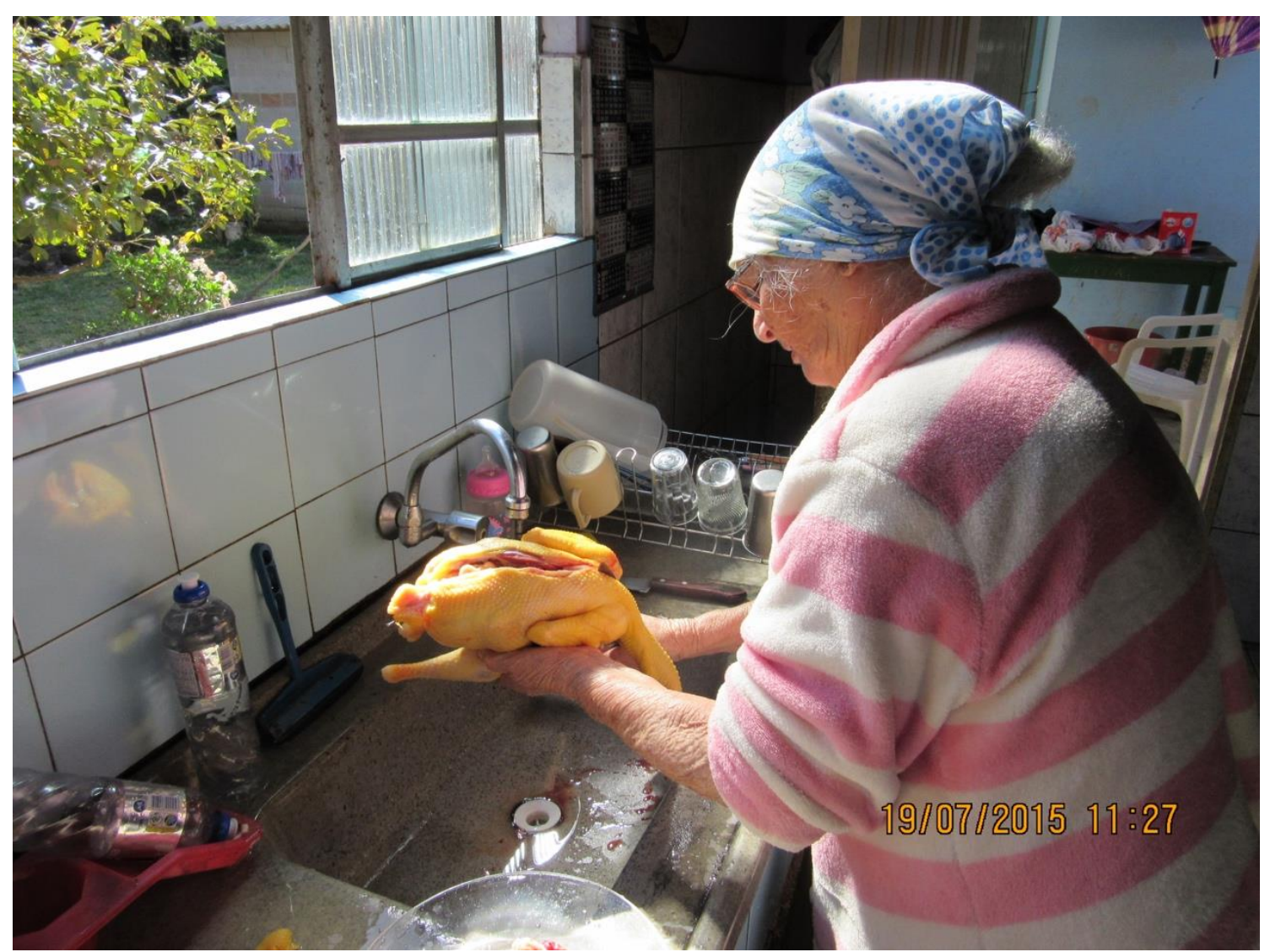

Foto 43: Sra. Maria, de 94 anos, preparando o frango caipira para o almoço. Sítio São Luiz, bairro do Rio Apiaí. Foto: Lucinei Paes de Lima, jul. 2015.

\subsection{O jovem camponês}

Nos diálogos que tivemos com jovens e adolescentes, vimos que, na maioria das vezes, eles executam trabalhos de adultos na propriedade da família e se queixam do cansaço de ter que ir para a escola e também trabalhar. Na perspectiva de algumas famílias camponesas, ouvimos que mandar o filho para a escola significa uma forma de poupá-lo do trabalho árduo da roça. Nesse sentido, a escola é pensada como uma preparação para viver na cidade e ter um trabalho menos cansativo. 
Na contramão desse discurso, entrevistamos a jovem Ana Paula, que reside com a sua família no bairro Coimbra. Ana Paula tem 21 anos de idade e nos contou que fez o ensino médio num colégio agrícola do município de Taquarivaí, e sempre trabalhou com seus pais na roça.

A jovem também nos disse que frequentou a universidade, onde era beneficiária do Programa Universidade para Todos (Prouni), e iniciou o curso de medicina veterinária, mas desistiu no segundo ano. Então, em abril de 2014, decidiu sair da roça e ir para a cidade de Sorocaba, onde trabalhou em uma lanchonete da rede McDonald's.

Sete meses depois, em novembro de 2014, ela retornou e decidiu plantar tomates sozinha, ter uma roça só dela. Fomos até a sua plantação de 3 mil pés de tomate, onde ela nos contou que trabalhava sozinha diariamente, mas, esporadicamente, aos finais de semana, pode contar com a força de trabalho de seus pais - que trabalham na prefeitura municipal e, nos horários fora do expediente da prefeitura, na roça. Sua mãe transporta alunos da área rural e o pai está Secretário Municipal de Agricultura do município.

Ana Paula voltou para a faculdade e escolheu o curso de Agronomia para cursar. Perguntamos se gostava de trabalhar no campo e, como já havia experimentado a vida na cidade grande, como ela se sentia e quais eram seus planos. E ela nos deu a seguinte resposta:

Ah, morar no sítio é mais sossegado, não tem ninguém mandando em você, é a gente que faz os horários, não precisa acordar cedo.

Eu trabalho porque a gente quer ter o dinheiro da gente, eu estou trabalhando para ter as minhas coisas. Quero ter um celular bacana, comprar roupas e também quero comprar uma moto nova para mim e também quero ter a minha casa mesmo.

Eu faço agronomia porque já fiz o técnico agrícola e quero dar continuidade aos estudos.

Depois de formada quero ficar por aqui mesmo, dar assistência técnica e ajudar o povo aqui do bairro. (Entrevista com Ana Paula, mar. 2015)

Acreditamos que a experiência de morar e trabalhar na cidade levou Ana Paula a valorizar ainda mais o trabalho camponês. A possibilidade de "decidir" o trabalho que irá fazer no dia a dia e os horários flexíveis é tida como um privilégio. É comum encontrar, em um bairro camponês, alguém que já tenha tentado a vida na cidade, mas que não conseguiu se adaptar ao modo de trabalho e tenha retornado para junto da família na propriedade camponesa.

Ana Paula fez o caminho de volta para o campo. Perguntamos sobre os motivos que a levaram a ir para a cidade e ela nos contou que principalmente a curiosidade por conhecer uma realidade diferente e a busca por lazer e entretenimento. Essa reflexão podemos ver em Shanin a respeito do jovem camponês:

A maioria das pessoas que vão para a cidade são pessoas jovens, que não estão necessariamente procurando um trabalho mais leve. Eles estão geralmente em 
busca de cinema, das luzes da cidade grande, de uma vida mais interessante que a cidade pode oferecer em lugar da vila. Então, mais uma vez, não se trata de uma questão de simples resposta. As pessoas migram por vários motivos e não muito frequentemente por causa de trabalho ou de renda, mas, por muitas outras razões.

O trabalho camponês pode ser extremamente duro, dependendo da cultura, dos diferentes tipos de agricultura e também das estações do ano. Algumas pessoas preferem o trabalho agrícola, outras, odeiam esse tipo de trabalho. Neste sentido, enquanto houver essa situação e enquanto houver campesinato, algumas pessoas vão continuar a sair do campo para a cidade e eles devem ser apoiados em sua decisão. Eu não vejo nada errado nisso, porque as pessoas devem ter a liberdade de encontrar o melhor lugar para elas. E, se elas quiserem ficar e acharem a cidade interessante, esse direito deve ser defendido. Eles também têm direito à mudança.

Mas, as dificuldades da vida agrícola têm mudado por causa da mecanização. Agora, o trabalho de muitos camponeses é fundamentalmente mecanizado. Então, a necessidade de realizar um esforço grande é menor. Mesmo assim, isso não acontece em todos os lugares, há variações etc. Alguns jovens, mesmo apresentando boa escolaridade, preferem ficar nas vilas por motivos próprios. (SHANIN, 2008. p. 39)

Segundo os relatos que ouvimos, um dos motivos que levam os jovens camponeses a saírem da propriedade da família é o fato de o pai tomar as decisões e não as compartilhar com os filhos, como podemos ver no depoimento do Sr. Luiz Pacheco, do bairro da Cachoeira:

A gente erra que nem nosso pai errou de não conversar das coisas, do que vão fazê para plantar, do que vai fazê com o dinheiro que sobrou. Os filhos querem fazê as coisinhas deles e a gente às vezes não deixa. Eles querem ter a conta no banco, eles querem ter uma moto para passear e aí ele olha pra cidade e vê que pode ganhar um salário lá e se anima. E a escola também não ajuda, eles vão pra escola e lá eles não ensina valorizar as coisa da roça. A escola ensina que a roça é coisa de gente atrasada. (Entrevista com Luiz Pacheco, mar. 2015)

Esse assunto é fundamental para buscarmos compreender a condição do jovem camponês, seus desafios e expectativas. As principais reivindicações relatadas foram a falta de acesso à educação superior, de políticas públicas específicas de incentivo para a sua produção, de assistência técnica e de áreas de esporte e lazer.

Por outro lado, vem à tona nessa discussão o papel da escola e da educação no campo, reconhecendo que esse debate precisa ser expandido no sentido de defender que a educação no campo deve ser efetivada e elaborada a partir das especificações do modo de vida camponês. 


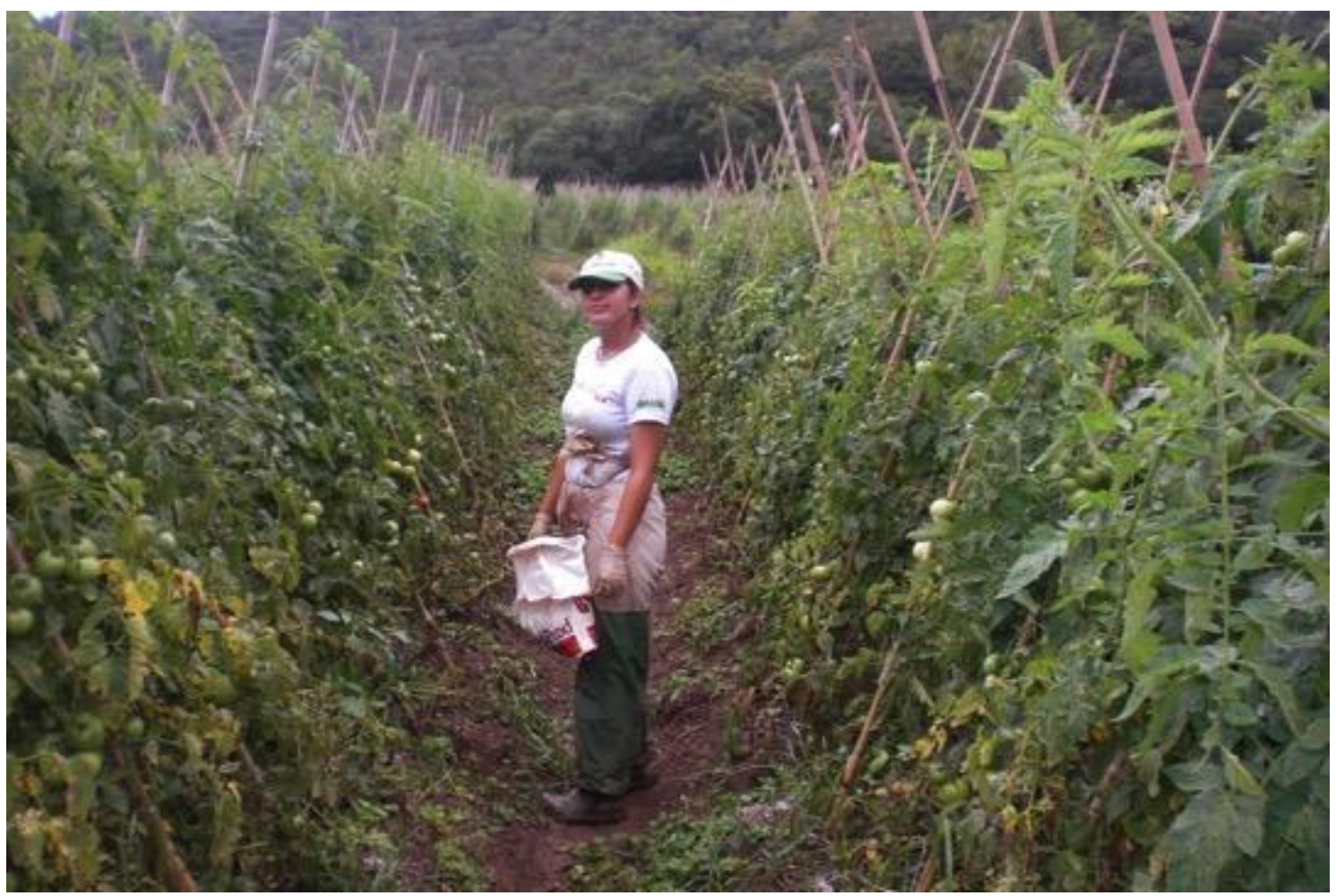

Foto 44: Ana Paula, de 21 anos, em sua roça de tomates. Associação dos Produtores da Microbacia do Rio Apiaí Guaçu - Banco da Terra, bairro Coimbra.

Foto: Lucinei Paes de Lima, mar. 2015.

Finalizar este capítulo com o debate sobre a juventude camponesa nos enche de estímulos para continuarmos a estudar o campesinato. O que vimos até agora é que, em Ribeirão Branco, os camponeses estão ativos e se recriando. O capítulo seguinte caminha nessa direção, da recriação camponesa, e lança um olhar sobre sua cultura, explorando a forma como o camponês interage e exerce a sua "vida de bairro". 


\section{Vida de bairro}

Diferentemente do entendimento corrente sobre Bairro Rural, em que este é interpretado de maneira isolada, pois o entendimento tradicional de campesinato é também aquele que envolve uma certa parcela de isolamento, proponho a compreensão do Bairro Rural como uma unidade territorial criada a partir da identidade territorial, e, o que é fundamental, se reproduzindo no interior do capitalismo. Esta unidade territorial forjada pelo trabalho camponês ganha uma configuração que difere diametralmente daquela em que as relações tipicamente capitalistas é que dão a configuração ao território, ou seja, onde temos a territorializacão do capital. A unidade territorial (bairro rural) é, desta forma, fruto da identidade territorial criada a partir da sociabilidade camponesa. É a teia de relações estabelecida entre as famílias camponesas que dá ao grupo sua identidade, esta por sua vez, se materializa no território, dando a este a dimensão peculiar do Bairro Rural. Esta interpretação do bairro rural nos permite, portanto, abarcar, compreender e lançar luz sobre o lugar do campesinato e de sua reprodução nesta sociedade. (BOMBARDI, 2004, p. 55)

Durante o trabalho de campo pudemos observar algumas características comuns de serem encontradas nos bairros rurais de Ribeirão Branco. São características importantes para a vida desses camponeses, constituídas, na sua maior parte, por espaços de encontros onde depositam o seu tempo livre: a igreja, o campo de futebol, a venda, o jogo de cartas, as cavalgadas. Bombardi, a esse respeito, destaca que o bairro é o resultado da articulação das unidades camponesas ali existente:

Assim, o bairro não é a soma de sítios, mas a relação que se estabelece entre essas diferentes unidades camponesas e delas com a escola, com a venda, com o centro comunitário etc.

Dessa forma, o bairro rural se configura como uma unidade territorial geográfica - a partir da identidade territorial -, num entendimento de que se caracteriza como uma fração do território (diferente daquela produzida diretamente pelo capitalismo) que é resultado da articulação das unidades camponesas, que por sua vez, são determinadas pela liberdade e autonomia camponesas via o controle do tempo e do espaço, não só o de moradia, como e, sobretudo, o de trabalho.

A especificidade do campesinato como classe social portadora de uma ordem moral, que se opõe à ordem econômica, é que permite a existência do bairro rural, desta unidade/identidade territorial. (BOMBARDI, 2004, p. 62)

Segundo Candido (2010), os bairros rurais representavam as instâncias de maior sociabilização do camponês: os bairros eram os agrupamentos de pessoas que sentiam uma forma de pertencimento àquela localidade e, entre os principais modos de sociabilização, estavam a religião e as formas de trocas e de ajuda mútua entre os familiares e vizinhos. Para Candido (2010), a vida religiosa, em especial o fato de ter de ir à missa na capela central todos os domingos, representava o contato externo com as outras famílias do bairro. 
Em relação aos bairros rurais do estado de São Paulo, Bombardi acrescenta:

Em São Paulo, a essa unidade territorial camponesa, formada a partir da relação entre as unidades territoriais familiares (os sítios), chamamos bairro rural.

Qual a sua unidade de agrupamento? A freguesia, no conjunto, centralizada pelo que se costumava chamar de sua 'capital'? Não, certamente; mas sim aquelas unidades fundamentais referidas mais altas: os grupos rurais de vizinhança, que na área paulista se chamaram sempre bairro.

Este é a estrutura fundamental da sociabilidade caipira, consistindo no agrupamento de algumas ou muitas famílias, mais ou menos vinculadas pelo sentimento de localidade, pela convivência, pelas práticas de auxílio mútuo e pelas atividades lúdico-religiosas. (BOMBARDI, 2004, p. 59)

Essa análise de Bombardi nos permitiu olhar para o bairro rural como um universo a ser desvendado e motivou as nossas observações durante o trabalho de campo, nas visitas e nas entrevistas com camponeses, e também com o representante da paróquia de Ribeirão Branco.

\subsection{A vida religiosa}

Em Ribeirão Branco, ao visitarmos um bairro rural, por certo encontraremos uma capela determinando o lugar em que ocorrem os encontros rotineiros entre os moradores. Esses encontros costumam ser mais frequentes durante o inverno, quando o trabalho é menos intenso - o que não significa que durante o período de safra os camponeses não se dediquem a vida religiosa e de bairro. Na safra, devido à maior intensidade de trabalho, os encontros apenas acontecem com menos frequência. Em seu trabalho sobre os colonos produtores de uva no sul do Brasil, Santos (1978) fala sobre a importância da sociabilidade e sobre os períodos de maior ou menor intensidade de trabalho dos camponeses:

Outra instituição da sociabilidade dos camponeses é o lazer comum. Nas noites de inverno, principalmente, quando o ciclo da parreira requer menos cuidados e as jornadas são mais curtas, várias famílias se reúnem em uma casa, fazendo serão [...]. Geralmente, à exceção da época da colheita da uva, as pessoas trabalham até sábado ao meio-dia e depois saem de casa. [...] Mas ir à missa é também a oportunidade de encontrar-se com amigos e parentes distantes, conversar, e, traço constante de todas as reuniões, ocasião de trocar informações sobre os negócios da uva e do vinho.

Entre as formas de sociabilidade, há ainda a "festa do padroeiro", realizada no próprio bairro rural, no mês de outubro, e totalmente organizada em comum pelos habitantes do bairro rural. (SANTOS, 1978, p. 159-160)

Não por acaso, é também no período do inverno que, em Ribeirão Branco, acontecem as principais festas religiosas, tais como a do Divino Espírito Santo e a do padroeiro da cidade, Senhor Bom Jesus. 
A Igreja matriz realiza três festas durante o ano e são essas festas que promovem os maiores encontros entre os bairros rurais do município: a Festa do Divino Espírito Santo, que acontece no mês de comemoração ao dia de Pentecostes; a Festa do Padroeiro do município, Senhor Bom Jesus, que acontece no mês de agosto; e a Festa de Nossa Senhora da Conceição, que ocorre no mês de dezembro. Todas as festas são realizadas a partir da dinâmica empenhada pelas comunidades dos bairros rurais que arrecadam as prendas, vendem as cartelas de prêmios do bingo e divulgam o calendário em suas comunidades. Desse modo, a religiosidade é inerente a vida camponesa. Como explica Bombardi:

A religiosidade é o pano de fundo da vida camponesa. Ela rege os padrões de conduta e chega mesmo a imprimir-se de tal forma que por vezes funciona até mesmo como uma ferramenta (técnica) de que lançam mão nos momentos adversos, por meio de rezas, promessas e benzeduras.

Nos bairros rurais o local do culto religioso é a capela, que em geral está localizada na área central. (BOMBARDI, 2004, p. 75)

Da Foto 45 a Foto 48, estão algumas capelas dos bairros que visitamos. Podemos observar que existe sempre um barracão ao lado da capela, utilizado nos dias de festa e onde acontece o bingo, a venda de assados e o baile.

$\mathrm{Na}$ Foto 48, podemos observar, ao lado da capela do bairro da Boa Vista, a imagem de uma escola rural que, segundo os moradores, foi desativada por falta de alunos. Esse bairro fica num lugar chamado pelos camponeses de "sertão" justamente por ser o bairro mais isolado do município. Os camponeses nos disseram que sofrem com a falta de estradas e de transporte para a sede municipal. 


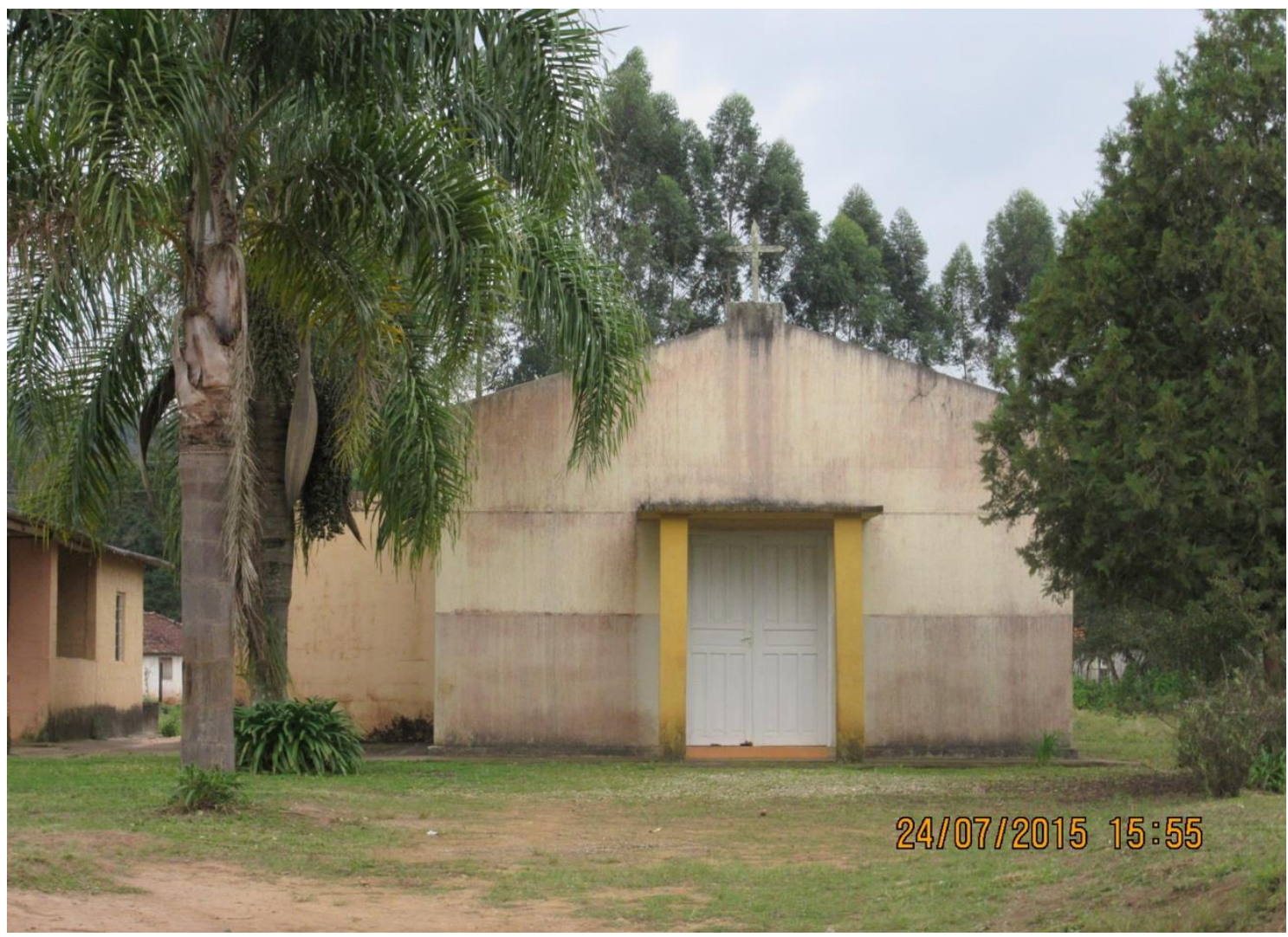

Foto 45: Capela do bairro dos Marques, que tem como padroeiro São Sebastião. À direita está o salão para realização das festas. Foto: Lucinei Paes de Lima, jul. 2015.

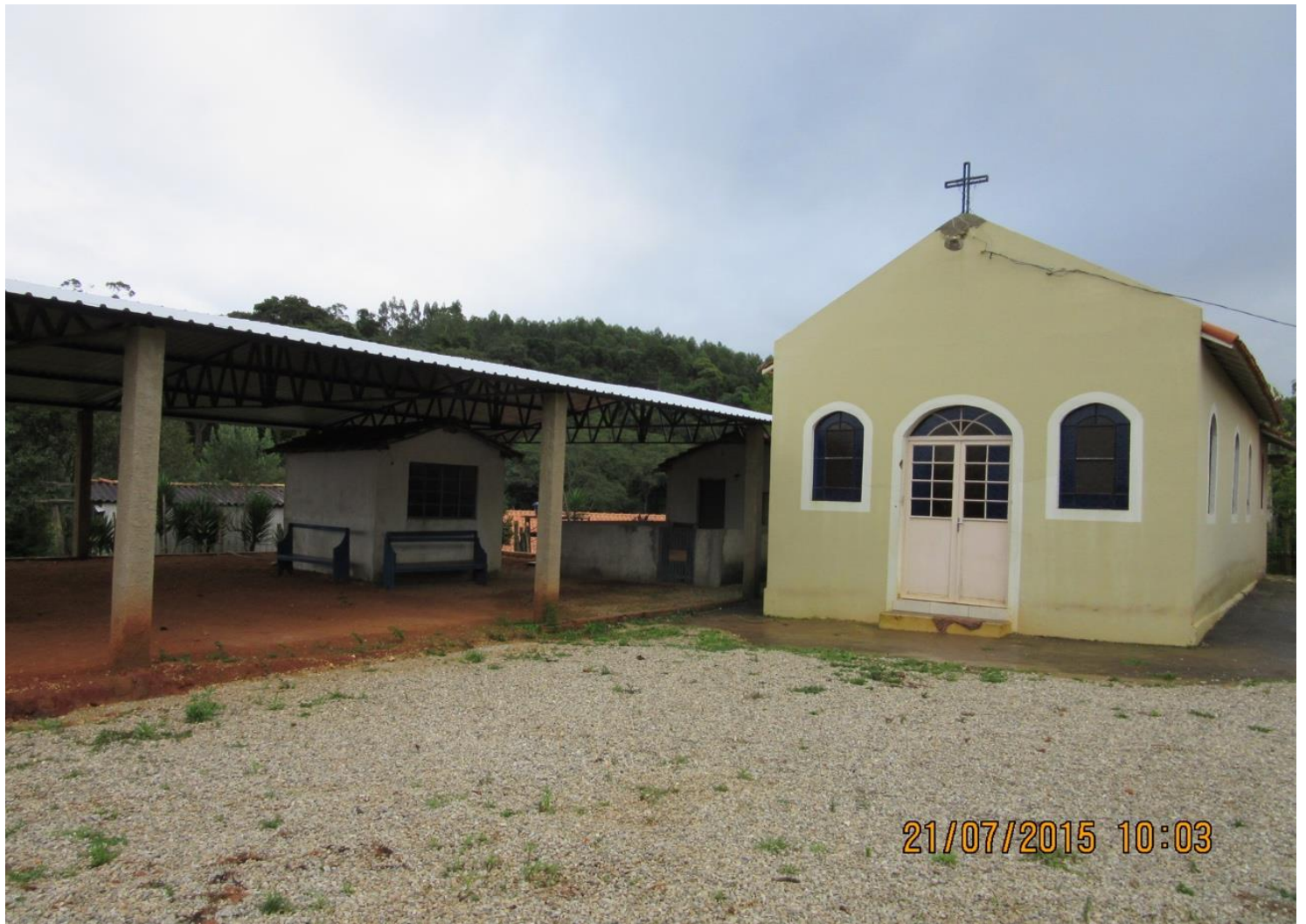

Foto 46: Capela do bairro dos Boavas, que tem como padroeira Nossa Senhora Aparecida. À esquerda, o salão de festas. Foto: Lucinei Paes de Lima, jul. 2015. 


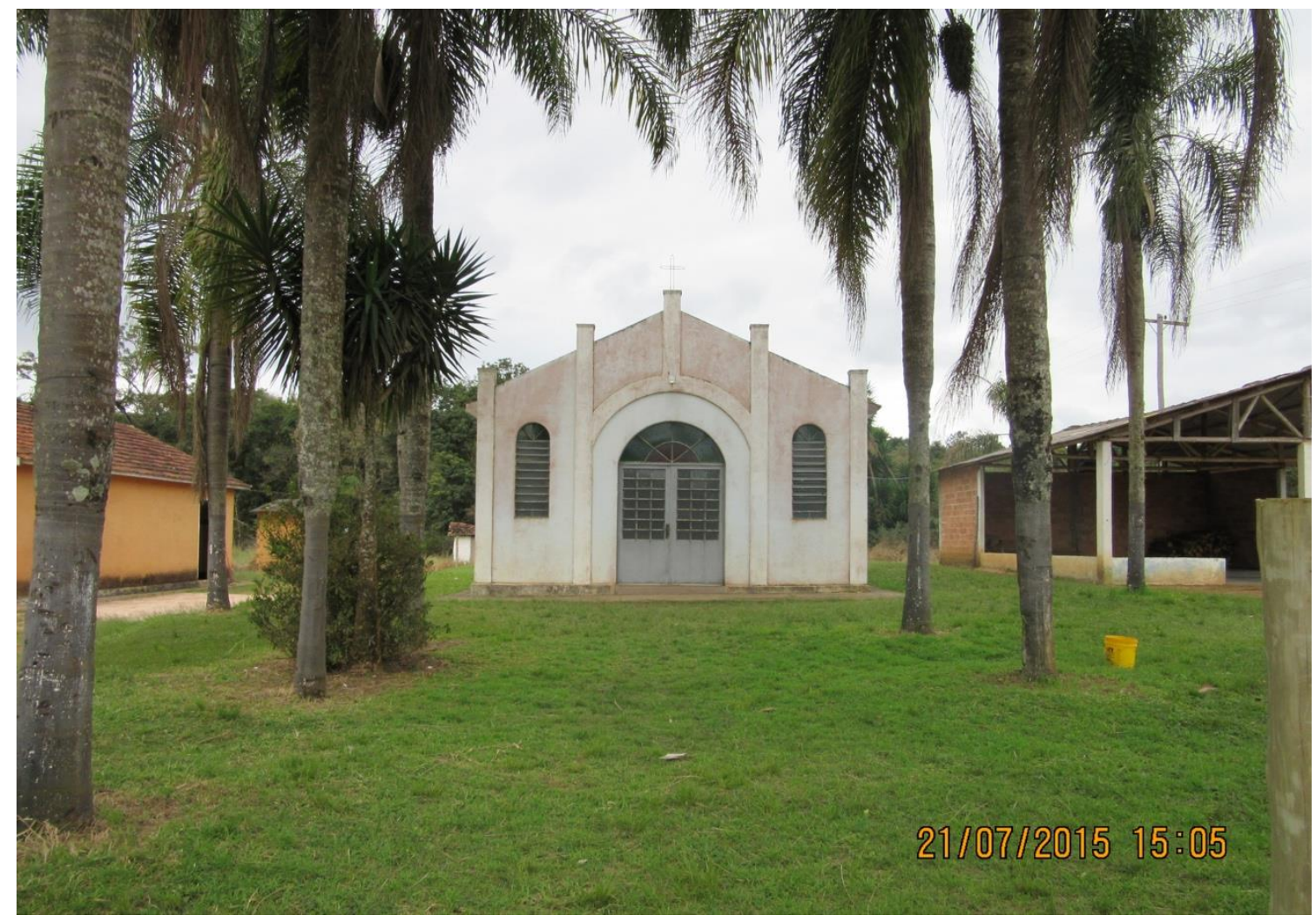

Foto 47: Capela do bairro do Rio Apiaí, que tem como padroeiros Santa Rosa de Lima e São Paulo Apóstolo. À esquerda, a cozinha para os preparativos e, à direita, o salão de festas. Foto: Lucinei Paes de Lima, jul. 2015.

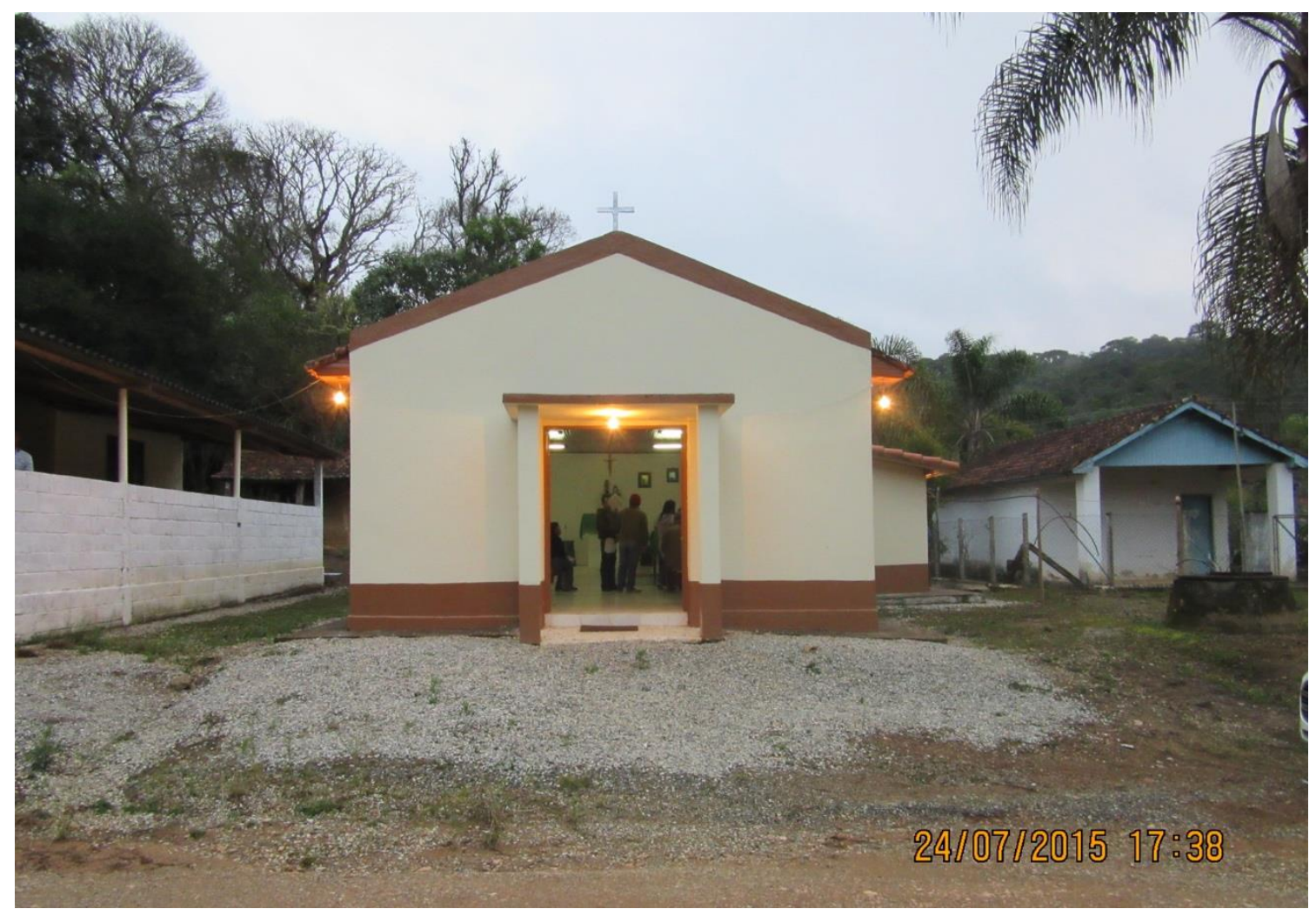

Foto 48: Capela do bairro da Boa Vista, que tem como padroeiros São Miguel e São Domingos. À esquerda, o salão de festas; à direita, a escola desativada por falta de alunos. Foto: Lucinei Paes de Lima, jul. 2015. 
A dificuldade de deslocamento para a parte urbana do município fez com que muitas famílias buscassem lugares mais próximos de serviços como escolas, médicos e bens de consumo para se reinstalarem. A imagem da escola abandonada ganha importância quando moradores do bairro nos narram que, no momento da nossa visita, existiam somente três crianças em idade escolar residindo ali. Diante disso, essas crianças são transportadas para estudar em outros bairros, mas, por conta das condições precárias da estrada, quando chove ninguém consegue se deslocar e elas ficam sem aula. $\mathrm{O}$ fechamento da escola é contado com tristeza pelos camponeses, eles relatam com saudades do tempo em que crianças corriam por ali. Isso confirma as considerações feitas por Paulino:

[...] o empenho em manter a escola viva é também uma forma de assegurar que os valores camponeses sejam perpetuados e, com eles, a própria comunidade. Aquelas que tiveram as suas escolas fechadas veem com preocupação o envio das crianças para a cidade. (PAULINO, 2012, p. 367)

A escola do bairro do Rio Apiaí (Foto 49) é uma das que recebe alunos do bairro da Boa Vista. No momento da nossa visita, eram os alunos do primeiro ano do ensino fundamental que a frequentavam.

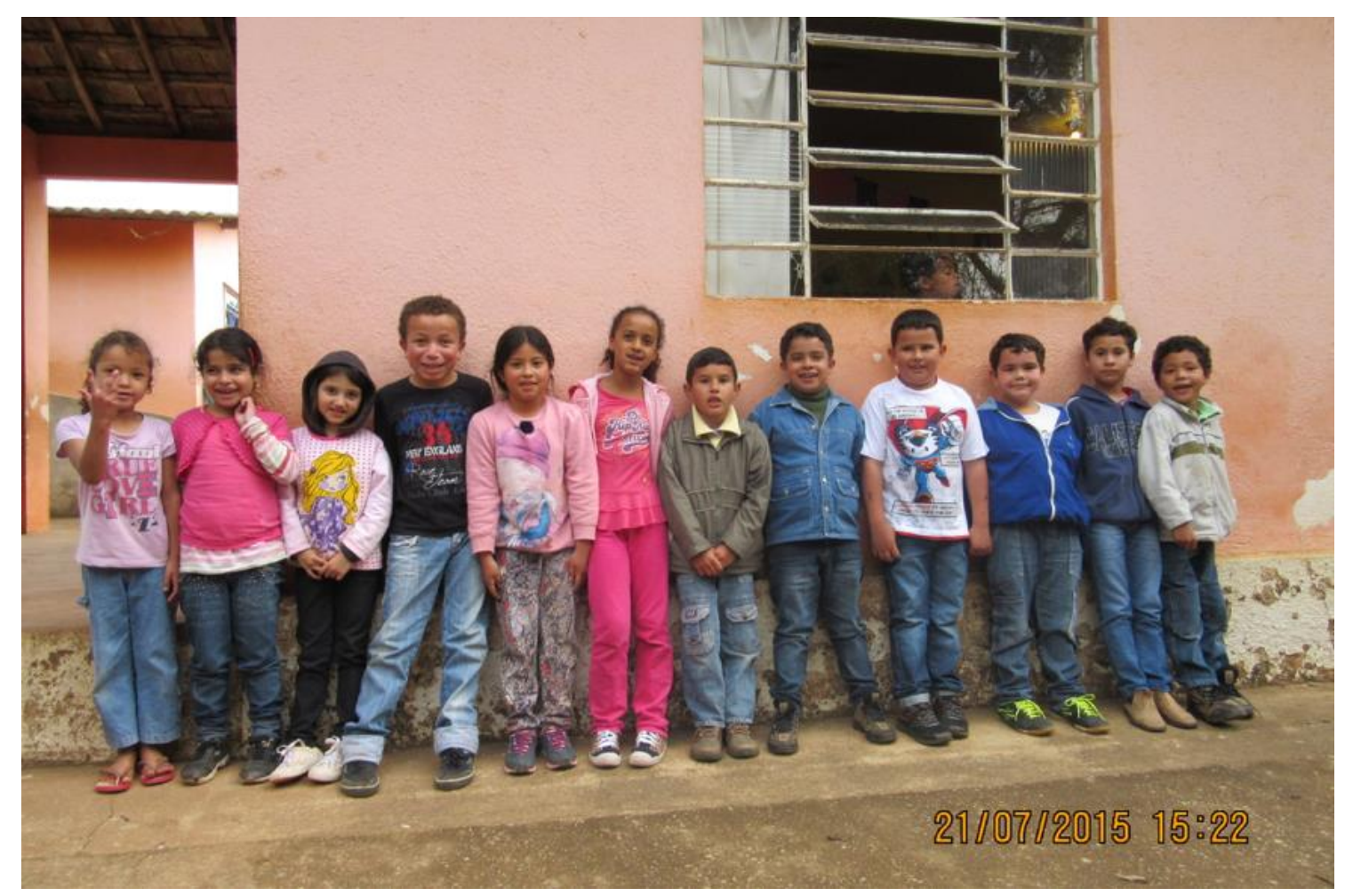

Foto 49: Escola rural do bairro do Rio Apiaí. Alunos da primeira série ensino fundamental. Foto: Lucinei Paes de Lima, jul. 2015. 
O município de Ribeirão Branco, como já tratamos, tem um calendário de festividades religiosas que se caracterizam como ponto de encontro e confraternização dos bairros rurais. É sobre essas festas iremos tratar a seguir.

\subsection{A festa do Divino Espírito Santo}

Segundo Queiroz (1973a), as festas religiosas constituem a atividade recreativa por excelência dos camponeses e o pretexto para os moradores do bairro se encontrarem regularmente, reunindo-se também com os habitantes de outros bairros mais distantes.

O fato de comparecerem a cerimônias religiosas na sede do município, a centros como Aparecida do Norte etc., contribui para dar-lhes o sentimento de pertencerem ao seu bairro, mostrando-lhes a localidade em que se situam e as peculiaridades de seu grupo de vizinhança; mas também indica que o bairro pertence a algo de mais amplo do que o município - a uma religião. A religião reforça a solidariedade interna do bairro, mas serve também para quebrar-lhe o isolamento, ligando-o com uma sociedade mais vasta que o engloba. (QUEIROZ, 1973a, p. 64-65)

Em Ribeirão Branco, as famílias se organizam para irem juntas às festas nos bairros vizinhos e também para Aparecida do Norte - viagem que procuram fazer ao menos uma vez ao ano. Para a viagem até Aparecida do Norte, todos se mobilizam para vender o total de vagas do ônibus. Todos querem ir acompanhados de seus parentes e amigos mais próximos, nos disseram que até dividem o lanche durante a viagem.

Sobre as festividades religiosas, as consideradas mais importantes e que reúnem todas as comunidades rurais são realizadas no centro da cidade, onde está a igreja matriz (Foto 50).

Pudemos acompanhar algumas atividades religiosas durante o trabalho de campo. Nosso primeiro contato foi com a festa do Divino Espírito Santo. Fizemos a caminhada da bandeira do Divino no bairro do Rio Apiaí, uma oportunidade de dialogar com os camponeses e, ao mesmo tempo, fazer parte de um momento fundamental para eles: a peregrinação que dá início à maior festa do município. Sobre a origem dessa festa, Mariano nos explica que:

A festa do Divino Espírito Santo mantém, no Brasil, alguns elementos que já estavam, no século XIV, cristalizados em Portugal. Uma das figuras mais importantes é a do Imperador do Divino que, atualmente, em alguns locais, foi substituído pelos chamados Festeiros, os responsáveis pela realização da Festa. (MARIANO, 2007, p. 51) 


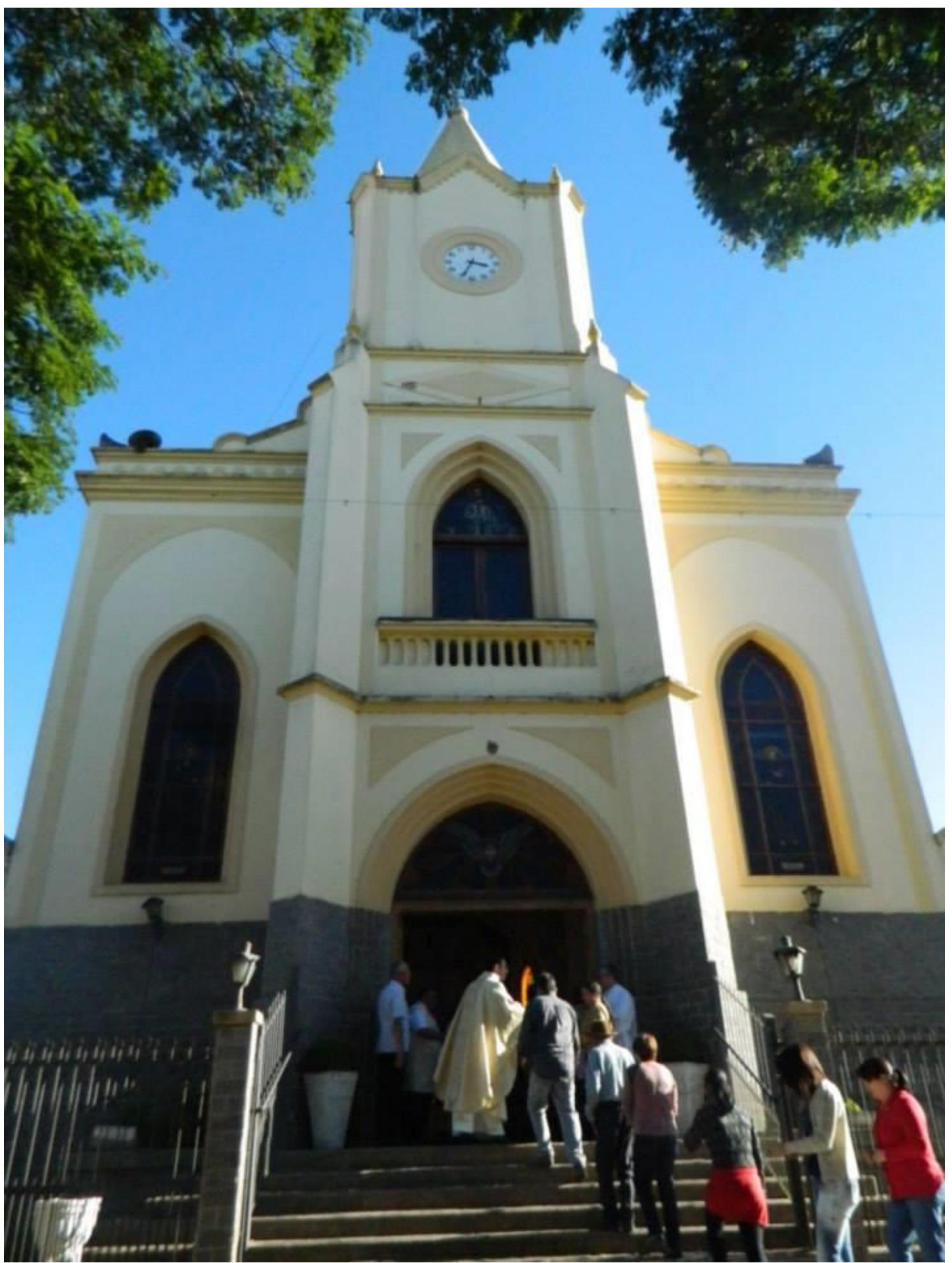

Foto 50: Fachada da Igreja matriz de Ribeirão Branco. Foto: Arquivo pessoal do Padre Cícero. 


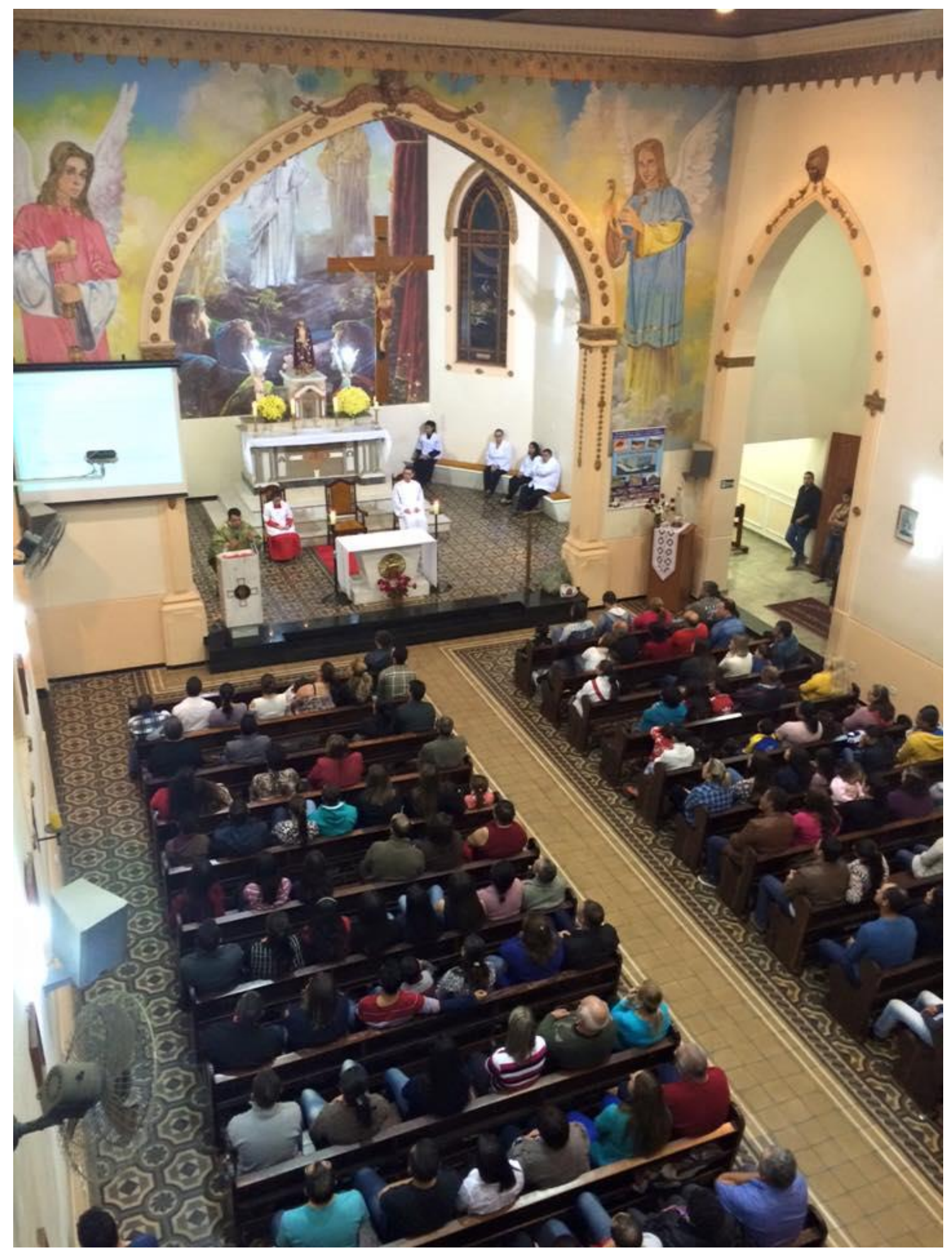

Foto 51: Imagem interna da Igreja matriz de Ribeirão Branco. Foto: Arquivo pessoal do Padre Cícero. 
E acrescenta:

A folia do Divino compõe o cenário da Festa atuando, porém, antes mesmo do período da festa. Costume português, a Folia do Divino do Rio de Janeiro do século XIX, descrita por Abreu (1999) ${ }^{22}$, constituía-se por um grupo que carregava a bandeira do Divino em peregrinação, e a oferecia às pessoas para beijarem e passarem pelo corpo, com o objetivo de cura de alguma enfermidade; em troca, a Folia recebia uma ajuda em espécie (verduras, frutas, ovos, animais etc.) ou em dinheiro. Em alguns momentos, a folia era agraciada com refeição e pousada, oferecidas principalmente pelos moradores da zona rural, devido às longas distâncias entre um sítio e outro. Tudo o que a Folia arrecadava era para ajudar os festeiros, ou seja, a família do Imperador para a realização da Festa do Divino. (MARIANO, 2007, p. 53)

Assim como analisado por Mariano, durante a peregrinação da bandeira do Divino Espírito Santo em Ribeirão Branco, observamos que algumas pessoas caminhavam ao encontro da bandeira, a beijavam e passavam pelo corpo e faziam o sinal da cruz.

Os habitantes das casas que recebiam a bandeira do Divino doaram frangos e também dinheiro e, em algumas moradias, foi oferecido um café acompanhado de bolachas, pão e bolo no fim das orações. A "Caminhada da bandeira" é muito animada, as canções são acompanhadas com violão e pandeiros, e os cantadores entoam diversas músicas.

O objetivo de cada comunidade rural durante a peregrinação é percorrer todas as moradias das famílias católicas do bairro. Alguns participantes nos contaram que existem algumas famílias que nunca vão à igreja, mas que pedem a visita da bandeira para abençoar as suas casas mesmo assim. Segundo Queiroz (1973b), essa é uma forma de se sentir parte do grupo; doar a prenda para a festa significa não ficar à margem do bairro e sim marcar o seu pertencimento a ele.

O caminho percorrido retraça os contornos do bairro. Com suas oferendas, as famílias marcam a integração a ele: uma galinha, um leitãozinho, espigas de milho, um saco de farinha de mandioca, de que se privam em favor da festa coletiva. Nada a ofertar significa querer ficar à margem do grupo; a participação econômica, muito mais do que a presença à festa, marca o fato de se pertencer ao bairro. (QUEIROZ, 1973b, p. 58)

A peregrinação da bandeira do Divino ocorre no período que marca o final da safra agrícola do município, principalmente a do tomate. A caminhada da bandeira tem como data de referência a Páscoa, domingo em que a igreja matriz convoca todas as comunidades para retirarem as suas bandeiras e darem início à preparação da festa. Depois dessa data, as comunidades terão cinquenta dias para percorer as moradias dos bairros rurais - a festa coincide

\footnotetext{
${ }^{22}$ ABREU, Marta. O Império do Divino: festas religiosas e cultura popular no Rio de Janeiro, 1830-1900. Rio de Janeiro: Nova Fronteira; São Paulo: Fapesp, 1999.
} 
com o dia de Pentecostes. É comum, nesse período, encontrarmos pelas estradas dos bairros uma procissão com famílias inteiras caminhando atrás da bandeira do Divino. Nem o frio e a escuridão impedem a presença marcante de crianças e idosos que acompanham toda a caminhada.

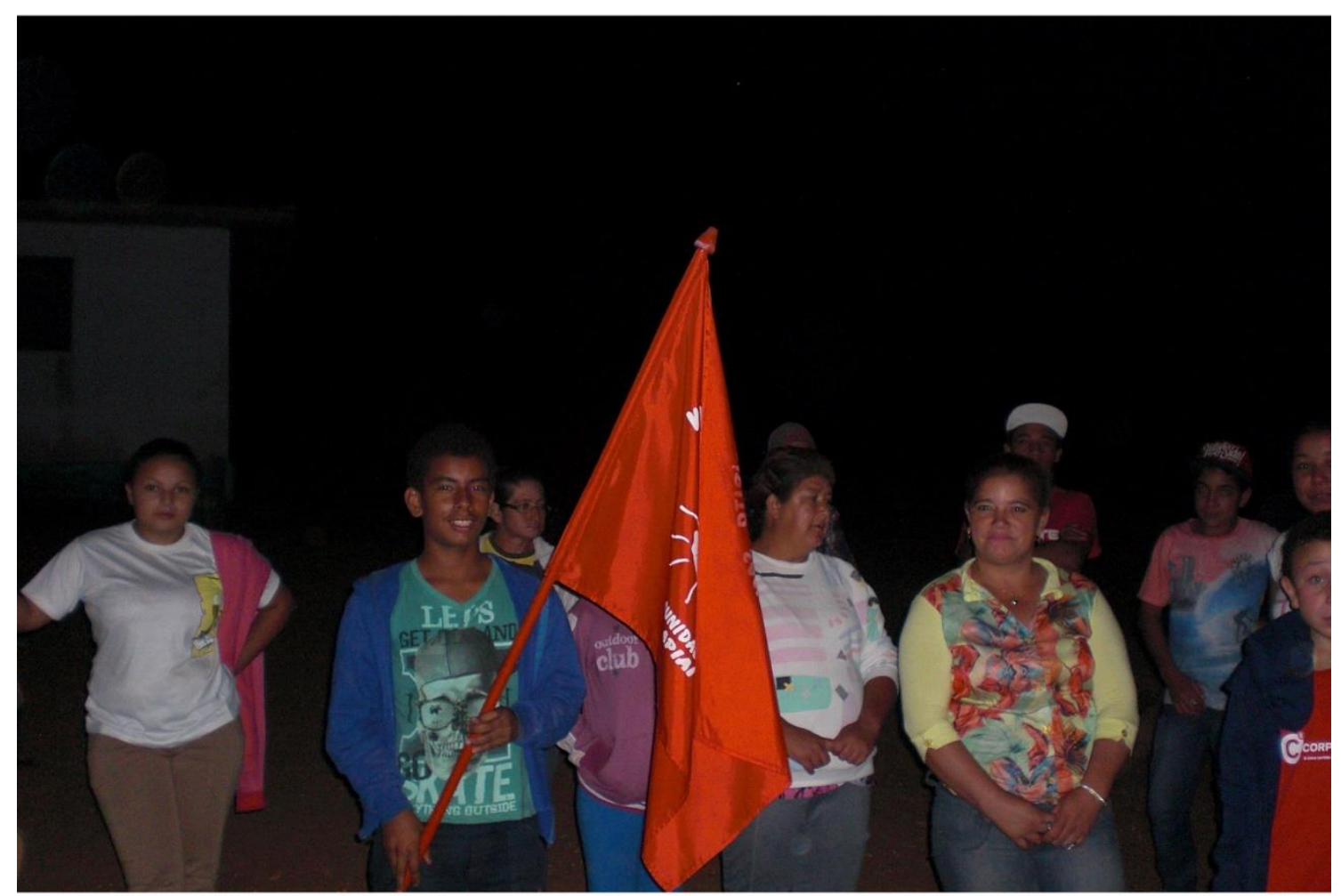

Foto 52: Jovens na concentração para a caminhada da bandeira do Divino no bairro do Rio Apiaí. Eles cantam e leem as orações durante a peregrinação. Foto: Lucinei Paes de Lima, abr. 2015.

O procedimento é igual em todas as residências. Os participantes chegam às casas cantando e a família aguarda em frente à sua moradia com as portas abertas. Os participantes adentram a casa, rezam, cantam novamente e finalizam pedindo a prenda e realizando a coleta de dinheiro. A família que recebeu a visita deve carregar a bandeira até a casa do próximo vizinho, e assim por diante ${ }^{23}$. O dono da casa percorre todos os cômodos com a bandeira pedindo a proteção e, só depois, volta e recebe a todos para iniciar as orações. Durante toda a reza a bandeira permanece nas mãos dos donos da casa.

A Figura 16 mostra partes do folheto utilizado para a reza nas moradias.

\footnotetext{
${ }^{23}$ A cada dia eles percorrem uma determinada distância e um número de casas até que decidem parar e agendam a próxima caminhada. Quando uma casa é muito distante, geralmente marcam um dia só para ir até ela. Quando há um número de casas mais próximas, realizam o máximo de visitas que puderem para aproveitar o tempo e cumprir o calendário até a Festa do Divino.
} 


\section{A VISITA DA BANDEIRA}

Mais uma vez nossas comunidades iniciam as visitas da Bandeira do Divino Espirito Santo. Durante o tempo Pascal, isto é, até a Festa de Pentecostes, os grupos de Folia do Divino, percorrem as comunidades levando a Bandeira, que vai de casa em casa, para pedir proteçào e a ajuda do Espírito Santo para as famílias que a recebem de coração aberto.

As ofertas que são colocadas para o Divino, lembram que devemos ser agradecidos a Deus pelos Benefícios que Ele nos oferece: a saúde, o trabalho, a casa e os bens que adquirimos.

A bandeira do Divino visita todas as casas que queiram recebê-la: do pobre, do rico, do branco, do negro, do bom católico e do mau católico. O Divino é o Missionário silencioso. É o Missionário de Jesus que recorda tudo o que Jesus disse. Por isso a visita da Bandeira é momento de reflexão para toda a família que a recebe. Momento de se perguntar sobre a vida em nossa comunidade: como vivemos nossa fé? Se estamos participando da Igreja e dos sacramentos? Se estamos vivendo como Jesus ensinou?

Devemos acompanhar a peregrinação da Folia, com respeito e em atitude de Oração, agradecendo a Deus a visita que faz à nossa Casa e as Bènçãos que Ele derramou sobre nós e nossa família.

Por fim, desejamos que você e sua familia que recebece a Bandeira continue perseverante na vida da sua comunidade e na fé da Igreja. Viva o Divino Espírito Santo!!!

Figura 16: Caderno de orações e hinos em louvor ao Divino Espírito Santo. 
As canções são executadas cada uma na sua hora: tem a canção de chegada, as canções durante a reza e a canção de despedida. Na Figura 17, a canção que anuncia aos moradores que a bandeira está chegando em sua casa. $\mathrm{Na}$

Figura 18, a orações inicial e a de encerramento, ambas realizadas dentro das moradias.

\section{7 - Salve o Divino \\ Salve o Divino Espírito Santo oiá, oiá, oiá. ( Bis) \\ O Divino Espírito Santo chegou aqui nesta morada \\ Veio guiando a bandeira na poeira da estrada, \\ Veio trazer sua benção, por nós muito esperada, \\ Veio tirar a esmola pra igreja da comunidade. \\ O Divino Espírito Santo, veio em forma de pombinha, \\ Quer entrar nesta morada, abençoar os seus filhinhos, \\ Proteger a sua esposa, seus irmão, tios e sobrinhos. \\ Agradecer a esmola pra seguir o seu caminho. \\ O Divino vai se embora muita gente está chorando, \\ Nessa triste despedida a bandeira estão beijando, \\ Bandeireiros se despedem, as violas estão tocando, \\ O Divino vai embora pra volta no outro ano.}

Figura 17: Hino que anuncia que a bandeira do Divino está chegando. Caderno de orações e hinos em louvor ao Divino Espírito Santo.

Em algumas casas, principalmente aquelas mais distantes dos vizinhos, os participantes tomam o lanche oferecido pelo anfitrião. É um momento de confraternização e de descontração também. Oferecem pães e bolos caseiros, biscoitos e café.

Todos rezam, a Folia canta conforme o que se apresenta no ambiente e, ao término, são oferecidos a todos os presentes pães e bolos, chocolate quente, café ou chá... A Folia canta novamente, fechando o ritual em frente ao Subimpério, agradecendo e abençoando a família e todos seguem de volta para o Império do Divino. (MARIANO, 2007, p. 110) 


\section{Oração Inicial}

(para todos os dias)

Animador - Queridos irmãos e irmãs, scjam todos bem vindos, é com grande alegria que vamos dar inicio a nossa caminhada:

Todos - Em nome do Pai, do Filho e do Espírito Santo. Amém.(pode ser cantado)

Animador - Que o amor do Pai, a Paz de Cristo Ressuscitado, e a Força do Espirito Santo esteja nessa casa.

Todos - Bendito seja Deus que nos reuniu no amor de Cristo.

Animador - Invoquemos a Luz do Espirito Santo para iluminar nossa caminhada.

Todos - Vinde, Espirito Santo, enchei os corações dos vossos fiéis e acendei neles o fogo do vosso amor. Enviai o vosso Espírito e tudo será criado e renovareis a face da terra.

Oremos: Ó Deus, que instruístes os corações dos vossos fiéis com a luz do Espírito Santo, fazei que apreciemos retamente todas as coisas segundo o mesmo Espírito e gozemos sempre da Sua consolaçāo. Por Cristo, Senhor nosso. Amém.

Animador - Com Fé unidos aos Anjos e Santos iniciemos nossa Caminhada cantando.

\section{Oração Final \\ (para todos os dias)}

Animador - Estamos terminando nossa caminhada, pela paz e pela unidade em nossa comunidade. $\mathrm{Na}$ alegria de Cristo ressuscitado e com a força do Espírito Santo, rezemos juntos e com fé ao Pai a oração que seu Filho nos ensinou:

Todos - Pai nosso que estais nos Céu...

Animador-Rezemos também a Maria, que esteve no cenáculo junto aos apóstolos, na descida do Espírito Santo:

Todos -Ave Maria...

Animador - Ó Divino Espírito Santo que, fortalecidos por esta devoção, sejamos mais firmes na fé e por isso nós sempre vos pedimos que derrame sobre nós os vossos dons. Por intercessão de Nossa Senhora de Pentecostes, desça sobre nós as bênçãos de Deus Todo-Poderoso que é: Todos -Pai, Filho e Espírito Santo. Amém.

Animador - Vamos em paz e que o Senhor sempre nos acompanhe.

Figura 18: Orações realizadas durante a visita da bandeira do Divino. Caderno de orações e hinos em louvor ao Divino Espírito Santo. 


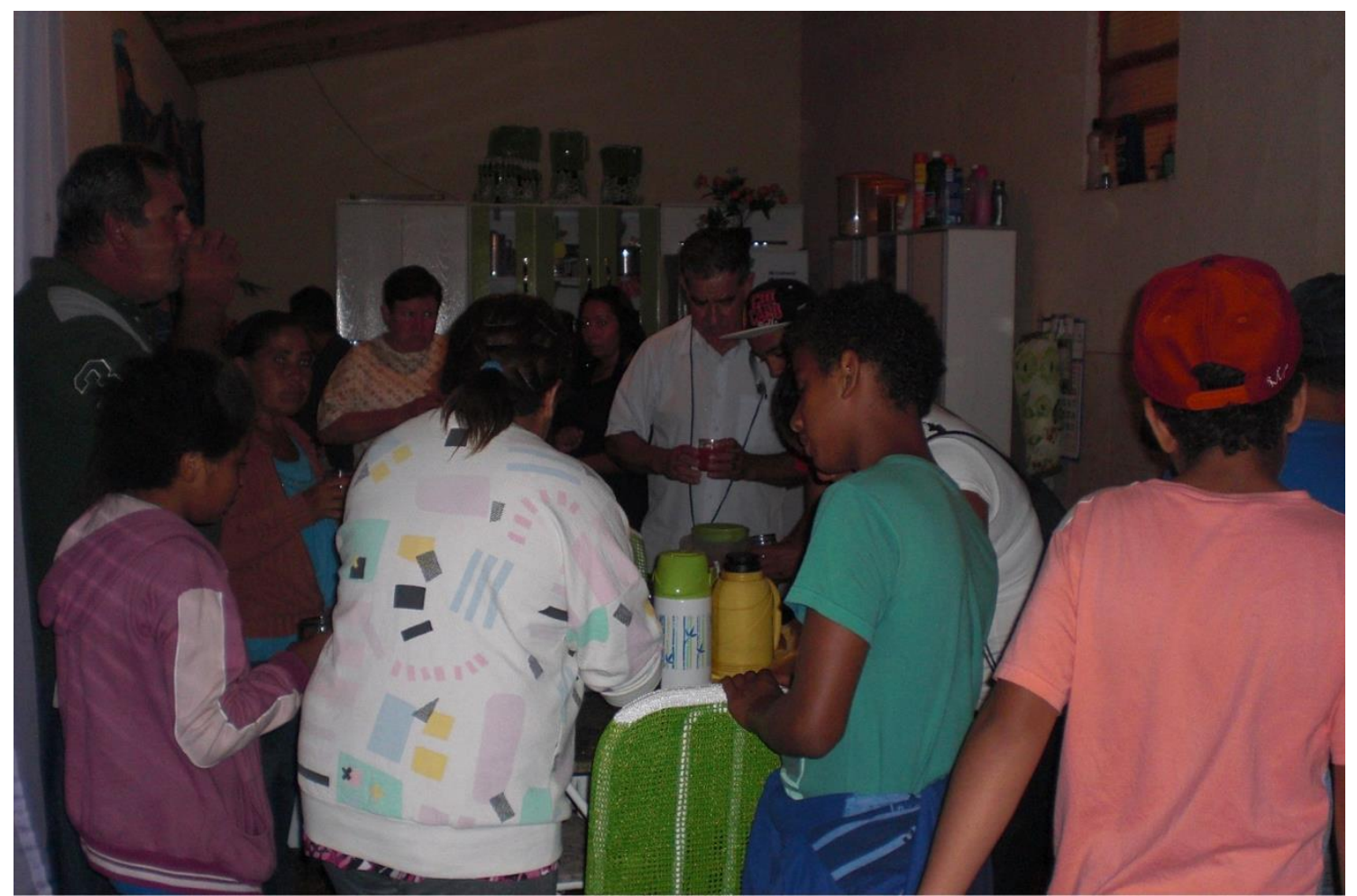

Foto 53: Lanche servido pelo morador aos participantes da bandeira do Divino. Foto: Lucinei Paes de Lima, abr. 2015.

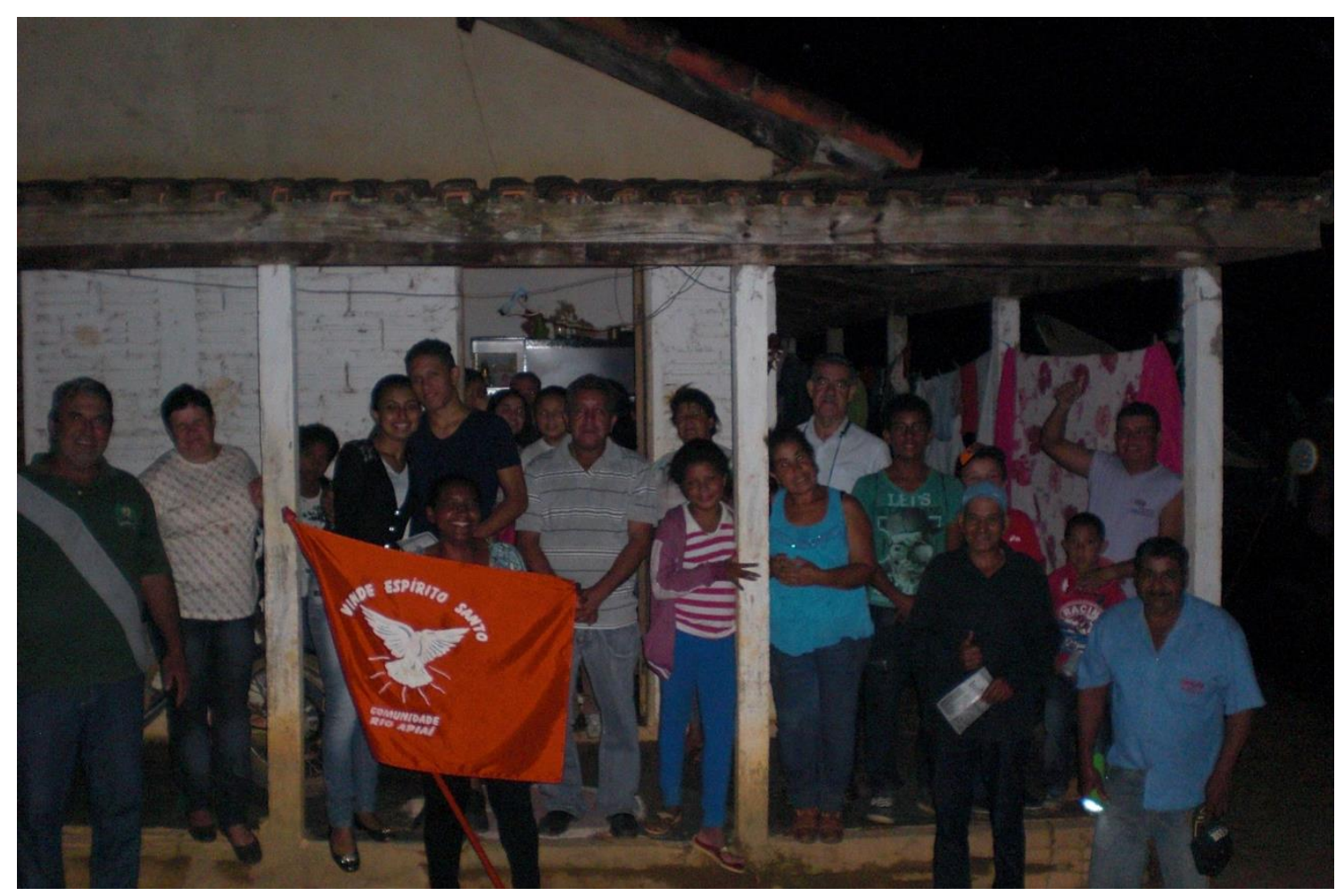

Foto 54: Última visita da noite na caminhada da bandeira do Divino. À frente, a moradora Cheila com a bandeira. Foto: Lucinei Paes de Lima, abr. 2015. 
Depois do lanche, os participantes avaliam o percurso para decidirem se é o momento de encerrar a caminhada da noite ou continuar um pouco mais. No dia em que acompanhamos a caminhada, a última casa visitada foi a da Sra. Cheila e as atividades se encerraram às $22 \mathrm{~h} 15$, um pouco mais tarde que o normal. Segundo nos informaram, costumam sair às $17 \mathrm{~h} 30 \mathrm{e}$ encerrar por volta das 21 horas, dependendo da distância e da quantidade de casas no trecho que vão percorrer. Nesta noite, ao todo participaram cerca de trinta pessoas e algumas nos disseram que é como uma promessa começar e ir até o fim em todas as caminhadas.

\subsection{A Festa do Divino Espírito Santo de Ribeirão Branco}

A festa do Divino Espírito Santo aparece como mediação para o encontro, que não é um simples encontro: é trabalho conjunto, é solidariedade, é a reunião para a realização de algo. (MARIANO, 2007, p. 23)

Para conhecermos a história das festas do Divino Espírito Santo de Ribeirão Branco, realizamos, por indicação de alguns camponeses, uma entrevista com o Sr. José Luiz, ministro extraordinário da Eucaristia e catequista, que há 40 anos coordena a festa na igreja matriz. Ele nos contou que os bairros rurais, depois de finalizarem as peregrinações e recolherem as doações, iniciam a preparação do grande dia - da festa do Divino Espírito Santo na igreja matriz.

Ele explicou que na peregrinação das bandeiras do Divino, como já é de costume, os bairros rurais pedem a doação da prenda e de dinheiro. A igreja, para preparar a festa, fica somente com o resultado da coleta do dinheiro. As prendas ficam com as comunidades para realizarem as suas próprias festas, principalmente as do seu padroeiro. Desse modo, mantémse viva essa tradição das festas, como afirma o Sr. José Luiz:

Todas as 24 comunidades rurais realizam a festa do seu padroeiro e é sempre em outro período para não coincidir com a festa do Divino, que todo mundo tem que vir pra cidade. Além disso, a igreja matriz procura sempre estar presente nos bairros rurais, realizando as missas que acontecem pelo menos uma vez por mês em cada uma das comunidades, algumas até duas vezes no mês. Já os sacramentos funcionam assim: os casamentos da zona rural são todos feitos na igreja matriz e os batizados são na própria comunidade. As crismas também são realizadas aqui na matriz, uma vez no ano, e a primeira comunhão é feita nas comunidades, também uma vez no ano. (Entrevista com José Luiz, 6 jan. 2016)

Segundo o Sr. José Luiz, como são 24 comunidades rurais, fica difícil para o pároco conseguir realizar mais de uma missa por mês em cada bairro, mas são esses encontros que aproximam a igreja matriz dos bairros rurais e reforçam o calendário das atividades, entre 
festas, reuniões de catequistas, coral de canto e animação, e dirigentes das comunidades. Ele também nos contou como era o dia da festa do Divino Espírito Santo na cidade:

Nesse dia a cidade fica movimentada e a festa tem que ser feita no ginásio de esportes municipal para acomodar todos os participantes. O ponto de encontro das bandeiras dos bairros e a procissão até o local da missa é um grande momento, em que cada bairro traz os seus cantadores e a sua bandeira, que é enfeitada com muito capricho com fitas coloridas pelos moradores daquele bairro. A festa é finalizada com bingos e leilão das prendas doadas por aqueles que receberam o Divino em suas casas. (Idem)

O Sr. José Luiz nos falou sobre a história das festas do Divino no município e nos forneceu imagens de seu arquivo pessoal que retratam desde a primeira festa em Ribeirão Branco.

A primeira festa do Divino de Ribeirão Branco foi no dia 3 de junho de 1979. Essa tradição foi trazida pelo Sr. José da Silva Júnior, mais conhecido como Seu Bil. Ele era de Paraty, no estado do Rio de Janeiro, e como lá eles realizavam a festa, ele veio morar em Ribeirão Branco e então ele organizou a primeira festa, sendo inclusive o primeiro festeiro do Divino em Ribeirão Branco. (Idem)

Sobre as primeiras festas realizadas em Ribeirão Branco, o Sr. José Luiz ainda nos disse

que:

Tinha bingo, leilão... O dinheiro para fazer a festa era arrecadado através da coleta de dinheiro feita durante a andança dos devotos quando levavam a bandeira para as casas de quem queria recebê-la.

Vai visitar as famílias, reza a novena do livrinho, canta os hinos e cada família oferece o dinheiro, a esmola para o santo. Naquela época, tinha leilão e, no final, todo dinheiro arrecadado era somado e pagava as despesas, o que sobrava ficava com a igreja. A preparação era toda feita nas casas dos festeiros. Eles se reuniam para recolher e preparar as prendas arrecadadas. Aí tinha o que chamavam do dia da "matança", que era o dia de matar e temperar os animais doados para então assar na fornalha.

O povo vinha, aquele monte de gente ajudar e, depois de matar, levavam tudo no rio para lavar - o gostoso era isso! Colocar tudo em cima de um caminhão, as galinhadas, leitoas, e iam todo mundo pro rio. Era bem do povão mesmo! E daí quem assava... a primeira pessoa que assava era a D. Nega, já falecida. Então colocava tudo na fornalha e depois era levado para o local da festa, em torno da igreja, e daí era feito o leilão onde as pessoas "arrematavam", davam o lance, e o maior arrematava e ficava com a prenda. Nossa! De repente, até começavam a brigar, tinha uma hora, um querendo ganhar do outro, e com isso gerava dinheiro pra festa.

Pra vender na festa, tinha a barraquinha do pastel e do bolinho, que é típico da nossa região, o encapotado. Ah, esse era o que mais saía e até hoje é o que mais vende nas festas.

O que mudou daqueles tempos pra cá é que hoje em dia não tem mais o famoso leilão, porque se fazia muito leilão e geralmente as pessoas levavam as prendas e não pagavam na hora, levava fiado e mandavam marcar para pagarem depois, só que depois não pagava nunca mais e fica ruim a igreja ficar cobrando. Agora tem o bingo, inclusive agora tem bingo de moto, e na 
última festa teve até um carro zero quilômetro. Mas a maneira de arrecadar as prendas ainda é do jeito antigo, se anota no caderninho durante a visita da bandeira e depois passa pegando. Então a outra coisa que mudou foi isso, é que essas prendas arrecadadas ficam pra comunidade fazer a sua festa do padroeiro. Então elas não vêm mais para a matriz fazer a festa, o que vem das comunidades é o dinheiro arrecadado e com ele se organiza a festa. Na última festa, pedimos para as comunidades rurais uma leitoa de cada uma e isso ficou como contribuição pra festa do Divino. (Idem)

Ao compararmos o relato do Sr. José Luiz com o que vimos durante a peregrinação da bandeira do Divino no bairro do Rio Apiaí, notamos que não houve muitas mudanças e que as pessoas mantêm a tradição da realização da festa em moldes bastante parecidos. Mariano fala sobre a participação dos devotos nos festejos do Divino:

A Festa do Divino, neste período era um momento de encontro, em que o devoto contribuía para a sua realização e participava dos festejos, de forma espontânea, mantendo o caráter de religiosidade popular. Uma dessas expressões populares está na atuação da Folia do Divino, que peregrinava pelos bairros rurais em nome do Espírito Santo e recolhia prendas (porcos, vacas, galinhas, e outros produtos da roça), garantindo a bênção do Espírito Santo sobre a família que os recebia, como sobre a colheita. (MARIANO, 2007, p. 176)

Como podemos notar, o envolvimento das pessoas para a realização da peregrinação e da festa se dá através de uma forma coletiva de trabalho, e todos contribuem como podem. A esse respeito, Paulino (2012, p. 376) esclarece que: "além do trabalho na construção propriamente dito, todos doam, preparam e depois compram a comida durante a festa, o que configura uma tripla contribuição".

O nosso entrevistado, Sr. José Luiz, nos disse que tinha vinte anos quando preparou o coral para cantar na primeira festa do Divino Espírito Santo de Ribeirão Branco (Foto 56). Na Foto 57, temos a imagem do primeiro Encontro das Bandeiras de Ribeirão Branco em junho de 1979. Por fim, o Sr. José Luiz junto ao ex-padre do município, Cícero Vieira, na Foto 58. 


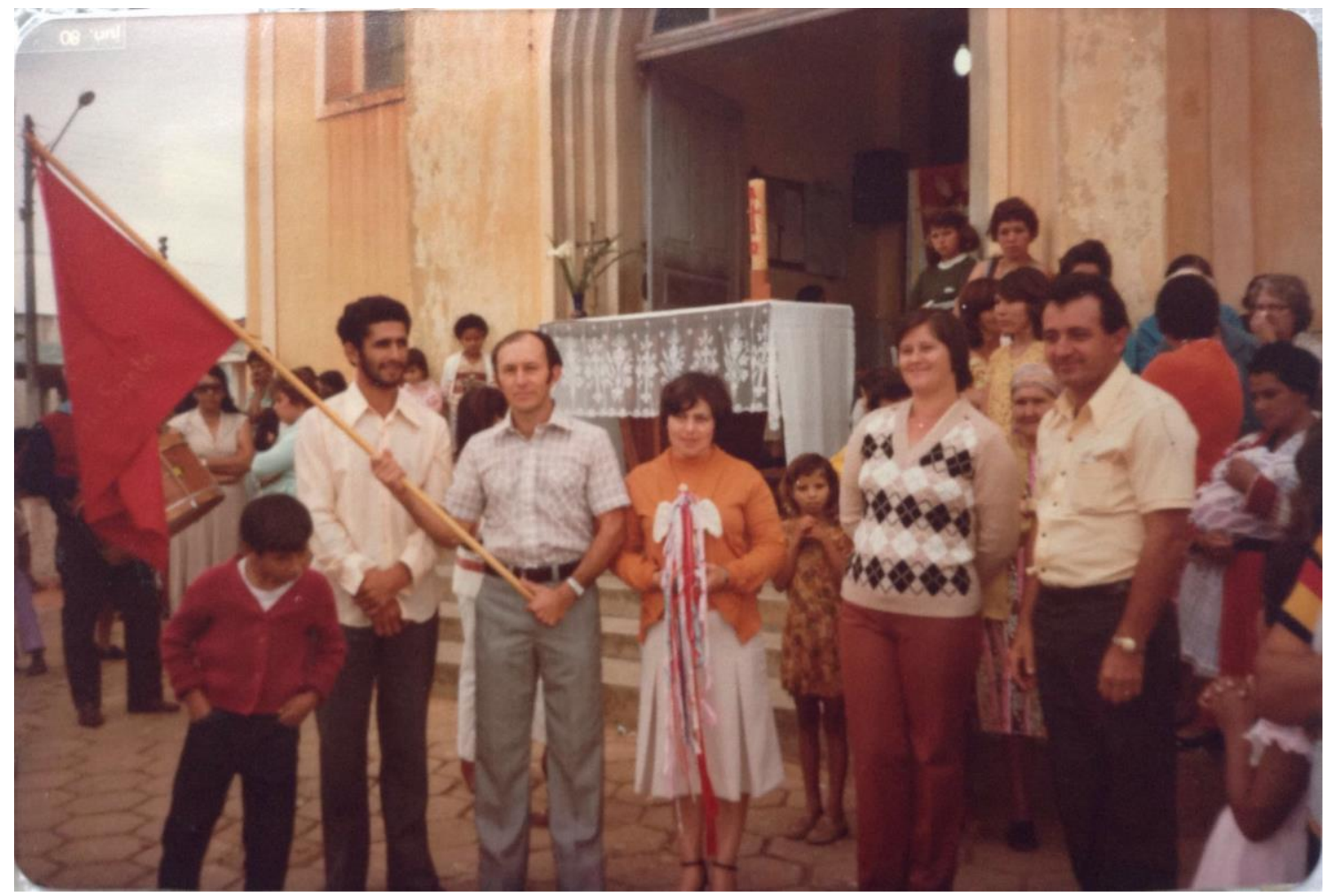

Foto 55: Primeiro casal de festeiros do Divino de Ribeirão Branco, Sr. Bil e sua esposa. Foto: Arquivo pessoal do Sr. José Luiz, 1979.

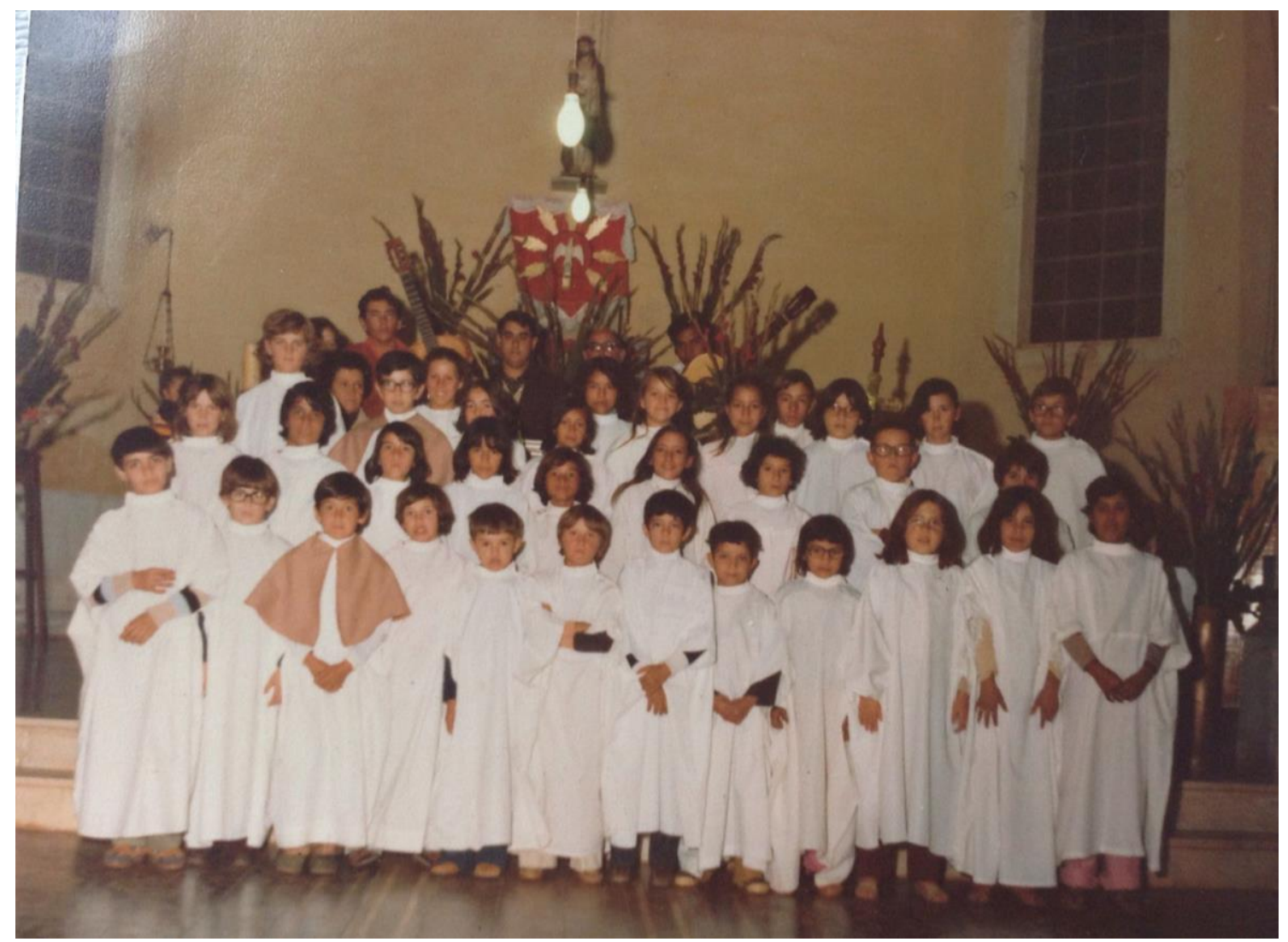

Foto 56: Primeiro coral de canto para a Festa do Divino de Ribeirão Branco. O entrevistado, Sr. José Luiz, é o segundo depois do violeiro, ao fundo, da esquerda para direita, com blusa marrom. Foto: Arquivo pessoal do Sr. José Luiz, 1979. 


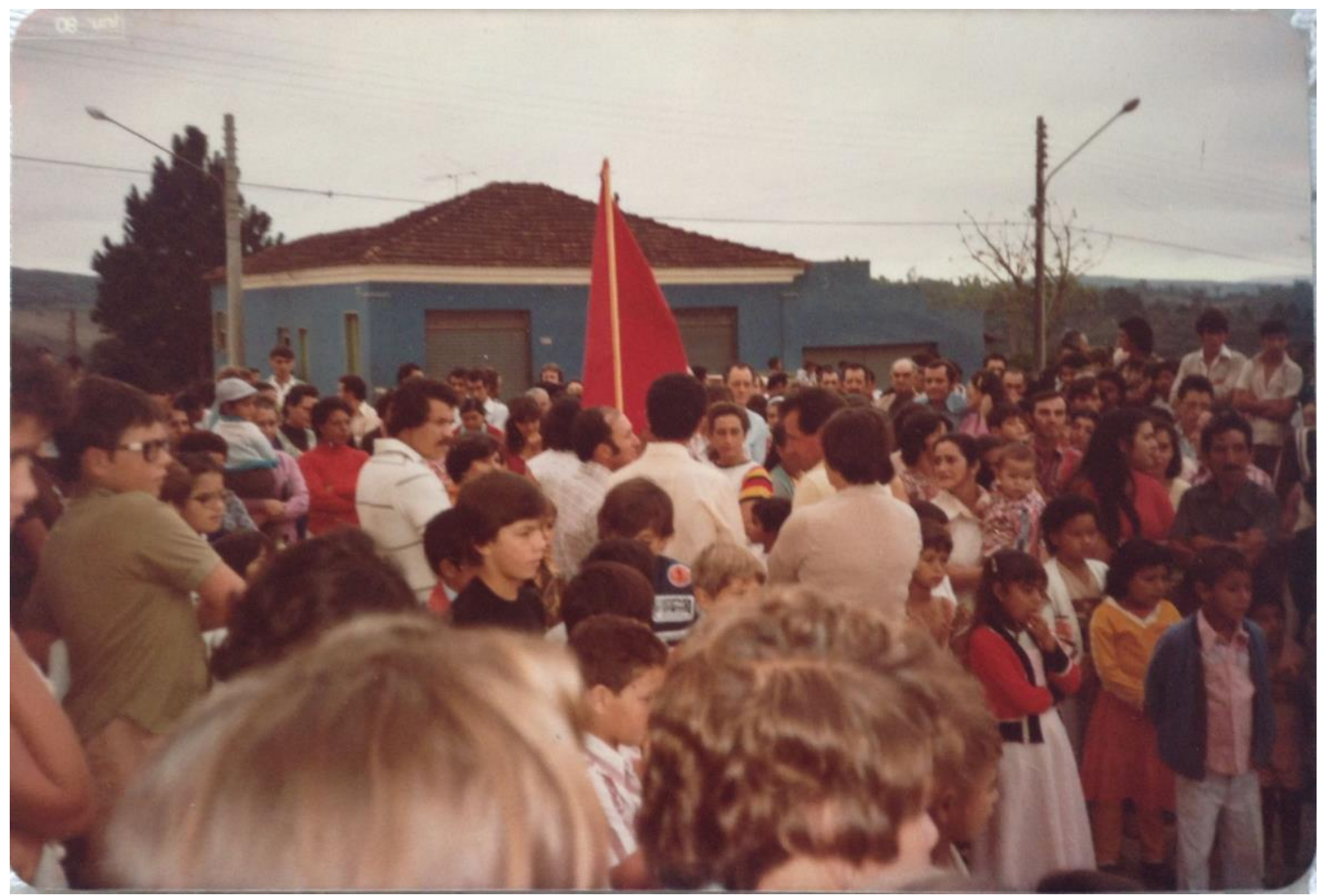

Foto 57: Primeira festa do Divino de Ribeirão Branco, jun. 1979. Foto: Arquivo pessoal de José Luiz.

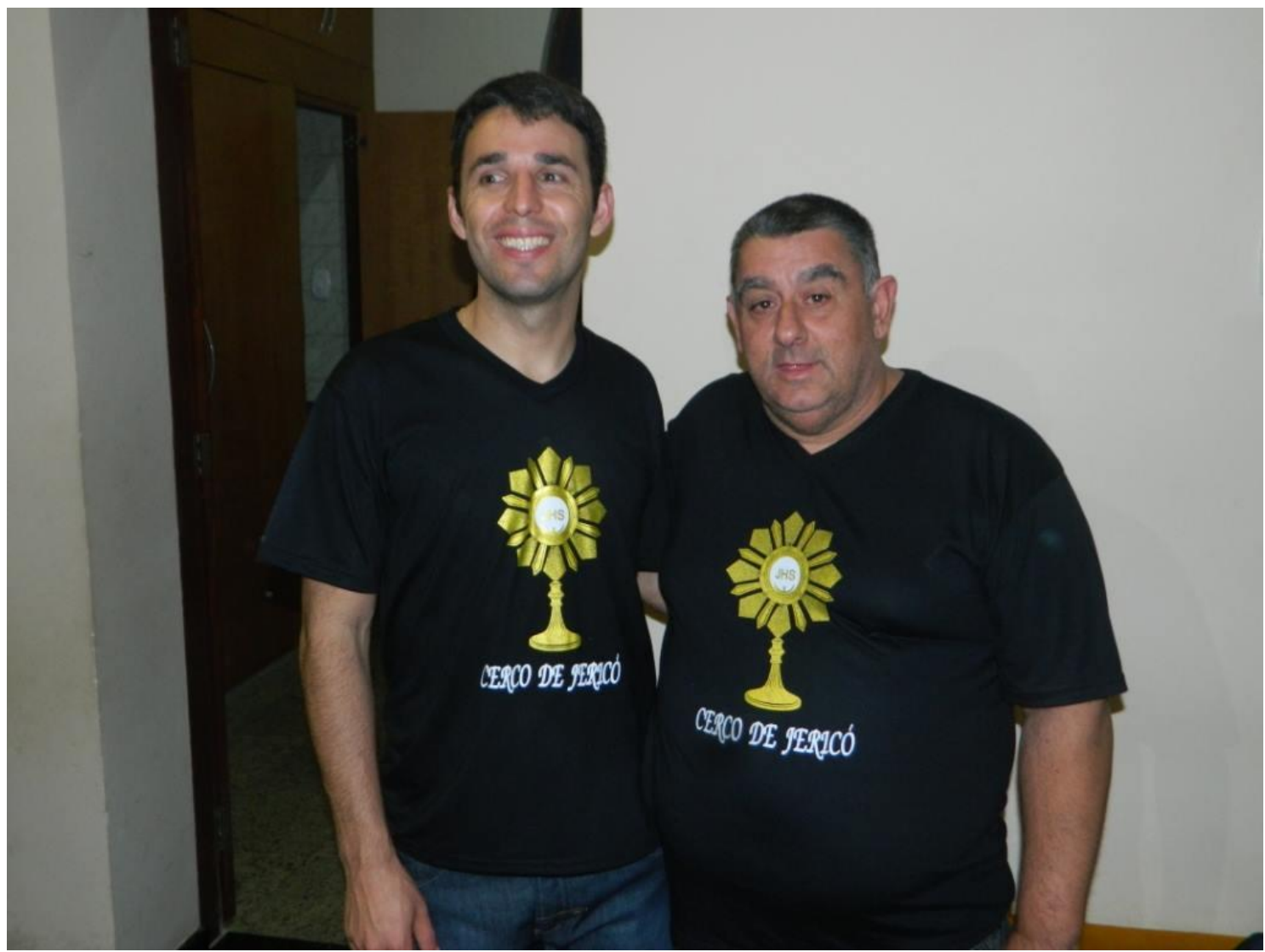

Foto 58: José Luiz (direita) e o pároco do município, Pe. Cícero Vieira. Foto: Arquivo pessoal de José Luiz. 


\section{SIMBOLOS DO DIVINO ESPÍRITO SANTO}

BANDEIRA: É a bandeira de Deus e de Seu povo.

Através dela a fé e a religiosidade são levadas por toda a cidade. A bandeira é vermelha para simbolizar o sangue dos mártires- de nossa igreja, desde os tempos de Jesus Cristo até os dias atuais.

Onde a bandeira passa são derramadas bênçãos para as familias. Beijar a bandeira-é uma forma de devoção e respeito ao sagrado.

POMBA: Sinal do amor de Deus, símbolo de esperança, paz, mansidão Os-exemplos estão em: Mateus, 3,16 - Batismo de Jesus. Gênesis 1,21-O Espírito de Deus paira sobre as águas. Gênesis 8,8-12-A arca de Noé.

FOGO: Este símbolo é bíblico, está em capítulo 2 de Atos dos Apóstolos, quando os apóstólos e Maria se reuniram no Cenáculo é sobre eles vieram a línguas de fogo, estabelecendo assim o dia de Pentecostes. Um outro exemplo estál no está no Antigo Testamento, em 1 Reis, capítulo 18, versículos 36-38, onde Elias pede a Deus o fogo do Céu.

ÁGUA: A água simboliza a pureza, a vida. O Espirito Santo é a "água viva" descida do céu para nos lavare purificar.

O Espirito Santo é a terceira Pessoa da Santíssima Trindade, mistério insondável e maravilhoso de Deus-Pai, que criou o universo única e exclusivamente por amor, Deus-Filho que despojou-se da glória de ser Deus, para nos salvar do pecado e da morte eterna e Deus-Espírito Santo, o Consolador e Santificador, que Deus concede após purificar nosso coração

Figura 19: Símbolos do Divino Espírito Santo. Caderno de orações e hinos da bandeira do Divino. 
José Luiz também nos falou dos símbolos e seus significados para a igreja, e que isso é repetido de pai para filhos para que a tradição permaneça, dessa maneira, nas comunidades. Esses símbolos e sinais são partes da cultura popular, como observado por Mariano:

As necessidades e satisfações, as realizações e conquistas humanas são atribuídas às relações estabelecidas com um plano "superior", em que uma comunicação é estabelecida a partir da interpretação de símbolos e sinais. Neste sentido, há uma interpenetração do profano no mundo do sagrado e vice-versa; as reverências pagãs à natureza voltam-se agora, a um Deus, aos santos etc., mas continuavam pagãs, passando a ser entendidas como folclóricas. E o folclore, por sua vez, é aqui considerado parte constitutiva da cultura popular, pois nasce no seio do povo. (MARIANO, 2007, p. 34)

Na Figura 19, apresentamos os símbolos do Divino Espírito Santo e seus significados.

A festa do Divino de Ribeirão Branco segue a mesma metodologia desde a primeira realizada em 3 de junho de 1979. No dia da festa, a cidade fica cheia de gente, a grande maioria daqueles que receberam o Divino em suas casas estará junto aos seus vizinhos para representar a sua comunidade e agradecer ao Divino as graças alcançadas.

\subsection{A Festa do Divino de Ribeirão Branco em 2015}

Tivemos a oportunidade de participar da festa do Divino de Ribeirão Branco e acompanhamos todo o percurso da festa - desde a concentração dos cavaleiros e das comunidades em frente à rodoviária até a procissão que se encerrou na chegada a Igreja matriz. Os cavaleiros iniciaram a procissão com as bandeiras, seguidos pelos andores dos santos e por todos os fiéis presentes.

O Sr. José Luiz nos disse que, no dia da festa, a primeira atividade é a concentração das bandeiras. Esperam todos os bairros rurais chegarem e, geralmente às 13 horas, é iniciada a procissão que segue até a igreja para realização da missa. Depois da missa, tem outra procissão, de despedida: é quando a imagem do Divino percorre toda a cidade em caminhada com os devotos até o encerramento, com bingo e venda de comes e bebes.

$\mathrm{Na}$ Foto 59, temos a saída dos cavaleiros e o início da procissão dos devotos em caminhada até a catedral. 


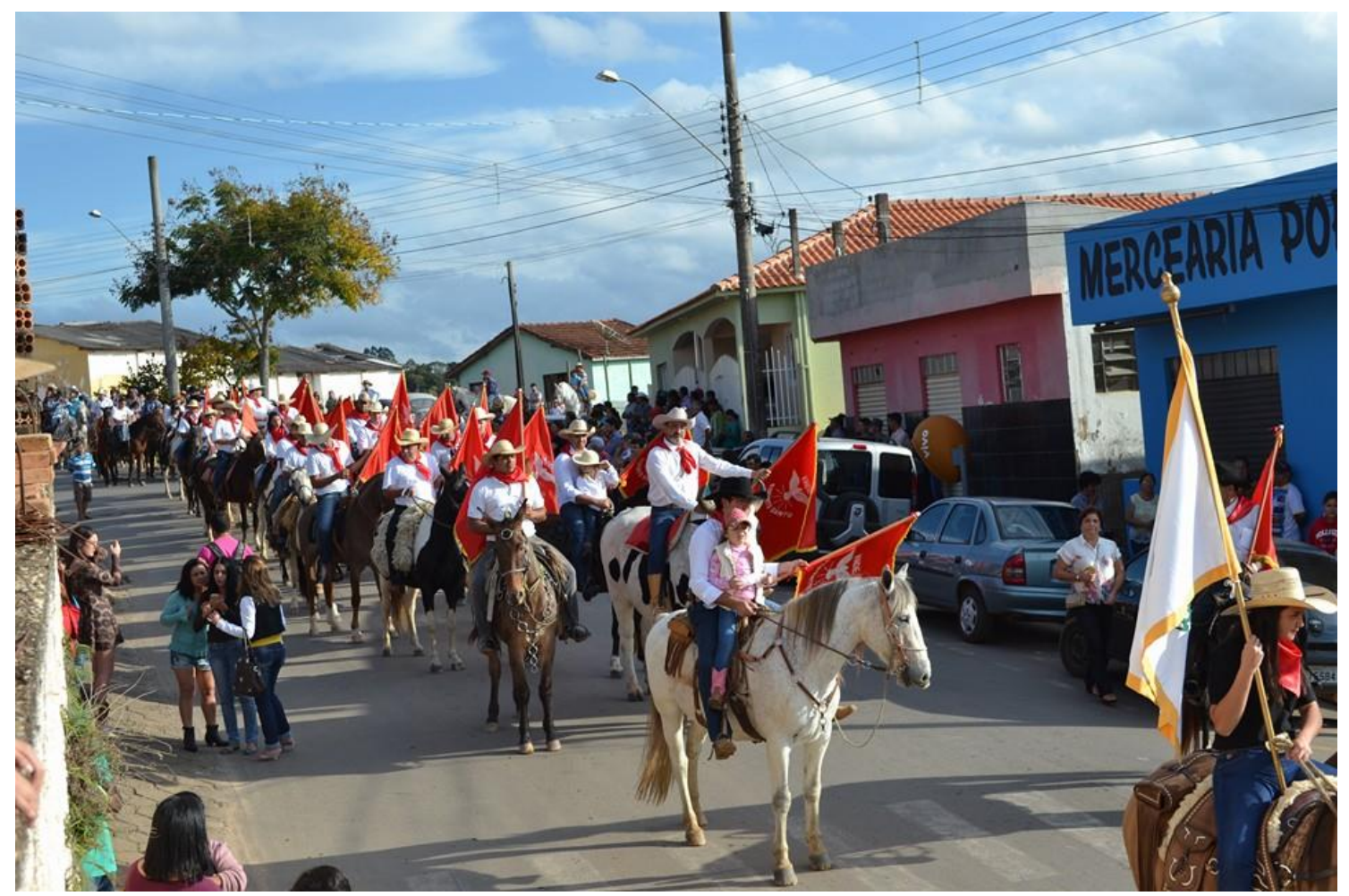

Foto 59: Cavaleiros abrem e os fiéis acompanham a procissão do Divino em Ribeirão Branco. Foto: Lucinei Paes de Lima, maio 2015.

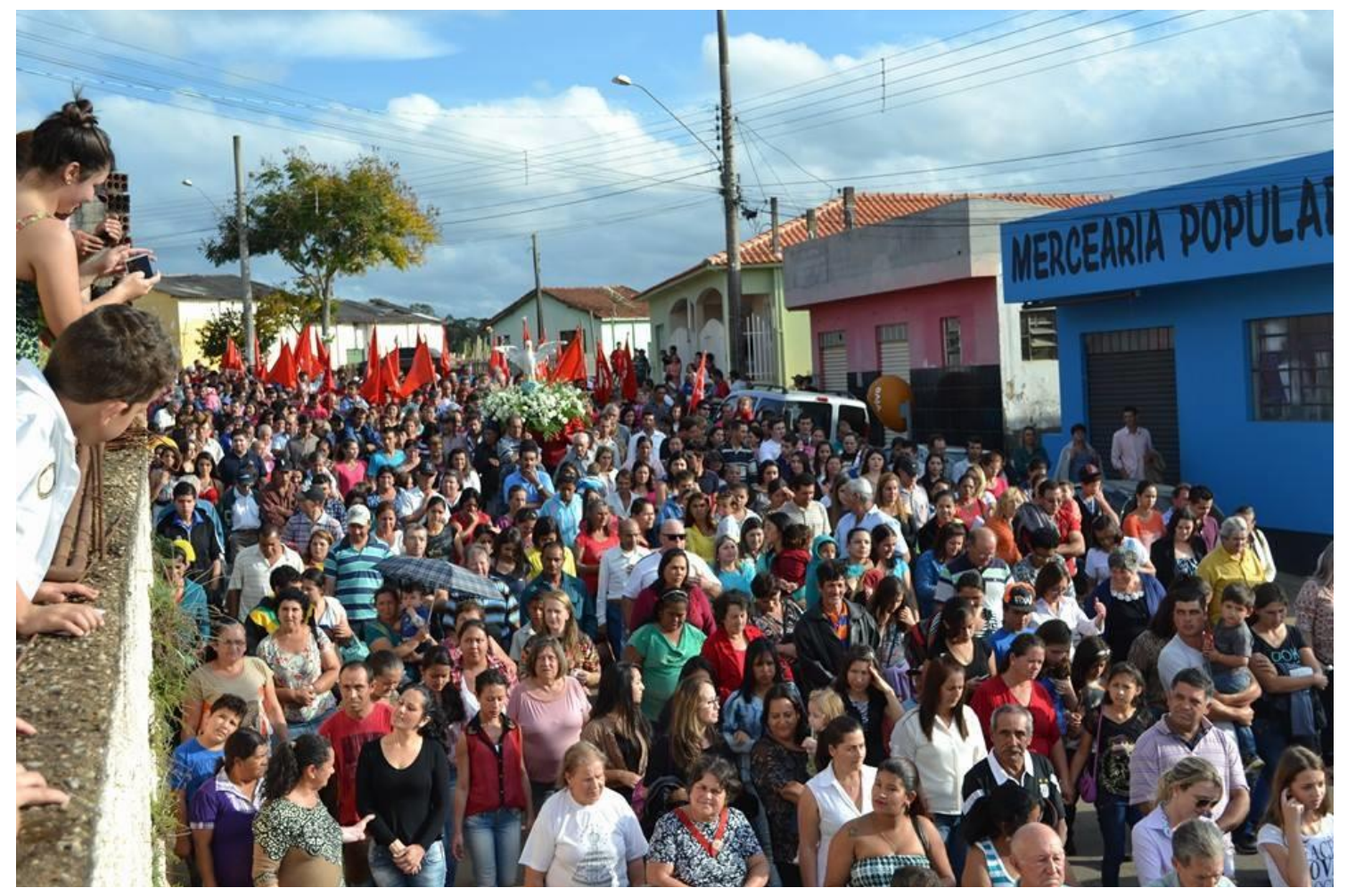

Foto 60: Caminhada da procissão do Divino até a igreja matriz. Foto: Marco Cravo, maio 2015. 
Como dissemos anteriormente, a festa do Divino Espírito Santo é cheia de símbolos e sinais. Não por acaso, o Sr. José Luiz nos contou um fato curioso sobre o ritual de preparação da procissão:

Aqui nas festas, nós temos o costume de arrumar os andores com as imagens dos santos. São arrumados os andores, todos muito enfeitados, e isso é muito forte aqui. Uma coisa que eu queria que você colocasse [escrevesse] aí, é que nas nossas procissões, há muitos anos, o santo que abre a procissão é o Santo Benedito. É ele que sempre vai na frente. Porque, diziam os mais antigos, que o São Benedito era um santo vingativo... coitado... mas conta-se que teve uma festa há muito tempo e que o São Benedito sempre saía na frente nas procissões, e nessa festa, contam que puseram o São Benedito pra trás e puseram o nosso padroeiro da cidade [Senhor Bom Jesus] na frente e ele pra trás. Quando chegou no meio da procissão, formou uma tempestade muito feia... e isso você pode perguntar pra qualquer pessoa mais antiga pra você ver! Todos se lembram disso! E daí, na hora do apuro, eles lembraram que o São Benedito estava atrás e então correram, passaram o santo pra frente e realmente a tempestade se desfez. Só deu uma garoa bem de leve e a procissão terminou bem. Depois disso, nunca mais deixaram de pôr o São Benedito na frente! É uma tradição que todo mundo preserva e vigia para nunca ocorrer de novo!

Então, na hora de arrumarmos o andor com os santos, o primeiro que se pega pra arrumar bem bonito é o São Benedito, claro, só depois pegamos outro. Porque a gente não quer correr o risco. A gente não sabe se tem a ver, mas melhor não abusar, né? Não custa nada fazer do mesmo jeito! Então, quando vem um outro padre, eles não entendem muito, mas também deixam a gente fazer como de costume. Então aqui o povo vem mesmo cobrar de você que está organizando pra ver se está tudo certo, se o São Benedito foi o primeiro a ser arrumado com as flores. (Entrevista com José Luiz, 6 jan. 2016)

Na Foto 61, temos o início da procissão com a imagem de São Benedito guiando a multidão em caminhada até a igreja matriz.

Durante toda a procissão, os participantes rezam e cantam. O coral de canto é um espetáculo à parte. Na Foto 62, podemos ver parte dos músicos que vêm das comunidades e se juntam para animar a festa. Tem sanfona, pandeiro, bumbo e todos os violeiros se vestem de vermelho, representando a cor da bandeira do Divino Espírito Santo. 


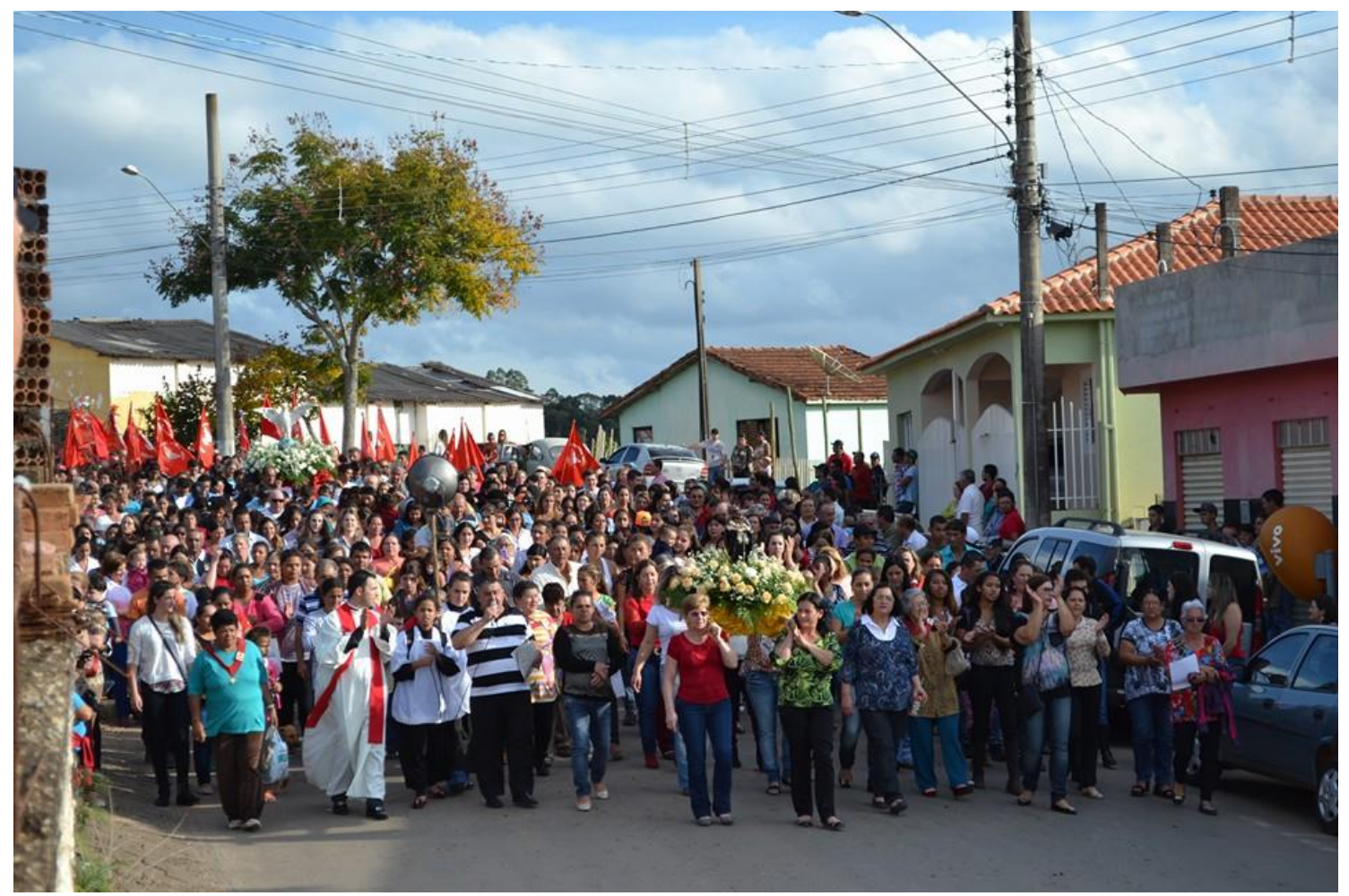

Foto 61: Início da procissão com o andor de São Benedito sempre à frente. Foto: Marco Cravo, maio 2015.

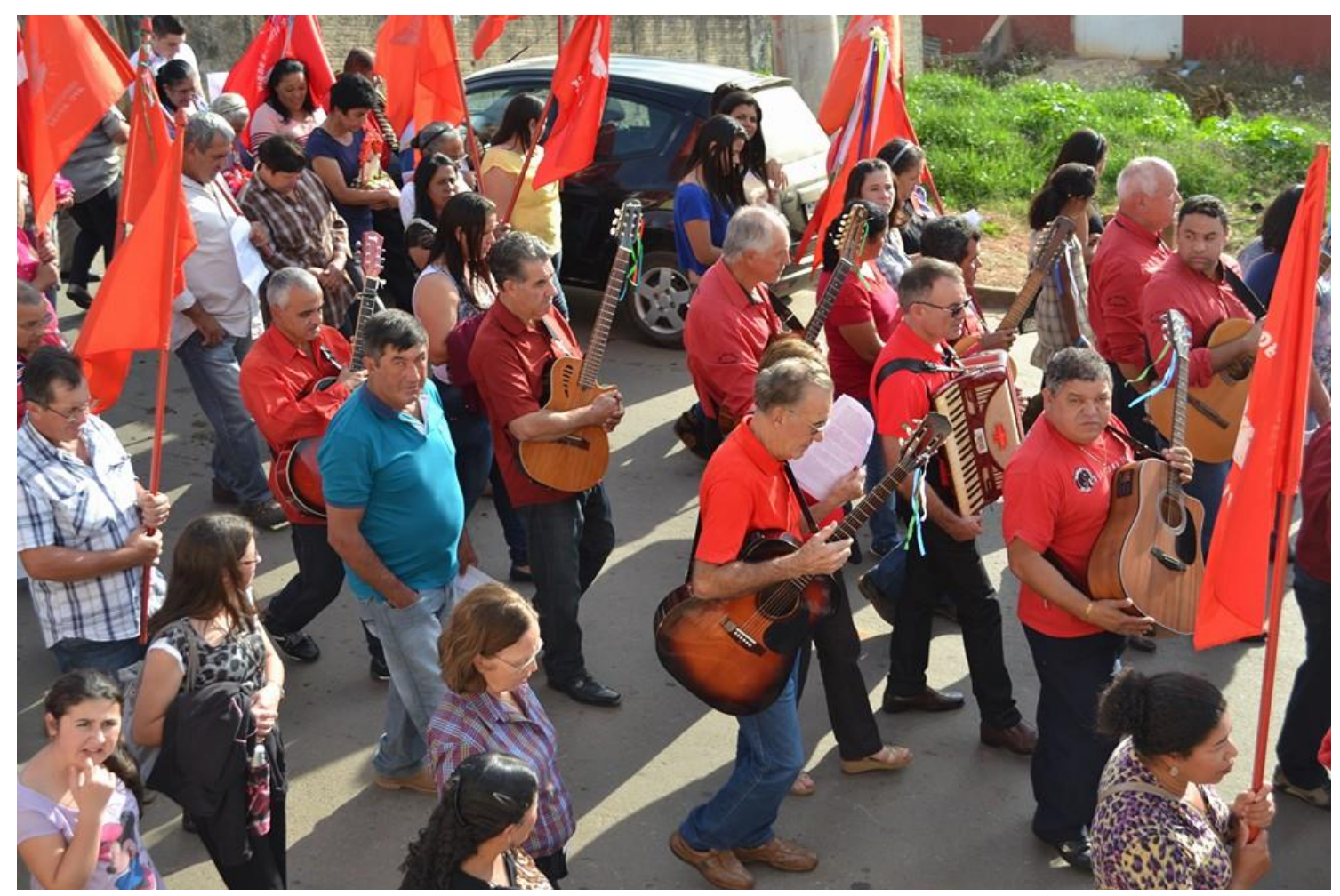

Foto 62: Músicos com seus instrumentos durante a procissão na Festa do Divino. Foto: Marco Cravo, maio 2015. 


\subsection{Calendário das festas religiosas}

Como já mencionado pelo Sr. José Luiz, além das festas de cada comunidade rural em que celebram o dia do seu padroeiro, todos se juntam na cidade para a realização de três festas durante o ano. A primeira é a do Divino, que tem como referência o dia de Pentecostes. A segunda é a do padroeiro do município, Senhor Bom Jesus, que é comemorada no dia 6 de agosto. A última festa é a de Nossa Senhora da Conceição, comemorada no dia 8 de dezembro. Todas as festas seguem a mesma metodologia da festa do Divino e têm uma programação de peregrinação e missas que antecede o dia dos santos. Nas imagens abaixo, podemos ver os cartazes de divulgação dessas festas no ano de 2015 e os prêmios que foram sorteados no jogo do bingo. ${ }^{24}$

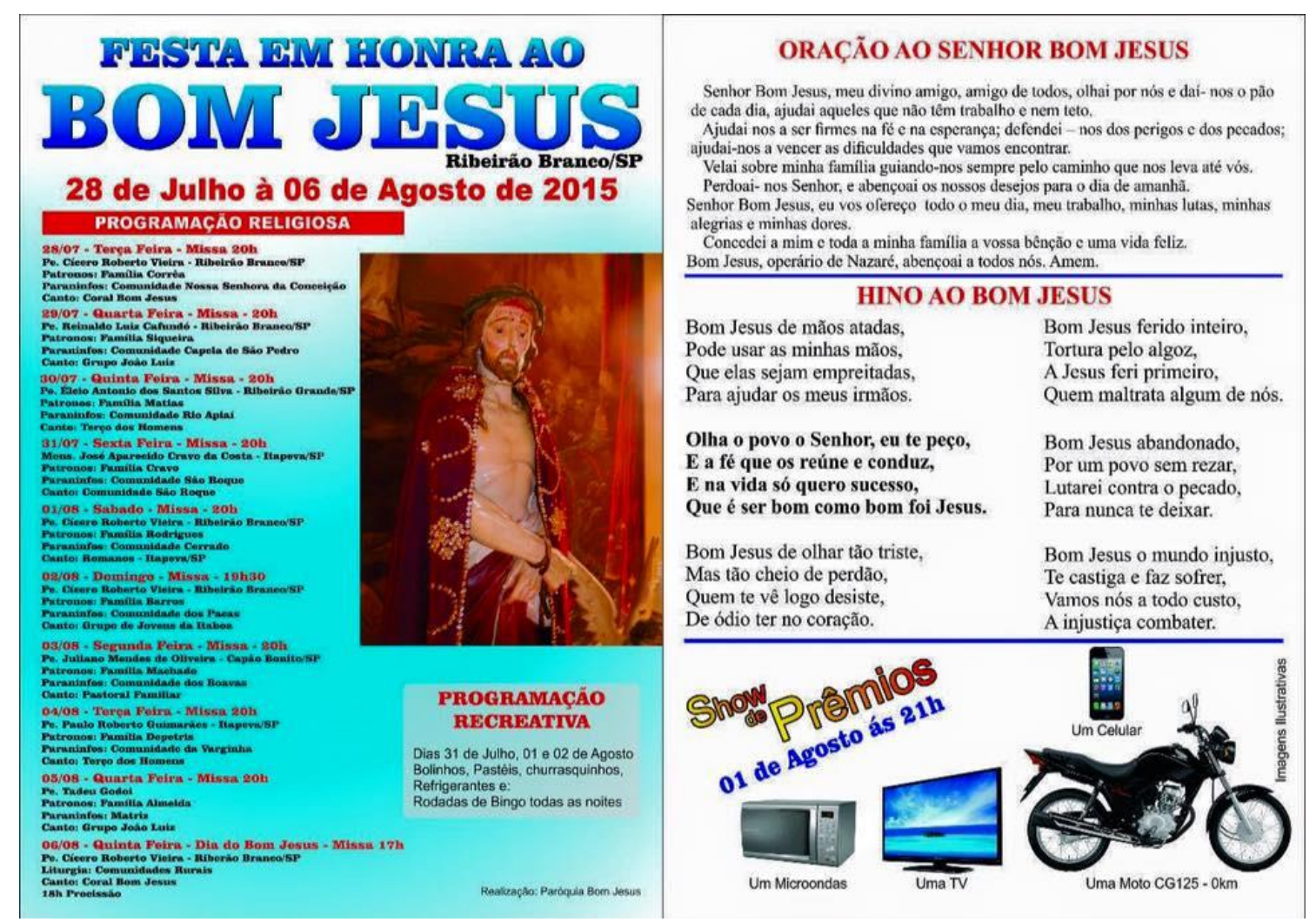

Figura 20: Cartaz da festa do padroeiro de Ribeirão Branco. Foto: Arquivo digital da Paróquia Senhor Bom Jesus.

\footnotetext{
${ }^{24}$ Cada comunidade recebe uma quantidade de cartelas de bingo para vender. Em 2015, cada cartela era vendida por 10 reais. Com uma só cartela as pessoas concorrem a todos os prêmios anunciados para aquela festa.
} 


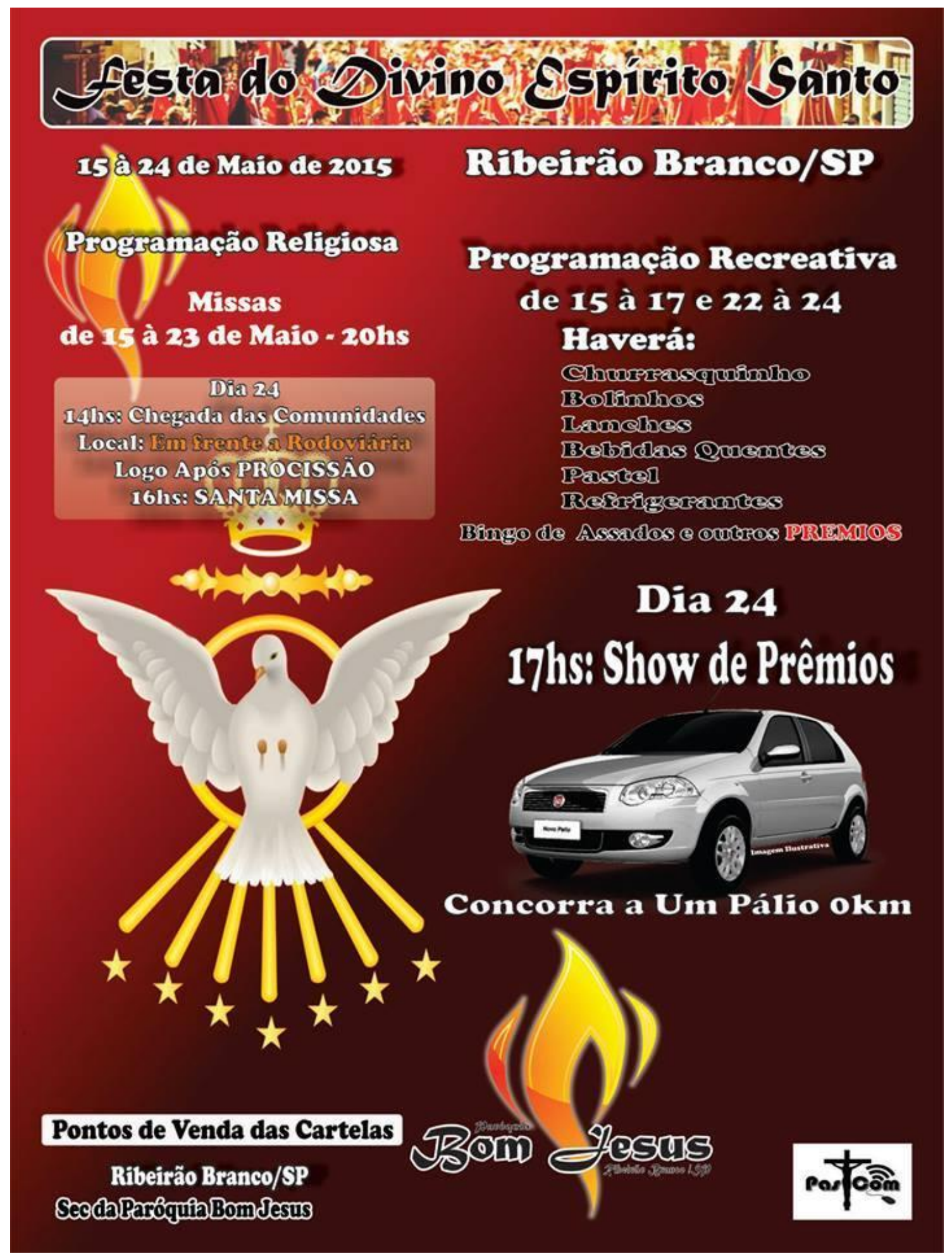

Figura 21: Cartaz da Festa do Divino Espírito Santo. Foto: Arquivo digital da Paróquia Senhor Bom Jesus. 


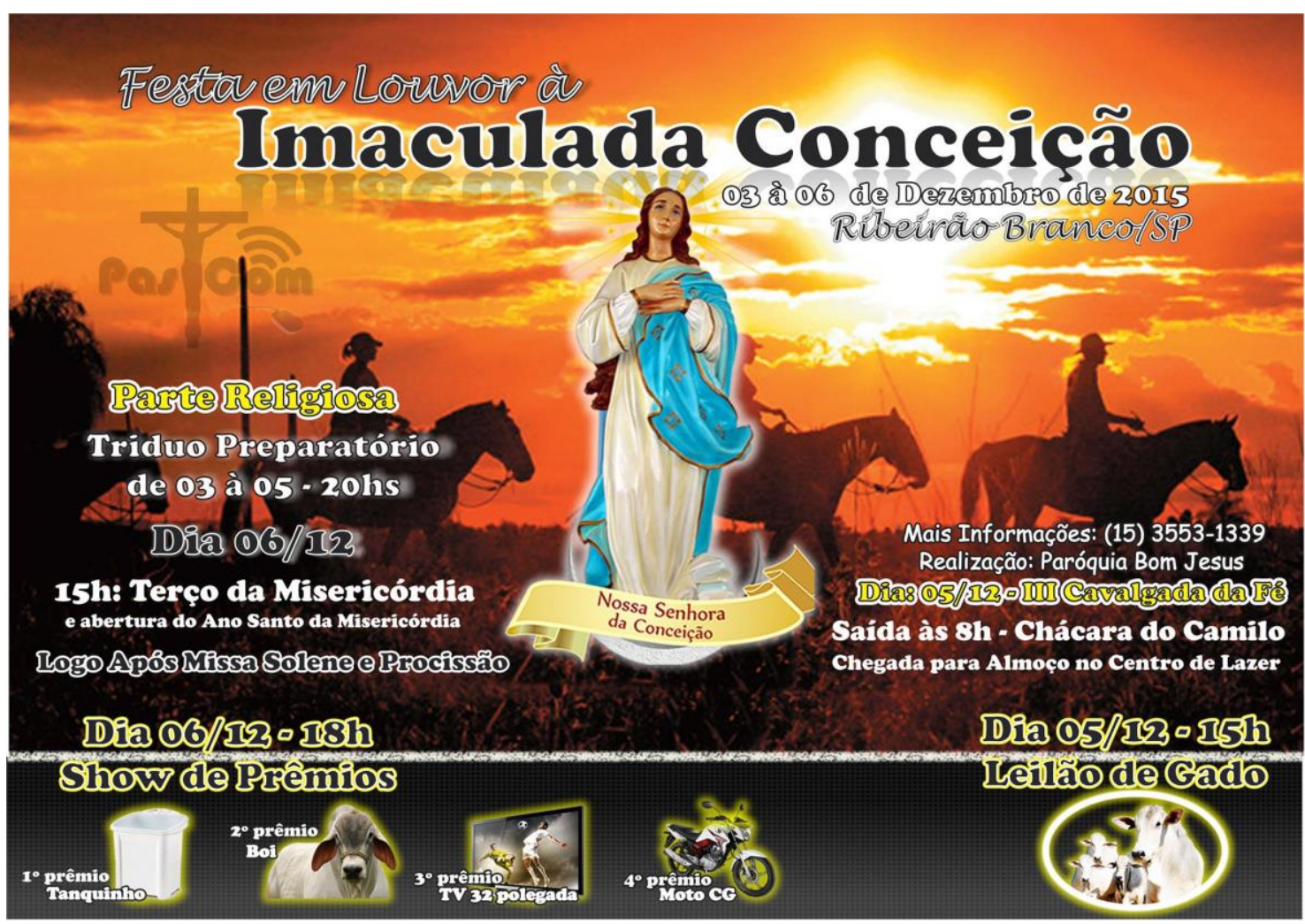

Figura 22: Cartaz da Festa de Nossa Senhora da Conceição. Foto: Arquivo digital da Paróquia Senhor Bom Jesus.

Tivemos a oportunidade de acompanhar um dia de peregrinação da caminhada do Bom Jesus na comunidade do Rio Apiaí. Enquanto na festa do Divino as comunidades (cada uma com a sua bandeira) se encarregam de percorrer as moradias de seu bairro rural, para a festa do Bom Jesus existe apenas uma imagem que percorre todas as 24 comunidades rurais. Funciona da seguinte maneira: a igreja matriz organiza um cronograma em que uma comunidade rural recebe a imagem e ela, após a permanência da imagem na capela do bairro por até dois dias, se encarrega de levar a imagem do santo até a comunidade vizinha mais próxima, e assim sucessivamente. Então, em vez de a imagem percorrer as moradias dos camponeses, ela fica na capela e são os camponeses que vão visitá-la.

Um detalhe importante é que a comunidade que está levando a imagem é responsável por realizar a celebração no bairro vizinho, tanto as orações quanto os hinos que animam o encontro. Na primeira comunidade, geralmente é o pároco que realiza a missa inaugurando as visitas da imagem do Senhor Bom Jesus. Neste dia, a comunidade anfitriã participa da celebração como expectadora e, no final, oferece um lanche para os visitantes e todos os presentes.

A comunidade que recebeu a imagem do santo acerta a data e o horário para leva-la para a próxima comunidade, e essa rotina se repete até que todas as demais comunidades tenham 
recebido a visita da imagem do santo. Nos contaram que, para os doentes e acamados que têm dificuldades para ir à capela, a comunidade se responsabiliza por levar a imagem até eles, garantindo que todos tenham contato com o santo.

Nas imagens abaixo, a comunidade do bairro São Roque entrega a imagem do Senhor Bom Jesus à comunidade do bairro do Rio Apiaí. Esse encontro entre duas comunidades vizinhas é um momento de confraternização entre os camponeses, tanto que eles, depois de finalizada a reza, se entregam a demoradas conversas do lado de fora da capela. Parece não ter importância o horário já avançado, mesmo que no dia seguinte tenham um longo dia de trabalho pela frente.

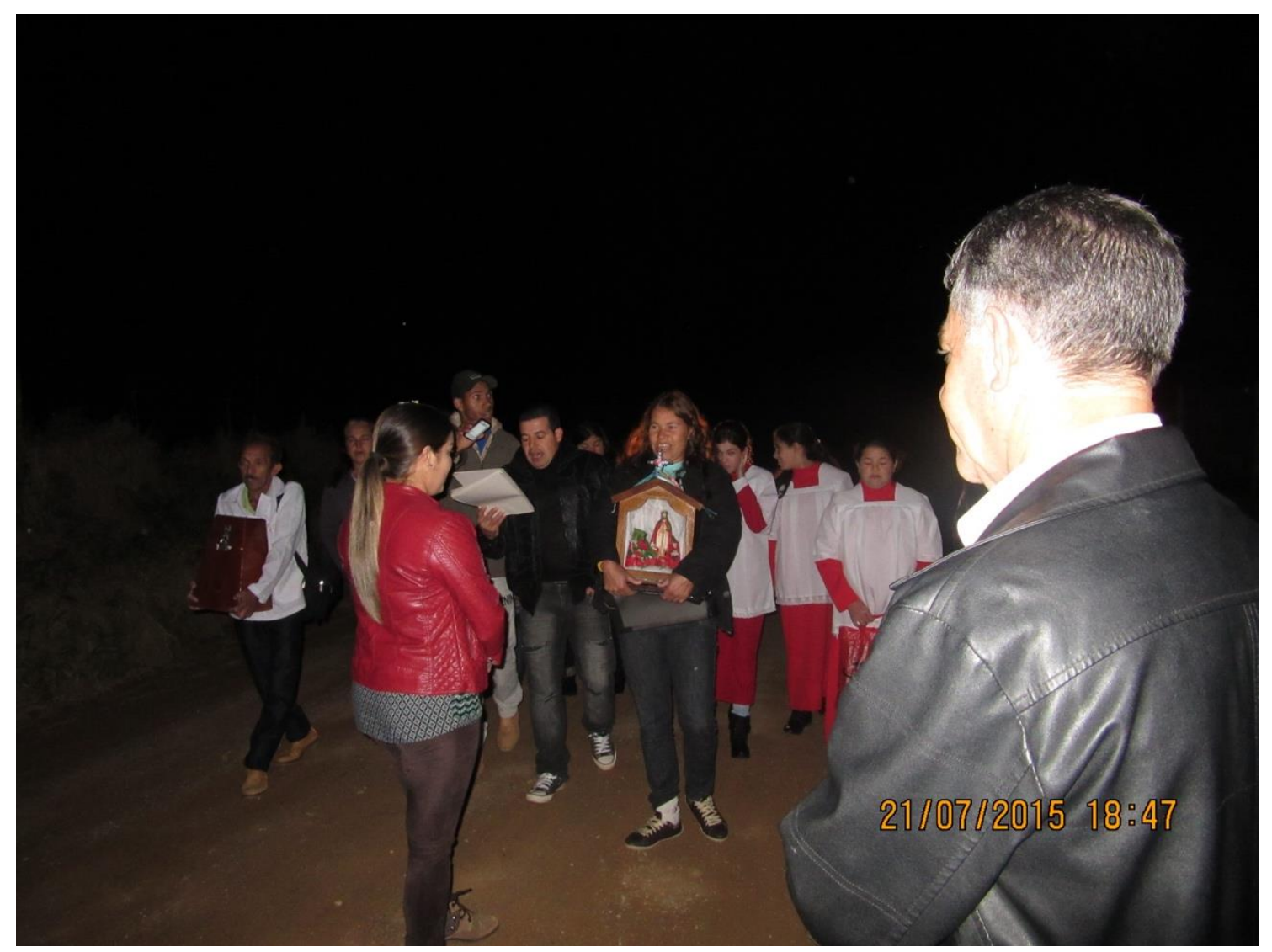

Foto 63: Chegada da imagem do Senhor Bom Jesus à capela do bairro do Rio Apiaí. A imagem foi trazida pela comunidade do bairro São Roque.

Foto: Lucinei Paes de Lima, jul. 2015. 


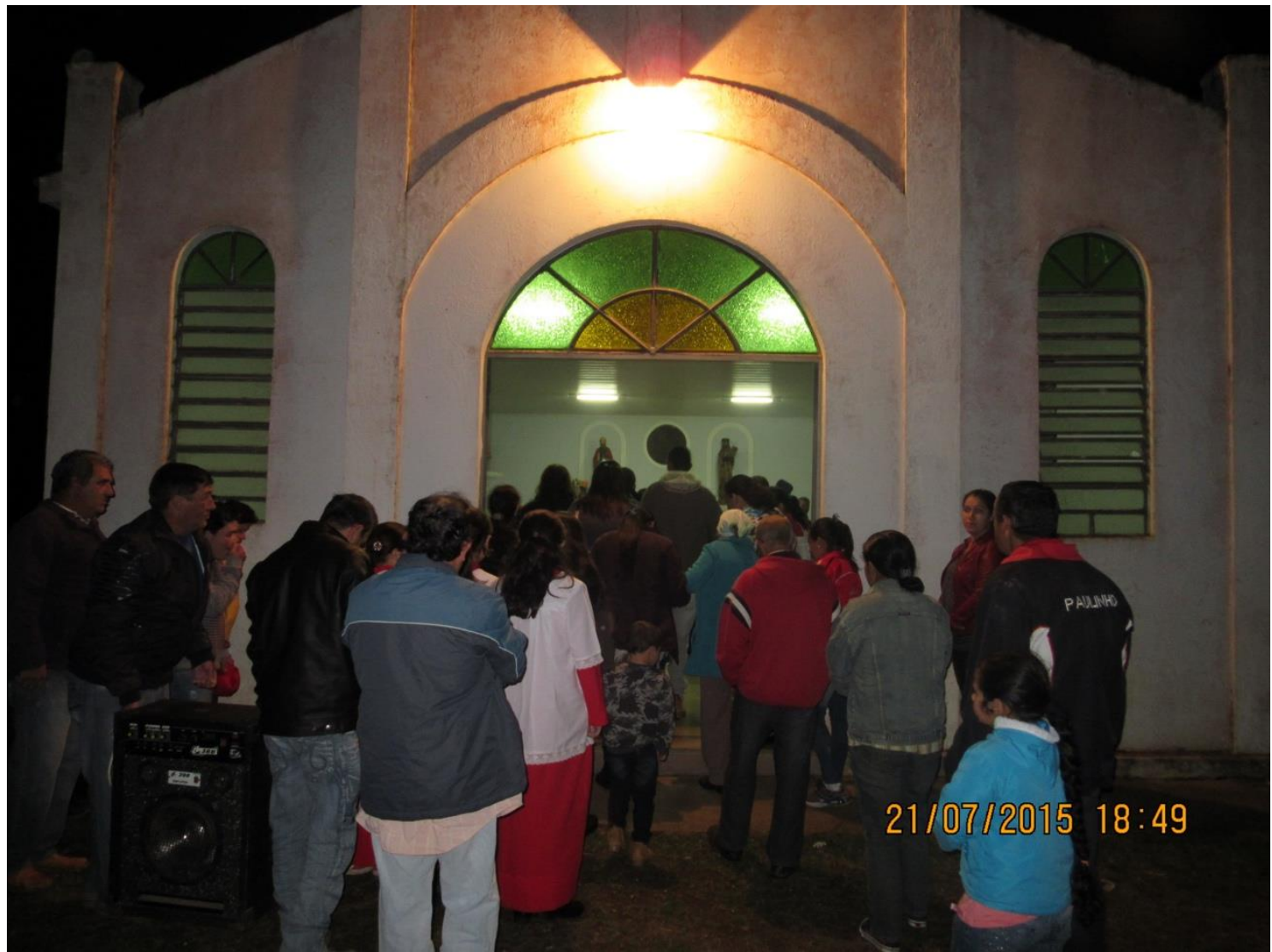

Foto 64: Visita do Senhor Bom Jesus, procissão até a capela do bairro do Rio Apiaí. Foto: Lucinei Paes de Lima, jul. 2015.

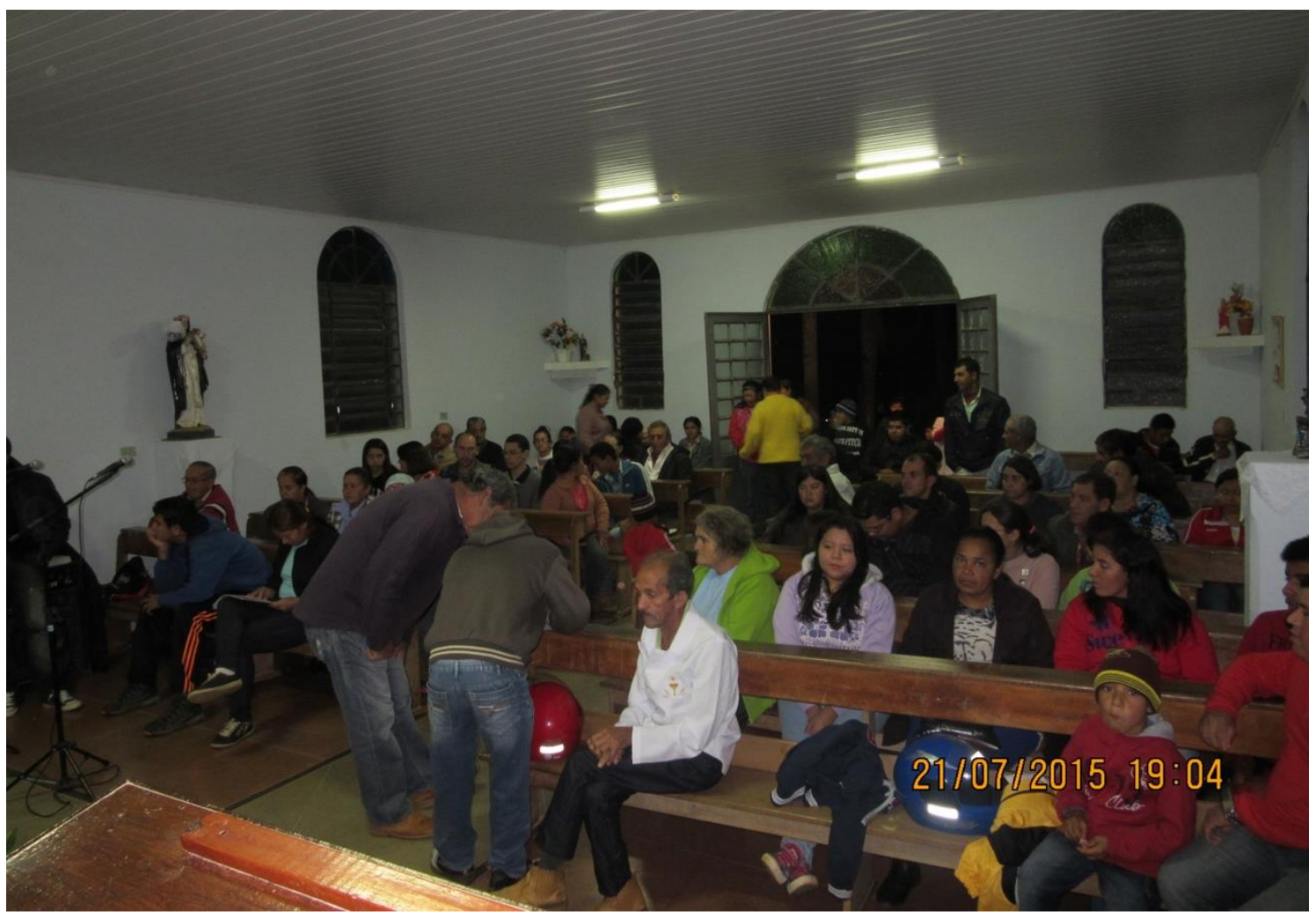

Foto 65: Visita do Senhor Bom Jesus no bairro do Rio Apiaí. Camponeses se acomodam para o início da celebração. Foto: Lucinei Paes de Lima, jul. 2015. 
Na Foto 66, temos um registro da Cavalgada da Fé de 2015, em comemoração à festa de Nossa Senhora da Conceição. Os cavaleiros trazem a imagem da santa até a igreja matriz e, ao chegarem, recebem a água benta lançada pelo padre do município. Vale dizer que a imagem de Nossa Senhora da Conceição não circula pelos bairros rurais, como acontece nas outras festas.

Por fim, os bairros rurais encerram o calendário religioso com a novena de Natal. Também pudemos acompanhar o último dia de novena na comunidade do bairro do Rio Apiaí. Essa novena acontece nas capelas de todos os bairros, é feita somente com os habitantes do mesmo bairro e não há uma imagem que circula - geralmente montam um presépio que permanece até o último dia da novena.

Depois da reza as crianças da catequese fizeram uma apresentação de teatro e, em seguida, houve uma confraternização com bolo e refrigerante para todos os presentes. Os primeiros a receberem o bolo são as crianças.

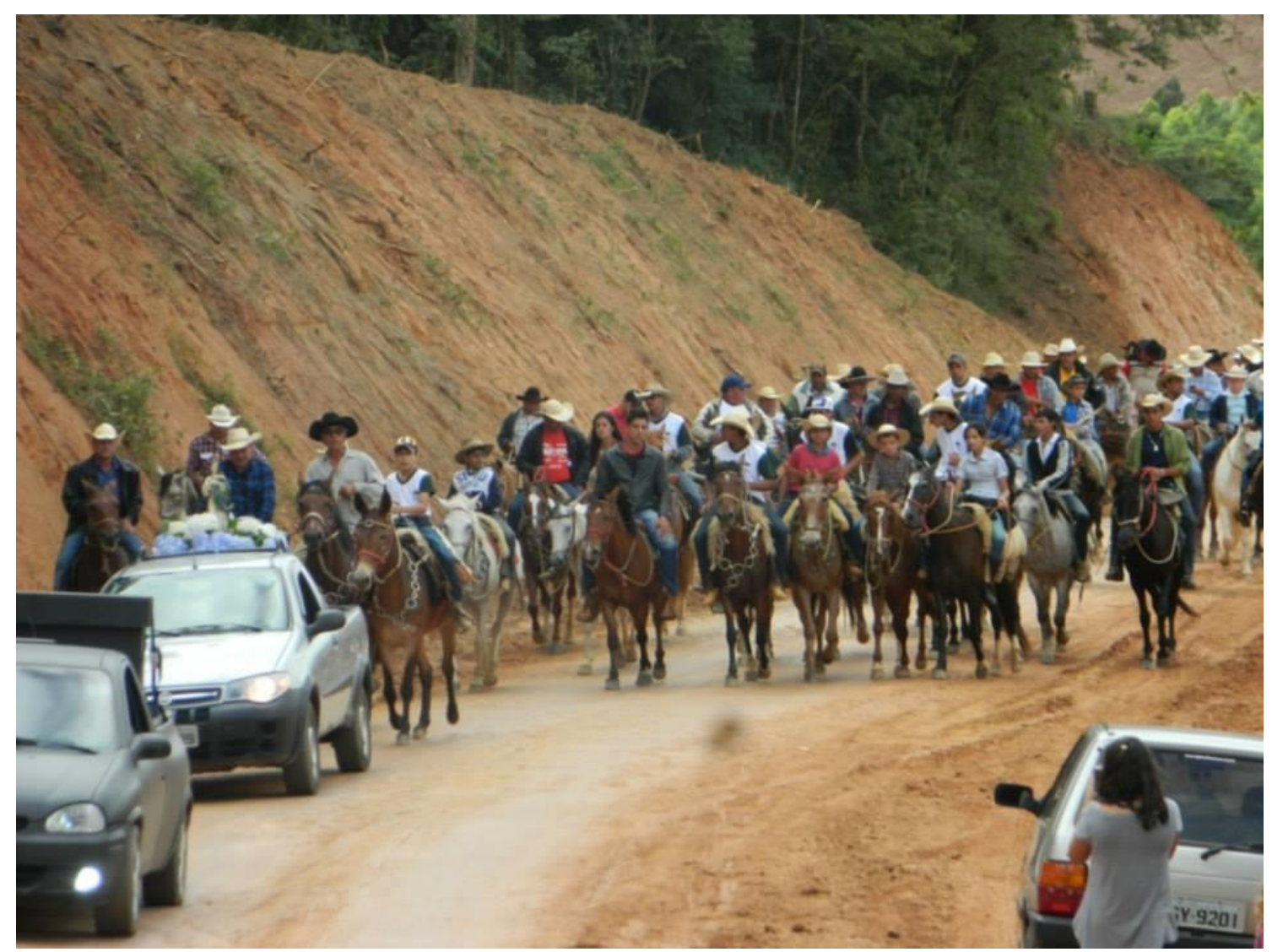

Foto 66: Cavalgada da fé na Festa de Nossa Senhora da Conceição, dez. 2015. Foto: Arquivo digital da Paróquia Senhor Bom Jesus. 


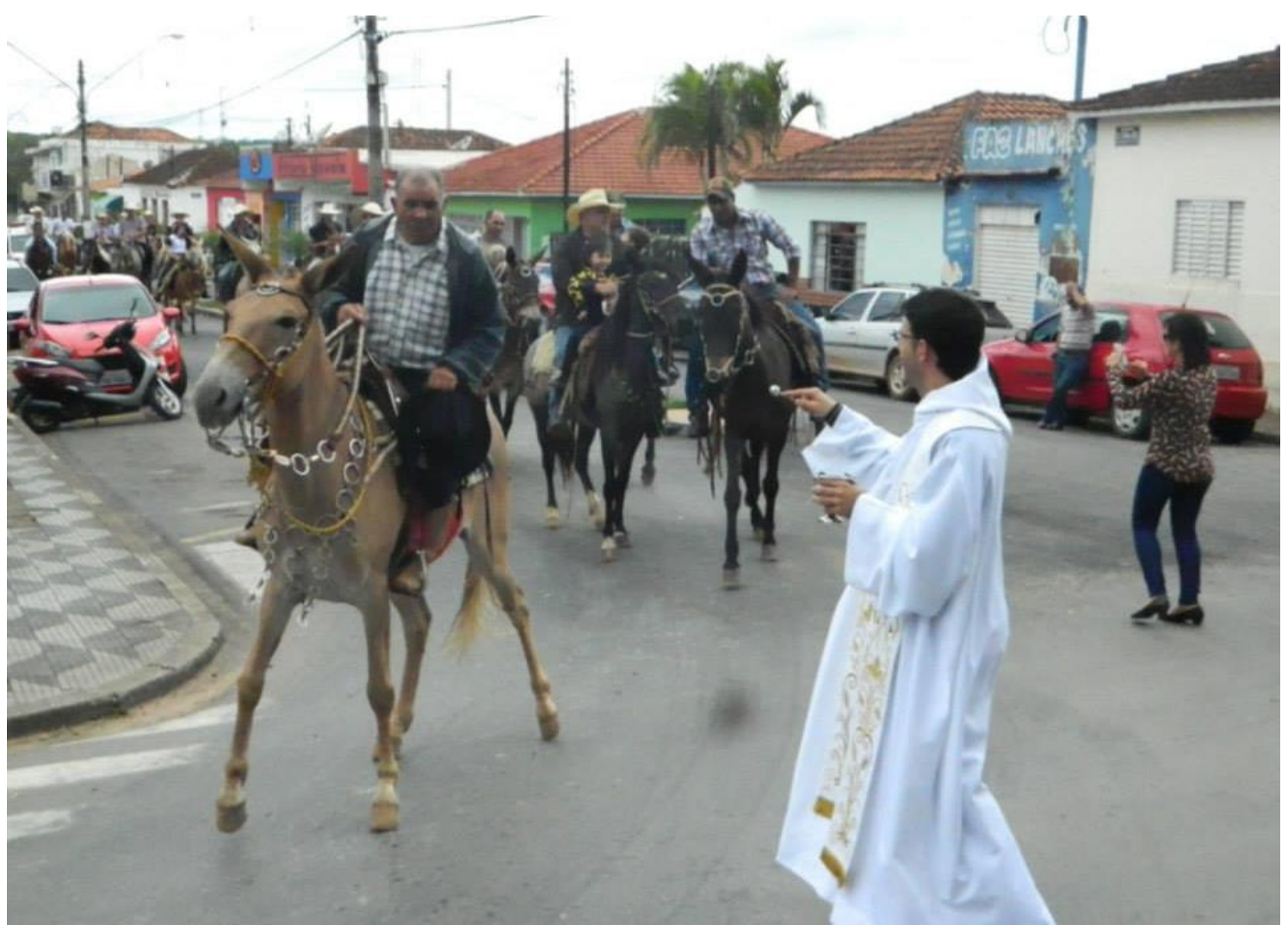

Foto 67: Chegada da cavalgada à cidade. No detalhe, Padre Cícero com a água benta. Foto: Arquivo digital da Paróquia Senhor Bom Jesus, 2015

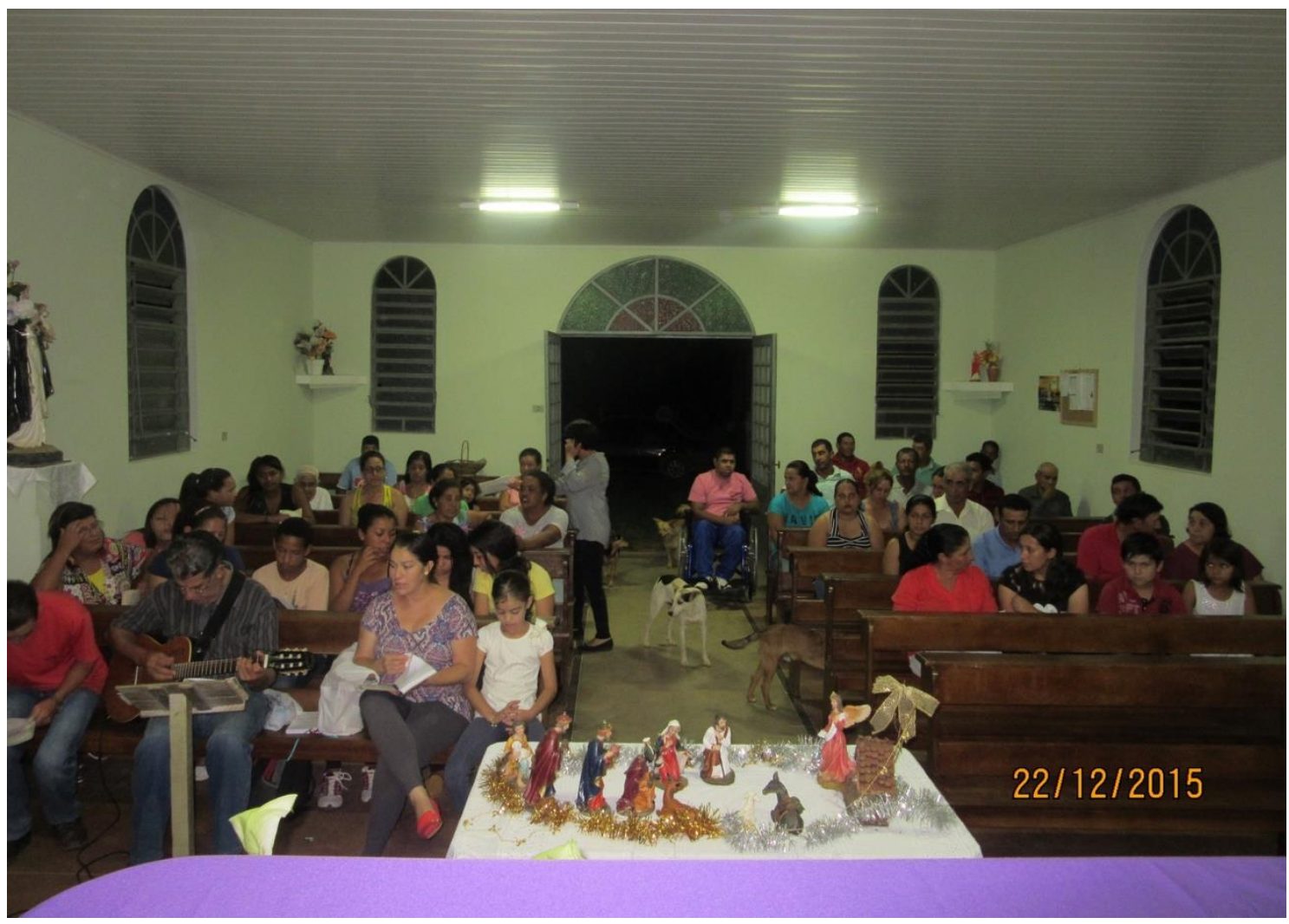

Foto 68: Último dia da novena de Natal na capela do bairro do Rio Apiaí. O presépio é montado no primeiro dia e permanece até o último dia da novena. Foto: Lucinei Paes de Lima, dez. 2015. 


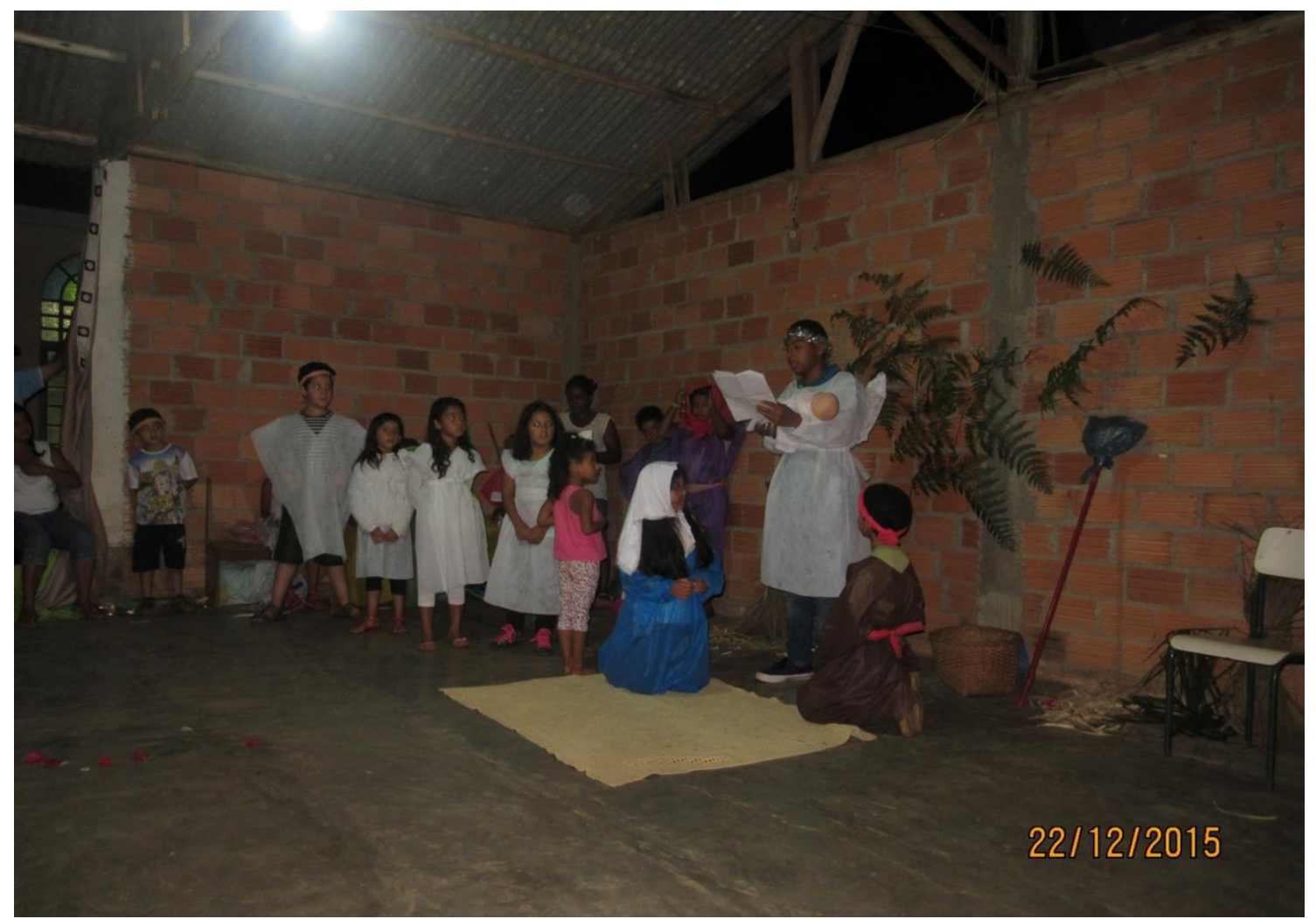

Foto 69: Peça de Natal apresentada pelas crianças do bairro do Rio Apiaí, sob a orientação cuidadosa da catequista Cheila. Foto: Lucinei Paes de Lima, dez. 2015.

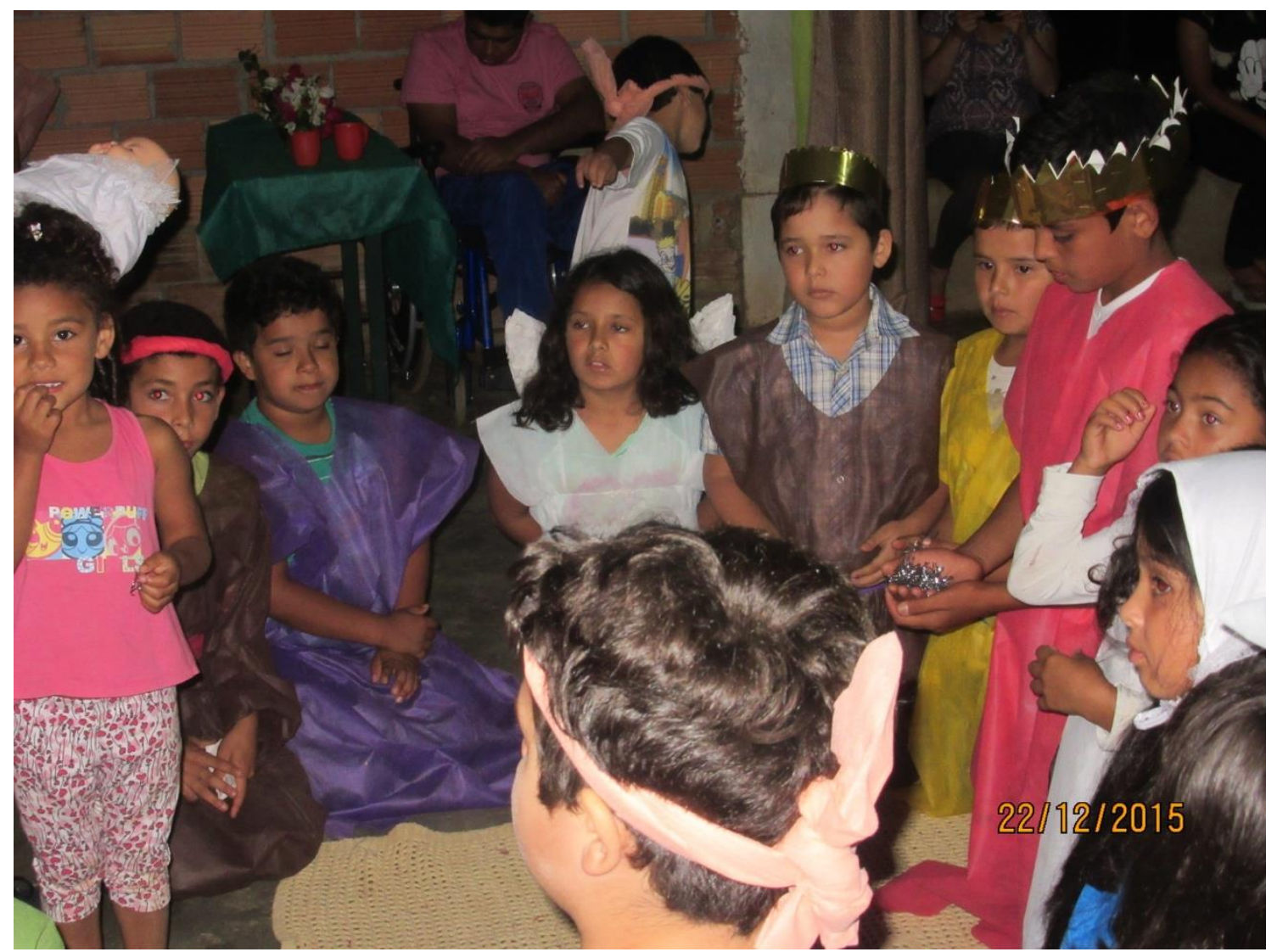

Foto 70: Peça de teatro sobre o nascimento de Jesus apresentada pelas crianças do bairro do Rio Apiaí. Foto: Lucinei Paes de Lima, dez. 2015. 


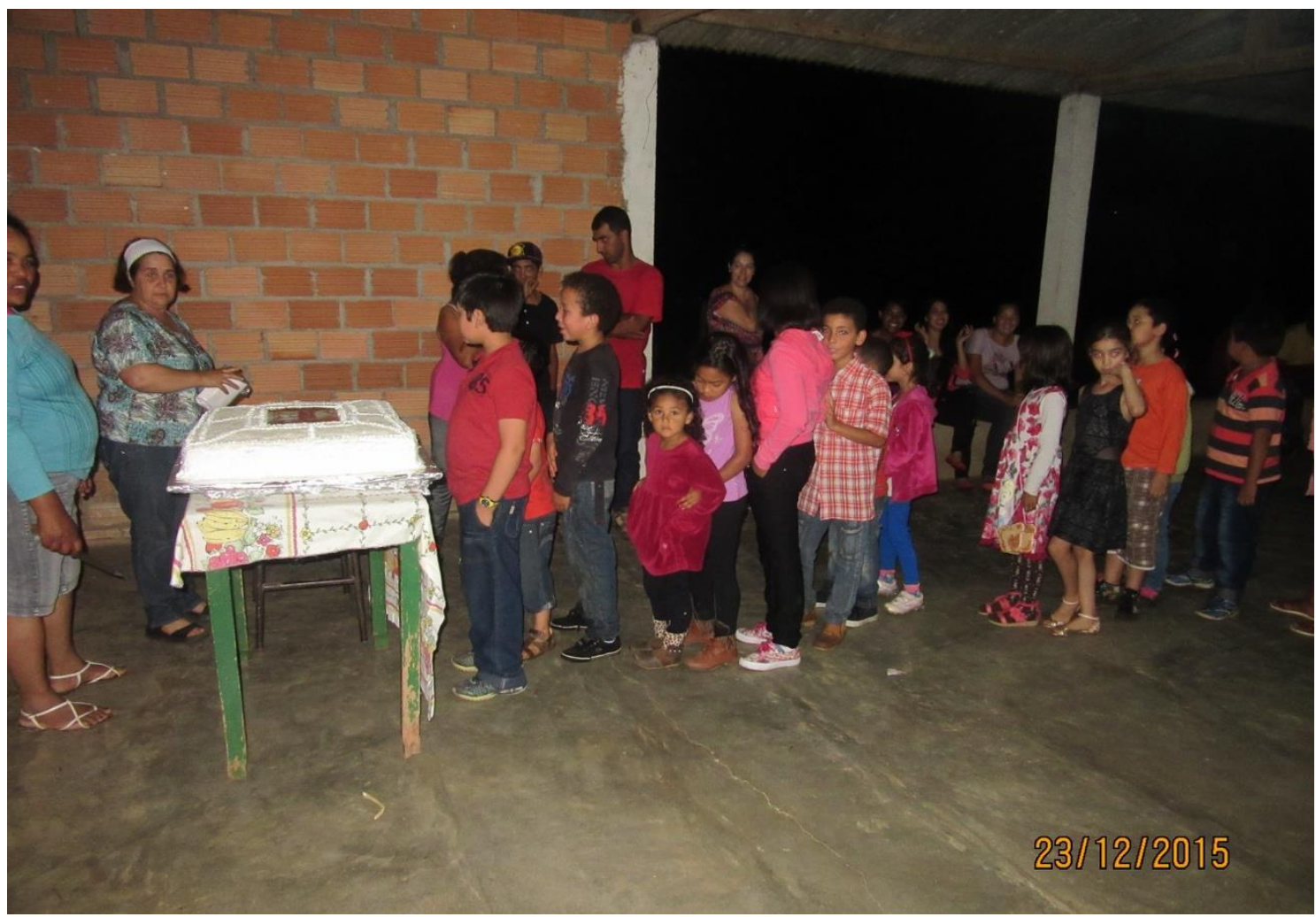

Foto 71: Confraternização no encerramento da novena de Natal do bairro do Rio Apiaí. As crianças são as primeiras a serem servidas. Foto: Lucinei Paes de Lima, dez. 2015.

Em Ribeirão Branco, ocorrem outras atividades religiosas além das já relatadas. Uma dessas atividades é a Romaria de São Gonçalo que, conforme nos informaram, acontece nos bairros do Batista, Água Branca, Capela de São Pedro e Rio Apiaí.

Sobre a Romaria de São Gonçalo, além de ouvirmos os relatos, também tivemos acesso a um documentário produzido pelo governo municipal, com apoio da Secretaria Estadual de Cultura de São Paulo, chamado A Dança de São Gonçalo - Ribeirão Branco (SÃO PAULO, 2013). Queiroz também analisou a Dança de São Gonçalo e, segundo a autora:

A Dança, por toda a parte onde encontrada, apresenta certos caracteres comuns. É sempre realizada diante de um altar, em que se acha a imagem de São Gonçalo, altar que é proibido dar as costas durante as evoluções. Os tocadores são sempre homens. Durante a Dança, são cantadas quadrinhas em louvor ao santo, agradecendo promessas satisfeitas ou formulando pedidos. Finalmente, durante a Dança ou terminada ela, um repasto final congrega os que dançam, os tocadores e o público. (QUEIROZ, 1973b, p. 138)

Os relatos em Ribeirão Branco sobre a Romaria de São Gonçalo são muito semelhantes ao que disse Queiroz. Também nos informaram que essa tradição já existe há cerca de quase um século no município. 
O Sr. Argemiro, do bairro da Água Branca, nos disse que participa da Romaria de São Gonçalo há mais de cinquenta anos. Ele o seu vizinho, Sr. José Carlos, são os violeiros mais procurados para as romarias nos bairros rurais do município. Além dos dois, as Sra. Pedra Conceição e Sra. Isabel Pereira, também do mesmo bairro, recebem convites para realizar a dança nos bairros vizinhos. Juntos, eles são os mais experientes, e os demais participantes observam e repetem os gestos e passos da dança.

A dança de S. Gonçalo, resultado sempre de um voto, é celebrada ali pelo menos uma vez por ano; os que dançam também cumprem promessas e, para que sejam válidas, é necessário que a cerimônia seja realizada na mais perfeita harmonia e ordem; o menor comportamento pouco respeitoso por parte de um assistente faz com que o rito perca todo o seu valor. (QUEIROZ, 1973a, p. 43)

A romaria também ocorre no bairro da Água Branca uma vez por ano e, segundo o Sr. Argemiro, eles realizam a dança com muito rigor e respeito. Ele nos disse que antigamente ela acontecia sempre pela noite e, no inverno, acendiam uma fogueira para aquecer o ambiente. Agora preferem realizar durante o dia para facilitar o trabalho das cozinheiras, que precisam fazer comida suficiente para alimentar todos os participantes.

O Sr. Argemiro também nos explicou como é feita a dança, que congrega, em média, de 150 a 200 pessoas cada vez que acontece:

A dança é dividida em rodeadas em frente ao altar do santo e nós, os violeiros, é que comandamos o ritmo. Dependendo da quantidade certa de pessoas, cada rodada pode demorar até uma hora, como são quatro rodadas, então você vê que vai ficar até muito tarde.

Formam-se duas filas em frente ao altar e, quando chega perto do altar, quem está atrás segue quem está na sua frente, e sempre quem está na frente é aquele que sabe mais. Então, quando tem gente nova, a gente explica que tem que olhar bem quem está na frente e já vai aprendendo, não fica com medo de errar na sua vez. São sempre duas pessoas por conta das duas filas, os dois têm que executar ao mesmo tempo aquela coreografia.

Eu queria mesmo é ver os jovens continuando essa tradição que é uma tradição de quem mora no mato, de gente muito simples, e não podemos deixar isso cair. (Entrevista com Argemiro, 7 jan. 2016)

Segundo o Sr. Argemiro, as pessoas que vão dançar têm que levar tudo muito a sério e não pode ficar olhando para o lado porque é muita falta de educação não prestar atenção em quem está realizando a dança. Esse comportamento também foi observado por Queiroz:

Regras severas regulam o comportamento dos executantes e do público durante a Dança. As dançadeiras não podem sorrir enquanto "trabalham", tem de olhar para a frente ou para o chão, sérias e compenetradas. Não se admitem requebros, nem nenhuma mudança no passo ou na figura. Não podem conversar umas com as outras durante os intervalos, nem com o público, e nem este entre si. São expressamente proibidos o fumo, a bebida, os namoros 
e as disputas durante toda a realização da Dança, pois tudo isso torna a cerimônia inteiramente sem valor. (QUEIROZ, 1973b, p. 147)

Não foi possível acompanhar nenhuma Dança de São Gonçalo. Porém, um pouco antes de um de nossos trabalhos de campo aconteceu uma dessas "danças" no bairro do Rio Apiaí. De acordo com alguns participantes, havia cerca de trezentas pessoas e a dança foi iniciada às 10 horas da manhã e encerrada às 17 horas. Foi servido aos participantes carne de panela com batata, arroz, feijão e salada. No ano anterior, foi servido sopa de mandioca com carne de boi, além do café, que é servido antes ou depois da dança.

\subsection{O futebol}

Nos bairros rurais de Ribeirão Branco, outra prática de socialização é a do jogo de futebol aos domingos. Geralmente, um bairro recebe um time de um bairro vizinho e os anfitriões se encarregam de dar uma quantia em dinheiro (média de 60 reais) para contribuir com o transporte do time visitante. Essa quantia é chamada por eles de "garantia", e é literalmente uma forma de garantir que o time visitado irá devolver a visita e tomar esse valor de volta. Segundo Paulino, o futebol é um ponto de encontro e proximidade entre os camponeses:

Outro ponto de encontro e fator de proximidade dos camponeses é o campo de futebol, ativo em muitos bairros rurais. Diríamos que, do ponto de vista do lazer, esse é o espaço mais importante das comunidades. É para esse local que a maior parte dos moradores converge nos domingos à tarde, sem distinção de idade e gênero. (PAULINO, 2012, p. 368)

Conversamos com os responsáveis pela organização dos times de futebol masculino e feminino do bairro do Rio Apiaí, os irmãos Claudinei e Claudinéia Souza. Claudinei nos deu o seguinte depoimento:

O futebol aqui no município é assim, cada bairro rural tem um responsável, como um dirigente do time do seu bairro, e a gente consegue fazer esse intercâmbio pra marcar os jogos.

Geralmente, a gente se encontra na cidade na segunda-feira, quando todo mundo vai pra cidade resolver coisas, e aí marca, combina jogos pro mês inteiro. Aqui no bairro tem jogo nos quatro domingos do mês porque é o lazer nosso.

Aqui, no Rio Apiaí, existe uma associação e cada jogador paga 10 reais por mês pra jogar. É com esse dinheiro que a gente mantém o time e também mantém um dinheiro em caixa para pagar a garantia pro time visitante.

Então a gente paga pra jogar. No dia do jogo, fazemos bolinhos e vendemos refrigerante no campo pra arrecadar dinheiro pro time.

No período de safra tem mais dificuldade porque todo mundo está com muito pouco tempo e não vai jogar muito longe, mas jogo tem do mesmo jeito, só que mais perto de casa. 
Eu acho que a prefeitura deveria de ter um programa pra ajudar os times rurais, tipo criar uma organização e apoiar. Por exemplo, falam que os ônibus da prefeitura não podem colocar pra transportar jogadores nos finais de semana, mas eu acredito que poderia ter um vereador que apresentasse na câmara um projeto, pois nos finais de semana não tem aula, então os ônibus escolares poderiam levar a gente pra jogar bola! Sabemos que não dá pra fazer pra todo mundo porque é muito bairro no município, mas poderia fazer tipo uma escala e a cada final de semana seria um diferente até acabar todos, assim já seria um grande apoio. Cada bairro poderia se organizar mais e ficaria melhor... mais organizado, pois a gente faz torneio e festinhas, mas o dinheiro sempre é pouco. Então não dá pra ir muito longe porque é caro!

Pra você ter uma ideia o quanto o jogo de bola é importante pro bairro, se não tiver no bairro uma venda, uma igreja e um campo pra jogar bola, não dá pra morar ali! (Entrevista com Claudinei Souza, 4 jan. 2016)

Quando Claudinei diz que "se não tiver no bairro uma venda, uma igreja e um campo de futebol não dá pra morar ali”, ele está definindo os pontos principais do bairro rural e a sua importância na vida dos camponeses. Esses são os locais que garantem a socialização e a diversão, são onde as pessoas sabem notícias dos vizinhos e, muitas vezes, onde são combinados os mutirões ou trocas de dias de serviço. No outro trecho do depoimento, Claudinei relata a disputa pelo espaço do campo de futebol no seu bairro:

Pra você ter uma ideia do quanto é complicado o negócio de mexer com jogo de bola, o espaço que o campo de futebol ocupa no centro do bairro é sempre um problema!

Na maioria dos bairros, o lugar do campo é sempre motivo de intrigas com o dono da terra que insiste em tirá-lo dali e aí é um movimento de briga. Aqui no bairro do Rio Apiaí não foi diferente, havia um campo em frente à igreja e o fazendeiro um dia resolveu passar o trator e acabou com o campo.

Então fomos pra outro lugar, pegamos um pedacinho em outra fazenda e de novo teve briga, pediram pra sairmos e as ameaças eram direto. Aí a gente pagou pra cercar, plantamos grama da boa e investimos pra deixar tudo certinho, então, com o tempo, todos do bairro ajudaram com dinheiro e até iam molhar a grama pra ela formar direitinho. O gerente da fazenda onde ficava o campo falava de passar o gradão ali, dizia que tinha raiva porque tinha alguns jogadores que eram do sindicato e eles não aceitavam muito tudo isso. E falava pra nós que ia passar o trator ali e plantar tomate em cima.

Ocorreu que o fazendeiro tava precisando regularizar as suas terras, que incluía o campo, e necessitava que os confrontantes assinassem o documento atestando que aquilo era dele. Então foi onde nós dissemos que, como os confrontantes eram a favor do campo, só assinavam se passasse aquele pedaço do campo pro time do bairro.

A advogada do fazendeiro veio e nós dissemos que não ia assinar se não fosse assim. Não tiveram saída e fizeram o papel passando pra nós.

Você pense, pra um fazendeiro que tem tanta terra, o que é aquele pedacinho ali de terra? E outros bairros sofrem com isso também! O bairro do Capote é um deles! (Idem)

Toda a família do Claudinei é envolvida com o futebol do bairro. A sua irmã, Claudinéia

Souza, organiza o time feminino: 
Eu jogo futebol de campo e de salão, e tem a época de campeonatos, aí tem que ir organizando e a gente fica desde cedo só ligando pra todo mundo e organizando pra tudo dar certo.

O futebol de campo feminino aqui do bairro era famoso, mas agora está cada vez mais difícil, pois precisa de onze meninas pelo menos e as meninas de hoje casam e vão largando mão de jogar, isso atrapalha muito o time. Mas ainda assim a gente tem jogado futebol de campo, pelo menos uma vez por mês tem que ter um jogo amistoso. Já o jogo de salão é mais direto, é toda a semana.

Quando os homens vão jogar num bairro onde tem time feminino, também aproveitamos e vai os dois times junto, masculino e feminino.

Mas o mais difícil mesmo é pagar o transporte pra gente ir jogar. Não tem apoio nenhum, nem mesmo para utilizar a estrutura da cidade! Os homens têm prioridade e nós mulheres temos horários diferentes por conta dos filhos, da casa, e os homens são mais livres depois do trabalho deles. Então, eles [os administradores dos horários das quadras de esportes] não priorizam isso e tudo é mais difícil pra nós. Mas, a gente corre atrás, sabemos que é direito nosso também usar aquilo ali. Ainda assim as meninas têm jogado tipo uns três jogos por mês no mínimo! Temos se virado!

Aqui no bairro começou com o meu pai e com o seu Jeca Silvestre, eles iam treinar a gente. O seu Jeca queria que as meninas do bairro ficassem boas de bola e sempre torceu muito pra nós!

As meninas do bairro sempre foram muito unidas. Antigamente, queriam jogar bola e ninguém conseguia impedir! Tinha uma época que quem levava a gente era o dono da venda do bairro, Seu Luiz, ele tinha uma caminhonete e a gente ia em cima. Então, chegava o dia de jogar e a gente ia pra frente da venda dele para intimidar o povo que estava bebendo pinga ali. Precisava eles irem embora para o dono da venda fechar e nos levar pra jogar!

Hoje em dia, as meninas parece que não querem mais essas coisas. Nesse tempo era o que a gente mais gostava, queria ganhar o jogo e isso motivava a gente a trabalhar duro na roça e ainda ir cansadas pra jogar... não era fácil, a gente ia até de trator jogar bola! Hoje em dia todo mundo só quer ver a TV e internet!

Hoje em dia os jovens não se interessam de formar um time bom no seu bairro, parece que não tem aquele interesse, sabe? Fica só no seu mundo!

Eu continuo jogando bola porque isso me traz muita alegria! $\mathrm{E}$ tem meu pai que, ainda com 82 anos, está aí marcando jogo, e a família ficou meio que com essa tarefa no bairro. Então às vezes é também uma necessidade dá gente continuar pra ter lazer sempre nessa parte no bairro. Ali a gente faz tanta amizade, conversa, dá risada, e os mais jovens arrumam namorado, e isso é bom pro bairro. (Entrevista com Claudinéia Souza, 4 jan. 2016)

Claudinéia fala sobre os desafios das mulheres em relação à falta de igualdade de oportunidades para jogar futebol. Segundo ela, o uso da televisão e da internet diminuiu o interesse das mulheres do bairro pelo futebol. Por fim, ela menciona a importância de manter essa tradição e o quanto essa atividade é importante para o encontro e lazer das pessoas. $\mathrm{Na}$ imagem abaixo, Claudinéia com seu esposo, sua filha, seu irmão Claudinei e seu sobrinho nos mostraram alguns dos troféus que o bairro ganhou nas competições de futebol. 


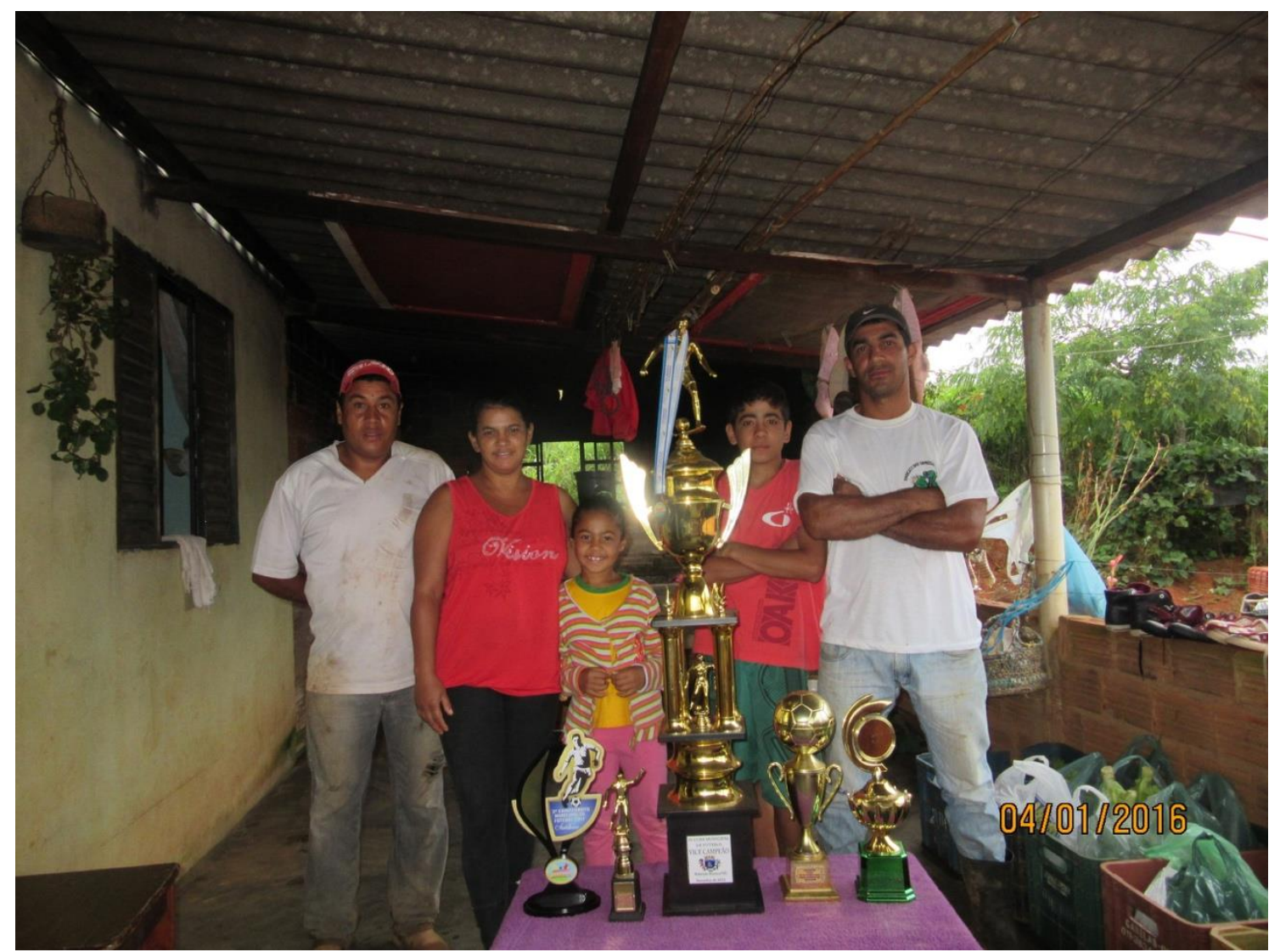

Foto 72: Claudinéia com seu marido e filha à esquerda e, à direita, seu irmão, Claudinei, e seu sobrinho, Rafael, exibindo os troféus que o bairro do Rio Apiaí ganhou nas competições. Foto: Lucinei Paes de Lima, jan. 2016.

Conforme relatado pelos irmãos, seu pai, Sr. Euriquinho, com seus 82 anos, ainda é capaz de caminhar longas distâncias para agendar jogos e garantir a diversão do domingo no bairro. Ele nos deu o seguinte depoimento sobre os times masculino e feminino do bairro do Rio Apiaí:

Olha, o time dos homens, teve uns times até mais ou menos, mas, o das meninas, teve um tempo que era muito melhor que o dos homens, não tinha time na região para ganhar dessas meninas. $\mathrm{O}$ time das meninas começou entre 1994 e 1995, tempo que tinha uma meninada aqui no bairro. As meninas ficaram muito boas de bola! A nossa goleira, Aline, até pegava penalidades. Tinha também a Judite, a Néia, a Luciane e as meninas do compadre Roberto e do Corintiano! Depois teve a Rosangela do Dominguinho também.

Olha, não tinha campeonato ou torneio que elas não trouxessem um troféu pro bairro. Você pode ir lá na venda do compadre Luiz e ver os troféus lá! Acontece que uma ajudava a outra no tempo das colheitas na roça pra dar tempo de jogar bola, uma ia passando na roça da outra pra ajudar a acabar o serviço logo e ia juntando tudo num lugar só as meninas. Tudo pra jogar bola! Teve um torneio no bairro do Santana ${ }^{[25]}$ e tinha um time muito bom de menina lá, era o melhor time da região, e o Rio Apiaí ia estrear nesse torneio. Aconteceu que ficou os dois times pra final, o nosso e esse time. O time deles

\footnotetext{
${ }^{25}$ Bairro rural do município de Guapiara.
} 
tinha até aquele massagista e o nosso, coitadas, tinha menina jogando até descalço!

Começou o jogo e, de repente, foi ficando de noite, e pro escuro não dá pra jogar bola. Então decidiram encerrar e resolver nas penalidades. Foi tanto gol naquele dia que nem lembro quanto foi, mas nós ganhamos o torneio! Ali foi o início de tudo, depois foram crescendo. (Entrevista com Euriquinho, 4 jan. 2016)

O Sr. Euriquinho fala com muito orgulho do time feminino que, segundo ele, trouxe muitas alegrias e animou muitos domingos do bairro. Ele mencionou a fato de elas saírem no dia do jogo e passarem nas casas das colegas que ainda estavam acabando a colheita para ajudar as companheiras a acabarem o trabalho mais rápido e irem para o campo de futebol. Ou seja, é um gesto solidário, uma característica do campesinato representada pelas mulheres do bairro que queriam jogar bola. Na Foto 73, o Sr. Euriquinho e sua esposa, Sra. Lourdes. Na sequência, imagens dos times feminino e masculino do bairro do Rio Apiaí.

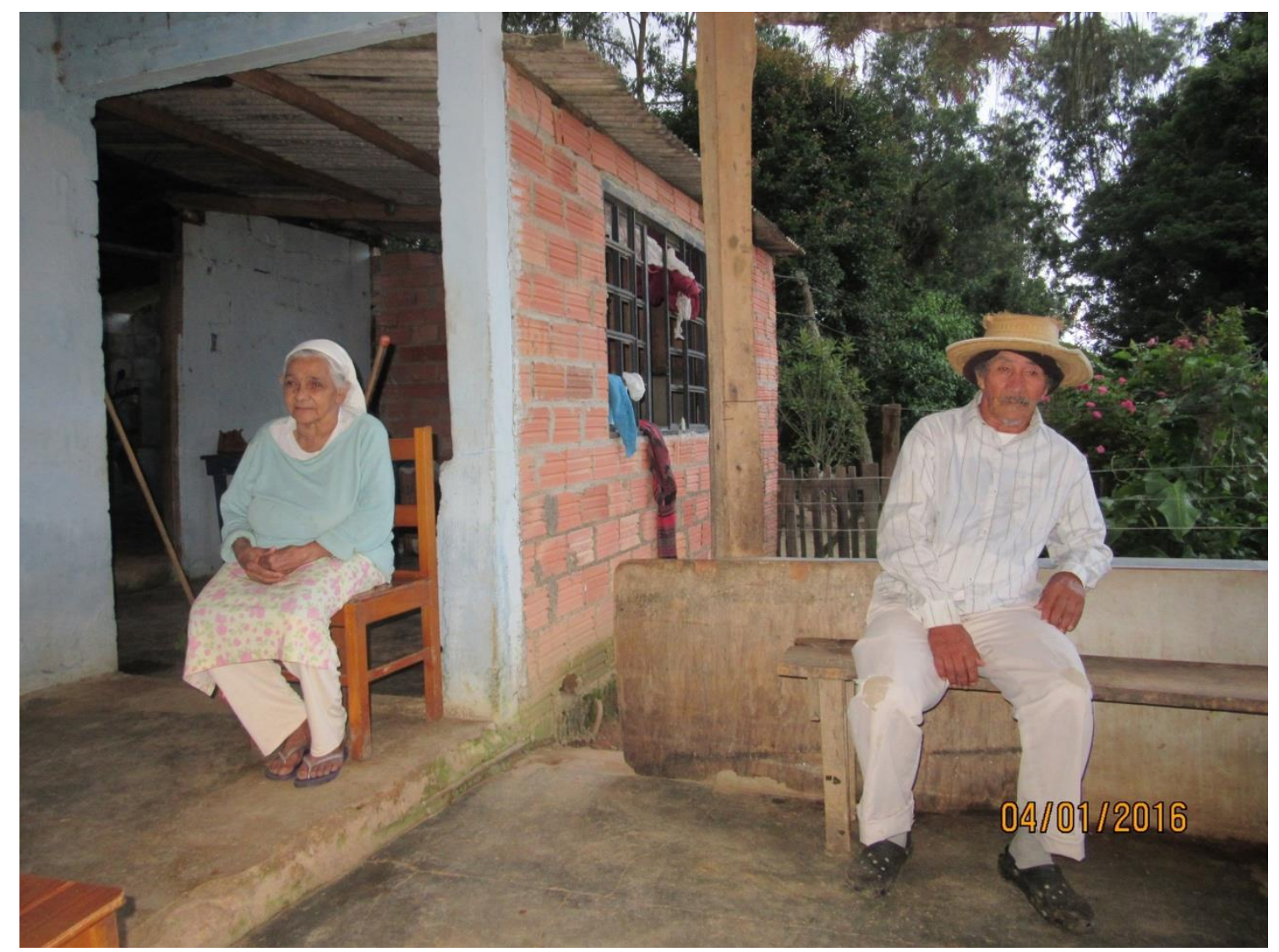

Foto 73: Sr. Euriquinho e sua esposa, dona Lourdes. Ele agenda jogos de futebol com bairros vizinhos. Bairro do Rio Apiaí. Foto: Lucinei Paes de Lima, jan. 2016. 


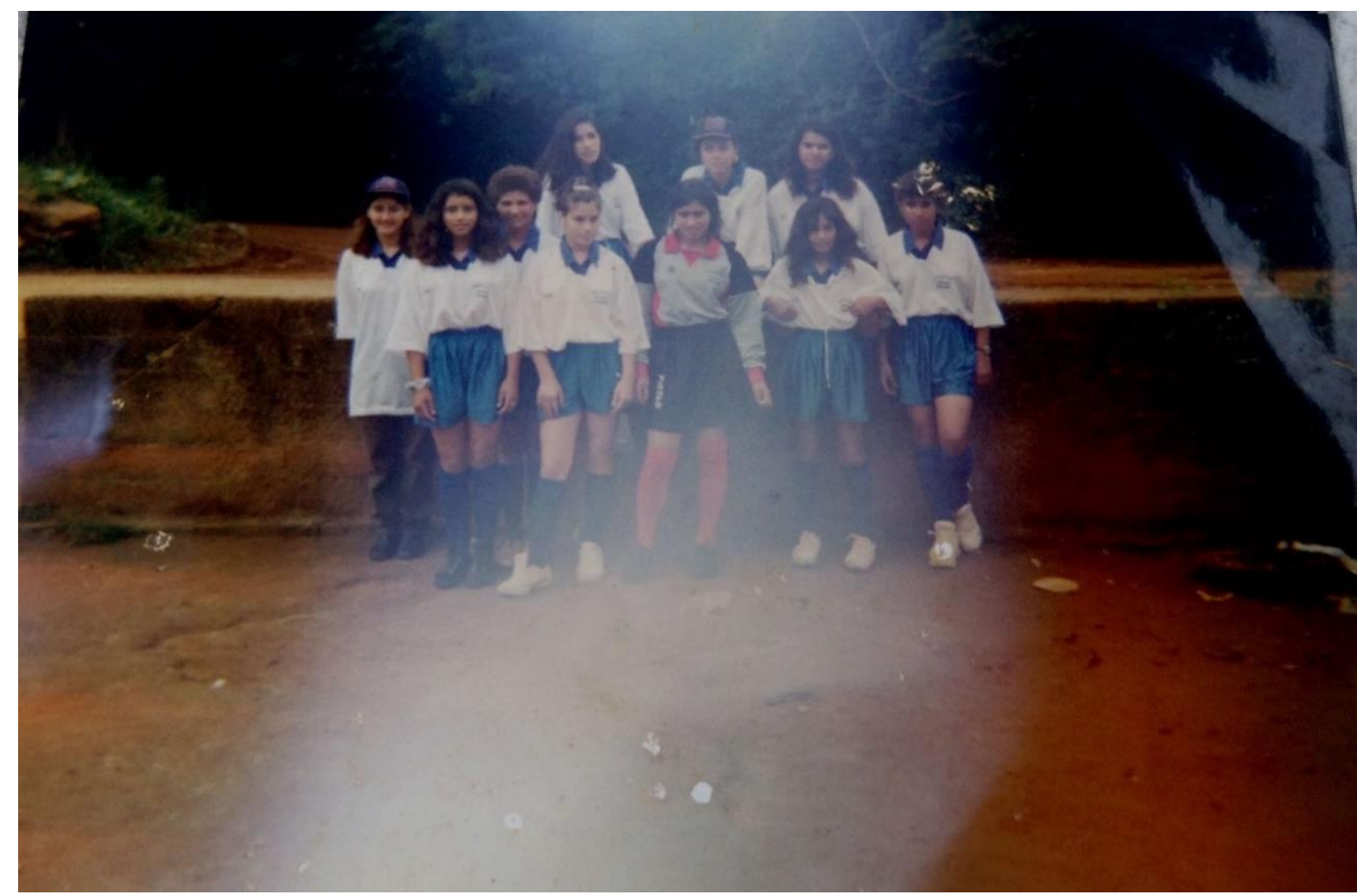

Foto 74: Primeiro time de futebol feminino do bairro do Rio Apiaí, 1995. Foto: Arquivo pessoal de Claudinéia Souza.

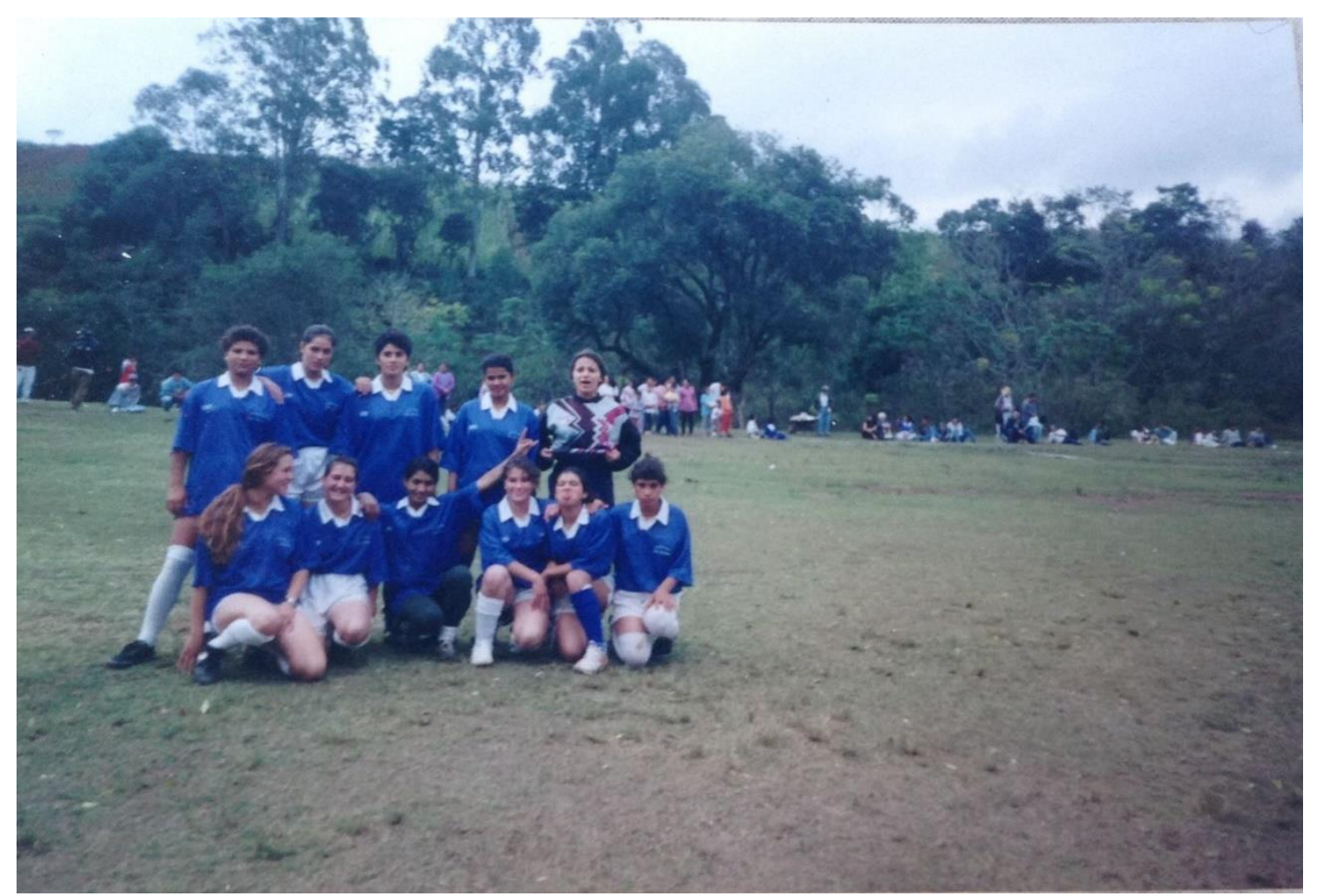

Foto 75: Time feminino do bairro do Rio Apiaí em 1997, torneio no bairro dos Paes. Foto: Arquivo pessoal de Claudinéia Souza. 


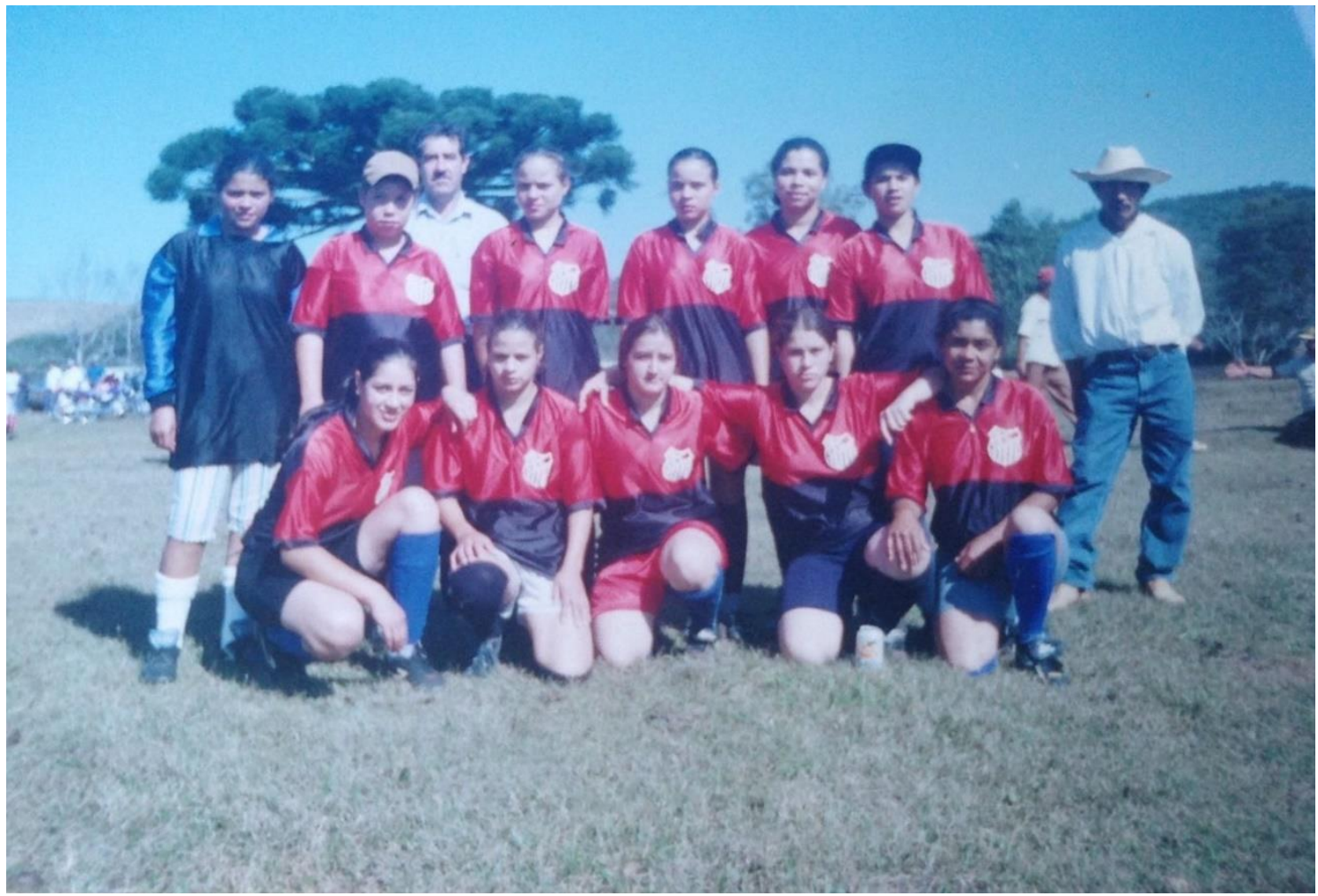

Foto 76: Time feminino do bairro do Rio Apiaí em 1998, torneio no bairro Capela de São Pedro. Sr. Euriquinho, à direita, e Sr. Luiz (dono da venda), ao fundo. Foto: Arquivo pessoal de Claudinéia Souza.

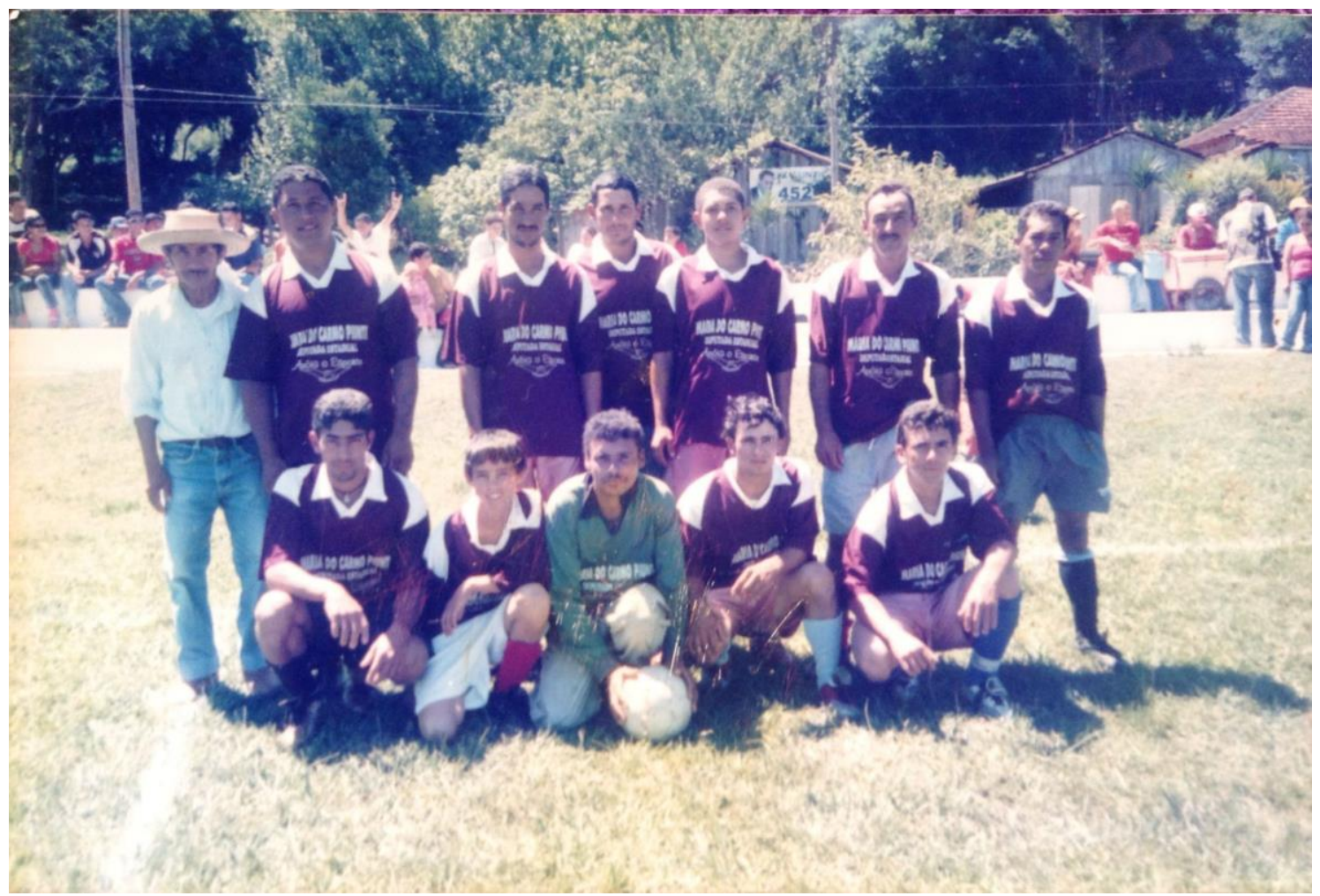

Foto 77: Sr. Euriquinho e o time de futebol masculino do bairro do Rio Apiaí em 1998. Foto: Arquivo pessoal de Claudinéia Souza. 


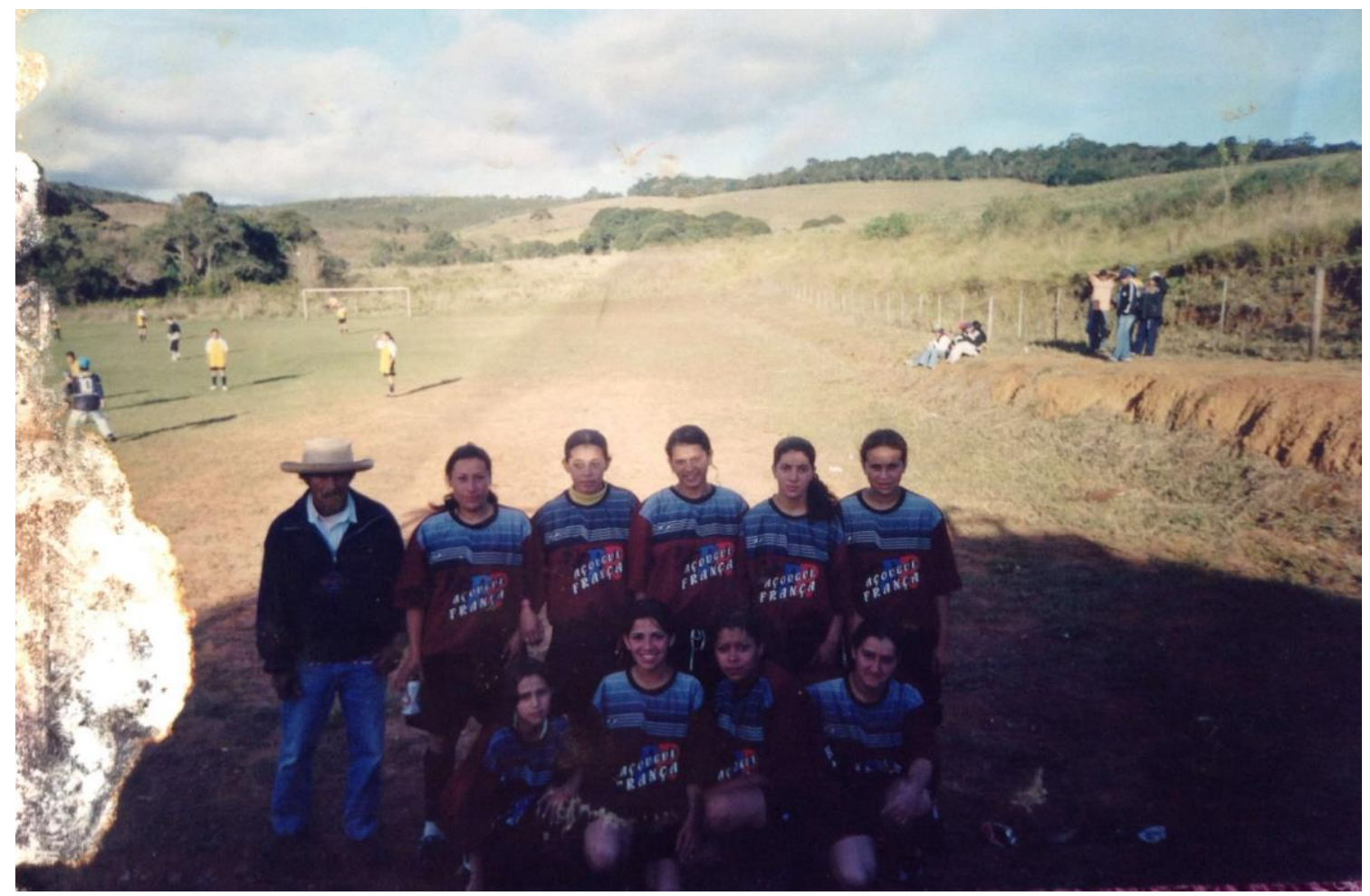

Foto 78: Time feminino do bairro do Rio Apiaí em 2006, amistoso no bairro do Rio Apiaí. Sr. Euriquinho, à esquerda. Foto: Arquivo pessoal de Claudinéia Souza.

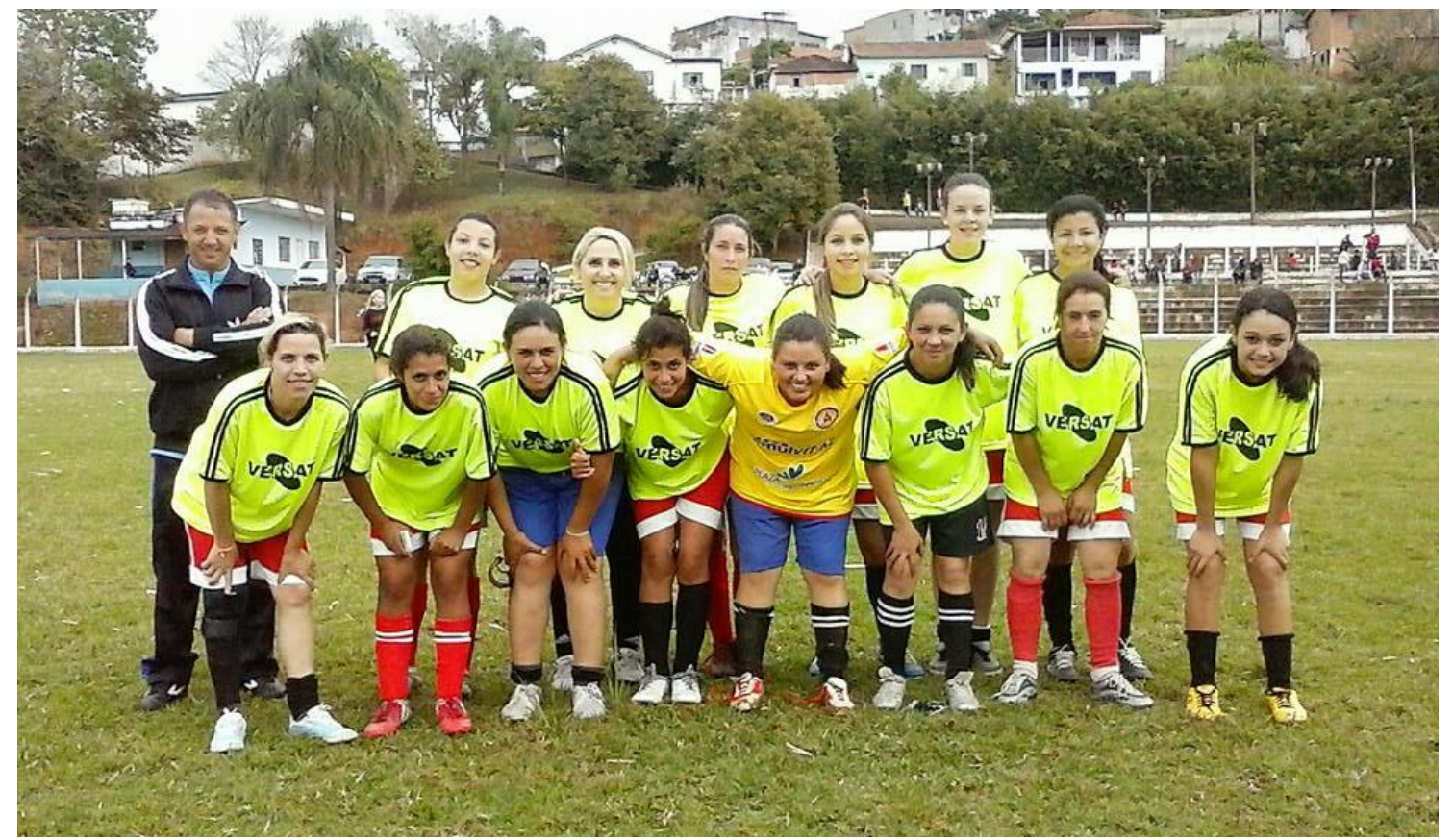

Foto 79: Time de futebol feminino do bairro do Cerrado, amistoso contra o bairro do Rio Apiaí em 2015. Estádio Municipal de Ribeirão Branco. Foto: Arquivo pessoal de Claudinéia Souza. 
Conforme foi apresentado aqui, o futebol exerce papel importante na vida dos camponeses de Ribeirão Branco e, embora tenham nos dito que a participação, principalmente das mulheres, diminuiu no futebol do bairro do Rio Apiaí, ele continua existindo como uma forma de lazer para elas.

Além do futebol e da religião, os camponeses de Ribeirão Branco também se envolvem e participam de outras atividades culturais e de geração de renda, como o artesanato, a Feira da Lua e o evento "Na roça também se faz cultura", este último patrocinado pela Diretoria de Cultura do Município, mas organizado pelas comunidades rurais. Falaremos um pouco mais de cada um deles seguir.

\subsection{O artesanato}

Sobre o artesanato, conversamos com a Sra. Fabiana, servidora municipal e responsável por catalogar e organizar a produção do artesanato para as feiras que acontecem em diversas regiões do estado de São Paulo. Ela é a responsável pela loja de artesanato da cidade.

Fabiana nos relatou que o artesanato de Ribeirão Branco prioriza o trabalho feito de palha de milho e fibra de taboa ${ }^{26}$. Segundo Fabiana, os produtos têm melhorado muito nos últimos anos e ganhado destaque nas feiras que participam, onde costumam vender quase tudo que levam. O trabalho dos artesãos de Ribeirão Branco pode ser conferido na loja que fica no Terminal Rodoviário da cidade:

Aqui tem muitos que fazem artesanato, mas alguns se dedicam mais e esses são os que garantem o artesanato sempre renovado, tanto na lojinha quanto pra ir pras feiras. Os que mais fazem empenho de fazer coisas são uns 26 artesãos, esses são ponta firme mesmo, porque trabalham na roça, a maioria no tomate. E também a maioria são mesmo a mulherada, que são demais de esforçadas! (e pelas exposições e comércio em eventos. (Entrevista com Fabiana Almeida, 6 jan. 2016)

O artesanato é bem diversificado e se destaca pelo colorido das peças. Como nos disse a Sr. Fabiana, a maioria dos produtos é feita pelas mãos dos camponeses que moldam cada peça nos seus momentos de descanso do trabalho da roça.

\footnotetext{
${ }^{26}$ Assim como o junco, a taboa é uma planta emersa que cresce nas margens de lagoas e represas, sendo muito frequente em brejos e pântanos. Ela ocorre em toda a América tropical e subtropical. Suas longas folhas, de coloração verde, são utilizadas para a manufatura de esteiras de dormir, cestas e muitos outros utensílios. Apresenta grandes espigas marrons formadas por frutos de fibra lanulosa. Dela se aproveita a paina para enchimento de almofadas. Seu caule, muito rico em amido, após ser moído e tratado, produz um polvilho comestível (Cf. <http://www.ufscar.br/ probio/info_typha.html>. Acesso em: 29 jan. 2016).
} 
$\mathrm{O}$ artesanato é vendido nos eventos e feiras promovidos pelo governo do estado, o principal deles é o "Revelando São Paulo"27, que tem quatro edições anuais nas cidades de Atibaia, São José dos Campos, Iguape e São Paulo. Também são comercializados nas atividades que o município promove, como a "Feira da Lua" e o evento "Na Roça Também se Faz Cultura"28. Além disso, a produção artesanal de Ribeirão Branco fica exposta diariamente na loja mantida pela prefeitura.

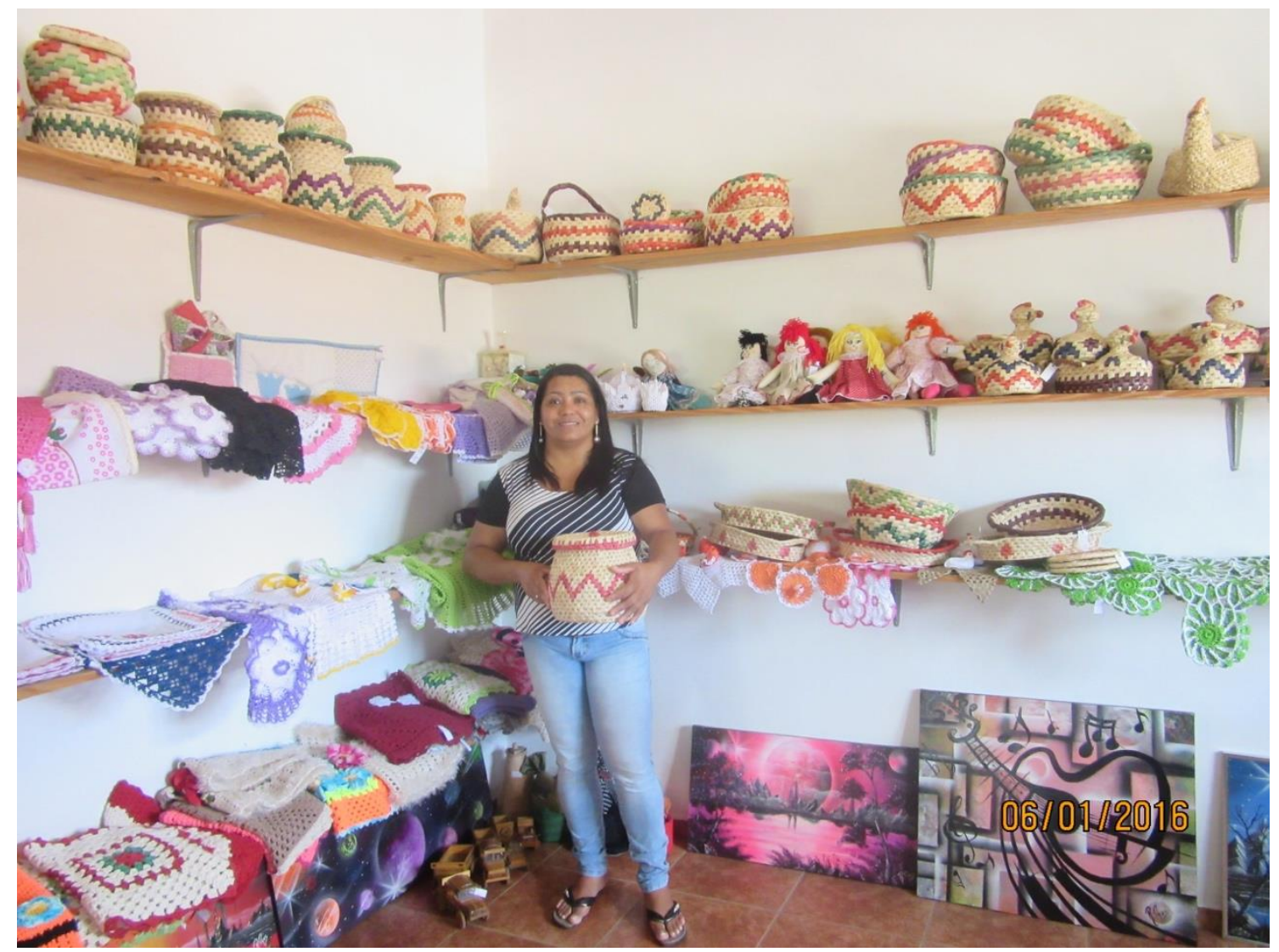

Foto 80: Fabiana Almeida na loja de artesanato municipal de Ribeirão Branco. Foto: Lucinei Paes de Lima, jan. 2016.

27 Sobre o "Revelando São Paulo", ver: <http://revelandosaopaulo.org.br/rv/wpcontent/uploads/2013/07/REVELANDO-SAO-PAULO-APRESENTACAO.pdf> <http://www.abacai.org.br/revelando.php>. Acesso em: 19 out. 2016.

${ }^{28}$ Trataremos desses eventos mais adiante. 


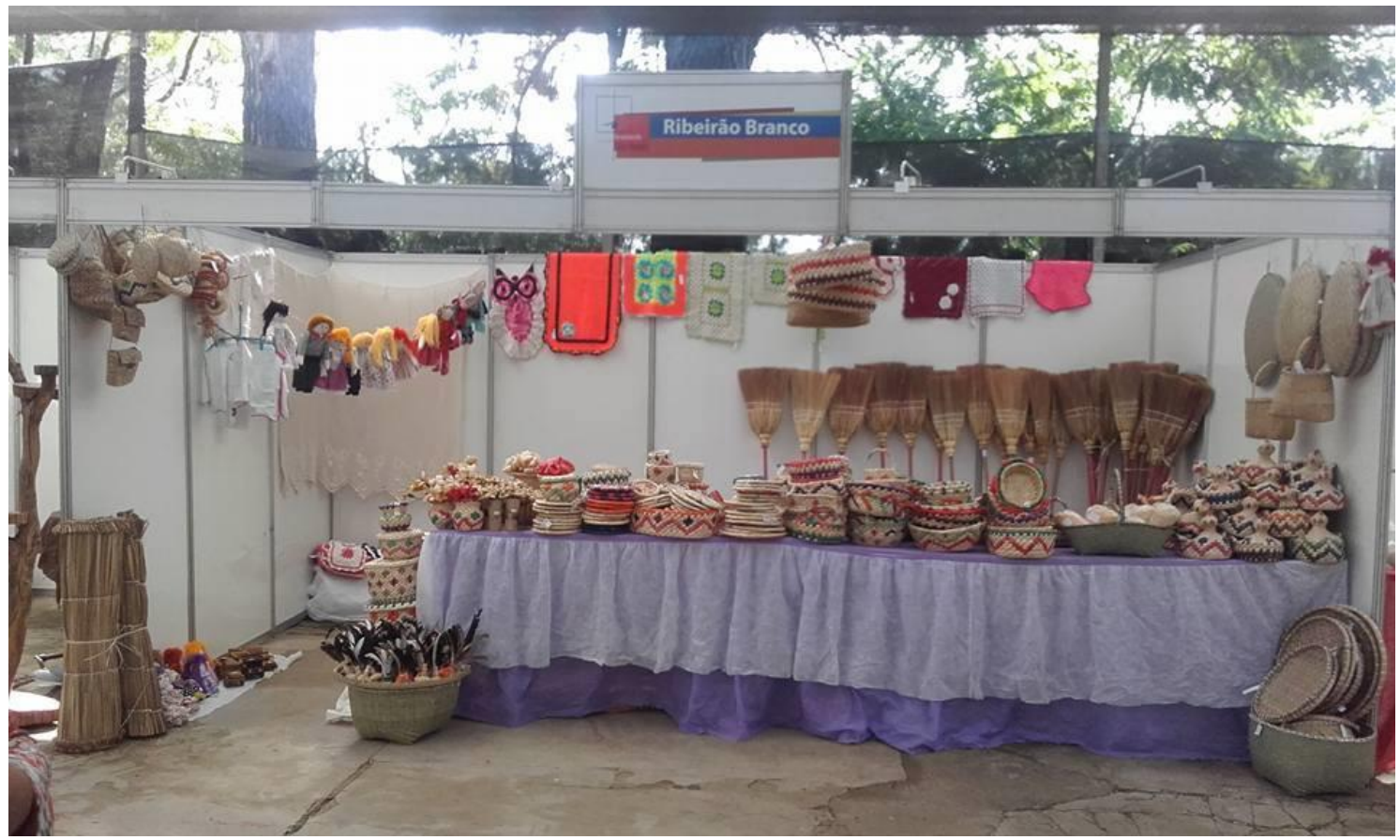

Foto 81: Exposição de Ribeirão Branco na feira de artesanato "Revelando São Paulo", 2015. Foto: João Luiz Ubaldo.
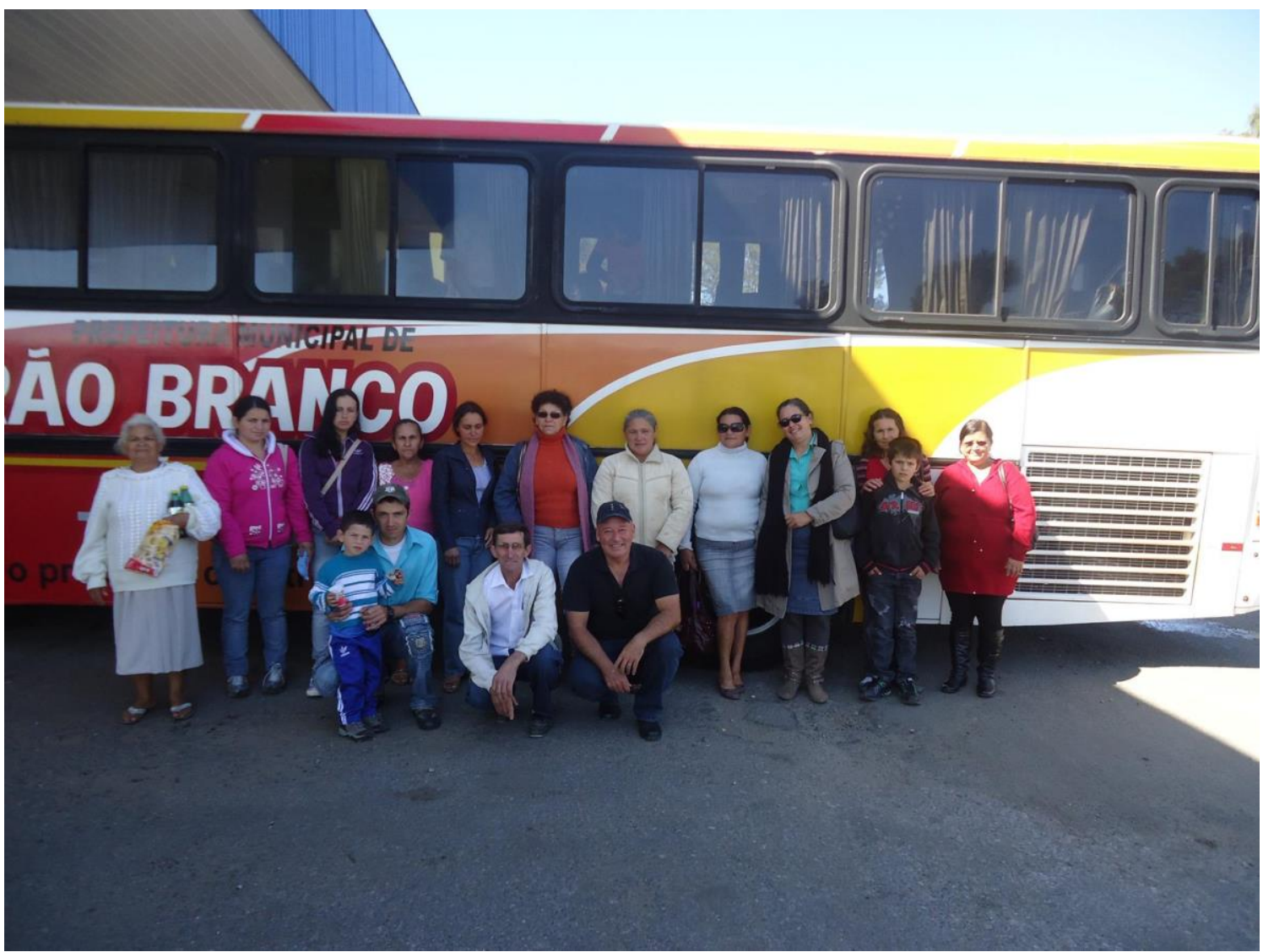

Foto 82: As mulheres são a maioria dos artesãos de Ribeirão Branco. Na imagem, o diretor de cultura, Sr. João Luiz Ubaldo (primeiro abaixado, da direita para a esquerda). Foto: Arquivo pessoal de João Luiz Ubaldo. 


\subsection{A Feira da Lua}

A Feira da Lua é uma atividade que tem como objetivo a criação de um ponto de encontro no centro da cidade. A sua primeira edição aconteceu no dia 6 de novemnbro de 2015 . A ideia dessa feira surgiu de uma visita às cidades de Avaré e Angatuba, onde existia projeto semelhante. Em Ribeirão Branco, a feira acontece todas as sextas-feiras na praça da Igreja matriz, das 16 às 23 horas.

É um ambiente onde as famílias se juntam para conversar, as crianças se reúnem para brincar e todos aproveitam para comprar os produtos dos camponeses e artesãos, além dos comes e bebes que são comercializados.

O diretor de cultura, Sr. João Luiz, e o secretário de agricultura do município, Sr. João Claudio, se encarregam de fornecer a estrutura necessária para a realização, e o sindicato de trabalhadores organiza os camponeses para venderem a sua produção na feira. Eles nos disseram que a feira é um sucesso e que as pessoas a têm frequentado como um espaço de lazer e encontro entre famílias.

A idéia da feira surgiu a partir do João Luiz, diretor de cultura que viu a feira na cidade de Avaré e me chamou para conversar. Achamos que se as entidades sociais topassem, a gente poderia implementar. Então falamos com os sindicatos e associações, com a igreja e o comércio, e todo mundo achou que poderia dar certo.

Fomos visitar outras feiras em outros lugares para termos mais idéias. Quando voltamos, colocamos em prática o projeto e está indo muito bem até agora!

A feira acontece toda sexta à noite. A população tem uma razão para sair de casa e vir na praça comer, beber e bater papo com os amigos. Acreditamos que estamos, com isso, possibilitando uma alternativa de lazer para a população e oportunidade de geração de renda para os agricultores familiares. (Entrevista com João Claudio, 8 jan. 2016)

Tivemos a oportunidade de visitar a Feira da Lua (Foto 83 a Foto 86). Na feira também é vendido o bolinho típico da região Sudoeste paulista, o "encapotado". Esse bolinho, que é frito, é feito com farinha de milho e recheado com frango desfiado e cheiro verde. Nos disseram que ele não pode faltar nas quermesses dos bairros rurais.

As donas das barracas nos disseram que estão muito satisfeitas com o projeto que proporcionou geração de renda para elas. Segundo nos informaram, a frequência é de 250 a 300 pessoas em cada edição da feira, o que garante público suficiente para todas as barracas. Além dessas barracas apresentadas, há a barraca da Sra. Nega, que faz o pastel, a barraca do bolinho de farinha de milho assado e outras, além das barracas que comercializam legumes, verduras e frutas. 


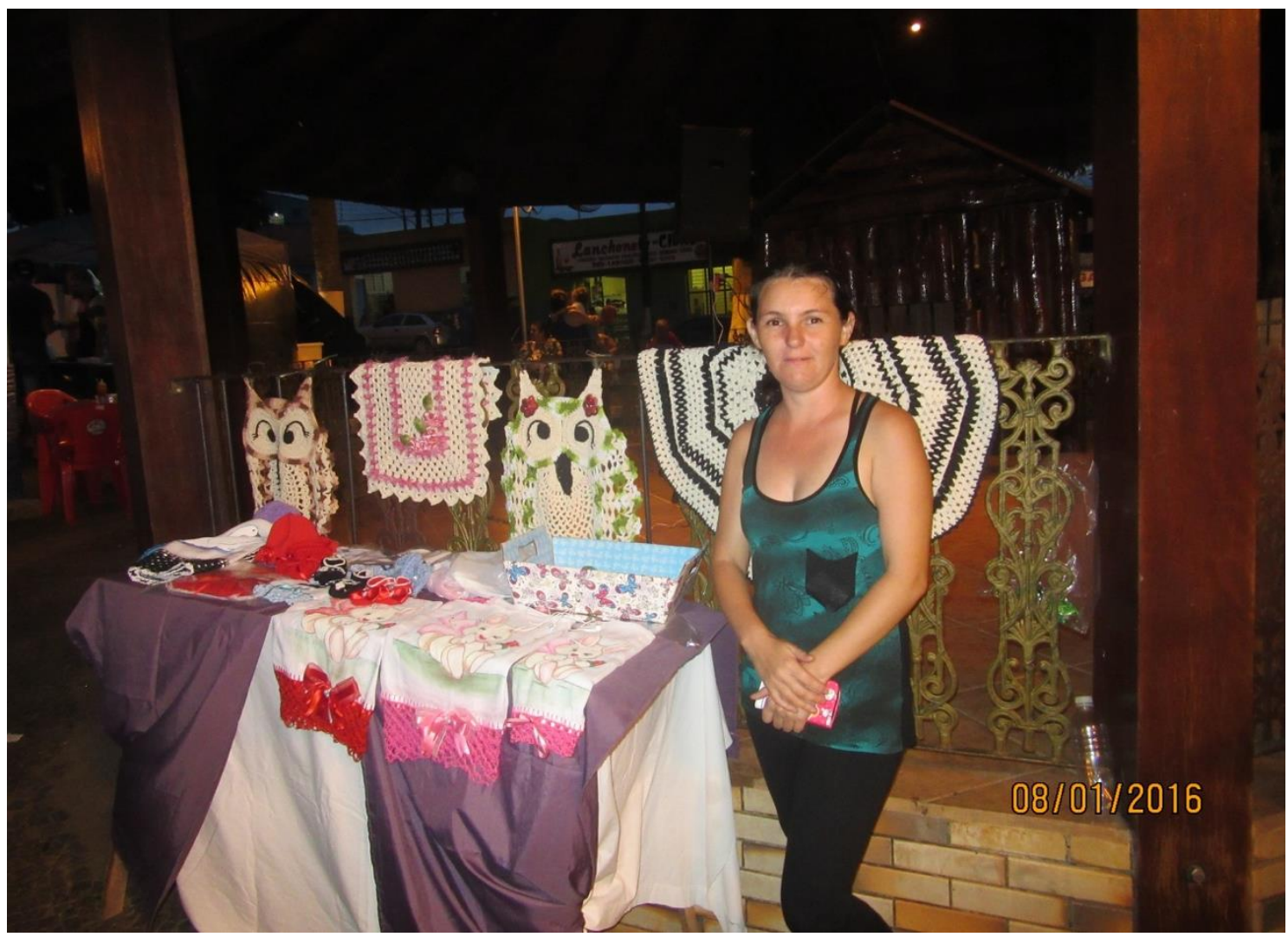

Foto 83: Vanuza, camponesa e artesã do bairro do Batista na Feira da Lua. Foto: Lucinei Paes de Lima, jan. 2016.

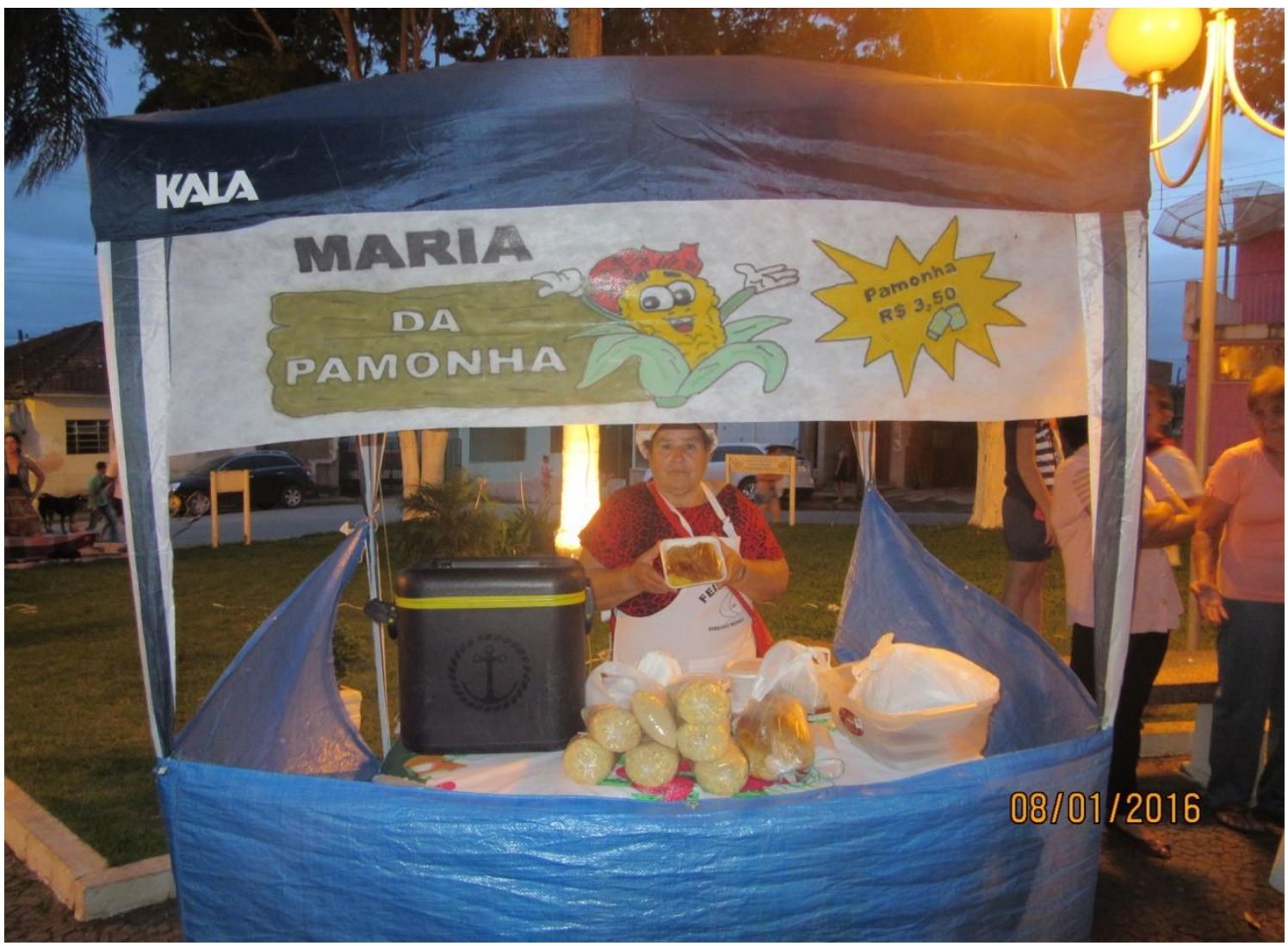

Foto 84: Barraca da Maria na Feira da Lua: toda a sua produção é de derivados do milho. Foto: Lucinei Paes de Lima, jan. 2016. 


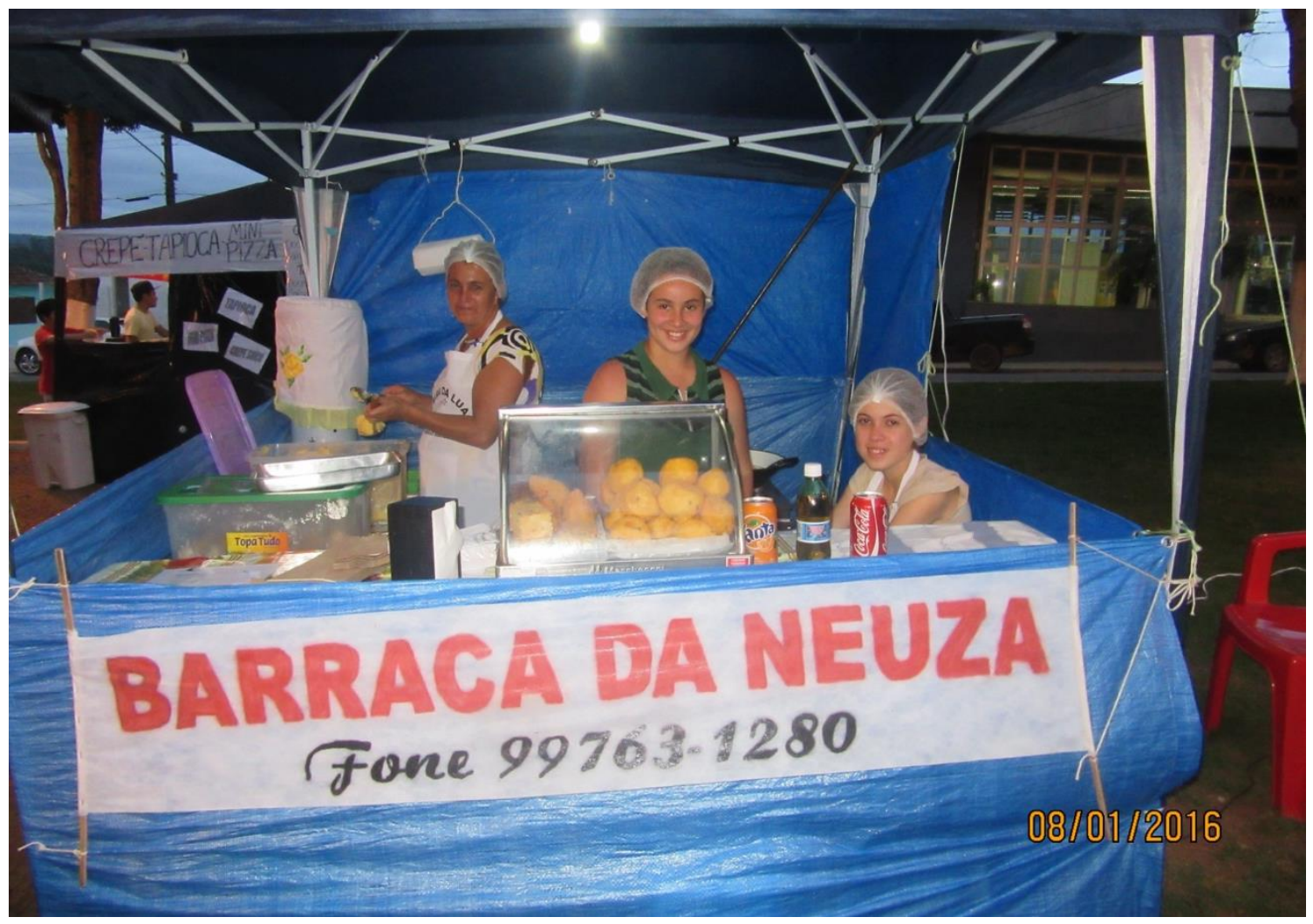

Foto 85: Barraca da Neuza que, com suas filhas, prepara o típico "encapotado" (bolinho frito de farinha de milho recheado de frango e cheiro verde). Foto: Lucinei Paes de Lima, jan. 2016.

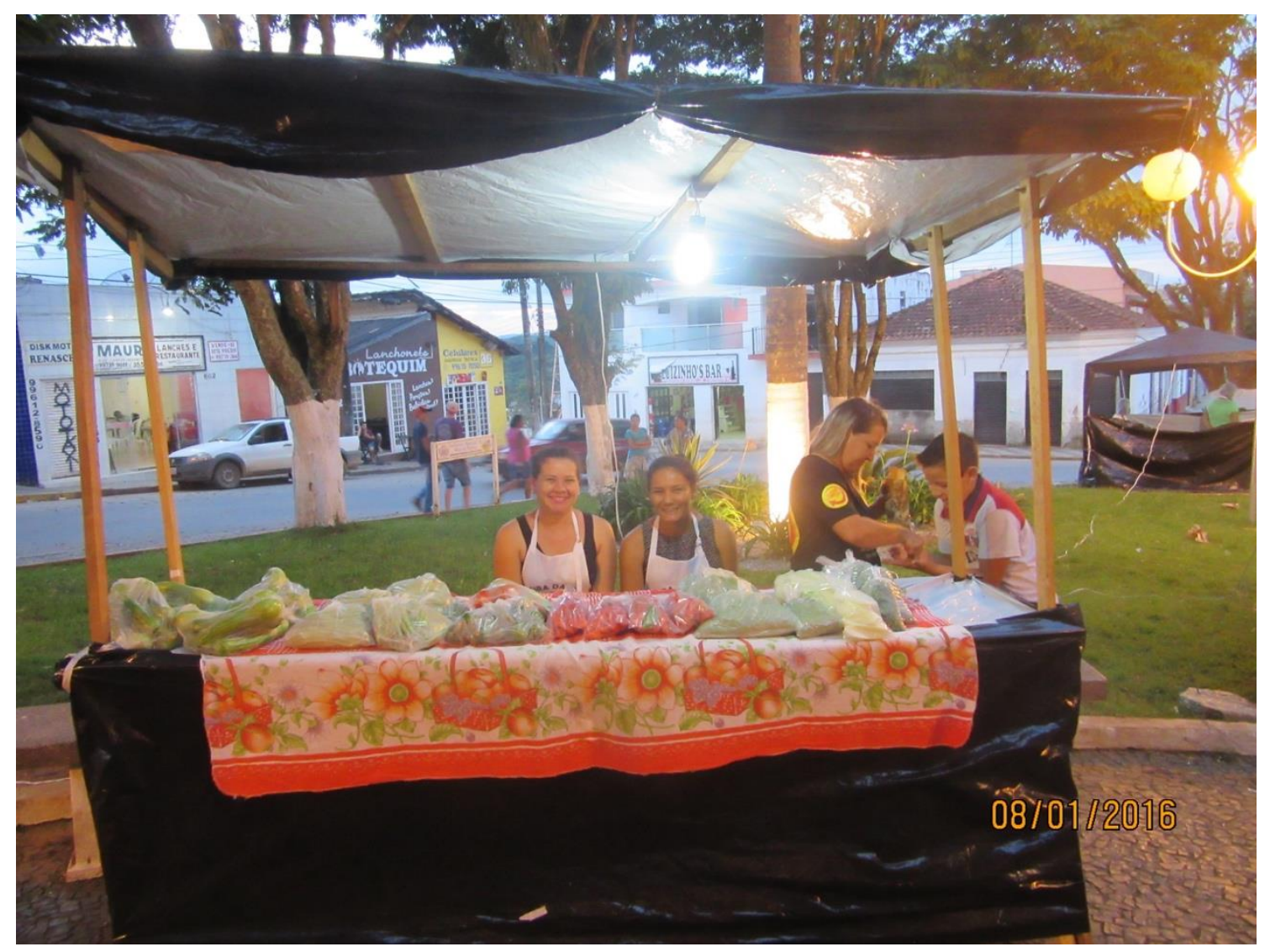

Foto 86: Barraca de verduras, legumes e frutas de Daiane de Souza e Aline Santos, camponesas do bairro do São Roque. Foto: Lucinei Paes de Lima, jan. 2016. 
Uma delas é a que vemos na Foto 86, onde falamos com Daiane Souza, camponesa do bairro São Roque. Na sua barraca tinha abobrinha, pimentão, chuchu, limão e cheiro verde entre outros produtos.

Outra atividade relatada pelos camponeses como espaço de encontro e lazer entre as pessoas do bairro, e também de bairros vizinhos, é o projeto "Na Roça também de faz Cultura".

\subsection{Projeto "Na Roça também se faz Cultura"}

De acordo com o diretor de cultura, Sr. João Luiz, esse projeto tem como objetivo criar oportunidade de lazer e cultura nos bairros rurais:

O nosso município é rural, a maioria das pessoas vive nas comunidades rurais e sempre ouvimos dizer que a administração não investia em atividades de lazer para essas pessoas.

Um dia estava pesquisando na internet e vi um cartaz com a frase "na roça também se faz cultura". A partir disso, fomos dialogar com algumas comunidades que vinham reivindicando atividades em seus bairros. Reunimos para conversar e discutir como poderíamos criar uma atividade cultural onde o povo da roça sentisse vontade de participar e ao mesmo tempo fosse um espaço de promoção da cultura do bairro e que revelasse a sua história de constituição, seus primeiros moradores, a construção da capela e essas coisas. Escolhemos o primeiro bairro e, em 2011, fizemos a primeira edição no bairro do Rio Apiaí. Foi um sucesso, depois não parou mais! Todos os bairros querem o projeto lá. O mais importante é que a gente leva a estrutura de cadeiras, palco, microfone e eles é que fazem a festa! Não é um projeto pronto, a gente se reúne e eles criam a programação. Hoje em dia eles pegam a gente na rua e já vão dizendo sobre os seus artistas que são músicos, contadores de piadas e histórias, dançarinos etc. Também levamos para o dia do espetáculo a nossa biblioteca itinerante, que fica disponível durante todo o dia, e ainda o artesanato, que é exposto no evento. O restante é tudo com eles! (Entrevista com João Luiz Ubaldo, 9 jan. 2016)

João Luiz nos contou que foi criada uma comissão de representantes dos bairros rurais e da Diretoria de Cultura, e que esse grupo se reúne para decidir em qual bairro será a próxima edição. Ele também nos disse que, no início, o projeto acontecia uma vez ao mês. Agora, por falta de recursos financeiros para som, montagem, estrutura de palco e transporte ${ }^{29}$, o projeto está sendo realizado uma vez a cada três meses.

As edições do projeto costumam receber cerca de 200 pessoas em média e, no dia do evento, há os comes e bebes preparados pela comunidade e também por visitantes de bairros

\footnotetext{
${ }^{29} \mathrm{O}$ transporte é utilizado para levar os moradores e artistas das comunidades vizinhas até o local da festa.
} 
vizinhos, vendem-se bolinhos, pamonhas, bolo doce, pão, pastel e outros salgados. O evento se inicia às 14 e se encerra às 19 horas.

As festas da cultura na roça são muito animadas e servem, como estímulo para resgatar o costume das pessoas de se encontrarem para bater papo.

No domingo, estão deixando de se visitar e ficam vendo TV. Então, se tem a festa, todo mundo se encontra pra conversar, ouvir música e até dançar. (Idem)

Ao final do evento, sempre é exibido um filme que conta a história do bairro, apresentando fotografias antigas dos moradores, festas que a comunidade organiza e também imagens que retratam os momentos da preparação do evento. Da Foto 87 a Foto 93, temos alguns dos momentos da edição desse projeto realizada no bairro da Capela de São Pedro, em junho de 2015.

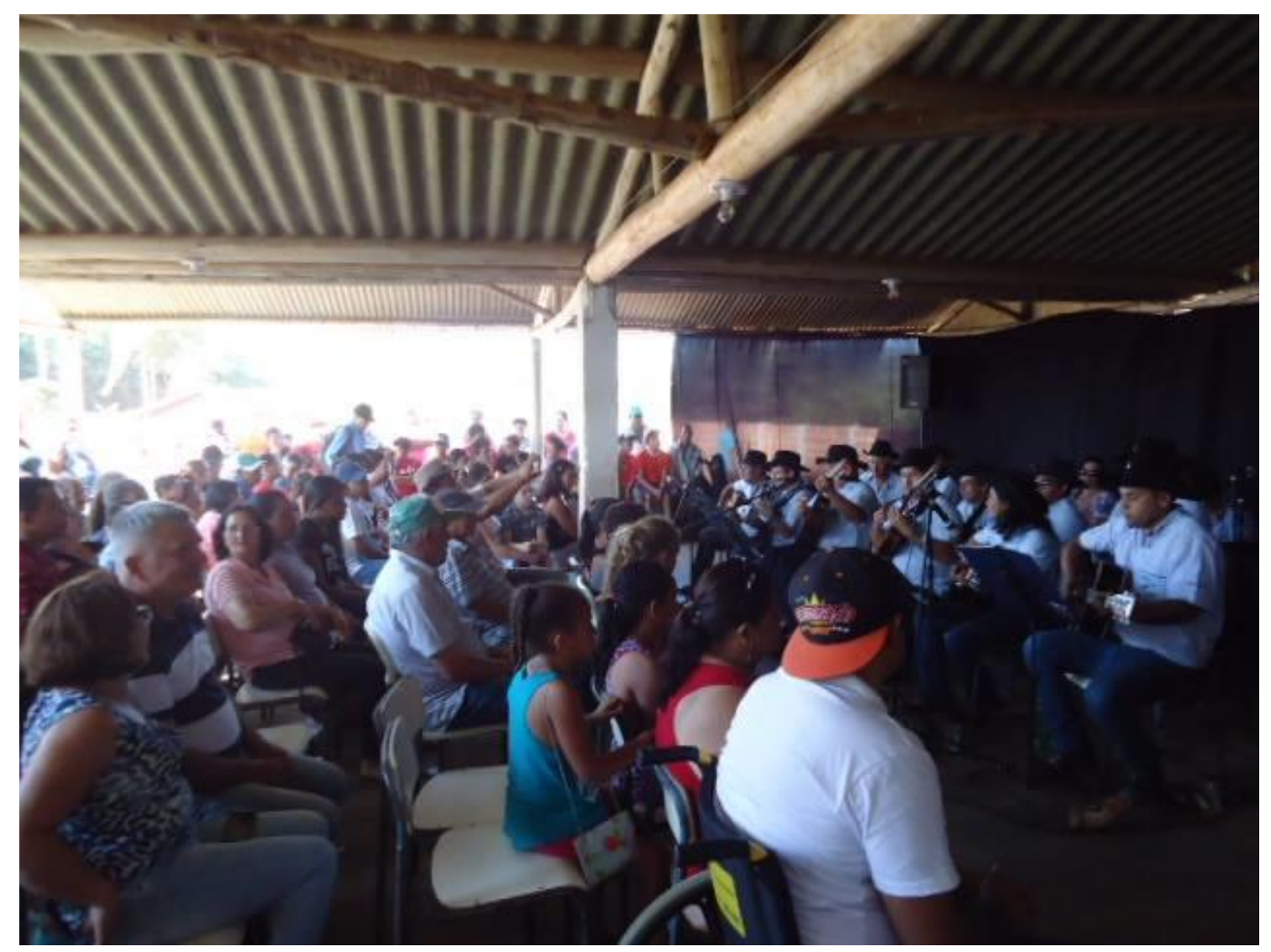

Foto 87: Público assistindo à orquestra de violeiros de Ribeirão Branco no projeto "Na Roça também se faz Cultura", bairro Capela de São Pedro, jun. 2015. Foto: Arquivo pessoal de João Luiz. 


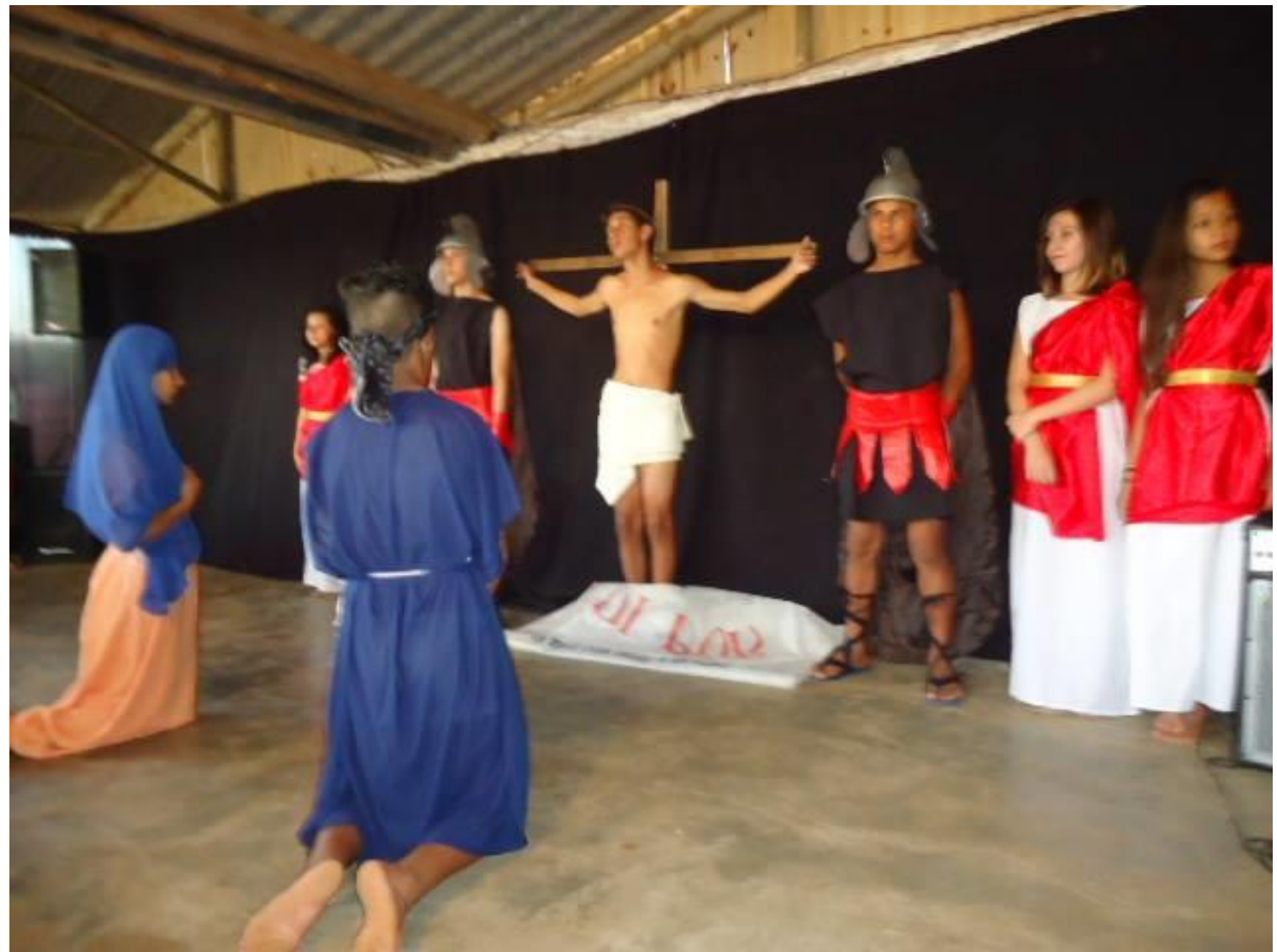

Foto 88: Apresentação de teatro no projeto "Na Roça também se faz Cultura", bairro Capela de São Pedro, jun. 2015. Foto: Arquivo pessoal de João Luiz.

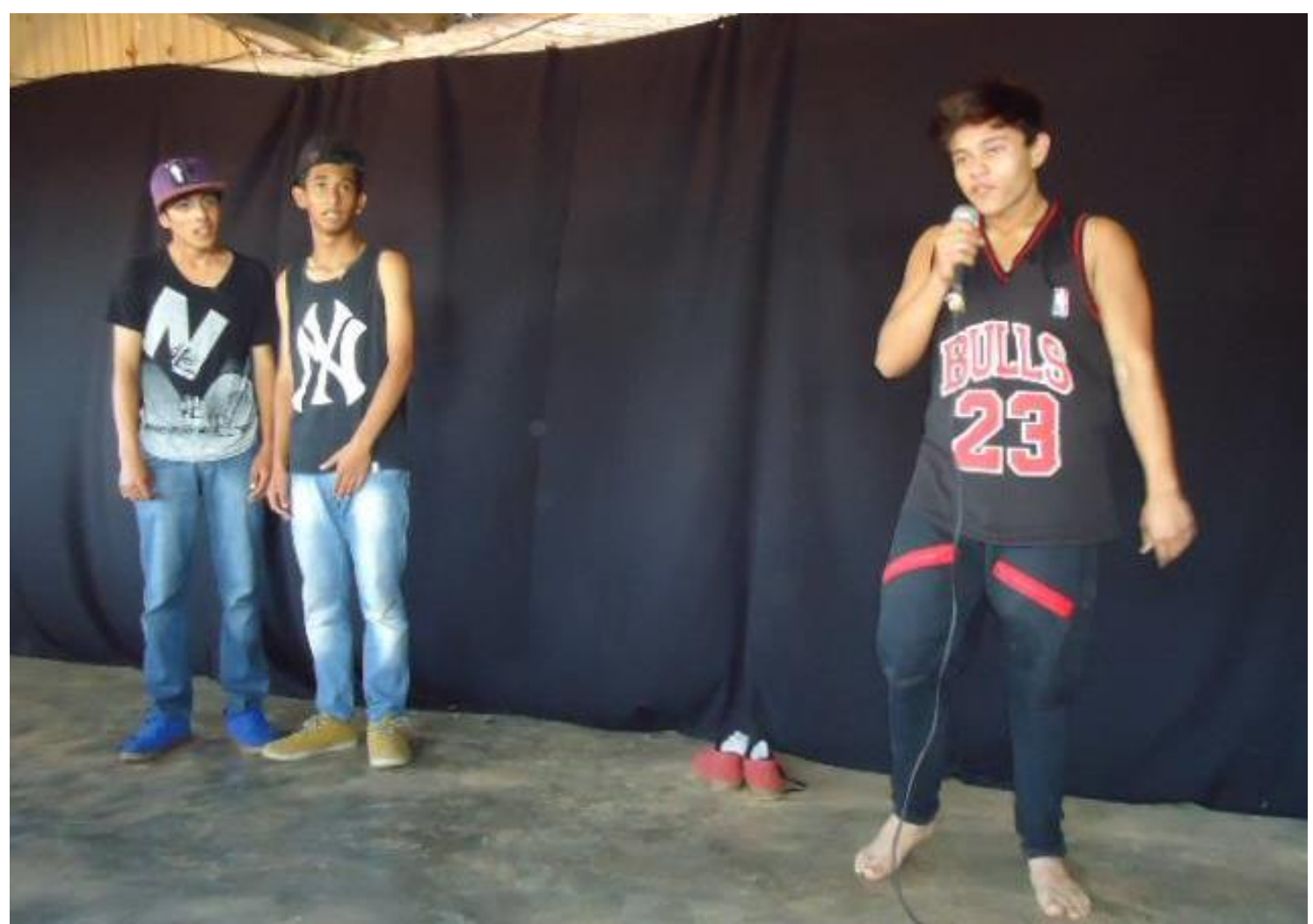

Foto 89: Apresentação de rap no projeto "Na Roça também se faz Cultura", bairro Capela de São Pedro, jun. 2015. Foto: Arquivo pessoal de João Luiz. 


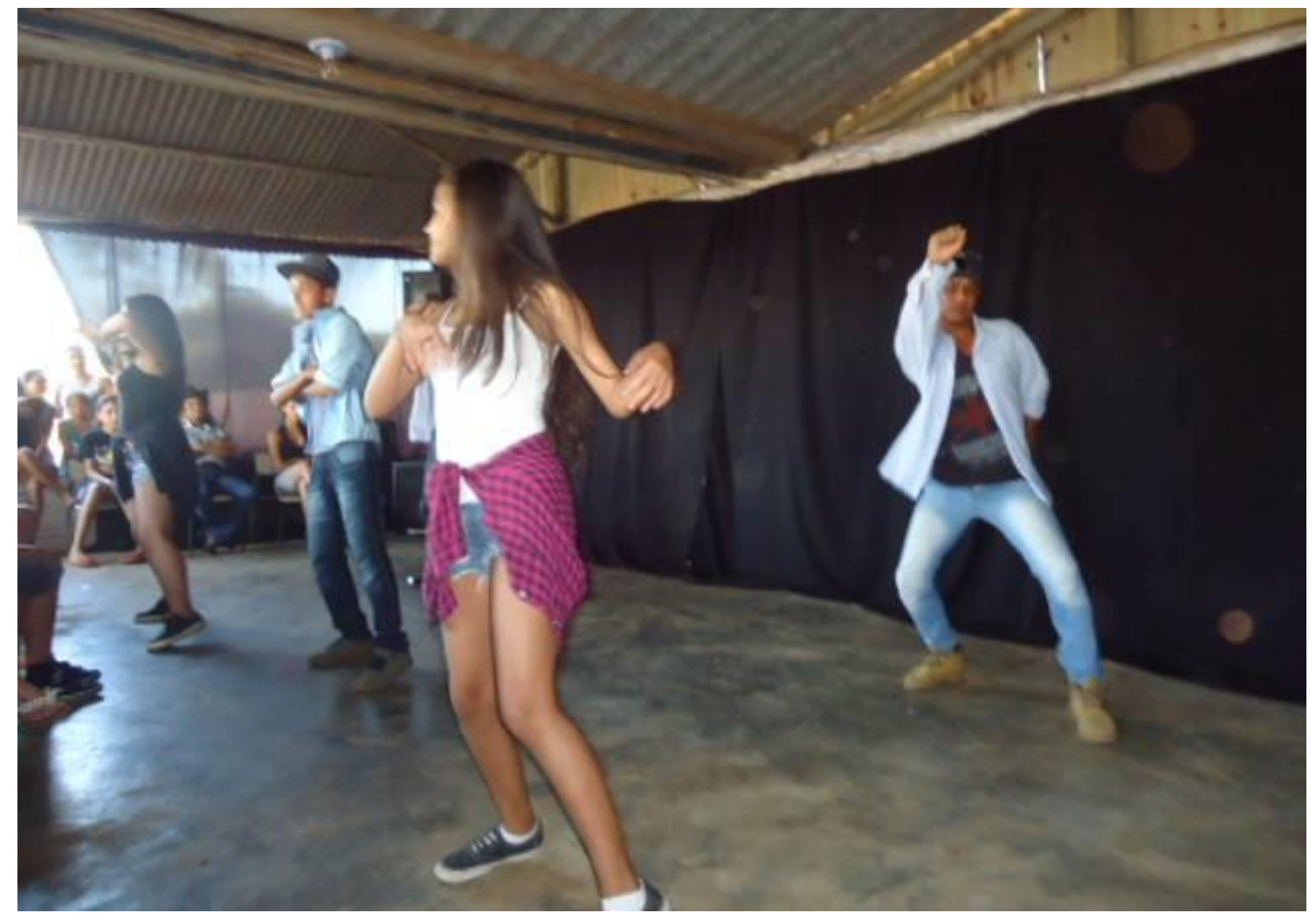

Foto 90: Apresentação de dança no projeto "Na Roça também se faz Cultura", bairro Capela de São Pedro, jun. 2015. Foto: Arquivo pessoal de João Luiz.

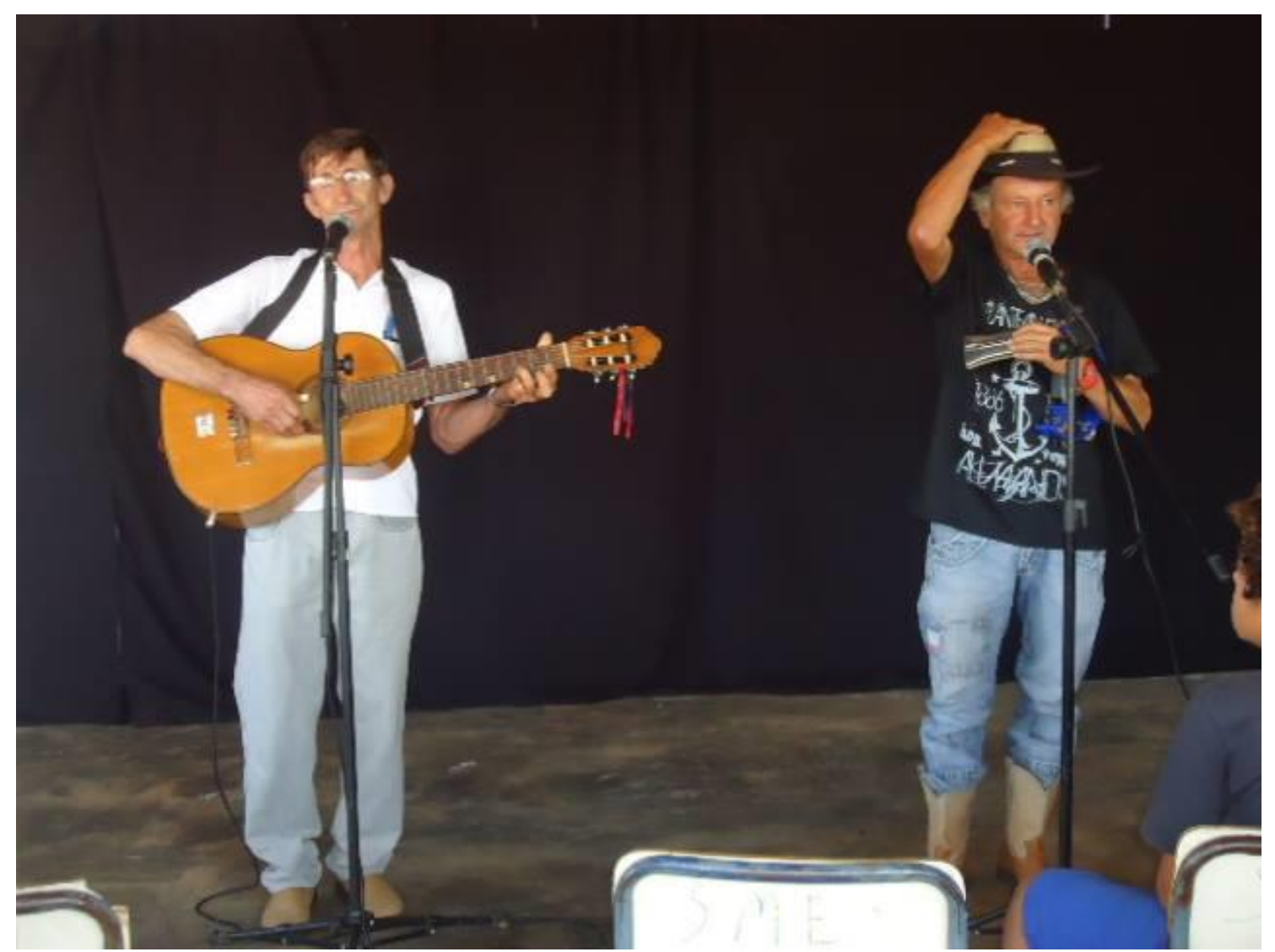

Foto 91: Apresentação musical no projeto "Na Roça também se faz Cultura", bairro Capela de São Pedro, jun. 2015. Foto: Arquivo pessoal de João Luiz. 


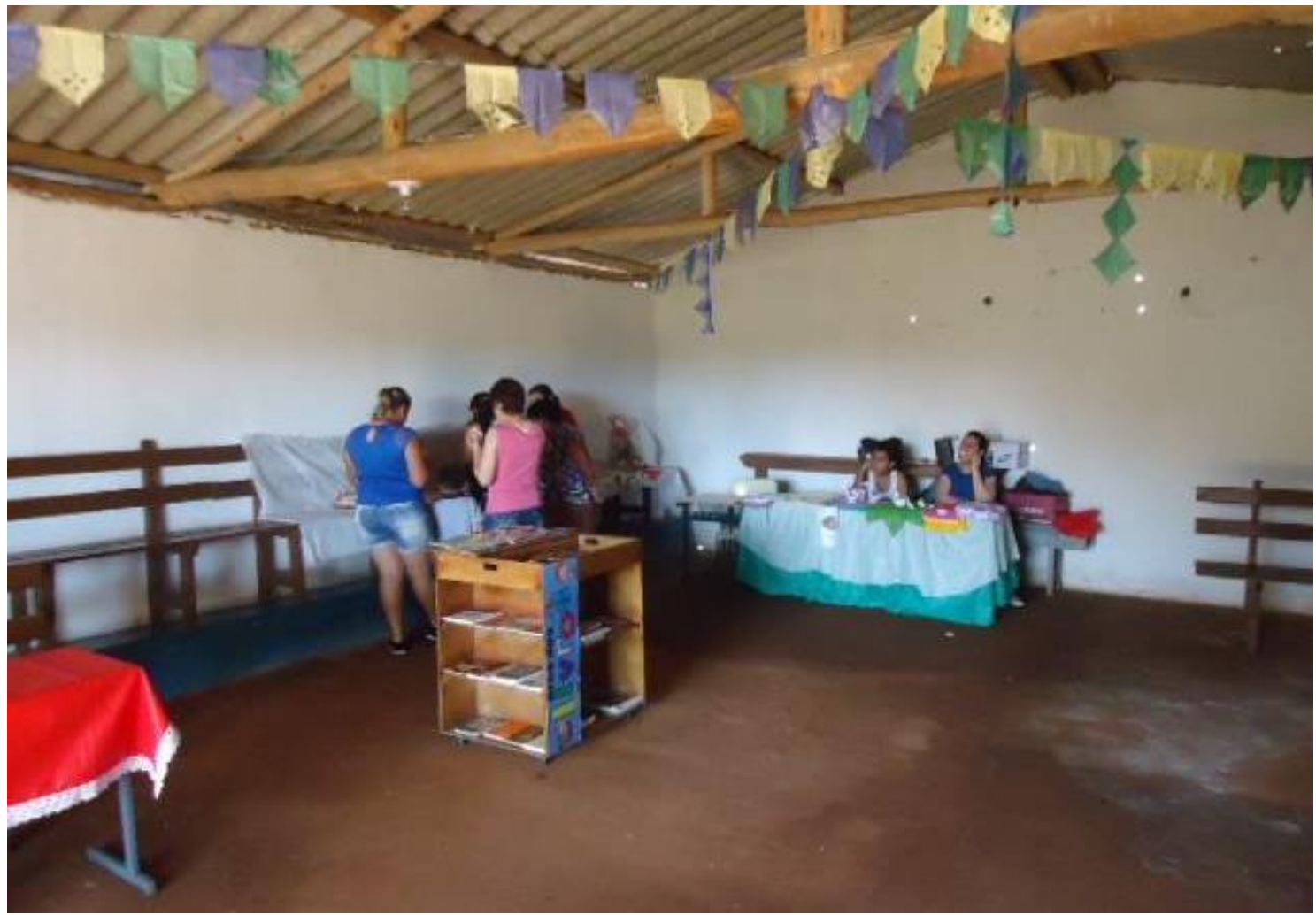

Foto 92: A biblioteca itinerante e o artesanato municipal são atrações do projeto "Na Roça também se faz Cultura", bairro Capela de São Pedro, jun. 2015.

Foto: Arquivo pessoal de João Luiz.

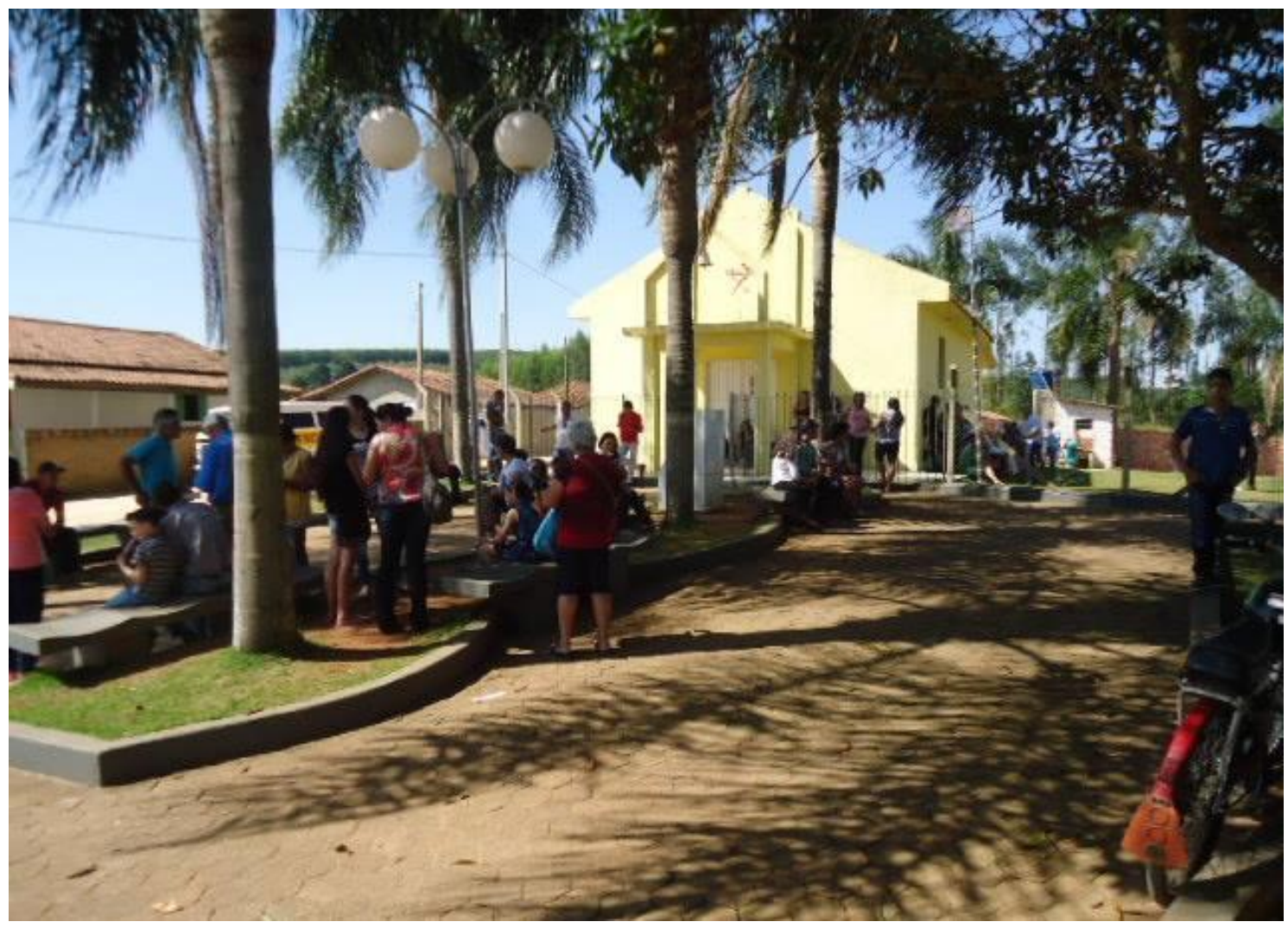

Foto 93: Centro do bairro Capela de São Pedro no dia da realização do projeto "Na Roça também se faz Cultura”, jun. 2015. Foto: Arquivo pessoal de João Luiz. 
Ao encerrarmos esse último capítulo, é importante afirmar que, ao apresentarmos a intensa vida cultural exercida pelos bairros rurais de Ribeirão Branco, podemos concluir que o campo não é, como muitos acreditam, um lugar onde não existem grandes alternativas culturais, de lazer e diversão. Além disso, ao explorar e apresentar as principais atividades realizadas pelos camponeses nesse município, buscamos evidenciar que a recriação camponesa transcende os aspectos meramente econômicos e se reflete na ativa vida religiosa e cultural desse modo de vida. 


\section{Considerações finais}

Estudar os camponeses é importante, não só porque os intelectuais podem produzir conhecimento voltado para os interesses dos camponeses, mobilizarse e lutar por eles, ou tentar fazer com que eles se mobilizem. Os camponeses podem nos ensinar uma variedade de coisas que nós não sabemos. A questão da flexibilidade de respostas em face dos desafios e crises econômicas é algo que o camponês pode ensinar àquele que não é camponês, muito mais do que o contrário, como se pode observar em inúmeras situações.

Eu acredito que podemos aprender com o campesinato e que ainda sabemos muito pouco a seu respeito. Nós temos poucas metodologias e metodologistas voltados a essa temática. (SHANIN, 2008, p. 28-29)

Essa citação ocupa um lugar especial neste trabalho porque trata da importância de se estudar o campesinato e aponta para o fato de conhecermos muito pouco sobre esses sujeitos. Além disso, afirma que temos muito mais o que aprender com eles do que a lhes ensinar.

Esta dissertação teve como objetivo analisar o modo de vida camponês e a sua diversidade e, em particular, os camponeses de Ribeirão Branco-SP. Apresentamos o campesinato enquanto um modo de vida plenamente ativo na sociedade contemporânea, descartando a hipótese de que esses sujeitos estariam em processo de desaparecimento.

Gostaríamos de enfatizar que, durante as nossas visitas às propriedades camponesas, uma de nossas preocupações era dar voz às mulheres e não ouvir somente os homens. Procuramos ouvi-las sempre que nos foi possível, buscando compreender o papel exercido por elas na família e na comunidade. Isso enriqueceu de maneira surpreendente as nossas análises.

Ao longo do trabalho, realizamos uma apresentação do nosso local de pesquisa demonstrando as características socioeconômicas, históricas e geográficas do município de Ribeirão Branco e dados estatísticos sobre a produção de tomates.

Discorremos sobre a produção capitalista de tomates em Ribeirão Branco, demonstrando o domínio da cadeia produtiva pelas empresas do ramo e as diferenças com a produção camponesa desse mesmo produto. Evidenciamos principalmente que, no caso da produção camponesa, existem outros aspectos determinantes para além do econômico e que esses elementos garantem a sua reprodução.

Vale destacar a riqueza dos depoimentos quando tratamos da diversificação da produção camponesa e do difícil trajeto dos camponeses para alcançarem a terra de trabalho - ouvimos histórias incríveis! Também apresentamos um conjunto de informações com entrevistas e material fotográfico em que mostramos as principais atividades culturais dos camponeses e a sua interação com a vida de bairro. 
Ao refletirmos sobre a teoria que aborda o conceito de campesinato, apresentamos o modo de vida das famílias camponesas em Ribeirão Branco, a sua produção, jornada de trabalho, dificuldades e desafios por eles apontados para a continuidade da propriedade familiar. Sobre isso, vale destacar o debate que fizemos sobre a socialização das crianças e sobre o jovem camponês.

Gostaríamos de registrar que, durante o trabalho de campo, ao ouvirmos os camponeses dizerem coisas como: "Ah... hoje vou à cidade"; "vou visitar fulano"; "vou ajudar nos preparativos da festa da igreja"; "vou ensaiar com o coral para cantar na missa"; "vou na cavalgada"; ou ainda, "ah, hoje vou pescar!", fomos confrontados por um sentimento de liberdade (de escolha) que é estranho ao mundo urbano.

Também é importante destacar que, como já vimos nas entrevistas, mesmo que nos últimos anos a produção de tomates tenha tido bons resultados tanto para os capitalistas quanto para os camponeses, conforme nos afirmou o próprio prefeito de Ribeirão Branco e pudemos observar nos últimos trabalhos de campo para a finalização desta pesquisa, a safra de 2016 não estava começando bem, diferentemente do que havia acontecido nos anos anteriores. Nos disseram que tanto a produção de tomate quanto as de repolho, pimentão, feijão vagem e frutas, como ameixa e pêssego, estavam sendo abandonadas no pé, sem nem mesmo serem colhidas, devido ao preço muito baixo que os poucos compradores estavam oferecendo. Ainda segundo esses camponeses, havia um excesso desses produtos no mercado e, por esse motivo, seria um ano muito difícil para o município.

Como vimos, a possibilidade de falência e de empobrecimento de camponeses e de capitalistas, principalmente daqueles que optaram por investir na monocultura do tomate, já apareciam nas nossas entrevistas. Para os camponeses, contudo, que culturalmente produzem uma grande variedade de produtos e que priorizam os alimentos para o consumo da família, os reflexos dos baixos preços dos produtos no mercado terão um impacto menor em momentos de crise.

Por fim, o objetivo principal de todo o percurso desta pesquisa nos parece provar que a classe camponesa não está se esgotando e não deixará de existir mesmo diante das crises dos baixos preços de seus produtos. O que procuramos elucidar foi uma realidade distante do discurso que defendem aqueles que seguem a teoria do desaparecimento desses sujeitos. Como afirmam Paulino e Almeida, o campesinato se adapta e se recria a seu modo:

A (re)criação do campesinato como uma relação não capitalista é parte contraditória do modo de produção capitalista, situação que, por sua vez, ao permitir a acumulação do capital via monopolização do território, também contém sua negação, seja na luta contra a transferência de renda, seja na luta 
direta pela terra de vida e trabalho. Cabe, portanto, na academia e fora dela entendê-los, dar-lhes visibilidade e, na luta, nos posicionar ao seu lado. (PAULINO; ALMEIDA, 2010, p. 58)

Encerramos essa dissertação com a esperança de que nossa tentativa de dar voz aos camponeses e estudá-los como detentores e sujeitos de direitos venha, mesmo que de forma modesta, somar à tese daqueles que acreditam no campesinato como um dos protagonistas nas lutas por uma sociedade mais solidária, justa e democrática. 


\section{Referências}

ALMEIDA, Rosemeire Aparecida de. (Re)criação do campesinato, identidade e distinção: a luta pela terra e o habitus de classe. São Paulo: Unesp, 2006.

ARCHETTI, P. Eduardo. “Contextualização histórica do debate sobre a questão agrária na Revolução Russa”. In: CARVALHO, Horácio Martins (org.). Chayanov e o campesinato. 1. ed., São Paulo: Expressão Popular, 2014. pp. 15-32.

AULICINO, Antônio Luís; PETRONI, Liége Mariel. "Processo prospectivo contribui para o desenvolvimento sustentável do município de Ribeirão Branco-São Paulo". In: SEMEAD, 15., out. 2012. Disponível em: <http://www.idsust.com.br/artigo/286.pdf>. Acesso em: 29 jun. 2016.

"Inovação: o processo de implantação do Parque Tecnológico para o Desenvolvimento Sustentável da região Sudoeste do estado de São Paulo: o caso do Município de Ribeirão Branco". In: SEMINÁRIO NACIONAL DE PARQUES TECNOLÓGICOS E INCUBADORAS DE EMPRESAS, 22., set. 2012, Foz do Iguaçu. Disponível em: <http://www.idsust.com.br/artigo/ID_306.pdf>. Acesso em: 29 jun. 2016.

AYROSA, Plínio. “Muchirão”. Revista do Arquivo Municipal, v. II, 1934.

BARTRA, Armando Vergés. Os novos camponeses: leituras a partir do México profundo. São Paulo: Cultura acadêmica; Cátedra Unesco de Educação do Campo e desenvolvimento Rural, 2011.

BENSAID, Daniel. Marx, manual de instruções. Ilustr.: Charb. Trad.: Nair Fonseca. 1. ed., São Paulo: Boitempo, 2013.

BOMBARDI, Larissa Mies. O bairro Reforma Agrária e o processo de territorialização camponesa. São Paulo: Annablume, 2004.

"O bairro rural como identidade territorial: e especificidade da abordagem do campesinato na geografia". Agrária, São Paulo, n. 1, jul.-dez. 2004. Disponível em: <http://www.geografia.fflch.usp.br/revistaagraria>. Acesso em: 20 jan. 2016.

BORGES, Cleiton Cunha. Produto 6: Estudo de caso acerca dos pareceres técnicos estaduais das regiões Centro-Oeste, Sudeste e Sul para a avaliação das unidades produtivas, avaliando os parâmetros nacionais e propondo aprimoramento dos parâmetros e dados utilizados para sua aprovação considerando os itens de sustentabilidade das propostas de financiamento do PNCF. Crédito Fundiário PCT/BRA/IICA/14/002 n. contrato: 114254. São Paulo, fev. 2016.

. Produto 5: Documento contendo avaliação das estratégias adotadas pelas entidades de ATER na elaboração dos Subprojetos de Investimentos Comunitários, com a proposição de metodologias para agilizar a análise e contratação dos projetos de SIC. Crédito Fundiário PTC/BRA/IICA/08/003 n.contrato:111.060. São Paulo, nov. 2011.

BRANDÃO, Carlos Rodrigues. A partilha da vida. São Paulo: Cabral, 1995.

BRASIL. Camponeses brasileiros: leituras e interpretações clássicas, v. 1. Org. Clifford 
Andrew Welch et al. São Paulo: Unesp; Brasília-DF: Núcleo de Estudos Agrários e Desenvolvimento Rural, 2009.

Diversidade do campesinato: expressões e categorias; v. 2: Estratégias de reprodução social. Org. Emilia Pietrafesa de Godoi, Marilda Aparecida de Menezes, Rosa Acevedo Marin. São Paulo: Unesp; Brasília-DF: Núcleo de Estudos Agrários e Desenvolvimento Rural, 2009.

Mulheres rurais e autonomia: formação e articulação para efetivar políticas públicas nos territórios da cidadania. Org. Andréa Butto, Nalu Faria, Karla Hora, Conceição Dantas, Miriam Nobre. Brasília-DF: Ministério do Desenvolvimento Agrário, 2014.

Ministério do Desenvolvimento Agrário. Secretaria de Desenvolvimento Territorial. Plano Safra Territorial - Região Sudeste: Médio Jequitinhonha, Médio Rio Doce, Serra do brigadeiro, Sudeste Paulista, Vale do Ribeira, Norte do Espírito Santo. São Paulo: Plural, dez. 2006.

CADERNO de Agroecologia. São Paulo: Expressão Popular, out. 2015.

CAMARGO. Lidiane; MUSSOI, Eros Marion; CAZELLA, Ademir Antonio. "Banco da Terra e Crédito Fundiário: entre o passado e o futuro". In: CONGRESSO DA SOBER, 43.: instituições, eficiência, gestão e contratos no sistema agroindustrial, 2005, Ribeirão Preto. Disponível em: <http://www.sober.org.br/palestra/2/555.pdf>. Acesso em: ago. 2016.

CANDIDO, A. Os parceiros do Rio Bonito: estudo sobre o caipira e a transformação dos seus meios de vida. Rio de Janeiro: Ouro Sobre Azul, 2010.

CARVAlHO, Horácio Martins (org.). Chayanov e o campesinato. 1. ed., São Paulo: Expressão Popular, 2014.

CARVALHO, Jefferson Luiz de; PAGLIUCA, Larissa Gui. "Tomate: um mercado que não para de crescer". Hortifruti Brasil, Piracicaba-SP: Cepea-Esalq, jun. 2007. Disponível em: <http://www.cepea.esalq.usp.br/hfbrasil/edicoes/58/mat_capa.pdf >. Acesso em: 8 fev. 2016.

CEPEA. "Tomate: de vilão a mocinho". Hortifruti Brasil, Piracicaba-SP: Cepea-Esalq, dez. 2013-jan. 2014. Disponível em: 〈http://cepea.esalq.usp.br/hfbrasil/edicoes/130/tomate.pdf〉. Acesso em: ago. 2016.

"Tomate: clima instável e custo em alta devem limitar investimentos para 2016". Hortifruti Brasil, Piracicaba-SP: Cepea-Esalq, dez. 2015-jan. 2016. Disponível em: <http://cepea.esalq.usp.br/hfbrasil/edicoes/152/tomate.pdf>. Acesso em: ago. 2016.

CHAYANOV, A. V. The theory of peasant economy. Illinois: Kerblay y Smith, 1966.

"Teoria dos sistemas econômicos não capitalistas" (1924). Trad. Manuel Villaverde Cabral. In: CARVALHO, Horácio Martins (org.). Chayanov e o campesinato. São Paulo: Expressão Popular, 2014. 1974.

. La Organización de la Unidad Económica Campesina. Buenos Aires: Nueva Visión,

CUT. Desenvolvimento sustentável: o que nós, classe trabalhadora, temos a ver com isso? São Paulo: Garilli, 2014. 
2015.

Agrotóxicos: impactos na vida e no trabalho - um risco que você não vê. São Paulo,

DIEESE. Escritório Regional de Goiás. A produção mundial e brasileira de tomate. 2010. Disponível em: <https://www.dieese.org.br/projetos/informalidade/estudoSobreAproducaoDeTomateIndustria 1NoBrasil.pdf $>$. Acesso em: 8 fev. 2016.

ENGELS, Friedrich. "O problema camponês na França e na Alemanha”. In: GRAZIANO DA SILVA, José; STOLCKE, Verena (org.). A questão agrária. São Paulo: Brasiliense, 1981. pp. 59-80.

s/d.

. A origem da família, da propriedade privada e do Estado. 2. ed., São Paulo: Escala,

FABRINI, João Edmilson; ROOS, Djorni. Conflitos territoriais entre campesinato e o agronegócio latifundiário. São Paulo: Outras expressões, 2014.

FERNANDES, Bernardo Mançano; WELCH, Clifford Andrew; GONÇALVES, Elienai Constantino. Os usos da terra no Brasil: debates sobre políticas fundiárias. 1. ed., São Paulo: Cultura Acadêmica; Unesco, 2014.

FRANÇA, Caio Galvão de; GROSSI, Mauro Eduardo Del; MARQUES, Vicente P. M. de Azevedo. $\mathrm{O}$ censo agropecuário 2006 e a agricultura familiar no Brasil. Brasília: MDA, $2009 . \quad$ Disponível em: <http://www.bb.com.br/docs/pub/siteEsp/agro/dwn/CensoAgropecuario.pdf>. Acesso em: ago. 2016.

GERARDI, Lúcia H.O.; SALAMONI, Giancarla. "Para entender o campesinato: a contribuição de A.V. Chayanov". In: CARVALHO, Horácio Martins (org.). Chayanov e o campesinato. São Paulo: Expressão Popular, 2014. pp. 163-178.

GUZMÁn, Eduardo S.; MOLINA, Manuel G. de. Sobre a evolução do conceito de campesinato. 2. ed., São Paulo: Expressão Popular, 2013.

HOBSBAWM, E.J.; RUDÉ, George. Capitão Swing. Trad. Marco Antonio Pamplona e Maria Luiza da Silva Pinto. Rio de Janeiro: Francisco Alves, 1982.

HOBSBAWM, E.J. Rebeldes e primitivos: estudos sobre formas arcaicas de movimentos sociais nos séculos XIX e XX. Rio de Janeiro: Zahar, 1970.

Bandidos. 4. ed., São Paulo: Paz e Terra, 2010.

IBGE. Sinopse do censo demográfico 2010. Brasília, 2010. Disponível em: <http://www.censo2010.ibge.gov.br/sinopse/index.php?dados=27\&uf=35>. Acesso em: 6 abr. 2016.

IBGE Cidades: Ribeirão Branco - SP. Brasília, 2015. Disponível em: <http://cidades.ibge.gov.br/xtras/perfil.php?lang=\&codmun=354300\&search=||infogr\%E1fico s:-informa\%E7\%F5es-completas $>$. Acesso em: ago. 2016. 
"Tabela 1618 - Área plantada, área colhida e produção, por ano da safra e produto". Levantamento sistemático da produção agrícola. Brasília, 2016. Disponível em: <https://sidra.ibge.gov.br/tabela/1618\#/n1/all/n3/all/v/35,109/p/all/c49/allxt/c48/39470/l/t,v+c 49,p+c48/resultado>. Acesso em: jan. 2017.

INSTITUTO KAIRÓS, 2012. Disponível em: 〈www.institutokairos.net>. Acesso em: 10 jul. 2014.

IOKOI, Zilda Márcia Grícoli. Igreja e camponeses: teologia da libertação e movimentos sociais no campo Brasil e Peru, 1964-1986. São Paulo: Hucitec, 1996.

ITESP. Cadernos Itesp 4: Terra e cidadãos: aspectos da ação de regularização fundiária no estado de São Paulo. 2. ed., São Paulo, 2000. Disponível em: <http://www.itesp.sp.gov.br/br/info/publicacoes/arquivos/terra_cidadaos_2e.pdf >. Acesso em: 9 set. 2014.

<http://201 Plano Nacional de Crédito Fundiário. Disponível em:

LIMA, Lucinei Paes de. "Características do campesinato: teorias e abordagens". In: SIMPÓSIO INTERNACIONAL DE GEOGRAFIA AGRÁRIA, 7.; SIMPÓSIO NACIONAL DE GEOGRAFIA AGRÁRIA, 8., 2015, Goiânia. Anais... Goiânia, 2015.

LOWY, Michael. As aventuras de Karl Marx contra o Barão de Munchhausen: marxismo e positivismo na sociologia do conhecimento. 10. ed., São Paulo: Cortez, 2013.

MARCOS, V. Alternative per la produzione agrícola contadina nell'ottica dello sviluppo locale autosostenibile. Genova, 2004. Tese (Doutorado) - Universitá degli Studi di Genova, Italia.

"Novas utopias, velhos horizontes: reflexões atuais sobre a teoria e a prática do desenvolvimento local auto-sustentável". In: PREVE, Ana Maria; CORRÊA, Guilherme (orgs.). Ambientes da ecologia: perspectivas em política e educação. Santa Maria: UFSM, 2007.

MARIANO, Neusa de Fátima. Divina tradição ilumina Mogi das Cruzes: o Espírito Santo faz a festa. São Paulo, 2007. Tese (Doutorado em Geografia Humana) - Faculdade de Filosofia, Letras e Ciências Humanas, Universidade de São Paulo.

MARQUES, M. I. M. "A atualidade do uso do conceito de camponês". Revista Nera, Presidente Prudente-SP: Unesp, ano 11, n. 12, jan.-jun. 2008.

MARTINELLO, S. André; SCHNEIDER, Sérgio. "Paralelo entre Antonio Candido e Alexandre Chayanov: economia fechada, equilíbrio mínimo e rusticidade”. In: CARVALHO, Horácio Martins (org.). Chayanov e o campesinato. São Paulo: Expressão Popular, 2014. pp. 273-298.

MARTINEZ-ALIER, Joan. O ecologismo dos pobres. São Paulo: Contexto, 2007.

MARTINS, José de Souza. Os camponeses e a política no Brasil. Petrópolis: Vozes, 1981.

Os camponeses e a política no Brasil. Petrópolis: Vozes, 1990. 
O cativeiro da terra. 9. ed. rev. e ampl., São Paulo: Contexto, 2010.

Sociedade vista do abismo: novos estudos sobre exclusão, pobreza e classes sociais. Petrópolis: Vozes, 2003.

MARX, Karl. O 18 de Brumário de Luís Bonaparte. São Paulo: Boitempo, 2011.

Manuscritos econômicos-filosóficos e outros textos escolhidos. Seleção de textos de José Arthur Giannotti. 3. ed., São Paulo: Abril Cultural, 1985.

O capital: crítica da economia política - o processo global da produção capitalista, livro 3, vol. IV. Rio de Janeiro: Civilização Brasileira, s.d.

O capital, t. III. Buenos Aires, 1956.

MOURA, Margarida. M. Os herdeiros da terra. São Paulo: Hucitec, 1978.

Camponeses. São Paulo: Ática, 1986.

MST. Pequenas propriedades têm 95,9\% de produção ativa contra $3 \%$ das grandes. Disponível em: <http://www.jornadaagroecologia.com.br/?p=1781>. Acesso em: ago. 2016.

NETO, Waldemiro Alcântara da Silva. "Relação de longo prazo entre os preços do tomate nos estados de São Paulo e Goiás”. Revista Informações Econômicas, São Paulo, v. 44, n. 2, mar.abr., 2014.

NETTO, José Paulo (org.). A criação destruidora: curso livre Marx-Engels. São Paulo: Boitempo, 2015.

OLIVEIRA, A. U. "Agricultura e indústria no Brasil”. Boletim Paulista de Geografia, São Paulo, n. 58, 1981.

Modo de produção capitalista, agricultura. São Paulo: Ática, 1986.

A agricultura camponesa no Brasil. São Paulo: Contexto, 1991.

"Agricultura Brasileira Transformações Recentes". In: ROSS, Jurandyr Luciano Sanches (org.). Geografia do Brasil. São Paulo: Edusp, 1998.

. "A longa marcha do campesinato brasileiro: movimentos sociais, conflitos e reforma agrária”. Estudos Avançados, São Paulo, v. 15, n. 43, 2001. pp. 185-206.

2007.

Modo de produção capitalista, agricultura e reforma agrária. São Paulo, FFLCH,

PAULILO, Maria Ignez S. "Movimentos das mulheres agricultoras e os muitos sentidos da 'igualdade de gênero"'. In: FERNANDES, Bernardo Mançano; MEDEIROS, Leonilde Servolo de; PAULILO, Maria Ignez (orgs.). Lutas camponesas contemporâneas: condições, dilemas e conquistas, v. 2. São Paulo: Unesp; Brasília, DF: Núcleo de Estudos Agrários e Desenvolvimento Rural, 2009.

PAULINO, Eliane T.; FABRINI, João E. (orgs.). Campesinato e territórios em disputa. São Paulo: Expressão Popular, 2008. 
PAULINO, Eliane Tomiasi; ALMEIDA, Rosimeire Aparecida. Terra e território: a questão camponesa no capitalismo. 1. ed., São Paulo: Expressão Popular, 2010.

PAULINO, Eliane Tomiasi. Por uma geografia dos camponeses. 2. ed., São Paulo: Unesp, 2012.

PNUD; IPEA; Fundação João Pinheiro. Atlas do desenvolvimento humano no Brasil: Ribeirão Branco, [s.d.]. Disponível em: <http://www.atlasbrasil.org.br/2013/pt/perfil_m/ribeirao-branco_sp>. Acesso em: 15 ago. 2016.

QUEIROZ, Maria Isaura Pereira de. Bairros rurais paulistas: dinâmica das relações bairro rural - cidade. São Paulo: Duas Cidades, 1973a.

O campesinato brasileiro. Rio de Janeiro: Vozes, 1973b.

RIBEIRO, Marlene. Movimento camponês: trabalho e educação; liberdade, autonomia, emancipação: princípios/fins da formação humana. São Paulo: Expressão Popular, 2013.

SACHS, Ignacy. Rumo à ecossocioeconomia. São Paulo: Cortez, 2007.

SANTOS, Boaventura. Pela mão de Alice: o social e o político na pós- modernidade. São Paulo: Cortez, 1995.

SANTOS, J. V. Tavares dos. Colonos do vinho. São Paulo: Hucitec, 1978.

SÃO PAULO. Governo do Estado. Secretaria de Agricultura e Abastecimento. Coordenadoria de Assistência Técnica Integral. Instituto de Economia Agrícola. "Distribuição geográfica da área cultivada e número de produtores, 2007/2008". Levantamento censitário de unidades de produção agrícola do estado de São Paulo - LUPA 2007/2008. [São Paulo, s.d.a]. Disponível em: <http://www.cati.sp.gov.br/projetolupa/mapaculturas/Tomateenvarado.php>. Acesso em: ago. 2016.

Tabelas 476.1 a 476.5. Levantamento censitário de unidades de produção agrícola do estado de São Paulo - LUPA 2007/2008. [São Paulo, s.d.b]. Disponível em: <http://www.cati.sp.gov.br/projetolupa/dadosmunicipais/pdf/t476.pdf>. Acesso em: ago. 2016.

Estatísticas da produção paulista. [São Paulo, s.d.c]. Disponível em: <http://ciagri.iea.sp.gov.br/nia1/subjetiva.aspx?cod_sis=1\&idioma=1>. Acesso em: jan. 2017.

SÃO PAULO. Governo do Estado. Secretaria de Cultura. A Dança de São Gonçalo - Ribeirão Branco. Direção de Cleiner Micceno. Mambo Produções, 2013 (9,5 minutos). Disponível em: <https://www.youtube.com/watch?v=Krv7Yny7J2s>. Acesso em: 29 jan. 2016.

SCHWENDLER, Sônia Fátima. "A participação da mulher na luta pela terra: dilemas e conquistas”. In: FERNANDES, Bernardo Mançano; MEDEIROS, Leonilde Servolo de; PAULILO, Maria Ignez (orgs.). Lutas camponesas contemporâneas: condições, dilemas e conquistas, v. 2. São Paulo: Unesp; Brasília, DF: Núcleo de Estudos Agrários e Desenvolvimento Rural, 2009. pp. 203-221.

SHANIN, Teodor. Naturaleza y lógica de la economía campesina. Madrid: Anagrama, 1976. 
La Clase Incomoda. Madrid: Alianza Editorial, 1983.

. "A definição de camponês: conceituações e desconceituação - o velho e o novo em uma discussão marxista”. Estudos Cebrap, n. 26, 1980.

"Lições camponesas". In: PAULINO, Eliane T.; FABRINI, João E. (orgs.).

Campesinato e territórios em disputa. São Paulo: Expressão Popular, 2008. pp. 23-47.

SILVA, Rafaela Cristina da; MARTINI, Rodrigo. "Tomate mergulha na tecnologia". Hortifruti Brasil, Piracicaba-SP: Cepea-Esalq, jun. 2006. Disponível em: <http://cepea.esalq.usp.br/hfbrasil/edicoes/47/mat_capa.pdf>. Acesso em: ago. 2016.

SPOSITO, Maria Encarnação Beltrão; WHITACKER, Arthur Magon (orgs.). Cidade e campo: relações e contradições entre urbano e rural. 2. ed., São Paulo: Expressão Popular, 2010.

STÉDILE. João Pedro (org.). História e natureza das Ligas Camponesas - 1954-1964. 2. ed., São Paulo: Expressão Popular, 2012.

VILELA, Nirlene Junqueira. "Situação da produção de tomate no Brasil". Embrapa Hortaliças, 2009. Disponível em: <http://documents.tips/documents/situacao-da-producao-detomate-no-brasil.html>. Acesso em: ago. 2016.

VIVALDO, Fernando Vicente. Educação em direitos humanos e teoria crítica: por um projeto emancipatório. São Paulo, 2014. Tese (Doutorado em Educação) - Faculdade de Educação, Universidade de São Paulo.

WOORTMANN, Ellen. F. “O saber camponês: práticas ecológicas tradicionais e inovações”. In: GODOI, Emília Pietrafesa de; MENEZES, Marilda Aparecida de; MARIN, Rosa Acevedo (orgs.). Diversidade do campesinato: expressões e categorias, v. 2: Estratégias de reprodução social. São Paulo: Unesp; Brasília-DF: Núcleo de Estudos agrários e Desenvolvimento Rural, 2009. pp. 119-129.

WOORTMANN, K. "Com parente não se neguceia: o campesinato como ordem moral". Anuário Antropológico, Rio de Janeiro: Tempo Brasileiro, n. 87, 1990. 
Anexo

O Levantamento censitário das unidades de produção agropecuária do estado de São Paulo (LUPA) nos revelam detalhes sobre outras produções e a infraestrutura do município de Ribeirão Branco (SÃO PAULO, s.d.b).

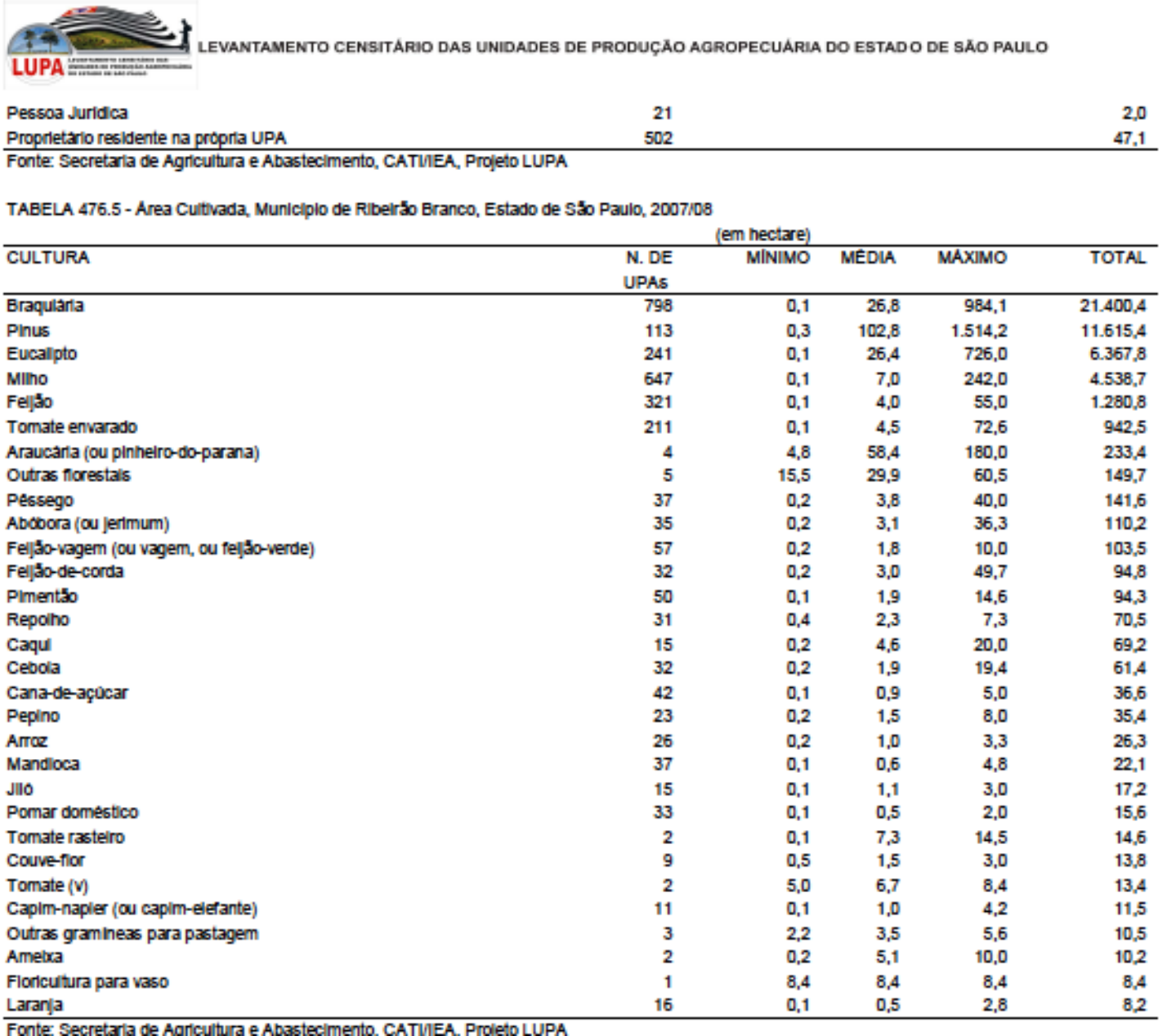

Fonte: Secretaria de Aoricultura e Abastecimento. CATUIEA. Proleto LUPA 
HPA LEVANTAMENTO CENSITÁRIO DAS UNIDADES DE PRODUÇÃO AGROPECUARIA DO ESTADO DE SÃO PAULO

TABELA 476.1 - Estatisticas Agricolas, Municiplo de Ribeiräo Branco, Estado de Säo Paulo, 2007/08

\begin{tabular}{|c|c|c|c|c|c|c|}
\hline ITEM & UNIDADE & $\begin{array}{l}\text { N.DE } \\
\text { UPAs }\end{array}$ & MINIMO & MÉDIA & MAXIMO & TOTAL \\
\hline Dlstancla a sede do municiplo & $\mathrm{km}$ & 1.065 & 0,1 & 13,9 & 37,0 & - \\
\hline Area total & hectare & 1.065 & 0,1 & 69,2 & $2.441,8$ & 73.687 .4 \\
\hline Area com cultura perene & hectare & 104 & 0,1 & 2,6 & 40,0 & 273,2 \\
\hline Area com cutura temporarla & hectare & 759 & 0,1 & 8,9 & 181,5 & $6.789,0$ \\
\hline Area com pastagens & hectare & 801 & 0,1 & 26,7 & 984,1 & $21.425,4$ \\
\hline Area com reflorestamento & hectare & 325 & 0,1 & 56,5 & $1.514,2$ & $18.366,3$ \\
\hline Area com vegetaç5̆o natural & hectare & 875 & 0,1 & 26,4 & $1.633,5$ & 23.077,1 \\
\hline Area com vegetaçăo de brejo e varzea & hectare & 52 & 0,1 & 1,3 & 19,9 & 69,2 \\
\hline Area em descanso & hectare & 363 & 0,1 & 4,5 & 130,7 & $1.650,5$ \\
\hline Area complementar & hectare & 999 & 0,1 & 2,0 & 490,0 & $2.036,6$ \\
\hline Area das UPAs com $(0,1]$ ha & hectare & 19 & 0,1 & 0,6 & 1,0 & 12,0 \\
\hline Area das UPAs com $(1,2]$ ha & hectare & 23 & 1,1 & 1,4 & 2,0 & 31,4 \\
\hline Area das UPAs com $(2,5]$ ha & hectare & 124 & 2,2 & 3,6 & 5,0 & 446,9 \\
\hline Area das UPAs com $(5,10]$ ha & hectare & 165 & 5,1 & 7,9 & 10,0 & $1.309,8$ \\
\hline Area das UPAs com $(10,20]$ ha & hectare & 213 & 10,4 & 14,8 & 19,4 & $3.147,6$ \\
\hline Area das UPAs com $(20,50]$ ha & nectare & 254 & 20,4 & 31,8 & 48,5 & $8.075,7$ \\
\hline Area das UPAs com $(50,100)$ ha & hectare & 112 & 50,4 & 71,3 & 99,2 & $7.991,1$ \\
\hline Area das UPAs com $(100,200]$ ha & hectare & 75 & 101,6 & 144,1 & 193,6 & $10.804,9$ \\
\hline Area das UPAs com $(200,500]$ ha & nectare & 60 & 202,0 & 312,4 & 498,1 & $18.746,7$ \\
\hline Area das UPAs com $(500,1.000]$ ha & hectare & 12 & 563,8 & 748,5 & 943,8 & $8.982,0$ \\
\hline Area das UPAs com $(1.000,2.000)$ ha & hectare & 7 & $1.210,0$ & $1.671,1$ & $1.965,0$ & $11.697,4$ \\
\hline Area das UPAs com $(2.000,5.000)$ ha & hectare & 1 & $2.441,8$ & $2.441,8$ & $2.441,8$ & $2.441,8$ \\
\hline Area das UPAs com $(5.000,10.000)$ ha & hectare & - & - & - & - & - \\
\hline Area das UPAs acima de $10.000 \mathrm{ha}$ & hectare & - & - & - & - & - \\
\hline Famillares do proprietario que trabalnam na UPA & unidade & 836 & 1,0 & 2,4 & 14,0 & $1.994,0$ \\
\hline Trabalhadores permanentes & unildade & 270 & 1,0 & 2,7 & 60,0 & 719,0 \\
\hline
\end{tabular}

Fonte: Secretarla de Agricultura e Abastecimento, CATUIEA, Projeto LUPA

TABELA 476.2 - Exploraçbes Animals, Municiplo de Ribeiråo Branco, Estado de Sła Paulo, 2007/08

\begin{tabular}{|c|c|c|c|c|c|c|}
\hline ITEM & UNIDADE & $\begin{array}{l}\text { N.DE } \\
\text { UPAS }\end{array}$ & MINIMO & MÉDIA & MAXIMO & TOTAL \\
\hline Bovinocultura de corte & cabeças & 38 & 5,0 & 115,4 & 800,0 & $4.386,0$ \\
\hline Bovinocultura de lelte & cabeças & 86 & 1,0 & 26,6 & $1.000,0$ & $2.287,0$ \\
\hline Bovinocultura mista & cabeças & 463 & 1,0 & 27,7 & 400,0 & $12.847,0$ \\
\hline Buballnocultura & cabeças & 6 & 22,0 & 38,3 & 60,0 & 230,0 \\
\hline Aplcultura & coimelas & 6 & 2,0 & 16,8 & 40,0 & 101,0 \\
\hline Asininos e muares & cabeças & 218 & 1,0 & 2,6 & 15,0 & 573,0 \\
\hline Avestruz e ema & cabeças & - & - & - & - & - \\
\hline Avicultura de corte & cab.jano & 6 & 20,0 & 536,7 & $3.000,0$ & $3.220,0$ \\
\hline Avcultura ornamentaldecorativalewotica & cabeças & 223 & 2,0 & 31,8 & 250,0 & $7.090,0$ \\
\hline Avicultura para ovos & cabeças & 342 & 1,0 & 40,5 & 500,0 & $13.863,0$ \\
\hline Caplvaras & cabeças & - & - & - & - & - \\
\hline Caprinocultura & cabeças & 45 & 1,0 & 12,4 & 120,0 & 559,0 \\
\hline Carcinocultura & pos-larvas & 2 & 10,0 & 14,0 & 18,0 & 28,0 \\
\hline Codomicultura & cabeças & 2 & 4,0 & 52,0 & 100,0 & 104,0 \\
\hline Cunicultura & cabeças & 2 & 10,0 & 15,0 & 20,0 & 30,0 \\
\hline Equinocultura & cabeças & 451 & 1,0 & 3,3 & 30,0 & $1.468,0$ \\
\hline Hellcicultura & vivelros & - & - & - & - & - \\
\hline Jacares & cabeças & - & - & - & - & - \\
\hline Javals & cabeças & - & - & - & - & - \\
\hline Minhocultura & cantelros & - & - & - & - & - \\
\hline Mitllicultura & vivelros & - & - & - & - & - \\
\hline Ovinocultura & cabeças & 23 & 2,0 & 22,9 & 150,0 & 527,0 \\
\hline Plscicutura, area de tanques & $\mathrm{m} 2$ & 1 & 40,0 & 40,0 & 40,0 & 40,0 \\
\hline Ranicutura & girinos/ano & - & - & - & - & - \\
\hline Sericicultura (larvas) & gramas/ano & - & - & - & - & - \\
\hline Sulnocultura & cabeças & 290 & 1,0 & 12,9 & 300,0 & $3.728,0$ \\
\hline Outra exploraç̧o animal & cabecas & 26 & 3,0 & 40,8 & 120,0 & $1.061,0$ \\
\hline
\end{tabular}

Fonte: Secretaria de Aaricultura e Abastecimento. CATVIEA. Proleto LUPA 
TABELA 476.3 - Maquinas, Implementos e Benfeltorias, Municiplo de Ribelrăo Branco, Estado de Sło Paulo, 2007/08

\begin{tabular}{|c|c|c|c|c|c|c|}
\hline ITEM & UNIDADE & $\begin{array}{l}\text { N. DE } \\
\text { UPAS }\end{array}$ & MINIMO & MÉDIA & MAXIMO & TOTAL \\
\hline Arado comum (Bacla, Alveca) & unidade & 97 & 1,0 & 1,1 & 3,0 & 109,0 \\
\hline Arado escantifcador & unidade & 19 & 1,0 & 1,3 & 5,0 & 25,0 \\
\hline Arado subsolador & unidade & 10 & 1,0 & 1,0 & 1,0 & 10,0 \\
\hline Batedelra de cereals & unidade & 118 & 1,0 & 1,1 & 3,0 & 132,0 \\
\hline Camara fria & unidade & - & - & - & - & - \\
\hline Carregadelra de cana & unidade & 11 & 1,0 & 1,3 & 3,0 & 14,0 \\
\hline Colhedeira acoplada & unidade & 1 & 1,0 & 1,0 & 1,0 & 1,0 \\
\hline Colhedelra automotriz & unidade & 1 & 1,0 & 1,0 & 1,0 & 1,0 \\
\hline Computador & unidade & 2 & 1,0 & 1,0 & 1,0 & 2,0 \\
\hline Conjunto de imigaçăo autopropelldo & unidade & 1 & 1,0 & 1,0 & 1,0 & 1,0 \\
\hline Conjunto de imigaçăo convencional & unidade & 233 & 1,0 & 1,4 & 6,0 & 315,0 \\
\hline Conjunto de irmigaçăo plvot central & unidade & - & - & - & - & - \\
\hline Conjunto de imigaç̧o gotejamento/microaspersశోo & unidade & 5 & 1,0 & 1,6 & 3,0 & 8,0 \\
\hline Conjunto de fenaç5o & unidade & 2 & 1,0 & 1,0 & 1,0 & 2,0 \\
\hline Desintegrador de palha (Plantio direto) & unidade & 9 & 1,0 & 1,0 & 1,0 & 9,0 \\
\hline Desintegrador, picador, triturador & unidade & 118 & 1,0 & 1,1 & 3,0 & 128,0 \\
\hline Distribuldor de calcario & unidade & 8 & 1,0 & 1,0 & 1,0 & 8,0 \\
\hline Ensiladelra & unidade & 9 & 1,0 & 1,0 & 1,0 & 9,0 \\
\hline Grade aradora (tipo roml) & unidade & 38 & 1,0 & 1,1 & 3,0 & 40,0 \\
\hline Grade niveladora & unidade & 77 & 1,0 & 1,1 & 2,0 & 85,0 \\
\hline Implementos para traçăo animal & unidade & 34 & 1,0 & 3,0 & 8,0 & 101,0 \\
\hline Maquina de classinicar fruta & unidade & - & - & - & - & - \\
\hline Maquina de classificar olericola & unidade & - & - & - & - & - \\
\hline Maquina de classilicar ovo & unidade & - & - & - & - & - \\
\hline Microtrator & unidade & 4 & 1,0 & 1,3 & 2,0 & 5,0 \\
\hline Misturador de raçâo & unidade & 12 & 1,0 & 1,0 & 1,0 & 12,0 \\
\hline Ordenhadeira mecanica & unidade & 7 & 1,0 & 1,0 & 1,0 & 7,0 \\
\hline Pulvertzador tratortzado & unidade & 134 & 1,0 & 1,3 & 6,0 & 177,0 \\
\hline Resfrlador de lelte, tanque expansăo & unidade & 4 & 1,0 & 1,0 & 1,0 & 4,0 \\
\hline Roçadeira costal & unidade & - & - & - & - & - \\
\hline Roçadelra tratorizada & unidade & - & - & - & - & - \\
\hline Semeadelra/adubadelra para plantlo convencional & unidade & 11 & 1,0 & 1,0 & 1,0 & 11,0 \\
\hline Semeadelra/plantadelra para plantio dreto & unidade & 7 & 1,0 & 1,0 & 1,0 & 7,0 \\
\hline Terraceador & unidade & 1 & 1,0 & 1,0 & 1,0 & 1,0 \\
\hline Trator de estelra & unidade & 6 & 1,0 & 1,0 & 1,0 & 6,0 \\
\hline Trator de pneus & unidade & 291 & 1,0 & 1,4 & 10,0 & 415,0 \\
\hline Açude ou represa & unidade & 489 & 1,0 & 1,9 & 13,0 & 919,0 \\
\hline Adega ou cantina & unidade & - & - & - & - & - \\
\hline Alambique & unidade & - & - & - & - & - \\
\hline Almoxarifadovoficina & unidade & 28 & 1,0 & 1,1 & 2,0 & 32,0 \\
\hline Armazem para grăos ensacados & sacas & 5 & 1,0 & 1,0 & 1,0 & 5,0 \\
\hline Balança para bovinos & unidade & 8 & 1,0 & 1,0 & 1,0 & 8,0 \\
\hline Balança para velculos & unidade & 3 & 1,0 & 1,0 & 1,0 & 3,0 \\
\hline Barraç̊o para bicho da seda/sirgarla & unidade & 1 & 1,0 & 1,0 & 1,0 & 1,0 \\
\hline Barracto para cuitivo de cogumelo & unidade & - & - & - & - & - \\
\hline Barraço para granja/anicultura & unidade & 9 & 1,0 & 1,3 & 3,0 & 12,0 \\
\hline Barraçaolgaipâlgaragem & unidade & 391 & 1,0 & 1,5 & 7,0 & 576,0 \\
\hline Blodigestor & unidade & - & - & - & - & - \\
\hline Casa de moradia habitada & unidade & 728 & 1,0 & 2,2 & 40,0 & $1.584,0$ \\
\hline Casa de moradia (total) & unidade & 754 & 1,0 & 2,4 & 40,0 & $1.776,0$ \\
\hline Curralmangueira & unidade & 253 & 1,0 & 1,1 & 3,0 & 278,0 \\
\hline Deposito/tulha & unidade & 470 & 1,0 & 1,6 & 10,0 & 774,0 \\
\hline Engenho & unidade & 10 & 1,0 & 1,2 & 3,0 & 12,0 \\
\hline Estabulo & unidade & 10 & 1,0 & 1,0 & 1,0 & 10,0 \\
\hline Estufa'plasticultura & $\mathrm{m} 2$ & 4 & 1,0 & $3.137,3$ & $12.000,0$ & $12.549,0$ \\
\hline Fabrica de farinha & unidade & 2 & 1,0 & 1,0 & 1,0 & 2,0 \\
\hline Fabrica de raçăo & unidade & 1 & 1,0 & 1,0 & 1,0 & 1,0 \\
\hline Instalaçðes para equinos & unidade & 3 & 1,0 & 9,0 & 25,0 & 27,0 \\
\hline
\end{tabular}

Fonte: Secretarla de Aaricultura e Abastecimento. CATUEA. Proleto LUPA 